SHIRLEY MINNELL FERREIRA DE OLIVEIRA

\title{
ESTUDO DO COMPORTAMENTO MECÂNICO DE MISTURAS DE FOSFOGESSO E CAL PARA UTILIZAÇÃO NA CONSTRUÇÃO RODOVIÁRIA
}

Dissertação apresentada à escola de Engenharia de São Carlos, da Universidade de São Paulo, como parte dos requisitos para a obtenção do Título de Mestre em Engenharia Civil - Área de concentração: Transportes.

Orientador: Prof. Dr. Alexandre Benetti Parreira

São Carlos

2005 


\section{DEDICATÓRIA}

$\mathcal{A}$ Deus, fonte de misericórdia, em quem sempre posso confiar!

Ao meu pai Antonio Belarmino de Oliveira, pelo incentivo, apoio, companheirismo e amore à minha mainha, Maria do Carmo Ferreira de Oliveira, um exemplo de vida, bondade e amor, uma mãe maravilhosa que sempre estará em meu coração!

Aos meus queridos e amados irmãos, Antonio Belarmino, Charles Elias e Maria Anunciada, pelo imenso amor e por toda dedicação e apoio em todos os momentos de minha vida.

Aos meus queridos sobrinhos e sobrinhas, Bruno, Henrique, Helena Cristina, Rayssa, Cibele e Rayanne, por compreenderem a minha ausência por esses anos em que foi realizado o mestrado.

Às minhas cunhadas, Cláudia e Heloisa, por tođo apóio e carinho. 


\section{AGRADECIMENTOS}

A Deus por abençoar e iluminar meu caminho;

À minha família, a quem dedico todo meu esforço, minha alegria de viver, os bons resultados do meu trabalho o carinho e incentivo ao longo de todas as conquistas de minha vida;

Aos meus amigos de Recife, minha terra querida, em especial a Ana, Ártemis, Carla, Carol, Erando, Gabriella, Gisele, Maria da Paz (in memoria), Tycianna, aos colegas e professores da UNICAP;

À CAPES, pelo apoio financeiro cedido durante a realização desta pesquisa;

Ao professor Alexandre Benetti Parreira, de quem tive todo apoio e orientação para a realização desta dissertação;

Aos professores do Departamento de Transportes da Escola de Engenharia de São Carlos - USP;

Aos meus colegas Eliana Fernandes, Hélio Marcos, Idalíria Moraes, Marta Pereira da Luz, Rogério Neto, Takeda e Weslley pela cooperação durante a realização dos ensaios e pelo compartilhamento de conhecimentos e experiências;

Aos funcionários do laboratório de Estradas e de Saneamento da EESC/USP, Gigante, Paulo, João e Júlio pela participação dedicada e prestativa na execução dos ensaios desta pesquisa;

A todos meus amigos e colegas de São Carlos e do Departamento de Transportes, em especial a Adson, Aline, Anthony, Carla Cristina, Cascia, Celane, Cheetara, Cida, Cira, Cláudio (marido da Zoró), Cynthya, DG, Daniele (Bananex), Fernando, Garibaldi, Geraldo, Giseli (Gi), Heliana, João Cristina, John Bahia, Jussara, Junior, Ka Kuerne, Lia (Zoró), Luciana, Lucimar, Marisa, Roberta, Rodrigo, Sérgio, Sílvia Melges, Silvia Cristina, Take a Shower, Tobias (pra casinha!), Vavá, ao Crisntina's sound, Anthony's movel, Cristina's car, Elza's móvel, Ártemis movel.

Enfim, a todos que contribuíram direta e indiretamente para a realização deste trabalho,

Muito obrigada. 


\section{SUMÁRIO}

LISTA DE FIGURAS

viii

LISTA DE TABELAS xiii

LISTA DE ABREVIATURAS E SIGLAS xvi

LISTA DE SÍMBOLOS xvii

RESUMO xix

ABSTRACT $\mathbf{x x}$

1 INTRODUÇÃO 1

1.1 CONSIDERAÇÕES INICIAIS 1

1.2 OBJETIVO 5

1.3 ORGANIZAÇÃO DO TRABALHO 5

2 REVISÃO BIBLIOGRÁFICA 7

2.1 CONSIDERAÇÕES SOBRE RESÍDUOS SÓLIDOS 7

2.1.1 Resíduos Sólidos: Definição e Classificação 7

2.1.2 Disposição Final dos Resíduos Sólidos 10

2.2 AS INDÚSTRIAS DE FERTILIZANTES FOSFATADOS 11

2.3 SUBPRODUTOS INDUSTRIAIS DO GESSO 12

2.4 FOSFOGESSO 14

2.4.1 Processo di-hidratado (DH). 16

2.4.2 Processo hemi-hidratado $(\mathrm{HH})$ 17

2.4.3 Processo hemi-di-hidratado $(\mathrm{HDH})$ 18

2.4.4 Processo anidro 19

2.4.5 Considerações complementares 20 
2.5 DISPOSIÇÃO DO FOSFOGESSO 21

2.6 CARACTERÍSTICAS FÍSICAS DO FOSFOGESSO__ 21

2.7 CARACTERÍSTICAS QUÍMICAS __ 24

2.8 CARACTERÍSTICAS MORFOLÓGICAS E MINERALÓGICAS DO FOSFOGESSO _ 29

2.9 CARACTERÍSTICAS RADIOLÓGICAS _ 30

2.10 APLICAÇÃO DO FOSFOGESSO _ _ 32

$2.10 .1 \mathrm{Na}$ agricultura __ 32

2.10.2 Na indústria química ___ 33

2.10.2.1 Indústria de cimento __ 33

2.10.2.2 Cargas minerais funcionais na indústria de papel ___ 34

2.10.2.3 Recuperação do enxofre __ 34

2.10.3 Na construção civil __ 35

2.10.3.1 Fabricação de painéis, placas e blocos ___ 35

2.10.3.2 Produção de gesso __ 36

2.10.3.3 Fabricação de agregado para concreto ___ 36

2.10.4 Na pavimentação _ 37

2.11 FOSFOGESSO COMPACTADO __ 37

2.12 MISTURAS CONTENDO FOSFOGESSO _ 41

2.12.1 Misturas de fosfogesso e cimento___ 41

2.12.2 Misturas de fosfogesso e solo___ 45

2.12.3 Misturas de Fosfogesso e cinza volante ___ 48

2.12.4 Fosfogesso e concreto compactado rolado _ 50

2.13 EXPANSIBILIDADE DE MISTURAS CONTENDO FOSFOGESSO ___ 53

$2.14 \mathrm{ACAL} \_54$

2.14.1 Origem Mineral __ 54

2.14.2 Rochas carbonatadas cálcio-magnesianas___ 54

2.14.3 Cal virgem _ 55

2.14.4 Cal hidratada__ 56

2.15 A CAL COMO ESTABILIZANTE _ 57

2.15.1 Efeitos da cal sobre as misturas __ 59

2.15.2 Materiais calcários estabilizados com a cal __ 61

3 MATERIAIS E MÉTODOS___ 62

3.1 INTRODUÇÃO__ 62

3.2 MATERIAIS _ 62 
3.2.1 Fosfogesso 62

3.2.1.1 Coleta e preparação___ 62

3.2.1.2 Determinação do $\mathrm{pH}$

3.2.1.3 Granulometria__ 64

3.2.1.4 Massa específica dos sólidos_ 64

3.2.1.5 Limites de Atterberg___ 65

3.2.2 A cal_ 65

3.3 COMPOSIÇÃO DAS MISTURAS _ 66

3.3.1 Estudo preliminar _ 66

3.3.2 Estudo definitivo _ 66

3.4 ENSAIOS DE COMPACTAÇÃO DAS MISTURAS __ 67

3.5 PROPRIEDADES MECÂNICAS DAS MISTURAS __ 67

3.5.1 Ensaio de compressão simples___ 68

3.5.1.1 Análise dos resultados _ 70

3.5.2 Ensaio de compressão diametral. __ 71

3.5.2.1 Análise dos resultados _ 74

3.5.3 Índice de Suporte Califórnia __ 75

3.5.3.1 Condição do ensaio__ 75

3.5.3.2 Análise dos resultados _ 76

3.6 LIXIVIÇÃO E SOLUBILIZAÇÃO__ 76

3.6.1 Análise dos resultados___ 81

3.7 ANÁLISE ESTATÍSTICA DOS RESULTADOS___ 81

3.7.1 Método para aceitação dos corpos de prova ___ 81

3.7.2 Análise de variância __ 82

4 APRESENTAÇÃO E ANÁLISE DOS RESULTADOS _ 84

4.1 INTRODUÇÃO __ 84

4.2 ANÁLISE DOS RESULTADOS DOS ENSAIOS DE COMPACTAÇÃO___ 84

4.3 PROPRIEDADES MECÂNICAS DAS MISTURAS ___ 87

4.3.1 Resistência à compressão simples___ 87

4.3.1.1 A influência do teor de cal ___ 89

4.3.1.2 A influência do tempo de cura_ 94

4.3.1.3 Relação entre resistência à compressão simples, o tempo de cura, e o teor de cal

4.3.2 Deformabilidade das misturas de fosfogesso e cal a partir dos ensaios de compressão simples

4.3.2.1 Influência do teor de cal

4.3.2.2 Influência do tempo de cura 
4.3.2.3 Relação entre $\mathrm{E}_{0}$, o tempo de cura e o teor de cal

4.3.3 Resistência à tração por compressão diametral

4.3.3.1 Influência do teor de cal

4.3.3.2 Influência do tempo de cura

4.3.3.3 Relação entre resistência à tração por compressão diametral, tempo de cura e teor de cal

4.3.4 Comparação das resistências à compressão simples e resistência à tração por compressão diametral 126

4.3.5 Envoltória de resistência de Mohr - Coulomb 129

4.3.6 Índice de Suporte Califórnia (CBR) 130

4.4 ANÁLISE DOS RESULTADOS DOS ENSAIOS DE LIXIVIAÇÃO, SOLUBILIZAÇÃO E ABSORÇÃO ATÔMICA

5 CONCLUSÕES E SUGESTÕES

5.1 CONSIDERAÇÕES INICIAIS

5.2 CONCLUSÕES

5.3 RECOMENDAÇÕES E SUGESTÕES PARA TRABALHOS FUTUROS 138

REFERÊNCIAS BIBLIOGRÁFICAS

ANEXO A

ANEXO B

ANEXO C

ANEXO D

ANEXO E

ANEXO F 


\section{LISTA DE FIGURAS}

FIGURA 2.1 - Diagrama representando as etapas do processo de obtenção do fosfogesso 15

FIGURA 2.2 - Curva de distribuição granulométrica do fosfogesso do estado de Louisiana

FIGURA 2.3 - Curvas granulométricas de dois fosfogesso

FIGURA 2.4- Distribuição granulométrica do agregado sintetizado pelo processo de obtenção do dióxido de enxofre do fosfogesso 36

FIGURA 2.5 - Comparação entre a resistência à compressão simples de fosfogesso estabilizado com $6 \%$ de cimento em função do tempo de cura e $\mathrm{pH}$

FIGURA 2.6 - Resistência à compressão simples para mistura de fosfogesso com os correspondentes teores de cinza volante

FIGURA 2.7 - Resistência à compressão simples x tempo de cura em semanas, das diferentes misturas composta de cal, cinza volante e fosfogesso di-hidratado

FIGURA 3.1 - Fosfogesso bruto do tipo di-hidratado após secagem e homogenização 63

FIGURA 3.2 - Distribuição granulométrica do fosfogesso 64

FIGURA 3.3 - Equipamento para moldagem dos corpos de prova de compressão simples (1) cilindro principal, (2) anéis complementares, (3) êmbolos espaçadores 69

FIGURA 3.4 - Ruptura dos corpos de prova de compressão simples 70

FIGURA 3.5 - Exemplo da estimativa de $E_{0}$ a partir da determinação do coeficiente "a", segundo o modelo hiperbólico proposto por DUNCAN \& CHANG (1970) 71

FIGURA 3.6 - Realização do ensaio de compressão diametral 73 
FIGURA 3.7- Equipamento utilizado para a realização do ensaio de compressão diametral

FIGURA 3.8 - Realização do ensaio do Índice de Suporte Califórnia 76

FIGURA 3.9 - Procedimento de agitação da mistura fosfogesso e cal e do fosfogesso puro, para o ensaio de lixiviação e solubilização 77

FIGURA 3.10-Filtragem da amostra em papel de filtro após agitação durante o ensaio de lixiviação e solubilização 78

FIGURA 3.11-Filtragem a vácuo das amostras através de membrana de fibra de vidro, para análise de metais 79

FIGURA 3.12-Ensaio de solubilização, amostra lacrada por um período de 7 dias 80

FIGURA 4.1- Curvas de compactação das misturas de fosfogesso e cal 85

FIGURA 4.2 - Massa específica seca máxima em função do teor de cal 86

FIGURA 4.3 - Umidade ótima em função do teor de cal 86

FIGURA 4.4 - Variação da resistência à compressão simples, para misturas de fosfogesso e cal ensaiadas sem imersão 90

FIGURA 4.5 - Variaçõa da resistência à compressão simples para misturas de fosfogesso e cal ensaiadas após imersão 90

FIGURA 4.6 - Diagrama de barras - variação da resistência à compressão simples para misturas de fosfogesso e cal ensaiadas sem imersão 91

FIGURA 4.7 - Diagrama de barras - variação da resistência à compressão simples para misturas de fosfogesso e cal ensaiadas após imersão 91

FIGURA 4.8 - Variação da resistência à compressão simples para misturas de fosfogesso e cal ensaiadas sem imersão 95

FIGURA 4.9 - Variação da resistência à compressão simples para misturas de fosfogesso e cal ensaiadas após imersão 95

FIGURA 4.10 - Diagrama de barras - variação da resistência à compressão simples para misturas de fosfogesso e cal ensaiadas sem imersão 
FIGURA 4.11 - Diagrama de barras - variação da resistência à compressão simples para misturas de fosfogesso e cal ensaiadas após imersão 96

FIGURA 4.12 - Valores de RCS: equação 4.1 "versus"laboratório 98

FIGURA 4.13 - Valores de RCS: equação 4.2 "versus"laboratório 98

FIGURA 4.14 - Variação da resistência à compressão simples com o tempo de cura e teor de cal - sem imersão 99

FIGURA 4.15 - Variação da resistência à compressão simples com o tempo de cura e teor de cal - após imersão 99

FIGURA 4.16 - Variação do módulo tangente inicial para misturas de fosfogesso e cal ensaiadas sem imersão 103

FIGURA 4.17 - Variação do módulo tangente inicial para as misturas de fosfogesso e cal ensaiadas após imersão 103

FIGURA 4.18 - Diagrama de barras - variação do módulo tangente inicial $\left(E_{0}\right)$ para misturas de fosfogesso e cal ensaiadas sem imersão 104

FIGURA 4.19 - Diagrama de barras - variação do módulo tangente inicial $\left(E_{0}\right)$ para misturas de fosfogesso e cal ensaiadas após imersão 104

FIGURA 4.20 - Variação do módulo tangente inicial para misturas de fosfogesso e cal ensaiadas sem imersão 106

FIGURA 4.21 - Variação do módulo tangente inicial para misturas de fosfogesso e cal ensaiadas após imersão 107

FIGURA 4.22 - Diagrama de barras - variação do módulo tangente inicial para misturas de fosfogesso e cal ensaiadas sem imersão 107

FIGURA 4.23 - Diagrama de barras - variação do módulo tangente inicial para as misturas de fosfogesso e cal ensaiadas após imersão 108

FIGURA 4.24 - Valores de $\mathrm{E}_{0}$ : equação 4.3 "versus"laboratório 110

FIGURA 4.25 - Valores de $E_{0}$ : equação 4.4 "versus"laboratório 110

FIGURA 4.26 - Variação da deformabilidade com o tempo de cura e teor de cal - sem imersão 111

FIGURA 4.27 - Variação da deformabilidade com o tempo de cura e teor de cal - após imersão 
FIGURA 4.28 - Variação da resistência à tração por compressão diametral para misturas de fosfogesso e cal ensaiadas sem imersão 115

FIGURA 4.29 - Variação da resistência à tração por compressão diametral para misturas de fosfogesso e cal ensaiadas após imersão 115

FIGURA 4.30 - Diagrama de barras - variação da resistência à tração por compressão diametral para misturas de fosfogesso e cal ensaiadas sem imersão 116

FIGURA 4.31 - Diagrama de barras - variação da resistência à tração por compressão diametral para misturas de fosfogesso e cal ensaiadas após imersão 116

FIGURA 4.32 - Variação da resistência à tração por compressão diametral para misturas de fosfogesso e cal ensaiadas sem imersão 120

FIGURA 4.33 - Variação da resistência à tração por compressão diametral para misturas de fosfogesso e cal ensaiadas após imersão 120

FIGURA 4.34 - Diagrama de barras - variação da resistência à tração por compressão diametral para misturas de fosfogesso e cal ensaiadas sem imersão 121

FIGURA 4.35 - Diagrama de barras - variação da resistência à tração por compressão diametral para misturas de fosfogesso e cal ensaiadas após imersão 121

FIGURA 4.36 - Valores de RCD: equação 4.5 "versus"laboratório 124

FIGURA 4.37 - Valores de RCD: equação 4.6 "versus"laboratório 124

FIGURA 4.38 - Variação da resistência à tração por compressão diametral com o tempo de cura e teor de cal - sem imersão

FIGURA 4.39 - Variação da resistência à tração por compressão diametral com o tempo de cura e teor de cal - após imersão 125 
FIGURA 4.40 - Variação relativa das (RCS) e (RCD) em função do teor de cal para misturas ensaiadas sem imersão e após imersão para o tempo de cura imadiato

FIGURA 4.41 - Variação relativa (RCS) e (RCD) em função do teor de cal para misturas ensaiadas sem imersão e com imersão para o período de cura de 3 dias

FIGURA 4.42 - Variação relativa das (RCS) e (RCD) em função do teor de cal para misturas ensaiadas sem imersão e com imersão, para 7 dias de cura

Figura 4.43 - Variação relativa das (RCS) e (RCD) em função do teor de cal para misturas ensaiadas sem imersão e com imersão, para 28 dias de 128

Figura 4.44 - Índice de Suporte Califórnia em função do teor de cal para misturas de fosfogesso e cal

Figura 4.45 - Expansão das misturas de fosfogesso e cal em função do teor de cal 


\section{LISTA DE TABELAS}

TABELA 2.1 - Composição do fosfogesso do tipo di-hidratado (DH) fonte Chang e Mantell, (1990)

TABELA 2.2 - Composição do fosfogesso do tipo di-hidratado (DH), fonte Chang e Mantell, (1990) \& Kouloheris, (1980) 18

TABELA 2.3 - Composição do fosfogesso do tipo hemi-di-hidratado $(\mathrm{HH})$ 19

TABELA 2.4 - Resultados de análises físicas de fosfogessos di-hidratados advindos de três estados norte-americanos (TAHA \& SEALS, 1991) 22

TABELA 2.5 - Resultados das análises físicas do fosfogesso. Fonte Taha, Seals, Tittlebaum e Saylak 22

TABELA 2.6 - Composição do fosfogesso estudado por Trichês \& Maccarini, 1988, produzido em Santa Catarina 25

TABELA 2.7 - Análise do fosfogesso realizada por Freitas, (1992) 25

TABELA 2.8 - Composição do fosfogesso estudado por Kobayashi, (IPT, 2000a) 25

TABELA 2.9 - Composição química típica dos fosfogesso di-hidratado encontrados na Turquia (ERDEM \& ÖLMEZ, 1989), nos estados norte-americanos de Louisiana, Texas e Florida (TAHA \& SEALS, 1991) e na Jordânia (MOHAMMAD et al., 1999) 26

TABELA 2.10 - Composição química do fosfogesso di-hidratado e anidro. Fonte Singh, 1990. 26

TABELA 2.11 - Concentrações típicas de traços de elementos no fosfogesso do estado de Luisiana. Fonte: TAHA et al. (1995). 
TABELA 2.12 - concentrações de traços de elementos presentes no fosfogesso do "Freeport-McMoran, Inc" (TAHA et al., 1992). 28

TABELA 2.13 - $\rho_{\text {dmáx }}$ e $\omega_{0}$ de fosfogessos di-hidratados produzidos na Florida (EUA), obtidas dos ensaios de compactação Proctor normal e Proctor modificado (adaptado de CHANG \& MANTELL, 1990) 39

TABELA 2.14 - Resistência à compressão simples fonte, (Gerrity et al., 1994) 44

TABELA 2.15 - Variação do teor de fosfogesso di-hidratado, solo e CR-70, FIGUEROA et al. (1987). 47

TABELA 2.16 - Proporções de Mistura de fosfogesso com concreto rolado compactado utilizadas no campo experimental para projeto de pavimento, Taha \& Seals (1991) 51

TABELA 2.17 - Propriedades mecânicas de laboratório e de campo das misturas de concreto compactado rolado Taha \& Seals (1991) 52

TABELA 2.18 - Propriedades mecânicas de laboratório e de campo das misturas de concreto compactado rolado Taha \& Seals (1991) 54

TABELA 3.1 - Características da cal cálcica, Supercal CH-III 65

TABELA 3.2 - Misturas ensaiadas com os respectivos teores de cal 66

TABELA 4.1 - Massa específica seca máxima e umidade ótima das misturas de fosfogesso e cal 84

TABELA 4.2 - Resistência à compressão simples e sua variação 89

TABELA 4.3 - Resistência à compressão simples de misturas de solo e cal e fosfogesso e cal 93

TABEIA 4.4 - Resistência à compressão simples de misturas de fosfogesso e cal e fosfogeso e cimento

TABELA 4.5 - Influência das variáveisdo estudo sobre os resultados de RCS _ 100

TABELA 4.6 - Módulo tangente inicial e sua variação 102

TABELA 4.7 - Módulo tangente inicial de misturas de fosfogesso e cal, e fosfogesso e cimento 105

TABELA 4. 8 - Influência das variáveis do estudo sobre os resultados do $\left(E_{0}\right)_{-} 112$ TABELA 4.9 - Resistência àtração por compressão diamtral e sua variação 
TABELA 4.10 - Resistência à tração por compressão diametral de misturas de solo e cal, e fosfogesso e cal

TABELA 4.11 - Resistência à tração por compressão diametral de misturas de fosfogesso e cal, e fosfogesso e cimento 119

TABELA 4.12 - Influência das variáveis do estudo sobre os resultados da (RCD) 126

TABELA 4.13 - Variação da coesão e ângulo de atrito interno com o teor de cal e tempo de cura - sem imersão

TABELA 4.14 - Variação da coesão e ângulo de atrito interno com o teor de cal e tempo de cura - após imersão

TABELA 4.15 - Valores de c e $\phi$ de misturas de solo e cal e fosfogesso e cal

TABELA 4.16 - Valores de CBR e expansão para o fosfogesso puro e para as misturas de fosfogesso e cal

TABELA 4.17 - Influência das variáveis do estudo sobre o ensaio de CBR

TABELA 4.18 - Análise das impurezas obtidas de amostras soltas e compactadas de fosfogesso puro 


\section{LISTA DE ABREVIATURAS E SIGLAS}

\begin{tabular}{|c|c|}
\hline $\mathrm{ABCP}$ & Associação Brasileira de Cimento Portland \\
\hline ABNT & Associação Brasileira de Normas Técnicas \\
\hline ASTM & American Society for Testing and Materials \\
\hline CBR & Índice de Suporte de Califórnia \\
\hline CNEN & Comissão Nacional de Energia Nuclear \\
\hline $\mathrm{Cl}$ & Curie \\
\hline DER-SP & Departamento de Estradas de Rodagem de São Paulo \\
\hline DNER & Departamento Nacional de Estradas de Rodagem \\
\hline EESC-USP & Escola de Engenharia de São Carlos - Universidade de São Paulo \\
\hline EUA & Estados Unidos da América \\
\hline FIPR & Florida Institute of Phosphate Research \\
\hline GO & Estado de Goiás \\
\hline IBRAFOS & Instituto Brasileiro de Fosfato \\
\hline IPEN & Instituto de Pesquisas em Energia Nuclear \\
\hline IPT & Instituto de Pesquisas Tecnológicas \\
\hline MG & Estado de Minas Gerais \\
\hline NBR & Norma Brasileira Registrada \\
\hline ppm & Parte por milímetro \\
\hline RCS & Resistência à compressão simples \\
\hline $\mathrm{RCD}$ & Resistência à compressão Diametral \\
\hline S.D & Sem data \\
\hline S.I. & Sistema Internacional \\
\hline SP & Estado de São Paulo \\
\hline STT & Sistema de Transporte e Topografia \\
\hline TRB & Transportation Research Board \\
\hline USP & Universidade de São Paulo \\
\hline
\end{tabular}




\section{LISTA DE SÍMBOLOS}

\begin{tabular}{|c|c|}
\hline$\phi$ & Ângulo de atrito interno \\
\hline$\rho_{\text {dmáx }}$ & Massa específica seca máxima \\
\hline$\rho_{\mathrm{s}}$ & Massa específica dos sólidos \\
\hline s & Desvio padrão \\
\hline $\mathrm{Ag}$ & Prata \\
\hline $\mathrm{Al}_{2} \mathrm{O}_{3}$ & Óxido de alumínio \\
\hline As & Arsênio \\
\hline $\mathrm{Ba}$ & Bário \\
\hline${ }^{214} \mathrm{Bi}$ & Berílio-214 \\
\hline C & Coesão \\
\hline $\mathrm{C}^{14}$ & Carbono-14 \\
\hline $\mathrm{CaO}$ & Óxido de cálcio \\
\hline $\mathrm{CaSO}_{4}$ & Sulfato de Cálcio \\
\hline $\mathrm{Cd}$ & Cádmio \\
\hline $\mathrm{CO}_{2}$ & Óxido de carbônico \\
\hline CP II-E32 & Cimento Portland composto com escória \\
\hline CP V ARI & Cimento Portland de alta resistência inicia \\
\hline c.p. & corpo de prova \\
\hline $\mathrm{Cr}$ & Cromo \\
\hline $\mathrm{Cr}-\mathrm{VI}$ & Cromo-VI \\
\hline$d$ & Diâmetro \\
\hline $\mathrm{E}_{0}$ & Módulo tangente inicial \\
\hline eq. & Equação \\
\hline $\mathrm{Fe}$ & Ferro \\
\hline $\mathrm{Fe}_{2} \mathrm{O}_{3}$ & Óxido férrico \\
\hline $\mathrm{h}$ & Altura \\
\hline $\mathrm{H}_{2} \mathrm{O}$ & Água \\
\hline $\mathrm{H}_{2} \mathrm{SO}_{4}$ & Ácido sulfúrico \\
\hline $\mathrm{H}_{3} \mathrm{PO}_{4}$ & Ácido fosfórico \\
\hline $\mathrm{HF}$ & Ácido fluorídrico \\
\hline $\mathrm{Hg}$ & Mercúrio \\
\hline IP & Índice de plasticidade \\
\hline $\mathrm{K}_{2} \mathrm{O}$ & Óxido de potássio \\
\hline $\mathrm{Mg}$ & Magnésio \\
\hline $\mathrm{MgO}$ & Óxido de magnésio \\
\hline $\mathrm{Mn}$ & Manganês \\
\hline $\mathrm{MPa}$ & Mega-Pascal \\
\hline MR & Módulo de Resiliência \\
\hline $\mathrm{N}$ & Newton \\
\hline$n$ & $\begin{array}{l}\text { Número de moléculas de água presente na composição do } \\
\text { fosfogesso }\end{array}$ \\
\hline n.d. & Não detectado \\
\hline $\mathrm{Na}_{2} \mathrm{O}$ & Óxido de sódio \\
\hline
\end{tabular}




\begin{tabular}{|c|c|}
\hline $\mathrm{NaOH}$ & Hidróxido de sódio \\
\hline$n^{-}$ & Número \\
\hline$P$ & Fósforo \\
\hline p.p.m. & Parte por milhão \\
\hline $\mathrm{P}_{2} \mathrm{O}_{5}$ & Anidrido fosfórico ou óxido de fósforo 5 \\
\hline $\mathrm{P}_{4} \mathrm{O}_{10}$ & Óxido de fósforo \\
\hline $\mathrm{Pb}$ & Chumbo \\
\hline${ }^{210} \mathrm{~Pb}$ & Chumbo-210 \\
\hline${ }^{214} \mathrm{~Pb}$ & Chumbo-214 \\
\hline $\mathrm{pCi} / \mathrm{g}$ & Pico Curie por grama \\
\hline PF & Perda ao fogo \\
\hline $\mathrm{pH}$ & Concentração hidrogeniônica \\
\hline $\mathrm{Pl}$ & Proctor intermediário \\
\hline PM & Proctor modificado \\
\hline PN & Proctor normal \\
\hline${ }^{210} \mathrm{Po}$ & Polônio-210 \\
\hline${ }^{214} \mathrm{Po}$ & Polônio-214 \\
\hline${ }^{218} \mathrm{Po}$ & Polônio-218 \\
\hline${ }^{226} \mathrm{Ra}$ & Rádio-226 \\
\hline${ }^{228} \mathrm{Ra}$ & Rádio-228 \\
\hline $\mathrm{RI}$ & Resíduo insolúvel \\
\hline${ }^{222} \mathrm{Rn}$ & Radônio-222 \\
\hline$S^{-2}$ & íon sulfeto \\
\hline Se & Selênio \\
\hline $\mathrm{SiO}_{2}$ & Sílica ou óxido de silíciio \\
\hline t/a & Toneladas por ano \\
\hline${ }^{228} \mathrm{Th}$ & Tório-228 \\
\hline${ }^{230} \mathrm{Th}$ & Tório-230 \\
\hline${ }^{232} \mathrm{Th}$ & Tório-232 \\
\hline $\mathrm{U}_{3} \mathrm{O}_{8}$ & Óxido de Urânio \\
\hline${ }^{234} U$ & Urânio-234 \\
\hline${ }^{235} \mathrm{U}$ & Urânio-235 \\
\hline${ }^{238} \mathrm{U}$ & Urânio-238 \\
\hline w & Umidade do corpo de prova \\
\hline$\omega_{\circ}$ & Umidade ótima \\
\hline $\mathrm{Zn}$ & Zinco \\
\hline${ }^{0} \mathrm{C}$ & Grau Celsius \\
\hline${ }^{0} \mathrm{~F}$ & Grau Fahrenheit \\
\hline $\mathrm{Ca}(\mathrm{OH})_{2}$ & hidróxido de Cálcio \\
\hline $\mathrm{Ca}_{10}\left(\mathrm{PO}_{4}\right)_{6} \mathrm{~F}_{2}$ & Fluorapatita \\
\hline
\end{tabular}




\section{RESUMO}

OLIVEIRA, S. M. F. (2005). Estudo do comportamento mecânico de misturas de fosfogesso e cal para utilização na construção rodoviária. São Carlos 2005.190p. Dissertação de Mestrado. Escola de Engenharia de São Carlos, Universidade de São Paulo, São Carlos, 2005.

Este trabalho tem como objetivo estudar, a partir de ensaios de laboratório, o comportamento mecânico de misturas de fosfogesso e cal destinadas à construções de bases e sub-bases rodoviárias. O fosfogesso é um resíduo resultante da produção do ácido fosfórico, principal componente de fertilizantes fosfatados. O fosfogesso é gerado em grande escala, originando sérios problemas de armazenagem. Restrições de leis ambientais e o aumento do custo de espaço para a armazenagem do fosfogesso têm estimulado pesquisas para a aplicação desse material. Entre as pesquisas, encontra-se, o aproveitamento desse resíduo como material de construção de bases e sub-bases rodoviárias. As amostras destas misturas foram submetidas a ensaios de compressão simples, compressão diametral e CBR. Nos ensaios de compressão simples e compressão diametral, os copos de prova foram ensaiados sem imersão e após imersão prévia em água por quatro horas. Para todos os teores de cal utilizados ( $0 \%, 3 \%, 5 \%, 7 \%$ e $10 \%)$ os corpos-de-prova foram compactados na energia equivalente ao Proctor modificado. Para cada teor de cal os corpos-de-prova passaram por processo de cura de 0, 3, 7 e 28 dias. Quatro réplicas foram moldadas para cada condição de ensaio, obtendo-se a média dos resultados pelo método estatístico de GRUBBS. Concluiu-se com esses ensaios que valores crescentes de tempo de cura e de teor de cal conduziram a maiores valores de resistência e de rigidez. Além disso, ensaios realizados após a imersão em água apresentaram valores de resistência à compressão simples, resistência à compressão diametral e rigidez menores do que os obtidos sem imersão. Observou-se também que as misturas de fosfogesso e cal, no geral, apresentaram melhores resultados de resistência à compressão simples, resistência à compressão diametral e coesão do que as misturas de solo cal. Entretanto as misturas compostas por fosfogesso e cimento obtiveram valores superiores de resistência e rigidez se comparada com as misturas de fosfogesso e cal.

Palavras-chave: fosfogesso, Misturas estabilizadas com cal, pavimento, reciclagem. 


\section{ABSTRACT}

OLIVEIRA, S. M. F. (2005). Mechanical Behavior Study of mixtures of phosphogypsum and lime to road construction utilization. São Carlos 2005 190p. - Dissertation of Master. Escola de Engenharia de São Carlos, Universidade de São Paulo, São Carlos, 2005.

This work has the aim of study, considering laboratory experiments, the mechanical behavior of a mixture of phosphogypsum and lime to be used in bases and sub-bases of road construction. The phosphogypsum is a solid waste result of the phosphoric acid production, main component of phosphor fertilizers. The phosphogypsum is generated in large scale, causing serious problems of storage. Restriction of environment laws and the increasing cost of the area needed for the phosphogypsum storage have stimulated researches to this material application. Among these researches, there is the reutilization of this waste as construction material of road bases and sub-bases. The samples of theses mixtures were submitted to tests of unconfined compressive strength, indirect tensile strength and California Bearing Ratio. In the tests of unconfined compressive strength and indirect tensile strength, the specimens were submitted to two test conditions: without immersion and with immersion in water for four hours. It was used $0 \%, 3 \%, 5 \%, 7 \%$ e $10 \%$ of lime in the mixtures. All specimens were compacted in the energy modified Proctor. Each specimens get through to a process of curing time of the $0,3,7$ and 28 days. For each condition test 4 copies were molded and the result got by the statistic method of GRUBBS. With this tests, it was concluded that higher values of time of cure and the line content led to higher strength and stiffness values. Besides, test performed after immersion in water presented strength values for the unconfined compressive, diametral compression strength and stiffness lower than those obtained without immersion. It also can be observed that phosphogypsum and lime mixtures got better results of unconfined compressive strength and diametral compression strength than soil and lime mixtures. However, phosphogypsum and cement mixtures got better results of strength and stiffness than phosphogypsum and lime mixtures.

Key-words: phosphogypsum, lime-Treated Mixtures, pavement, recycling. 


\section{INTRODUÇÃO}

\subsection{CONSIDERAÇÕES INICIAIS}

As atividades humanas têm como conseqüência a produção de diversos tipos de resíduos que, dispostos de forma inadequada, podem provocar problemas de ordem ambiental e de saúde pública. O crescimento populacional e industrial tem levado ao incremento da geração desses materiais, o qual pode afetar muito negativamente o meio ambiente em que vivemos.

Os resíduos industriais merecem atenção especial quanto ao seu tratamento e sua disposição, pois, a sua maioria contém componentes prejudiciais ao meio ambiente. Assim, a disposição de resíduos industriais em aterros sanitários, a céu aberto ou descartados em lagos, rios e mares pode provocar prejuízos ao equilíbrio da natureza e também perdas econômicas.

A reciclagem de resíduos industriais visa evitar possíveis impactos ambientais decorrentes de seu descarte e reduzir os custos de gerenciamento e manutenção das áreas de deposição. Na indústria da construção civil, a reciclagem também possibilita a substituição e minimiza a exploração de grandes quantidades de recursos naturais. Embora o uso de resíduos na construção civil seja estudado há algum tempo, nos últimos anos tem crescido o interesse pela aplicação desses materiais. Esse interesse deve-se à soma de razões ecológicas, econômicas e tecnológicas.

Dentre os resíduos industriais, destaca-se o fosfogesso, que é gerado pelas indústrias de fertilizantes fosfatados através do ataque da rocha fosfática com ácido sulfúrico, para a produção do ácido fosfórico. O fosfogesso é um sulfato de cálcio hidratado, com diferentes graus de hidratação, variando de anidro a di-hidratado. A composição do fosfogesso em seu estado bruto apresenta concentrações de radionuclídeos originados das séries naturais do urânio ( $\left.{ }^{226} \mathrm{Ra},{ }^{210} \mathrm{Po},{ }^{210} \mathrm{~Pb},{ }^{230} \mathrm{Th},{ }^{234} \mathrm{U},{ }^{235} \mathrm{U},{ }^{238} \mathrm{U}\right)$, das séries naturais do 
tório ( ${ }^{228} \mathrm{Th},{ }^{228} \mathrm{Ra},{ }^{232} \mathrm{Th}$ ), urânio-238, rádio-226 e radônio-222, ácidos livres e traços de metais pesados, dentre outras impurezas presentes em sua composição química (BARNETT, 1999).

Para a produção de 1 tonelada de ácido fosfórico são necessárias 3,1 toneladas de rocha fosfática e 2,6 toneladas de ácido sulfúrico (VALERY, 1991). Para cada tonelada de ácido fosfórico produzida, resultam cerca de 4,5 toneladas de fosfogesso. Esse valor é muito expressivo e pode variar com a composição da rocha fosfática (FREITAS, 1992; VALERY, 1991; DAMASCENO, 1994). Segundo dados do IBRAFOS, no Brasil, produziu-se 1.785.000 toneladas de fosfogesso em 2001.

A destinação final do fosfogesso pode ser realizada através de sua deposição em grandes áreas a céu aberto próximas às fábricas, ou através de seu descarte em rios e oceanos. A maneira de disposição adotada depende da disponibilidade e do custo de áreas nas proximidades da indústria geradora. A legislação ambiental tem aplicado um rígido controle sobre as áreas de deposição de resíduos, originando uma crescente pressão fiscalizadora sobre as indústrias geradoras desses materiais (FREITAS, 1992; BARTL \& ALBUQUERQUE, 1992).

O manuseio e a disposição inadequados do fosfogesso podem provocar sérios riscos ao meio ambiente, tais como: contaminações de mananciais de água, do solo superficial e do subsolo, ocasionadas pela lixiviação dos metais pesados e de substâncias ácidas provenientes do material. Os efeitos causados pelas suas partículas radioativas, esses ainda não foram plenamente avaliados.

Os problemas decorrentes do aumento da produção de fertilizantes e conseqüentemente da quantidade de resíduos armazenados devem ser analisados e solucionados. Uma das alternativas é a sua aplicação na área agrícola como fonte de cálcio, principalmente para solos tropicais e subtropicais; ou ainda, como fonte de enxofre para solos que apresentam ausência desse nutriente. $O$ fosfogesso também pode ser utilizado como redutor de alcalinidade e salinidade em solos salinos ou com alto teor de sódio, resultando na melhoria de culturas e qualidade de frutas (SILVA, 1997). 
$\mathrm{Na}$ indústria cimenteira, o fosfogesso é utilizado como retardador de pega. $\mathrm{Na}$ construção civil, placas, painéis, tijolos e ladrilhos podem ser confeccionados a partir desse material. E ainda, na área de pavimentação, é possível a sua aplicação na construção de bases, sub-bases e aterros rodoviários. Essa última aplicação tem a vantagem de associar a possibilidade da utilização de grandes quantidades do resíduo à substituição da exploração de recursos naturais.

No entanto, o aproveitamento do fosfogesso é ainda muito limitado em relação à quantidade produzida, constituindo-se em importante tema para novas investigações tecnológicas (ABREU, 1992; BARLT et al., 1992).

Estudos sobre a potencialidade do emprego do fosfogesso como material para construção de bases e sub-bases de pavimentos foram realizados no Brasil por Maccarini (1991), que analisou as propriedades mecânicas do fosfogesso compactado. Na Escola de Engenharia de São Carlos - USP, Ortiz (1997) estudou a resistência de misturas compactadas compostas de fosfogesso anidro e solo. Em seguida, Takeda (1998) avaliou as propriedades mecânicas de misturas de fosfogesso di-hidratado estabilizado com cimento. Ainda para esta mesma mistura, Kobayashi (2000) e Silvestre (2002), determinaram, respectivamente, a influência do tipo de cimento utilizado na estabilização do fosfogesso, na expansibilidade e resistência da mesma. Finalmente, Parente (2002) analisou o comportamento mecânico dessa mistura quando submetida a ensaios triaxiais cíclicos.

Os estudos concluíram que, apesar do fosfogesso di-hidratado compactado apresentar baixa resistência mecânica e instabilidade frente à ação da água, se ao mesmo for adicionado algum agente estabilizante, de maneira a induzir uma cimentação de suas partículas, o material resultante oferece boas condições de resistência, rigidez e durabilidade.

Como já destacado, o fosfogesso, como muitos outros resíduos, não pode ser empregado sozinho devido à sua baixa capacidade de suporte. Entretanto, segundo Lahtinen (2001), misturas desses resíduos com estabilizantes, como a cal ou cimento podem resultar num material adequado, que apresente propriedades vantajosas como as seguintes: 
- resistência à deformação;

- boa capacidade contra congelamento;

- boa capacidade de retenção de água;

- baixo peso;

- boa capacidade de suporte;

- trabalhável e fácil de construir.

A cal hidratada tem sido amplamente estudada pelos efeitos favoráveis que tem no comportamento de solos com altos teores de finos. Quando se adiciona cal a uma mistura ocorrem várias reações, entre as quais podemos considerar:

- A permuta iônica e floculação, na qual verifica-se uma diminuição da plasticidade devido à troca iônica os cátions $\mathrm{Ca}^{++}$(produzidos devido à adição de cal) vão adsorver-se à superfície das partículas, diminuindo sua eletronegatividade, originando floculação (aglomeração das partículas) e produzindo uma imediata melhora na plasticidade, trabalhabilidade e resistência sem cura;

- A reação pozolânica, que é uma reação lenta que se produz em meios de $\mathrm{pH}$ elevado, onde a solubilidade da sílica e alumina são incrementadas e combinam-se com $\mathrm{Ca}^{++}$para formar silicato de cálcio, melhorando a resistência da mistura compactada e sua estabilidade;

- A carbonatação, que é a combinação de óxido ou hidróxido de cálcio com anidrido carbônico presente nas minúsculas bolhas de ar, absorvidas na mistura do solo com a cal. A reação tende a refazer o carbonato original, visto que a decomposição desse composto pelo calor é uma reação reversível. Desse fato resulta a ação cimentante da cal, porque ela faz aparecer um novo corpo sólido que trava e firma as partículas do solo (GUIMARÃES, 1971).

Resultados de pesquisas têm sido divulgados destacando a melhoria do comportamento de materiais calcários quando a cal hidratada é incorporada 
aos mesmos. A resistência da mistura resultante é aumentada em decorrência da cal fornecer íons de $\mathrm{Ca}^{++}$solúveis o que proporciona a cimentação dos carbonatos (GRAVES, 1987).

\subsection{OBJETIVO}

O principal objetivo desta pesquisa é determinar, a partir de ensaios de laboratório, o comportamento mecânico de misturas de fosfogesso e cal.

Para se alcançar o objetivo proposto, misturas de fosfogesso e cal foram submetidas a ensaios de compressão simples, compressão diametral e CBR, para a obtenção da resistência à compressão simples, rigidez, resistência à tração por compressão diametral, coesão, ângulo de atrito interno, índice de suporte Califórnia e expansão do material. Foram avaliadas a influência das condições de ensaio, ou seja, sem imersão e após imersão prévia em água por um período de 4 horas, tempo de cura e porcentagem de cal. Para cada ensaio e condições analisadas, foram moldados 4 corpos-de-prova, de maneira a permitir a análise estatística dos resultados.

Destaca-se também a comparação do comportamento mecânico das misturas de fosfogesso e cal com o das misturas de fosfogesso e cimento e solo cal determinado em pesquisas anteriores.

\subsection{ORGANIZAÇÃO DO TRABALHO}

Este texto foi elaborado na forma de dissertação como parte dos requisitos exigidos para a obtenção do título de Mestre em Transportes, estando dividido em 5 capítulos.

O capítulo 1 apresenta a importância do aproveitamento de resíduos sólidos na construção civil, bem como o objetivo a que se destina esta pesquisa.

O capítulo 2 apresenta a revisão bibliográfica. Nesta etapa procurouse abordar principalmente aspectos relacionados à pesquisa, afim de auxiliar na análise dos resultados.

O capítulo 3 descreve a caracterização dos materiais utilizados na pesquisa, os procedimentos observados nos ensaios laboratoriais e o 
processo de análise dos resultados. O capítulo 4 apresenta a análise dos resultados obtidos.

Finalmente, o capítulo 5 aborda as principais conclusões obtidas e sugestões para trabalhos futuros. 


\section{REVISÃO BIBLIOGRÁFICA}

\subsection{CONSIDERAÇÕES SOBRE RESÍDUOS SÓLIDOS}

\subsubsection{Resíduos Sólidos: Definição e Classificação}

RESÍDUOS SÓLIDOS, de acordo com a norma NBR 10.004 (RESÍDUOS SÓLIDOS - DEFINIÇÃO E CLASSIFICAÇÃO), são sobras de determinadas substâncias que se encontram no estado sólido e semi-sólido, que resultam de atividades da comunidade tais como: industrial, doméstica, hospitalar, comercial, agrícola, de serviços de varrição, como também lodos provenientes de sistemas de tratamento de água, aqueles gerados em equipamentos e instalações de controle de poluição, bem como de determinados líquidos cujas particularidades tornem inviável o seu lançamento na rede pública de esgotos, ou exijam, para isso, saída técnica e economicamente inviabilizada em face à tecnologia disponível.

De acordo com sua origem, os resíduos sólidos são classificados como: doméstico ou residencial, industriais, resíduos de serviço de saúde, resíduos de portos, aeroportos, terminais rodoviários e ferroviários, resíduos agrícolas, entulho de obras, resíduos radioativos (lixo atômico).

Todos esses resíduos podem ser classificados, segundo a nova norma da ABNT NBR 10.004 como:

Resíduos classe I (perigosos): pelas suas características de inflamabilidade, corrosividade, reatividade, toxidade e patogenicidade, podem apresentar riscos à saúde pública, provocando ou contribuindo para o aumento da mortalidade ou ainda efeitos adversos ao meio ambiente, quando manuseados ou dispostos de forma inadequada.

Resíduos Classe II A (não perigosos/não inertes): aqueles que não se enquadram nas classificações de resíduos classe I - Perigosos ou de resíduos 
classe II B - Inertes, nos termos desta norma. Os resíduos classe II A podem ter propriedades, tais como: biodegradabilidade, combustibilidade ou solubilidade em água.

Resíduos Classe II B (não perigosos/inertes): quaisquer resíduos que, quando amostrados de uma forma representativa, segundo a ABNT NBR 10.007, e submetidos a um contato dinâmico e estático com água destilada ou desionizada, à temperatura ambiente, conforme ABNT NBR 10.006, não tiverem nenhum de seus constituintes solubilizados a concentrações superiores aos padrões de potabilidade de água, excetuando-se aspecto, cor, turbidez, dureza e sabor. Como exemplo destes materiais, pode-se citar rochas, tijolos, vidros e certos plásticos e borrachas que não são decompostos prontamente.

Essa classificação baseia-se na presença de certas substâncias perigosas, relacionadas na norma, e em testes laboratoriais complementares, nos quais vários parâmetros químicos são analisados nos extratos lixiviados e solubilizados dos resíduos.

Portanto, para a classificação de um resíduo são necessários os ensaios de lixiviação e solubilização (NBR 10.005 e NBR 10.006, respectivamente), após a utilização da NBR 10.004 (CLASSIFICAÇÃO DE RESÍDUOS).

Lixiviação é a operação de deslocamento ou arraste por meio líquido de certas substâncias contidas nos resíduos sólidos (CETESB, 1993).

Outros termos muito utilizados no estudo dos aterros sanitários são: chorume, percolado, impermeabilização, dentre outros. Estes itens são definidos a seguir.

Chorume ou sumeiro é um líquido produzido pela decomposição da matéria orgânica, disposta em aterros sanitários, que tem como características a cor negra, ou mau cheiro e a elevada DBO (Demanda Bioquímica de Oxigênio) (CETESB, 1993).

Percolado é o líquido que passa através de um meio poroso, para filtração ou extração de substâncias desse meio. Em um aterro sanitário, o percolado compreende geralmente o sumeiro diluído em águas percoladas em massas de resíduos e materiais lixiviados (CETESB, 1993). 
A CETESB (1993) divide os resíduos sólidos em três categorias: sólidos industriais, semi-sólidos e sólidos urbanos, os quais estão definidos a seguir.

- Resíduos sólidos industriais: são os resíduos sólidos e semi-sólidos resultantes do processamento industrial, assim como determinados resíduos líquidos oriundos do mesmo processamento que, por suas características peculiares, não podem ser lançados na rede de esgoto ou em corpos de água e não são passíveis de tratamento pelos métodos convencionais. Incluem-se também os lodos provenientes das estações de tratamento de efluentes. A eliminação dos resíduos sólidos de origem industrial é problemática, considerando-se sua composição físicoquímica e a grande quantidade gerada diariamente.

- Resíduos semi-sólidos: materiais, produtos e substâncias resultantes dos processos industriais e de estações de tratamentos de efluentes que não são passíveis de reaproveitamento e apresentam características semi-sólidas;

- Resíduos sólidos urbanos: são todos os resíduos sólidos produzidos em edificações residenciais, em estabelecimentos públicos e do comércio em geral, assim como aqueles resultantes das diversas atividades de limpeza urbana. Excluem-se os resíduos sólidos industriais, conforme definidos acima, os resíduos produzidos em estabelecimentos hospitalares, portos e aeroportos que, por suas características peculiares e conforme legislação vigente exige cuidados especiais quanto ao acondicionamento, coleta e disposição final.

A reciclagem, ou seja, o retorno ao consumo dos materiais que ainda possuem algum valor agregado, é o mais indicado, podendo ser realizado de quatro formas básicas: reciclagem primária, secundária, terciária e quaternária.

- Reciclagem primária: é a recuperação de uma matéria-prima dentro do próprio processo de produção, dentro ou fora da indústria geradora de refugo;

- A reciclagem secundária: ocorre na recuperação dos resíduos sólidos urbanos, em que vários materiais estão misturados e necessitam de separação prévia, total ou parcial, para readmissão ao ciclo de consumo. 
- A reciclagem terciária: refere-se à despolimerização e/ou decomposição e reutilização dos monômeros e oligômeros formados a partir do refugo plástico.

- A reciclagem quaternária: consiste na recuperação da alta quantidade de energia química gasta na produção do material plástico, estocada sob a forma de ligações químicas. O material é incinerado e a energia liberada é utilizada para geração de calor, vapor e energia elétrica;

\subsubsection{Disposição Final dos Resíduos Sólidos}

Os aterros industriais podem ser classificados como I, II, (II A e II B), conforme a periculosidade dos resíduos a serem dispostos, ou seja, os aterros Classe I podem receber resíduos industriais perigosos; Classe II, resíduos não perigosos; Classe II A não inertes e Classe II B, somente resíduos inertes.

Resíduos sólidos industriais não inertes normalmente têm sido encaminhados para disposição final em aterros controlados, que em sua maioria não operam de forma eficiente, além de estarem geralmente localizados próximos a núcleos populacionais e ecossistemas importantes.

$\mathrm{Na}$ disposição final do resíduo sólido, independente da técnica construtiva aplicada, existe o risco de contaminação das águas superficiais e subterrâneas. Esse risco está aliado às falhas que eventualmente possam ocorrer na construção e operação dos aterros e por infiltração e águas de chuva que aumentam consideravelmente a quantidade de percolado.

Assim, os dados geológicos e geotécnicos constituem-se em ferramentas fundamentais para a escolha do local mais apropriado para a disposição de resíduos sólidos, pois as informações obtidas através desses estudos contribuem, de forma decisiva, na minimização de impactos ambientais.

O termo "Metais Pesados", apesar de ser freqüentemente usado, não é muito bem definido, podendo-se empregar como sinônimos: "elementos traço", "microelementos", "metais traço", "micronutrientes", entre outros. Pode-se definir metal pesado como um grupo de elementos que ocorrem em sistemas 
naturais em pequenas concentrações e apresentam densidade igual ou acima de $5 \mathrm{~g} / \mathrm{cm}^{3}$ (ADRIANO, 1986).

\subsection{AS INDÚSTRIAS DE FERTILIZANTES FOSFATADOS}

A indústria do fosfato tem como principal objetivo fabricar fertilizantes fosfatados com teores elevados em $\mathrm{P}_{2} \mathrm{O}_{5}$ e de alta solubilidade em água para utilização na transformação de solos improdutíveis em férteis.

A produção de fertilizantes fosfatados de alta concentração em $\mathrm{P}_{2} \mathrm{O}_{5}$ é feita a partir de rochas fosfáticas e constitui-se de três fases: o beneficiamento físico do minério, o tratamento químico e a preparação das misturas fosfatadas comerciais.

Os depósitos de rochas fosfáticas são principalmente de origem ígnea e sedimentar, embora essas rochas possam resultar também do intemperismo, bem como de processos biológicos. Os depósitos de origem ígnea são responsáveis por $15 \%$ a $20 \%$ da produção mundial de rocha fosfática e os de origem sedimentar, por $80 \%$ a $85 \%$ (LIMA, 1989; FOSFÉRTIL, S.D).

Entretanto, cerca de $80 \%$ das reservas brasileiras são rochas ígneas, também chamadas magmáticas ou eruptivas, cujos teores de $\mathrm{P}_{2} \mathrm{O}_{5}$ variam de 4\% a 23\% (DNPM, 1976; LIMA, 1989). Essas rochas encontram-se, predominantemente, em Araxá (MG), Tapira (MG), Catalão (GO) e Jacupiranga $(\mathrm{SP})$.

O Brasil importa minério de fosfato natural de vários países, como Estados Unidos, Israel, Marrocos e Tunísia, tendo importado em 1992, por exemplo, cerca de 270 mil toneladas. O principal mineral componente das rochas fosfáticas nacionais de origem ígneas é a apatita.

Silva (1980) apresenta rochas fosfáticas da seguinte forma: "emprega-se o termo rochas fosfáticas na acepção de uma rocha natural, dotada de suficiente quantidade de minerais fosfatados (usualmente fosfatos de cálcio), de forma a permitir sua utilização de modo imediato, ou logo após ter sofrido processos de beneficiamento, na manufatura de produtos fertilizantes. Os principais minerais das rochas fosfáticas têm a estrutura apatita, cuja fórmula química é do tipo $\mathrm{Ca}_{10}\left(\mathrm{X}_{2}\right)\left(\mathrm{PO}_{4}\right)_{6}$, onde $\mathrm{X}$ representa os radicais hidroxila $(\mathrm{OH})$, 
cloreto $(\mathrm{Cl})$, fluoreto $(\mathrm{F})$ ou carbonato $\left(1 / 2 \mathrm{CO}_{3}\right)$, quer de maneira individual, quer de maneira coletiva. Dependendo do radical preponderante, as referidas apatitas passam a ser denominadas hidroapatita, cloroapatita, fluorapatita ou carboapatita, respectivamente.

As rochas fosfáticas de origem sedimentar estão localizadas principalmente em Pernambuco, e em Patos de Minas (MG), podendo-se destacar, nesse caso a fosforita. A fosforita é um fosfato tricálcio, amorfa, proveniente de organismos marinhos, ocorrendo geralmente associada a carbonatos de cálcio e de magnésio, óxidos de ferro e de alumínio e traços de urânio e de tório (GUERRA, 1979).

No Brasil, as principais jazidas de rochas fosfáticas estão situadas nas regiões nordeste e sudeste, sendo que a exploração mais significativa está na região sudeste. Esse fato torna importante a avaliação de todos os aspectos relacionados à utilização do fosfogesso uma vez que a proximidade dos grandes centros consumidores pode torná-lo competitivo o gesso natural, originário principalmente nas regiões norte e nordeste do País (ROSA, 1997).

\subsection{SUBPRODUTOS INDUSTRIAIS DO GESSO}

A gipsita é um mineral que se constitui na matéria prima para o gesso: sua fórmula química é $\mathrm{CaSO}_{4} \cdot 2 \mathrm{H}_{2} \mathrm{O}$. Sua extração mundial encontra-se em torno de 97 milhões de toneladas (SANTOS, 1998). Os Estados Unidos, com reservas de gipsita da ordem de 50 bilhões de toneladas, são os maiores produtores e consumidores mundiais (PEREIRA, 1973). Em segundo lugar está a China, com 10,68\%, e logo após o Irã, com 8,25\% (SUMÁRIO MINERAL, 1996).

No Brasil, apesar das reservas de gipsita chegarem a quase 654 milhões de toneladas, a produção ainda é pequena. As grandes reservas nacionais encontram-se no Norte e Nordeste do país, principalmente nos Estados do Pará com $60 \%$ e de Pernambuco com $30 \%$. Os restantes das reservas estão distribuídas pelos estados do Maranhão, Ceará, Rio Grande do Norte, Piauí e Tocantins (SUMÁRIO MINERAL, 1996). 
As melhores condições de aproveitamento das reservas de gipsita no Brasil são encontradas no Pólo Gesseiro do Araripe, localizado no Estado de Pernambuco, nordeste do Brasil. Com uma produção de aproximadamente 1,8 milhão de toneladas/ano, foi responsável por cerca de $96 \%$ da extração desse mineral em 1998. A gipsita extraída destina-se principalmente a calcinação (67\%) e à indústria cimenteira (33\%), sendo o uso para fins agrícolas inexpressivo $(0,1 \%)$. Do gesso natural obtido através da calcinação da gipsita, cerca de $96 \%$ destina-se diretamente ao emprego na construção civil, seja como gesso pra fundição (61\%) ou como gesso para revestimento (35\%). O restante da produção é distribuído entre a confecção de moldes para a indústria cerâmica (3\%) e o uso hospitalar (0,4\%) (SEBRAE, 1996; SUMÁRIO MINERAL, 1996).

Os nomes usados na literatura científica para se referir às famílias dos subprodutos do gesso são: gesso químico, gesso sintético, fosfogesso, fluorgesso, titaniogesso e disulfogesso. Do ponto mineralógico, todos esses materiais são sulfatos de cálcio, entretanto, produzido por diferentes processos industriais.

O gesso natural é obtido a partir da calcinação da gipsita e é encontrado na natureza sob a forma de sulfato de cálcio, (CaSO4. $\mathrm{nH} 2 \mathrm{O}$ ), em que $n=0,1 / 2 \mathrm{e}$ 2 indicam, respectivamente, as formas alotrópicas anidra, hemi-hidratada e dihidratada de sua estrutura cristalina (TRICHÊS \& MACCARINI, 1988).

Além do gesso natural, também podem ser encontrados no mercado brasileiro os gessos residuais ou químicos, como o fosfogesso, que é um subproduto obtido durante a produção do ácido fosfórico. Em 1995, a produção nacional de fosfogesso foi da ordem de 3,3 milhões de toneladas, entretanto apenas cerca de 844 mil toneladas foram comercializadas.

O gesso residual é obtido como subproduto durante a síntese ou neutralização de alguns ácidos e efluentes. Os subprodutos do gesso são encontrados em várias partes do mundo como um material de descarte, geralmente mantidos em depósitos a céu aberto. $\mathrm{O}$ fosfogesso contribui com a formação de depósitos que ocupam grandes áreas industriais, visto que vem sendo produzido em grande escala. A maior parte do fosfogesso não tem aplicação, tornando-se cada vez maiores os custos de implantação e de 
manutenção de seus depósitos e os problemas de espaço físico para sua armazenagem.

Destaca-se também o baixo consumo energético demandado na produção do gesso e a possibilidade de utilização de resíduos provenientes da indústria química (gesso residual), uma vez que a preocupação com o meio ambiente vem assumindo peso cada vez maior na hora da escolha dos materiais empregados nas indústrias de uma maneira geral.

\subsection{FOSFOGESSO}

O fosfogesso é um subproduto sólido gerado pelas indústrias de fertilizantes fosfatados durante a produção do ácido fosfórico $\left(\mathrm{H}_{3} \mathrm{PO}_{4}\right)(\mathrm{CHANG}$, \& MANTELL, 1990). A sua denominação, fosfogesso, indica sua origem industrial (fosfo) e seu componente principal (gesso). Esse subproduto é sulfato de cálcio $\left(\mathrm{CaSO}_{4}\right)$ e, portanto, apresenta a mesma composição que o gesso natural.

Devido à abundância e sua larga distribuição geográfica, o gesso tem um valor mineral baixo e, em muitos casos, seu valor no solo antes da exploração é considerado praticamente zero. Em face da competição econômica com o gesso, o uso prático do fosfogesso requer pesquisas inovadoras e contínuas.

A Figura 2.1 ilustra as etapas do processo de obtenção do fosfogesso durante a fabricação do ácido fosfórico, (MANGIN, 1978).

De acordo com os processos para a produção do ácido fosfórico, podem ser obtidos diferentes tipos de fosfogesso. Esses processos podem ser: por via úmida, também conhecido como processo úmido, e o processo da fornalha elétrica (alto-forno ou via térmica) (TAHA \& SEALS, 1991).

O processo por via úmida (ou simplesmente: processo úmido) é o mais utilizado e usa o ácido sulfúrico como umas das matérias-primas para reagir com uma pasta fluida composta de rochas fosfáticas dissolvidas em ácido sulfúrico. Durante o processo úmido, diferentes composições de fosfogesso são obtidas: di-hidratado $(\mathrm{DH})$, hemi-hidratado $(\mathrm{HH})$, hemi-di-hidratado $(\mathrm{HDH})$, e anidro (PARREIRA, 2002). 


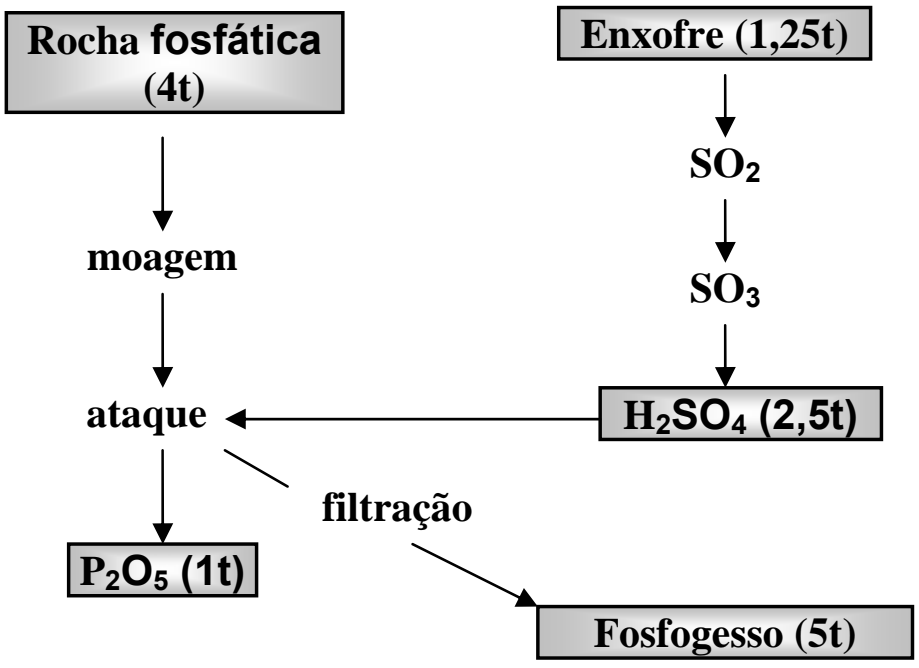

FIGURA 2.1 - Diagrama representando as etapas do processo de obtenção do fosfogesso, (MANGIN, 1978)

A temperatura e a concentração do ácido fosfórico são os fatores responsáveis pelas diferentes formas alotrópicas do fosfogesso. As formas dihidratado, hemi-hidratado e anidro dependem principalmente da temperatura de reação entre a rocha fosfática e das concentrações de ácido fosfórico impregnadas no resíduo. Essa concentração é determinada pela quantidade de água de lavagem usada para remover o $\mathrm{P}_{2} \mathrm{O}_{5}$ do sulfato de cálcio durante a filtragem (TAHA \& SEALS, 1991).

Segundo Mangin (1978a), Barbosa (1980), Fergunson (1988), e Haridasan et al. (2000), o fosfogesso, obtido através do processo úmido, é descrito pela equação abaixo:

$\left[\mathrm{Ca}_{3}\left(\mathrm{PO}_{4}\right)_{2}\right]_{3} \mathrm{CaF}_{2}+10 \mathrm{H}_{2} \mathrm{SO}_{4}+10 n \mathrm{H}_{2} \mathrm{O} \rightarrow 6 \mathrm{H}_{3} \mathrm{PO}_{4}+10\left(\mathrm{CaSO}_{4}+n \mathrm{H}_{2} \mathrm{O}\right)+2 \mathrm{HF}$ eq.(1)

em que:

$\left[\mathrm{Ca}\left(\mathrm{PO}_{4)}\right]_{3} \mathrm{CaF}_{2}^{-}\right.$: Fluoropatita

$\mathrm{H}_{2} \mathrm{SO}_{4}$ : ácido sulfúrico

$\mathrm{H}_{2} \mathrm{O}$ : água

$\mathrm{CaSO}_{4} \cdot \mathrm{nH}_{2} \mathrm{O}$ : fosfogesso

$\mathrm{H}_{3} \mathrm{PO}_{4}$; ácido fosfórico

HF: ácido sulfúrico

O $n$ na equação pode ter três valores diferentes: para $n=20$ fosfogesso obtido é da forma di-hidratado $\left(\mathrm{CaSO}_{4} \cdot 2 \mathrm{H}_{2} \mathrm{O}\right)$; para $0 n=1 / 2$, o fosfogesso 
obtido é da forma hemi-hidratado $\left(\mathrm{CaSO}_{4} \cdot 1 / 2 \mathrm{H}_{2} \mathrm{O}\right)$; e para o $n=0$ o fosfogesso é anidro $\left(\mathrm{CaSO}_{4}\right)$.

Os tipos mais comuns são formados de acordo com o processo úmido conforme citado abaixo:

\subsubsection{Processo di-hidratado (DH).}

Alguns pesquisadores como Mangin (1978), Kouloheris (1980), Chang \& Mantell (1990) e Taha \& Seals (1991) definiram este processo como o mais utilizado mundialmente, para a produção do ácido fosfórico, principalmente nos EUA. Esse processo desenvolve-se em temperaturas entre $71^{\circ} \mathrm{C}$ a $85^{\circ} \mathrm{C}\left(160^{\circ} \mathrm{F}\right.$ a $\left.185^{\circ} \mathrm{F}\right)$, resultando o fosfogesso di-hidratado $(\mathrm{DH})$. Esse intervalo de temperatura empregado é considerado baixo em comparação às temperaturas usadas nos demais processos. Pelo processo di-hidratado são obtidas concentrações de anidrido fosfórico que variam de $28 \%$ a $30 \%$. Neste processo quando produzido 1 tonelada de ácido fosfórico é gerado cerca de 5 toneladas de fosfogesso di-hidratado $(\mathrm{DH}),\left(\mathrm{CaSO}_{4} \cdot 2 \mathrm{H}_{2} \mathrm{O}\right)$.

Dentre as vantagens que fazem desse processo o mais utilizado em todo o mundo se comparado com os processos que produzem o fosfogesso hemi-hidratado ou anidro, pode citar: baixo investimento de capital para implantação do sistema de produção, custo de produção relativamente baixo e grande flexibilidade para o uso de rochas de várias origens. Além dessas vantagens, é possível efetuar-se a extração do urânio presente na sua composição.

As desvantagens de obtenção de fosfogesso di-hidratado estão ligadas ao menor rendimento de produção do ácido fosfórico, e às grandes quantidades de impurezas presentes no fosfogesso obtido, tais como resíduos de ácidos fosfórico e sulfúrico e de metais pesados que, podem poluir o meio ambiente. Mangin (1978) argumentou que esse tipo de fosfogesso tem recebido maior incentivo para reciclagem por ser mais poluente e gerar maior acúmulo de material nos depósitos, em comparação aos outros tipos. 
Chang \& Mantell (1990) apresentaram resultados de análises químicas desse tipo de fosfogesso obtido de uma rocha de boa qualidade sob boas condições de operação mostrados na Tabela 2.1.

TABELA 2.1 - Composição do fosfogesso do tipo di-hidratado (DH) fonte Chang e Mantell, (1990)

\begin{tabular}{cc}
\hline Composição & $\mathbf{( \% )}$ \\
\hline $\mathrm{CaO}$ & 32,50 \\
$\mathrm{SO}_{3}$ & 44,00 \\
$\mathrm{P}_{2} \mathrm{O}_{5}$ & 0,65 \\
$\mathrm{~F}$ & 1,20 \\
$\mathrm{SiO}_{2}$ & 0,50 \\
$\mathrm{Fe}_{2} \mathrm{O}_{3}$ & 0,10 \\
$\mathrm{Al}_{2} \mathrm{O}_{3}$ & 0,10 \\
$\mathrm{H}_{2} \mathrm{O}$ cristalizada & 19,00 \\
\hline
\end{tabular}

\subsubsection{Processo hemi-hidratado $(\mathrm{HH})$}

Este tipo de processo é empregado na África, Europa e principalmente no Japão. O fosfogesso hemi-hidratado $(\mathrm{HH})$ é obtido em intervalo de temperaturas variando de $93^{\circ} \mathrm{C}$ a $132^{\circ} \mathrm{C}$ e produz ácido fosfórico hemihidratado a concentrações de $38 \%$ a $42 \%$ de $\mathrm{P}_{2} \mathrm{O}_{5}$. A produção de 1 tonelada de ácido fosfórico gera aproximadamente 4,3 toneladas de fosfogesso hemihidratado.

As vantagens do processo hemi-hidratado com relação ao processo dihidratado, são as concentrações mais altas de $\mathrm{P}_{2} \mathrm{O}_{5}$, a dissolução mais rápida da rocha fosfática e a maior velocidade de filtração do ácido fosfórico. A maior concentração de $\mathrm{P}_{2} \mathrm{O}_{5}$ gera partículas mais finas de fosfogesso e com menores quantidades de impurezas, (KOULOHERIS, 1980).

No Japão, a maioria das fábricas de fertilizantes fosfatados utiliza um método modificado do processo hemi-hidratado que transforma diretamente o fosfogesso em matéria-prima para a produção de cimento Portland, sem que o mesmo passe por onerosos tratamentos de purificação. Esse método é conhecido como processo "hemi nissan", resultando no tipo de fosfogesso de mesmo nome, utilizado como substituto do gesso natural. A implantação desse processo no Japão é estimulada pela carência de jazidas minerais de gipsita 
em seu território. Goers (1980) explicou que esse método, além de ser o primeiro a produzir fosfogesso de qualidade suficiente para seu emprego imediato na indústria do cimento, pode se adaptar a outras aplicações desse resíduo na construção civil, como na produção de argamassas e blocos de alvenaria.

Kouloheris (1980) \& Chang \& Mantell (1990) apresentaram as análises desse tipo de fosfogesso de uma rocha de boa qualidade sob boas condições de operação mostrados na Tabela 2.2.

TABELA 2.2 - Composição do fosfogesso do tipo hemi-hidratado (HH), fonte Chang e Mantell, (1990) \& Kouloheris, (1980)

\begin{tabular}{cc}
\hline Composição & $\mathbf{( \% )}$ \\
\hline $\mathrm{CaO}$ & 36,90 \\
$\mathrm{SO}_{3}$ & 50,30 \\
$\mathrm{P}_{2} \mathrm{O}_{5}$ & 1,55 \\
$\mathrm{~F}$ & 0,8 \\
$\mathrm{SiO}_{2}$ & 0,70 \\
$\mathrm{Fe}_{2} \mathrm{O}_{3}$ & 0,10 \\
$\mathrm{Al}_{2} \mathrm{O}_{3}$ & 0,30 \\
$\mathrm{H}_{2} \mathrm{O}$ cristalizada & $22,00^{*}$
\end{tabular}

\section{Valor aproximado}

\subsubsection{Processo hemi-di-hidratado (HDH)}

O processo hemi-di-hidratado é utilizado na Europa e Japão. O processo desenvolve-se a temperaturas variando de $90^{\circ} \mathrm{C}$ a $100^{\circ} \mathrm{C}\left(194^{\circ} \mathrm{F}\right.$ a $\left.212^{\circ} \mathrm{F}\right)$. As concentrações de ácido fosfórico obtidas variam de $40 \%$ a $52 \%$.

O processo hemi-di-hidratado $(\mathrm{HDH})$ possibilita alcançar um resíduo mais limpo, como o obtido pelo processo hemi-hidratado. $\mathrm{O}$ processo $\mathrm{HDH}$ envolve a precipitação do sulfato de cálcio na forma hemi-hidratada seguida da sua recristalização para a forma di-hidratada (LEGAL \& MYRICK, 1968 apud TAHA \& SEALS, 1991). ${ }^{1}$

A razão da produção entre o fosfogesso e o ácido fosfórico é igual a do processo hemi-hidratado, ou seja, para cada tonelada de ácido fosfórico são

${ }^{1}$ LEGAL, C. C. \& MYRICK, O. D., Jr. (1968). History and status of phosphoric acid. Phosphoric Acid, v.1, part 1, New York 
obtidas 4,3 toneladas de fosfogesso. A economia de energia também é uma característica desse processo, entretanto, os custos de manutenção dos equipamentos são maiores do que no processo $\mathrm{DH}$.

Chang \& Mantell, (1990) apresentaram a composição desse tipo de fosfogesso de uma rocha de boa qualidade sob boas condições de operação mostrados na Tabela 2.3 .

TABELA 2.3 - Composição do fosfogesso do tipo hemi-di-hidratado (HH)

\begin{tabular}{cc}
\hline Composição & $(\%)$ \\
\hline $\mathrm{CaO}$ & 32,20 \\
$\mathrm{SO}_{3}$ & 46,50 \\
$\mathrm{P}_{2} \mathrm{O}_{5}$ & 0,25 \\
$\mathrm{~F}$ & 0,50 \\
$\mathrm{SiO}_{2}$ & 0,40 \\
$\mathrm{Fe}_{2} \mathrm{O}_{3}$ & 0,050 \\
$\mathrm{Al}_{2} \mathrm{O}_{3}$ & 0,30 \\
$\mathrm{H}_{2} \mathrm{O}$ cristalizada & $20,00^{*}$
\end{tabular}

Valor aproximado.

\subsubsection{Processo anidro}

Esse processo produz o fosfogesso em condição anidra é desenvolvido no intervalo de temperaturas de $120^{\circ} \mathrm{C}$ a $130^{\circ} \mathrm{C}$. A produção de 1 tonelada de ácido fosfórico gera cerca de 3,5 toneladas de fosfogesso anidro. Apesar de produzir menor quantidade de fosfogesso, poucas fábricas no mundo adotam o processo anidro, devido aos elevados custos de produção provocados pela corrosão acelerada de máquinas e equipamentos industriais e pelo alto consumo de energia. Nesse processo, a concentração $\mathrm{P}_{2} \mathrm{O}_{5}$ no ácido fosfórico produzido atinge aproximadamente $50 \%$.

Os custos de produção relativamente mais altos possibilitam a obtenção de um fosfogesso produzido em menor quantidade e com menos impurezas. Mesmo assim, são mais vantajosos, sob o ponto de vista econômico, os processos di-hidratado e hemi-hidratado (PARREIRA, 2002). 
No processo por via térmica é produzido o termofosfato, através de transformações físicas e reações químicas entre o concentrado fosfático e escórias magnesianas em altas temperaturas (CARMO, 1994).

Taha \& Seals (1991) citam que o processo por via térmica é descrito em três etapas. A primeira é feita através da redução química de rochas fosfáticas em fósforos elementares $\left(\mathrm{P}_{4}\right)$. Na segunda etapa, ocorre a oxidação do $\mathrm{P}_{4}$ por combustão realizada em fornalhas elétricas, resultando em vapores de óxido de fósforo $\left(\mathrm{P}_{4} \mathrm{O}_{10}\right)$. Na terceira etapa, ocorre o processo de hidratação do $\mathrm{P}_{4} \mathrm{O}_{10}$, que reage com a água produzindo o ácido fosfórico $\left(\mathrm{H}_{3} \mathrm{PO}_{4}\right)$.

O ácido fosfórico assim produzido geralmente alcança concentrações de $54 \%$, podendo ser maior reduzindo-se a quantidade de água usada na etapa de hidratação do $\mathrm{P}_{4} \mathrm{O}_{10}$. A concentração é medida em termos de $\mathrm{P}_{2} \mathrm{O}_{5}$ (anidrido fosfórico), que é a forma anidra do ácido fosfórico. A utilização do processo de alto-forno está restrita ao uso de rochas fosfáticas que possuem elevada concentração de apatita, de forma a fornecer, após seu processamento, quantidade suficiente de fósforos elementares para compensar os custos de consumo energético durante essa operação. A ocorrência de rochas fosfáticas de tal qualidade é pequena, a ponto de dificultar a implantação desse processo, optando-se, na maioria dos casos, pelo processo por via úmida.

\subsubsection{Considerações complementares}

Goers apud Gregory et al. $(1984)^{2}$ considerou que o tipo e a granulometria do fosfogesso obtido afetam a quantidade de ácido fosfórico produzido pelo processo úmido, podendo, dessa forma, influenciar as propriedades mecânicas do fosfogesso, principalmente quando usado em misturas estabilizadas.

Visto que o fosfogesso bruto ou em seu estado natural é um composto de sulfato de cálcio acrescido de uma combinação de impurezas, cujas quantidades variam de acordo com a rocha fosfática e com o processo de fabricação do ácido fosfórico, a sua adequação ao uso industrial exige que o

${ }^{2}$ GOERS, W. E. (1980). Nissan Hemi Phosphogypsum. In: PROCEEDINGS INTERNATIONAL SYMPOSIUM ON PHOSPHOGYPSUM, Lake Buena Vista, Florida, 5-7 November, 1980. v. 1, p. $36-52$. 
mesmo receba um tratamento de purificação, que consiste na retirada da maior parte de suas impurezas - as que realmente afetam seu desempenho e o meio ambiente.

\subsection{DISPOSIÇÃO DO FOSFOGESSO}

A maneira de disposição do fosfogesso mais indicada depende das disponibilidades e dos custos das áreas apropriadas, da localização da fábrica de ácido fosfórico e da legislação ambiental local.

O empilhamento em áreas próximas às fábricas é a forma mais comum de depósito do fosfogesso, para a qual existem duas alternativas: disposição "a úmido" ou "a seco".

Na disposição "a úmido", o gesso é depositado juntamente com a água ácida residual da unidade de ácido fosfórico, na forma de uma suspensão, com teores de sólidos variando de $5 \%$ a $20 \%$. Essa suspensão é bombeada para lagoas de sedimentação, onde o gesso, depois de decantado, é acumulado em pilhas, por meio de "draglines". As lagoas de sedimentação são limitadas por diques construídos com o próprio fosfogesso. A água ácida separada é drenada, através de canais que circundam as pilhas, para lagoas de processo, que atuam como lagoas-pulmão com a finalidade de coletar as águas das chuvas, para subseqüente evaporação pelo calor solar. Essas lagoas funcionam também como locais de resfriamento para posterior recirculação da água ácida, para reutilização na planta de produção de ácido fosfórico.

Na disposição "a seco", o fosfogesso é depositado da unidade de ácido fosfórico, sendo transportado por correias ou caminhões para área de disposição final, onde é acumulado em pilhas.

\subsection{CARACTERÍSTICAS FÍSICAS DO FOSFOGESSO}

Os resultados da análise física do fosfogesso encontrados em bibliografia apresentam diferenças quando comparados entre si em razão das diferentes origens das amostras analisadas (SILVESTRE, 2002).

Ghafoori \& Chang (1993) argumentaram que a granulometria do fosfogesso varia de acordo com o processo de fabricação do ácido fosfórico, da 
origem geológica e mineralógica da rocha fosfática e do tempo de lixiviação do fosfogesso em depósitos. Os autores citaram o grau de moagem da rocha fosfática durante a etapa inicial de produção do ácido fosfórico como um dos fatores que determinam a composição granulométrica do fosfogesso formado.

As partículas mais grossas, por exemplo, são constituídas de areias siltosas e de fragmentos não-reativos de rocha fosfática que não foram processados na fábrica de fertilizantes fosfatados.

A Tabela 2.4 apresenta os resultados dos estudos realizados por Taha \& Seals (1991) referente à análise física dos fosfogessos produzidos nos estados da Louisiana, Texas e Florida.

\begin{tabular}{|c|c|c|c|}
\hline \multirow{2}{*}{ Propriedades } & \multicolumn{3}{|c|}{ Valores } \\
\hline & Louisiana & Texas & Florida \\
\hline Umidade (\%) & $8-12$ & 20 & $3-18$ \\
\hline Massa específica dos sólidos (g.cm $\left.{ }^{-3}\right)$ & $2,32-2,35$ & 2,30 & $2,31-2,53$ \\
\hline Partículas passantes na peneira \#200 (\%) & $74-75$ & 75 & $30-82$ \\
\hline
\end{tabular}

Além dos resultados apresentados na Tabela 2.4, Taha, Seals, Tittlebaum e Saylak, (1992), apresentaram as análises físicas do fosfogesso, coletado das pilhas da Companhia Química Agrícola Uncle sam Plant, no estado de Louisiana, conforme mostra a Tabela 2.5.

TABELA 2.5 - Resultados das análises físicas do fosfogesso. Fonte Taha, Seals, Tittlebaum e Saylak

\begin{tabular}{cc}
\hline Propriedades & Fosfogesso \\
\hline Umidade livre (\%) & $8-18$ \\
Umidade estrutural (\%) & $25-30$ \\
Densidade específica & 2,35 \\
\hline
\end{tabular}

A umidade livre desse material foi obtida com amostras secas em temperaturas abaixo de $55^{\circ} \mathrm{C}\left(131^{\circ} \mathrm{F}\right)$. Esses autores chegaram à conclusão, que o fosfogesso é considerado como material não plástico, consistindo de partículas finas, comparáveis à areia fina e silte. Baseada na classificação 
USCS, esse material pode ser classificado como ML. A Figura 2.2 mostra a curva granulométrica desse fosfogesso.

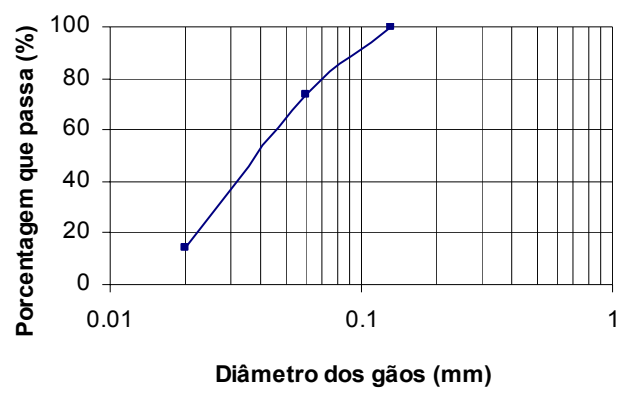

FIGURA 2.2 - Curva de distribuição granulométrica do fosfogesso do estado de Louisiana

No Brasil, Ortiz (1997) realizou ensaios de laboratório para caracterizar fisicamente amostras de fosfogesso anidro obtidas em depósitos da indústria de fertilizantes FOSFÉRTIL, localizada no município de Uberaba (MG). O autor verificou que esse tipo de material, quando encontrado em seu estado natural, possui granulometria variada, com grande percentual de partículas finas, cujos diâmetros enquadram-se na faixa entre 0,02 e $0,5 \mathrm{~mm}$, como solo argiloso. $\mathrm{O}$ fosfogesso anidro apresentou também índice de plasticidade nulo.

Takeda (1998) realizou as análises granulométricas em amostras de dois fosfogessos de diferentes idades produzidos pela indústria de fertilizantes fosfatados FOSFÉRTIL. Essas análises, baseadas pela norma brasileira DERSP M 6-61, mostraram que o fosfogesso comporta-se granulometricamente como um silte, conforme ilustrado na Figura 2.3.

Gregory et al. (1994), Nanni \& Chang (1989) e Ghafoori \& Chang (1993) encontraram, respectivamente, os seguintes valores de massa específica dos sólidos de fosfogesso di-hidratado de diferentes fontes, originados do EUA com amostras de diferentes fontes: $2,30 \mathrm{~g} / \mathrm{cm}^{3}, 2,42 \mathrm{~g} / \mathrm{cm}^{3}$ e $2,39 \mathrm{~g} / \mathrm{cm}^{3}$. O valor encontrado por Maccarini (1991) da massa específica dos sólidos do fosfogesso di-hidratado produzido em Santa Catarina, Brasil, foi de $2,40 \mathrm{~g} / \mathrm{cm}^{3}$. 


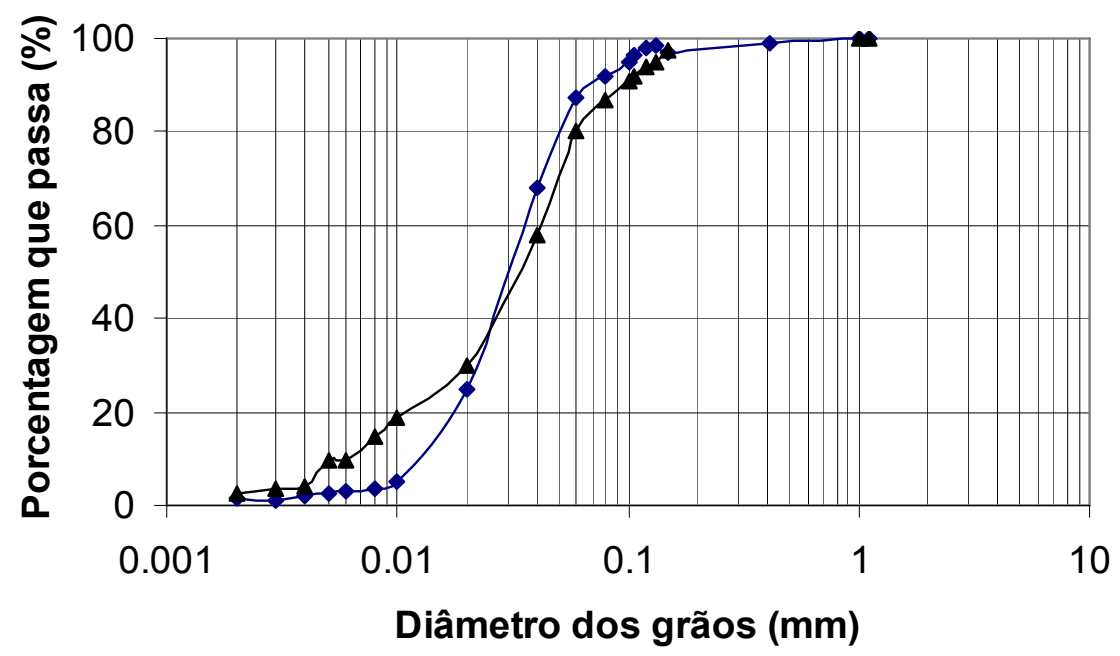

FIGURA 2.3 - Curvas granulométricas de dois fosfogesso (TAKEDA, 1998)

\subsection{CARACTERÍSTICAS QUÍMICAS}

Silvestre (2002) cita que os mesmos fatores responsáveis pelas características físicas do fosfogesso também interferem nas características químicas. Os fatores supra citados interferem também nas características qualitativas e quantitativas de suas impurezas (dentre elas, metais pesados e elementos radioativos).

No processo úmido, particularmente, a definição da composição química do fosfogesso está relacionada aos processos de reação química entre suas matérias-primas e do grau de filtragem usado na separação entre o ácido fosfórico e o fosfogesso.

No Brasil, Trichês \& Maccarini (1988), Freitas (1992) e Kobayashi (2000), apresentaram as características químicas do fosfogesso coletado da Indústria Carboquímica Catarinense - ICC, localizado no Estado de Santa Catarina, catalão Ultrafértil e na Indústria de fertilizantes FOSFÉRTIL, localizada em Uberaba (MG), respectivamente, conforme apresentado nas Tabelas 2.6, 2.7 e 2.8. 
TABELA 2.6 - Composição do fosfogesso estudado por Trichês \& Maccarini, 1988, produzido em Santa Catarina

\begin{tabular}{cc}
\hline Compostos & Teor (\%) \\
\hline $\mathrm{SIO}_{2}$ e mat. insolúvel & $4,0 \%$ \\
$\mathrm{Fe}_{2} \mathrm{O}_{3}+\mathrm{Al}_{2} \mathrm{O}_{3}$ & $3,5 \%$ \\
$\mathrm{CaO}$ & $37,0 \%$ \\
$\mathrm{SO}_{4}$ & $51,5 \%$ \\
$\mathrm{MgO}$ & $0,42 \%$ \\
$\mathrm{P}_{2} \mathrm{O}_{5}$ & $1,22 \%$ \\
Densidade real & 2,4 \\
\hline
\end{tabular}

TABELA 2.7 - Análise do fosfogesso realizada por Freitas, (1992)

\begin{tabular}{ccccc}
\hline \multirow{2}{*}{ Componente } & \multicolumn{4}{c}{ Teor (\%) } \\
\cline { 2 - 5 } & $\begin{array}{c}\text { Tapira } \\
\text { (Fosfértil) }\end{array}$ & Araxá (ICC) & $\begin{array}{c}\text { Catalão } \\
\text { (Ultrafértil) }\end{array}$ & Flórida \\
\hline $\mathrm{CaO}$ & 31,96 & 30,28 & 31,71 & 32,50 \\
$\mathrm{SO}_{3}$ & 44,00 & 40,50 & 44,89 & 44,00 \\
$\mathrm{P}_{2} \mathrm{O}_{5}$ & 0,78 & 1,26 & 0,56 & 0,65 \\
$\mathrm{Fe}_{2} \mathrm{O}_{3}$ & 0,17 & 0,59 & 0,35 & 0,10 \\
$\mathrm{Al}_{2} \mathrm{O}_{3}$ & 0,04 & 0,17 & 0,12 & 0,10 \\
$\mathrm{SiO}_{2}$ & 1,58 & 0,34 & 0,92 & 0,50 \\
$\mathrm{TiO}_{2}$ & 0,13 & 0,08 & 0,38 & - \\
$\mathrm{BaO}$ & - & - & 0,10 & - \\
$\mathrm{K}_{2} \mathrm{O}$ & 0,03 & - & - & - \\
$\mathrm{MgO}$ & - & 0,09 & 0,01 & 0,10 \\
$\mathrm{Na} O$ & 0,05 & - & 0,06 & - \\
$\mathrm{F}$ & 0,25 & 0,58 & 0,57 & 1,20 \\
\hline
\end{tabular}

TABELA 2.8 - Composição do fosfogesso estudado por Kobayashi, (IPT, 2000 )

\begin{tabular}{cc}
\hline Composição & Teor(\%) \\
\hline Água livre ou umidade higroscópica & 0,11 \\
Água combinada & 18,80 \\
Cal $-\mathrm{CaO}^{(1)}$ & 31,50 \\
Anidrido sulfúrico $-\mathrm{SO}_{3}{ }^{(1)}$ & 44,30 \\
Sesquióxidos $-\mathrm{R}_{2} \mathrm{O}_{3}{ }^{(1,2)}$ & 1,07 \\
Anidrido fosfórico $-\mathrm{P}_{2} \mathrm{O}_{5}{ }^{(1)}$ & 0,31 \\
Insolúveis em ácido clorídrico $-\mathrm{RI}^{+} \mathrm{SiO}_{2}{ }^{(1)}$ & 2,48 \\
Anidrido carbônico $-\mathrm{CO}_{2}{ }^{(1)}$ & n.d. \\
Magésio $-\mathrm{Mg}^{(1)}$ & 0,09 \\
\hline (1) Ensaios que realizados em amostras isentas de água livre ou umidade \\
higroscópica.
\end{tabular}

(2) Possivelmente o $\mathrm{R}_{2} \mathrm{O}_{3}$ é constituído preponderantemente por $\mathrm{Fe}_{2} \mathrm{O}_{3}, \mathrm{Al}_{2} \mathrm{O}_{3}$ e $\mathrm{P}_{2} \mathrm{O}_{5}$.

N.D. Não determinado.

A Tabela 2.9 mostra alguns resultados das análises químicas de fosfogesso di-hidratado produzido na Turquia por (Erdem \& Ölmez, 1989), nos 
estados norte-americanos da Florida, Louisiana e Texas (Taha \& Seals, 1991) e na Jordânia (Mohammad et al., 1999).

TABELA 2.9 - Composição química típica dos fosfogesso di-hidratado encontrado na Turquia (ERDEM \& ÖLMEZ, 1989), nos estados norte-americanos de Louisiana, Texas e Florida (TAHA \& SEALS, 1991) e na Jordânia (MOHAMMAD et al., 1999)

\begin{tabular}{cccccc}
\hline \multirow{2}{*}{ Composto } & \multicolumn{5}{c}{ Teor (\%) } \\
\cline { 2 - 6 } & Turquia & Louisiana & EUA Texas & Florida & Jordânia \\
\hline $\mathrm{CaO}$ & 30,7 & $29-31$ & 32,5 & $25-31$ & 34,09 \\
$\mathrm{SO}_{3}$ & 42,66 & $50-53$ & 53,1 & $55-58$ & 47,19 \\
$\mathrm{SiO}_{2}$ & n.d. & $5-10$ & 2,5 & $3-18$ & 1,24 \\
$\mathrm{~F}$ & 0,79 & $0,3-1,0$ & 1,2 & $0,2-0,8$ & n.d. \\
$\mathrm{P}_{2} \mathrm{O}_{5}$ & 1,02 & $0,7-1,3$ & 0,65 & $0,5-4,0$ & 0,90 \\
$\mathrm{Fe}_{2} \mathrm{O}_{3}$ & 0,5 & $0,1-0,2$ & 0,1 & $0-0,1$ & 0,64 \\
$\mathrm{Al}_{2} \mathrm{O}_{3}$ & 0,5 & $0,1-0,3$ & 0,1 & $0,1-0,3$ & 0,06 \\
$\mathrm{pH}$ & n.d. & $2,8-5,0$ & $2,6-5,0$ & $2,5-6,0$ & n.d. \\
\hline n.d. - não determinado. & & & &
\end{tabular}

A Tabela 2.10 apresenta a composição química do fosfogesso dihidratado e anidro obtido através de calcinação a $800^{\circ} \mathrm{C}$ durante 4 horas estudadas por Singh et al. (1990).

TABELA 2.10 - Composição química do fosfogesso di-hidratado e anidro. Fonte Singh, 1990.

\begin{tabular}{ccc}
\hline Constituintes & Fosfogesso (\%) & Anidro (\%) \\
\hline $\mathrm{P}_{2} \mathrm{O}_{5}$ & 0,55 & 0,69 \\
$\mathrm{~F}$ & 1,80 & 0,97 \\
Matéria orgânica & 0,11 & - \\
$\mathrm{SiO}_{2}+\mathrm{insolúvel} \mathrm{em} \mathrm{HCl}_{\mathrm{R}_{2} \mathrm{O}_{3}\left(\mathrm{Al}_{2} \mathrm{O}_{3}+\mathrm{Fe}_{2} \mathrm{O}_{3}\right)}$ & 0,98 & 1,26 \\
$\mathrm{CaO}$ & 0,48 & 0,50 \\
$\mathrm{MgO}$ & 32,40 & 38,60 \\
$\mathrm{SO}$ & 0,70 & 0,06 \\
$\mathrm{~S}$ & 43,00 & 54,20 \\
$\mathrm{Mn}_{2} \mathrm{O}_{3}$ & - & - \\
Perda por ignição & - & - \\
\end{tabular}

Comparando os valores apresentados nas tabelas acima, pode-se observar que as composições do fosfogesso variam de acordo com o lugar de onde foi gerado. Possivelmente esta variação deve-se a rocha fosfática usada no processo de fabricação do ácido fosfórico, entre outros fatores citados anteriormente na revisão. 
Conhecido como uma espécie de "gesso sujo", sua composição concentra vários tipos de impurezas fáceis de serem detectadas por análises químicas simples. A concentração de gesso ou de sulfato de cálcio no fosfogesso situa-se na faixa de $80 \%$ a $90 \%$, e o percentual restante é constituído pelas impurezas.

As rochas nacionais, usadas nas fábricas brasileiras de ácido fosfórico, geralmente apresentam teores de metais pesados, fluoretos, radioatividade e outras impurezas menores do que as rochas de outros países. As análises de fosfogesso indicaram teores abaixo dos limites permitidos para o uso agrícola (FREITAS, 1992).

O fosfogesso não pode ser usado em muitas aplicações como um substituto do gesso natural, sem antes passar por um processo de purificação.

No processo de fabricação do ácido fosfórico são transferidas para o fosfogesso impurezas insolúveis contidas na rocha fosfática, tais como metais pesados, fluoretos e nuclídeos radioativos. Os teores das impurezas encontrados no fosfogesso dependem da origem da rocha fosfática, do processo de produção usado e da eficiência da operação da fábrica. Essas impurezas ocorrem independentemente da forma do fosfogesso obtido, hemi ou di-hidratado.

As impurezas encontradas no fosfogesso podem ser formadas por vários elementos químicos, tais como: arsênio $(\mathrm{AS})$, bário $(\mathrm{Ba})$, cádmio $(\mathrm{Cd})$, cromo $(\mathrm{Cr})$, chumbo $(\mathrm{Pb})$, mercúrio $(\mathrm{Hg})$, selênio $(\mathrm{Se})$ e prata $(\mathrm{Ag})$, também conhecidos como metais pesados porque possuem massa atômica elevada.

A Tabela 2.11 apresenta as concentrações típicas dos metais pesados encontrados na composição do fosfogesso bruto do estado de Louisiana. Quando esses elementos são encontrados em níveis de concentrações, acima dos recomendados pela norma NBR 10.004 - (CLASSIFICAÇÃO DE RESÍDUOS SÓLIDOS), tornam-se poluentes, oferecendo riscos como contaminação de solos e de mananciais de água que estejam nas proximidades de depósitos de fosfogesso. Além de metais pesados também podem estar presentes os compostos químicos tais como: sílica $\left(\mathrm{SiO}_{2}\right)$, os óxidos de ferro $\left(\mathrm{Fe}_{2} \mathrm{O}_{3}\right)$, de alumínio $\left(\mathrm{Al}_{2} \mathrm{O}_{3}\right)$ e de magnésio $(\mathrm{MgO})$. 
TABELA 2.11 - Concentrações típicas de traços de elementos no fosfogesso do estado de Luisiana. Fonte: TAHA et al. (1995).

\begin{tabular}{cc}
\hline Elementos & Concentração $(\mathbf{m g} / \mathbf{L})$ \\
\hline $\mathrm{As}$ & $1-5$ \\
$\mathrm{Ba}$ & 50 \\
$\mathrm{Cd}$ & $0,3-0,4$ \\
$\mathrm{Cr}$ & $2-5$ \\
$\mathrm{~Pb}$ & $2-10$ \\
$\mathrm{Hg}$ & $0,02-0,05$ \\
$\mathrm{Se}$ & 1,0 \\
$\mathrm{Ag}$ & $0,1-0,2$ \\
$\mathrm{SO}_{4}(\%)$ & $\mathrm{NA}$ \\
\hline
\end{tabular}

NA = não avaliado.

Existem também impurezas que não pertencem à sua composição química, conhecida como impurezas livres, constituídas por areia, matéria orgânica, pequenos fragmentos não-reativos de rocha fosfática e ácido fosfórico $\left(\mathrm{H}_{3} \mathrm{PO}_{4}\right)$, também na forma anidra $\left(\mathrm{P}_{2} \mathrm{O}_{5}\right)$ analisados sob três condições: solúvel em água, solúvel em citrato e insolúvel em citrato. Os ácidos sulfúricos $\left(\mathrm{H}_{2} \mathrm{SO}_{3}\right)$ e fluorídricos $(\mathrm{HF})$ também fazem parte das impurezas livres do fosfogesso.

Ainda com relação à composição química, na Tabela 2.12 são apresentadas as concentrações de traços de elementos presentes no fosfogesso do "Freeport-McMoran, TAHA et al., (1992).

TABELA 2.12 - Concentrações de traços de elementos presentes no fosfogesso do "Freeport-McMoran, Inc" (TAHA et al., 1992).

\begin{tabular}{cc}
\hline Elemento & Concentração $(\mathrm{ppm})$ \\
\hline $\mathrm{As}$ & $1-5$ \\
$\mathrm{Ba}$ & 50 \\
$\mathrm{Cd}$ & $0,3-0,4$ \\
$\mathrm{Cr}$ & $2-5$ \\
$\mathrm{~Pb}$ & $2-10$ \\
$\mathrm{Hg}$ & $0,02-0,05$ \\
$\mathrm{Se}$ & 1 \\
$\mathrm{Ag}$ & $0,1-0,2$ \\
$\mathrm{U}_{3} \mathrm{O}_{8}$ & $5-10$ \\
\hline
\end{tabular}




\subsection{CARACTERÍSTICAS MORFOLÓGICAS E MINERALÓGICAS DO FOSFOGESSO}

Taha et al. (1995) cita que análises mineralógicas revelaram que os cristais no fosfogesso são principalmente sulfato de cálcio di-hidratado $\left(\mathrm{CaSO}_{4} \cdot 2 \mathrm{H}_{2} \mathrm{O}\right)$, com a presença de outros elementos em proporções menores.

Os estudos realizados por Taha et al. (1995), com o auxílio de microscópios óticos e eletrônicos, mostraram que o fosfogesso apresenta-se como partículas em forma de aglomerado lamelar. Alguns materiais mais expostos aos efeitos de intempéries tendem a apresentar partículas mais densas e arredondadas.

Mangin (1978) cita que em estudo sobre a morfologia dos cristais de fosfogesso, foi possível distinguir quatro formas características de cristais, dependentes do mineral usado na produção do ácido e do processo de produção:

- Cristais aciculares, que apresentam dimensões variando de - L: $80 \mu \mathrm{m}$ a $500 \mu \mathrm{m}$; I: $20 \mu \mathrm{m}$ a $100 \mu \mathrm{m}$; e: $20 \mu \mathrm{m}$ a $100 \mu \mathrm{m}$; onde L corresponde à maior dimensão da partícula, I corresponde à dimensão intermediária da partícula e, e corresponde à menor dimensão ou espessura da partícula;

- Cristais tabulares, que apresentam dimensões variando de - L: $40 \mu \mathrm{m}$ a 200 $\mu \mathrm{m} ; \mathrm{I}: 30 \mu \mathrm{m}$ a $150 \mu \mathrm{m}$; e: $5 \mu \mathrm{m}$ a $10 \mu \mathrm{m}$;

- Os cristais compactos, que são os cristais tabulares nos quais a espessura atinge dezenas de microns;

- Agregados policristalinos, que são um conjunto de cristais em forma de "ouriço", e que podem ser circunscritos por uma esfera de $50 \mu \mathrm{m}$ a $100 \mu \mathrm{m}$ de diâmetro

Nas considerações de Guttil et al. (1996), a estrutura cristalina do fosfogesso consiste em sua maior parte de cristais tabulares que correspondem, em média, a $90 \%$ do total. Em misturas estabilizadas contendo fosfogesso, os cristais podem ser identificados pelo formato tabular característico e por suas faces polidas. Taha et al. (1995) argumentaram que 
os cristais do fosfogesso bruto tornam-se mais densos e amorfos, em função da idade do depósito em que se encontra e dos fenômenos de lixiviação.

\subsection{CARACTERÍSTICAS RADIOLÓGICAS}

O fosfogesso apresenta na sua composição partículas de elementos radioativos provenientes das rochas fosfáticas que lhe deram origem. Os radionuclídeos urânio-238, $\left({ }^{238} \mathrm{U}\right)$, rádio-226 $\left({ }^{226} \mathrm{Ra}\right)$, radônio-222 $\left({ }^{222} \mathrm{Rn}\right)$ são os elementos mais comuns encontrados no fosfogesso que, juntamente com outros poluentes deste resíduo tais como urânio $(U)$, tório $(T h)$ e o polônio (Po), são alvos de questões ambientais relacionadas aos riscos de contaminação de solos, mananciais de água, poluição atmosférica. Entre os elementos mais preocupantes presentes no fosfogesso estão o ${ }^{238} \mathrm{U}$, o ${ }^{234} \mathrm{U}$ e os produtos do decaimento do urânio (TAKEDA, 1998).

Diversos estudos realizados, principalmente pelo FIPR (Florida Institute of Phosphate Research), dão conta da importância de se avaliar os efeitos da exposição humana e do meio-ambiente à radiação produzida pelo fosfogesso. Entre esses estudos pode-se citar TREFLER et al. (1988), CHIN (1988), BERISH (1990), ROESSLER (1990), WALSH (19990), JOHNSON \& TRAUB (1996), JAMES (1996).

Radionuclídeo é uma espécie atômica específica com certa composição nuclear dada de um elemento químico com propriedades radioativas.

Os elementos contaminadores emanados das pilhas de fosfogesso promovem prejuízos ao meio ambiente e à saúde humana. As fontes de contaminação incluem: a lixiviação de água para os aqüiferos subterrâneos e para os sistemas de água superficial; a difusão gasosa de radônio $\left({ }^{222} \mathrm{Rn}\right)$ pelo ar; partículas de radionuclídeos em suspensão no ar; e irradiação direta de radiação gama $(\Upsilon)$. Os riscos de contaminação do meio ambiente e os riscos à saúde humana descrevem em função da distância das pilhas. Todas essas informações foram obtidas a partir do estudo realizado por Berish (1990).

A preocupação com as emanações radioativas do fosfogesso teve seu ápice em 1992 quando a entidade americana EPA (Environmental Protection Agency), agência de proteção ambiental dos Estados Unidos, regulamentou a 
disposição do fosfogesso, permitida apenas em pilhas ou minas monitoradas, proibindo o seu uso na construção rodoviária e restringindo a sua aplicação na agricultura a materiais contendo até $10 \mathrm{pCig}^{-1}$ de ${ }^{226} \mathrm{Ra}$. Limitou também, a quantidade de fosfogesso que poderia ser usada em qualquer pesquisa e projeto em desenvolvimento a $317,50 \mathrm{~kg}(700 \mathrm{lb})$.

O instituto de fertilizantes (TIF - The Fertilizer Institute), baseado na constatação de um provável erro de cálculo que levou à superavaliação dos riscos à exposição ao fosfogesso, obteve a reconsideração dessa limitação, que foi revista ainda em 1992, permitindo o uso de 1587,6 kg (3500 lb) em pesquisas e projetos em desenvolvimento. Permitiu-se também o uso do fosfogesso para aplicações na agricultura e construção, desde que observada a redução apropriada da concentração de ${ }^{226}$ Ra a limites aceitáveis (TAKEDA, 1998).

Para se verificar se um fosfogesso, com uma concentração típica de 26 $\mathrm{pCig}^{-1}$ de ${ }^{226} \mathrm{Ra}$, poderia ou não ser usado na agricultura ou construção sem regulamentação própria, a EPA adotou um critério para se estimar o risco máximo adicional a um indivíduo que estivesse exposto à radiação do fosfogesso, que não poderia exceder $3 \times 10^{-4}$. Para avaliação desse risco, a EPA considerou vários cenários hipotéticos para definir a exposição razoável máxima (MRE - Maximum Reasonable exposure) à radiação produzida pelo fosfogesso em aplicações na agricultura e construção. Na construção rodoviária, o cenário mais crítico indicou um risco máximo de $9,3 \times 10^{-3}$ para um indivíduo que morasse durante 70 anos em uma casa construída sobre uma rodovia abandonada executada utilizando-se fosfogesso, e onde o leito da rodovia estivesse intacto (JAMES, 1996; JOHNSON \& TRAUB, 1996).

Esses resultados são constatados num estudo realizado por Johnson \& Traub (1996), que recalcularam os riscos individuais para a totalidade dos cenários contemplados pela EPA. Os riscos variaram de $6,2 \times 10^{-5}$ a $8,1 \times 10^{-5}$, estando, portanto, dentro do limite de risco individual máximo admitido pela EPA.

James (1996) ainda contesta os critérios da EPA para estabelecer um risco individual adicional aceitável de $3 \times 10^{-4}$, comparando o risco de vida diário de uma pessoa que escolhesse viver durante toda a sua existência em 
uma casa construída sobre uma velha rodovia que tenha incorporado fosfogesso na sua construção, com a de outras situações de risco:

- O risco de se morrer em um acidente aéreo é quase o mesmo;

- O risco de se morrer prematuramente de câncer causado pelo radionuclídeo natural potássio $40\left({ }^{40} \mathrm{~K}\right)$, presente no nosso corpo, é duas vezes maior;

- O risco de se morrer em um incêndio em casa é três vezes maior;

- O risco de morte por afogamento é sete vezes maior;

- O risco de morte em um acidente de carro é vinte e cinco vezes maior;

- O risco de ser vítima de um assassinato é vinte e sete vezes maiores.

Deve-se considerar que esses exemplos de morte violenta implicam em uma redução substancial do tempo de vida.

\subsection{APLICAÇÃO DO FOSFOGESSO}

O fosfogesso tem competido economicamente com o gesso natural principalmente em países onde não ocorrem jazidas desse mineral, como por exemplo, o Japão.

Para diminuir os expressivos volumes e custos de depósitos de fosfogesso gerado durante a fabricação do ácido fosfórico pelas indústrias de fertilizantes, são propostas várias práticas de uso desse resíduo, como por exemplo, em construção de bases e sub-bases rodoviárias e outros propósitos que serão citados nos itens 2.10.1, 2.10.2, 2.10.3 e 2.10.4.

\subsection{1 $\mathrm{Na}$ agricultura}

A utilização de novas técnicas de manejo do solo pode produzir uma melhora significativa nos fatores limitantes de seu uso para fins agrícolas. Dentro desse contexto, têm sido desenvolvidos vários estudos sobre o uso agrícola do fosfogesso, verificando-se que uma grande variedade de frutas, legumes, forragem, sementes oleosas e grãos, cultivados em solos tratados com esse material, têm apresentado aumento na qualidade do produto e na quantidade colhida. 
Pesquisas sobre a aplicação do fosfogesso têm mostrado resultados positivos de sua atuação, principalmente, como fonte de cálcio e enxofre, na correção de solos sódicos (com sais de sódio) e na correção de solos ácidos.

Grande parte dos solos brasileiros apresenta deficiência em cálcio (MG, RJ, RS, SP) e enxofre (GO, MG, MS, PR, SP), conduzindo a limitações consideráveis das colheitas, pela carência crescente desses nutrientes.

Foram feitas em São Paulo, várias avaliações da influência do uso do fosfogesso para as culturas de soja e feijão, em vários tipos de solo, mostrando que houve incremento de $28 \%$ a $37 \%$ na produtividade da soja, enquanto o feijão apresentou um aumento de produção variando de $13 \%$ a $54 \%$.

Outras culturas foram estudadas com relação à utilização do fosfogesso como fonte de enxofre e cálcio, destacando-se, no caso do cálcio, o amendoim, que aparece como a cultura anual mais promissora.

\subsection{2 $\mathrm{Na}$ indústria química}

O fosfogesso costuma ser muito utilizado nas indústrias químicas, entre elas, nas indústrias de cimento, de papel, na recuperação de enxofre e também nas indústrias de ácido sulfúrico.

\subsubsection{Indústria de cimento}

Damasceno (1994), o sulfato de cálcio é usado como um aditivo do Cimento Portland, com a função de controlar o tempo de pega do cimento. $O$ fosfogesso, por constituir-se de $\mathrm{CaSO}_{4} .2 \mathrm{H}_{2} \mathrm{O}$, torna-se numa alternativa muito interessante de reaproveitamento para a indústria do cimento, diminuindo as pilhas de fosfogesso. Porém, devido à suas impurezas, a transformação do fosfogesso em matéria-prima do cimento exige que se faça um tratamento de purificação - beneficiamento. Na fabricação do cimento, este resíduo industrial beneficiado substitui a gipsita ou anidrita natural na fabricação do Cimento Portland, para atuar como aditivo do clinquer do mesmo ou retardador de pega. A gipsita, matéria prima da fabricação do gesso comum é constituída de $\mathrm{CaSO}_{4} 2 \mathrm{H}_{2} \mathrm{O}$ e é geralmente acrescida de uma certa proporção de impurezas, como $\mathrm{SiO}_{2}, \mathrm{Al}_{2} \mathrm{O}_{3}, \mathrm{Fe}_{2} \mathrm{O}_{3}$ e carbonatos de cálcio. Portanto, para o fosfogesso 
passar a ser utilizado como substituto à gipsita e anidrita natural na fabricação do cimento, deve passar por um tratamento de purificação - beneficiamento.

As jazidas nacionais de gipsita estão localizadas nas regiões norte e nordeste do Brasil, especialmente nas Chapadas do Araripe e Apodi. Porém, nessas regiões não existem indústrias de fertilizantes fosfatados e, por conseqüência, o fosfogesso. Por esse motivo, a aplicação desse resíduo ainda não se torna muito viável na indústria química dessas regiões.

As indústrias de cimentos dos estados como São Paulo, Paraná, Santa Catarina e Rio Grande do Sul, podem usar o fosfogesso por se situarem em pontos mais próximos das unidades de produção das indústrias de fertilizantes fosfatados, facilitando o reaproveitamento do fosfogesso.

Há uma estimativa de uso de aproximadamente 400.000 t/a a 500.000 t/a de fosfogesso pelas indústrias de cimento brasileira, representando em torno de $10 \%$ do total de fosfogesso produzido.

Como comparação ao reaproveitamento do fosfogesso nesse setor em outros países, Mohammad (1998) comenta que somente 15\% de resíduo produzido na Jordânia é utilizado na indústria do cimento como controlador do tempo de pega.

\subsubsection{Cargas minerais funcionais na indústria de papel.}

Pesquisas realizadas no centro de Tecnologia da Serrana S.A. de Mineração mostraram ser possível a utilização do fosfogesso na indústria de papel, plásticos e tintas. Porém, certas impureazas devem ser removidas antes dessa reutilização.

O material deve passar por operações de beneficiamento ou processamento mineral, para remoção de impurezas (silicatos, óxidos etc). Deverá obter do material, as distribuições granulométricas adequadas para gerar carga mineral de excelente qualidade (WATER, 1989).

\subsubsection{Recuperação do enxofre}

O fosfogesso fornece dióxido de enxofre $\left(\mathrm{SO}_{2}\right)$, devido à presença de sulfato na sua composição. A dessulfurização é a decomposição térmica do 
fosfogesso em presença de uma fonte de carbono (geralmente coque de petróleo ou carvão mineral), argila fosfática residual, bentonita, pirita e aditivos químicos de menor importância para ativar a reação entre tais componentes, (SILVESTRE, 20002). Taha \& Seals (1991) e Foxworthy et al (1996) explicaram que as reações dessas misturas ocorrem dentro de fornos circulares, rotativos e aquecidos a uma temperatura que varia em torno de $2700^{\circ} \mathrm{F}\left(1482^{\circ} \mathrm{C}\right)$, com formação do gás $\mathrm{SO}_{2}$, matéria prima para a produção do ácido sulfúrico.

Cerca de $68 \%$ do enxofre usado como ácido sulfúrico na fabricação de fertilizantes fica retido no fosfogesso. Para os países carentes de reservas naturais dessa matéria prima, torna-se atrativa a recuperação desse enxofre, pois 6 toneladas de fosfogesso contêm cerca de 1 tonelada de enxofre recuperável. A recuperação pode ser feita por três vias: produção de sulfato de amônio, de ácido sulfúrico ou de enxofre elementar.

\subsubsection{Na construção civil}

$\mathrm{Na}$ indústria da construção civil, o fosfogesso pode substituir o gesso natural, na fabricação de placas, blocos e painéis, na produção de gesso e na fabricação de agregados para concreto.

A presença de flúor e enxofre nesse resíduo, em alguns casos, pode limitar essa utilização, por ter reflexo no tempo de endurecimento da pasta de gesso ou, no caso do cimento, do tempo de pega do concreto. Outro aspecto a ser avaliado é a presença de umidade excessiva, que pode inviabilizar o uso econômico do fosfogesso, devido ao aumento de consumo de energia para secagem do material.

\subsubsection{Fabricação de painéis, placas e blocos}

A utilização do fosfogesso na fabricação de painéis, placas e blocos é bastante difundida em alguns países como a Áustria, a Holanda e a Bélgica. A fabricação de blocos, placas e painéis e o uso em argamassas ainda não apresenta importância comercial. No Brasil, o fosfogesso já vem substituindo o gesso natural para a fabricação destes produtos. 


\subsubsection{Produção de gesso}

O fosfogesso pode transformar-se em gesso comum, a partir de um processo de beneficiamento, e posteriormente ser usado na manufatura de artefatos pré-moldados, painéis para paredes e blocos de alvenaria.

O beneficiamento do fosfogesso demanda custos e sua viabilidade de uso está condicionada a aspectos econômicos, como a facilidade de se encontrar o resíduo e a competitividade com o gesso natural.

\subsubsection{Fabricação de agregado para concreto}

Nos trabalhos de Foxworthy et al. (1994, 1996), foram avaliadas as características físicas, químicas, morfológicas e mecânicas desse agregado, usando-se os métodos convencionais de ensaio de caracterização de agregados para construção civil. O objetivo do primeiro trabalho foi avaliar seu desempenho em concreto de cimento Portland e do segundo trabalho foi verificar seu comportamento em misturas com cimento asfáltico a quente.

No estudo feito por Foxworthy et al. (1996), os grãos do fosfogesso apresentam um formato irregular com arestas vivas, superfície áspera e porosa. Sua granulometria está ilustrada na Figura 2.4, onde se percebe que o resíduo possui deficiência de agregados finos, necessitando da adição desses agregados para que possa se enquadrar dentro das faixas granulométricas normalizadas para misturas asfálticas (TAHA \& SEALS, 1992).

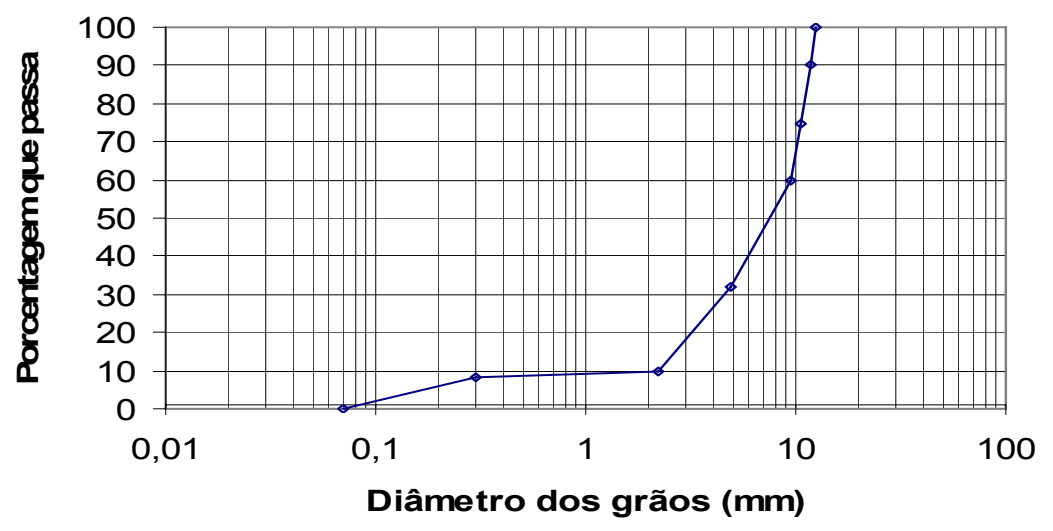

FIGURA 2.4 - Distribuição granulométrica do agregado sintetizado pelo processo de obtenção do dióxido de enxofre do fosfogesso (adaptado de Taha \& Seals, 1992) 


\subsubsection{Na pavimentação}

O fosfogesso é utilizado compactado, puro ou misturado com outros materiais de uso comum como, por exemplo, solo, areia, cal e cimento. $\mathrm{O}$ fosfogesso pode ainda ser usado com outros tipos de materiais não convencionais, como é o caso da cinza volante para a construção de camadas de pavimentos rodoviários. No Brasil, Ortiz, (1997), Takeda, (1998), Kobayashi, (2000), Parente (2002) e Silvestre (2002), realizaram trabalhos com este tipo de resíduo para reuso na construção rodoviária. Nos parágrafos a seguir serão descritas as propriedades do fosfogesso puro compactado e do fosfogesso misturado com outros materiais. Os estudos realizados com o fosfogesso na pavimentação têm como foco base, o reaproveitamento deste resíduo para utilização em bases e sub-bases rodoviárias.

\subsection{FOSFOGESSO COMPACTADO}

Várias pesquisas foram realizadas, dentre elas pode citar Chang \& Mantell (1990), com relação às propriedades mecânicas e físicas do fosfogesso puro compactado, para utilização em camadas de pavimentos rodoviários na qual, foram analisadas, a massa específica seca, umidade ótima, resistência mecânica, expansibilidade e deformabilidade, visando a sua aplicação em obras de engenharia e uso como material de construção.

A maior parte dos estudos tem mostrado que a resistência do fosfogesso depende de seu tipo e dos procedimentos e condições de estabilização. $O$ fosfogesso anidro, quando compactado, desenvolve uma parcela de resistência através da aglutinação de suas partículas ao reagirem quimicamente com a água, contribuindo, dessa forma, para sua estabilidade. Nos tipos de fosfogesso hemi-hidratado e di-hidratado, a sua resistência ocorre exclusivamente por estabilização mecânica, mediante compactação (SILVESTRE, 2002).

O fosfogesso compactado, principalmente o di-hidratado, apresenta bons índices de resistência quando não submetido à imersão em água. Já na condição imersa, o material encontra-se instável, necessitando da adição de estabilizantes químicos. Os principais trabalhos que se encontram em destaque com relação às análises do fosfogesso compactado são os de Chang \& Mantell 
(1990), Lin apud Chang \& Mantell $(1990)^{3}$, Taha \& Seals (1991) e Maccarini (1991), (SILVESTRE, 2002).

Ho \& Zimpfer apud Taha \& Seals $(1991)^{4}$ realizaram ensaios de compactação Proctor normal e Proctor modificado. Comparando os resultados pelos pesquisadores, os mesmos chegaram à conclusão de que os valores de massa específica seca máxima ( $\left.\rho_{\text {dmáx }}\right)$ e umidade ótima $\left(\omega_{0}\right)$ apresentaram diferenças entre si para a mesma energia de compactação. Os autores atribuíram esse fato à diversidade das origens das amostras de fosfogesso ensaiadas. Na energia equivalente ao Proctor normal, os valores de $\rho_{\text {dmáx }}$ variaram de $1,334 \mathrm{~g} / \mathrm{cm}^{3}$ (83pcf) a $1,522 \mathrm{~g} / \mathrm{cm}^{3}$ (95pcf) e $\omega_{\circ}$ de $12,8 \%$ a $21,6 \%$. $\mathrm{Na}$ energia Proctor modificado, $\rho_{\mathrm{dmáx}}$ variou entre $1,447 \mathrm{~g} / \mathrm{cm}^{3}$ (90,3pcf) e $1,618 \mathrm{~g} / \mathrm{cm}^{3}$ (101pcf) e $\omega_{0}$ entre $15 \%$ e 18,4\%. Verificou-se também que, para amostras de mesma origem, a aplicação da energia equivalente ao Proctor modificado na compactação conduziu a valores de $\rho_{\text {dmáx }}$ maiores e de $\omega_{0}$ menores em relação aos valores obtidos na energia Proctor normal. Isto já era previsto, pois amostras compactadas na energia equivalente ao Proctor modificado apresentam valores superiores de $\rho_{\text {dmáx }}$ e valores inferiores de $\omega_{\circ}$ se comparado com os obtidos com a energia equivalente ao Proctor normal. Observou-se também que a adição de cinza volante ou cimento Portland ao fosfogesso, conduz a aumentos de $\rho_{\text {dmáx }}$ e $\omega_{0}$.

$\mathrm{Na}$ Tabela 2.13 consta o resumo dos resultados dos ensaios de compactação Proctor normal e Proctor modificado feitas por Ho \& Zimpfer apud Chang \& Mantell $(1990)^{5}$ de fosfogessos coletados das companhias de fertilizantes W.R. Grace, Amax, Occidental 1, Gardinier, Occidental 2, Conserv e I.M.C., localizadas no Estado da Florida.

\footnotetext{
${ }^{3}$ LIN, K.; FIGUEROA, J. L.; CHANG, W. F. (1985). Engineering Properties of Phosphogypsum. PROCEEDINGS OF THE SECOND WORKSHOP ON BY-PRODUCTS OF PHOSPHATE INDUSTRIES, Miami, Florida, May, 1985. p. 49-59.

${ }^{4}$ HO, R. K. H.; ZIMPFER, W. H., (1985). Coments on the Investigation of Phosphogypsum for Embankment Construction. PROCEEDINGS OF THE SECOND WORKSHOP ON BYPRODUCTS OF PHOSPHATE INDUSTRIES, Miami, Florida, May, 1985. p. 182-213.

${ }^{5}$ HO, R. K. H.; (1985). Comments on the Investigation of Phosphogypsum for Embankment Construction. PROCEEDINGS OF OF THE SECOND WORKSHOP ON BY-PRODUCTS OF PHOSPHATE INDUSTRIES, Miami, Florida, May, 1985. p.182-213.
} 
TABELA 2.13 - $\rho_{d m a ́ x}$ e $\omega_{0}$ de fosfogessos di-hidratados produzidos na Florida (EUA), obtidas dos ensaios de compactação Proctor normal e Proctor modificado (adaptado de CHANG \& MANTELL, 1990)

\begin{tabular}{lcccc}
\multicolumn{1}{c}{ Energia de compactação } & \multicolumn{2}{c}{ Proctor normal } & \multicolumn{2}{c}{ Proctor modificado } \\
\hline Fonte industrial do fosfogesso & $\rho_{\text {dmáx }} \mathrm{g} / \mathrm{cm}^{3}$-pcf) & $\omega_{\circ}(\%)$ & $\left.\rho_{\text {dmáx }} \mathrm{g} / \mathrm{cm}^{3}-\mathrm{pcf}\right)$ & $\omega_{\circ}(\%)$ \\
\hline W.R. GRACE & $1,469-91,7$ & 12,8 & $1,555-97,1$ & 15,0 \\
AMAX & $1,329-83,0$ & 19,2 & $1,447-90,3$ & 18,4 \\
OCCIDENTAL 1 & $1,469-91,7$ & 18,9 & $1,477-92$ & 17,3 \\
GARDINIER & $1,522-95,0$ & 16,8 & $1,618-101,0$ & 14,1 \\
OCCIDENTAL 2 & $1,355-84,6$ & 21,6 & $1,467-91,6$ & 17,7 \\
CONSERV & $1,448-90,4$ & 19,1 & $1,520-94,9$ & 15,0 \\
I.M.C. & $1,472-91,9$ & 18,4 & $1,552-96,9$ & 16,4 \\
\hline
\end{tabular}

No Brasil, Maccarini (1991) estudou o comportamento mecânico de um fosfogesso di-hidratado obtido de uma indústria carboquímica catarinense. $\mathrm{O}$ fosfogesso foi avaliado na condição anidra e compactado na energia equivalente à do Proctor modificado. A desidratação do fosfogesso di-hidratado para seu estado anidro foi realizada através de seu aquecimento em estufa, a temperatura de $130^{\circ} \mathrm{C}$, durante 20 horas. A massa específica seca máxima para moldagem dos corpos de prova foi de $1,41 \mathrm{~g} / \mathrm{cm}^{3}$ e a umidade ótima de $28 \%$, determinadas no ensaio de compactação. O tempo de cura decorrido desde a moldagem até o instante do rompimento dos corpos de prova foi de 5 horas. Completado esse tempo, a realização dos ensaios de compressão simples procedeu-se de duas formas: uma parte dos corpos de prova foi ensaiada imediatamente após a cura e a outra parte ensaiada 10 dias depois de permanecerem imersos em água. A adoção do tempo de 10 dias foi baseada no trabalho anterior de Trichês \& Maccarini (1988), onde foi constatada que a perda de resistência do fosfogesso frente à imersão foi mais acentuada durante esse período, quando o grau de saturação do corpo de prova atingiu $100 \%$.

Os resultados de resistência do fosfogesso ensaiados sem imersão foi de ordem de $12,7 \mathrm{MPa}$, sofrendo queda de $10 \%$ na situação de ensaio após imersão.

Em experimento realizado por Maccarini (1991), foi avaliada a evolução de crescimento da resistência à compressão simples, em pequenos tempos de cura (até 50 horas). Os resultados obtidos mostraram que o tempo de cura de 8 
horas forneceu ao fosfogesso quase a totalidade de sua resistência, com sua metade sendo alcançada em 2 horas.

Estudos realizados com o fosfogesso do tipo di-hidratado de 8 diferentes fontes, propôs avaliar a resistência à compressão simples utilizando-se na preparação dos corpos de prova dois métodos de compactação: dinâmica e estática. Cada método foi escolhido com o objetivo de simular um procedimento típico de compactação de materiais empregados em obras de engenharia. Sabe-se, por exemplo, que a compactação dinâmica é tradicionalmente utilizada sobre materiais de camadas rodoviárias, enquanto que a compactação estática tem fundamental importância na fabricação de peças pré-moldadas, como blocos de alvenaria ou de calçamento, em que determinados materiais são submetidos a elevadas pressões de compactação alcançadas somente em instalações industriais.

Com relação aos efeitos da compactação estática e dinâmica, pode ser afirmado que, os efeitos da compactação estática são semelhantes aos encontrados na compactação dinâmica, ou seja, os fatores que governam o comportamento da resistência à compressão simples do fosfogesso compactado (energia de compactação, tempo e condição de cura) são os mesmos para os dois tipos de compactação: estática e dinâmica. Lin et al. apud Chang \& Mantell $(1990)^{6}$ e Lin apud Chang \& Mantell (1990) ${ }^{7}$ relataram que o aumento da pressão de compactação estática aplicada aos corpos de prova de fosfogesso fornece, em geral, aumentos de resistência e de massa específica seca máxima. Para uma mesma pressão de compactação, os corpos de prova ensaiados sem imersão apresentaram resistências maiores que dos ensaiados após imersão em água. Um fato especial ocorreu com relação ao fosfogesso fornecido pela empresa USS, pois todos os corpos de prova sofreram colapso na condição imersa, (SILVESTRE, 2002).

Das considerações de Chang \& Mantell (1990), destaca-se que os corpos de prova compactados estaticamente são instáveis na presença de

\footnotetext{
${ }^{6}$ LIN, K. (1987). Basic Engineering Properties of Phosphogypsum-Based Mixtures Subject to Compaction. Ph D. Dissertation, University of Miami, Coral Gables, Florida. May, 1987. 192p.

${ }^{7}$ LIN, K.; FIGUEROA, J. L.; CHANG, W. F. (1985). Engineering Properties of Phosphogypsum. PROCEEDINGS OF THE SECOND WORKSHOP ON BY-PRODUCTS OF PHOSPHATE INDUSTRIES, Miami, Florida, May, 1985. p. 49-59.
} 
água quando sua pressão de compactação for inferior a 5,1MPa (750psi). As principais soluções, nesse caso, seria utilizar pressões maiores ou adicionar ao fosfogesso um material estabilizante, como por exemplo, o cimento Portland.

A maioria das pesquisas constataram que o fosfogesso bruto compactado não é adequado para ser usado na construção de bases e subbases de pavimentos rodoviários, por não apresentar estabilidade necessária perante a ação da água. Por outro lado, seu uso torna-se viável na construção civil, para fabricação de tijolos, painéis e blocos, desde que sobre eles sejam aplicadas pressões de compactação estática suficiente para que o produto final tenha a resistência mecânica desejada para uso comercial (CHANG \& MANTELL, 1990; TAHA \& SEALS, 1991).

\subsection{MISTURAS CONTENDO FOSFOGESSO}

Os principais tipos de misturas compactadas contendo fosfogesso e outros materiais, com vistas aos seus empregos em pavimentação encontramse em estudos misturas com cimento, solo, cinza volante, e concreto compactado rolado. Na literatura são relatadas pesquisas que abrangem desde trabalhos em laboratório até 0 monitoramento de pistas experimentais construídas com esses materiais. Revisões mais detalhadas sobre as outras misturas contendo o fosfogesso, podem ser encontradas nas dissertações de Ortiz (1997), Takeda (1998), Kobayashi (2000), Parente (2002) e Silvestre (2002), elaboradas na EESC/USP.

\subsubsection{Misturas de fosfogesso e cimento}

Gregory et al. (1984), Saylak et al. (1988), Chang \& Mantell (1990), Gadalla et al. (1990), Taha \& Seals (1991), Taha et al. (1992), Ong et al. (1994), Gerrity et al. (1994), Tittlebaum et al. (1995), Gutti et al. (1996), Takeda (1998), Kobayashi (2000), Silvestre (2002), Parente (2002), são exemplos de pesquisadores que se dedicaram ao estudo de misturas compactadas contendo fosfogesso e cimento.

O fosfogesso compactado não apresenta estabilidade frente à ação da água, necessitando de tratamentos que proporcionem melhorias em suas características mecânicas para que possa ser usado em construção rodoviária. 
Os trabalhos supracitados relatam as propriedades mecânicas do fosfogesso estabilizado com cimento e os fatores que as influenciam, tais como teor e tipo de cimento, energia de compactação, tempo, condição de cura, $\mathrm{pH}$ e expansibilidade.

Pesquisas realizadas com estes materiais constataram que o fosfogesso estabilizado com cimento pode ser utilizado como material para execução de base e sub-bases rodoviárias. Nota-se também que o teor e tipo de cimento, energia de compactação, período de cura e acidez $(\mathrm{pH})$ têm influência marcante no comportamento da mistura.

Com relação à análise de resistência à compressão simples de misturas de fosfogesso e cimento, Gregory et al. (1984) em sua pesquisa utilizaram um fosfogesso di-hidratado fornecido pela "Mobil chemical Company" originário de três depósitos diferentes, denominados pilhas 1, 2 e 3. Esse sistema de numeração está relacionado com a idade das pilhas, sendo a número 1 , a mais velha e considerada inativa. As pilhas 2 e 3, na época em que a pesquisa foi realizada eram consideradas ativas, ou ainda em uso. O critério de escolha das pilhas com idades diferentes baseou-se em avaliar se a mesma interfere na resistência à compressão simples.

Pesquisas iniciais, utilizando material da pilha 3, produziram misturas com baixa resistência à compressão. Já os estudos realizados com fosfogesso da pilha 2 produziram misturas com características de resistência à compressões mais aceitáveis. Este fato deve-se ao $\mathrm{pH}$ do fosfogesso, pois enquanto o $\mathrm{pH}$ do material proveniente da pilha 3 era 2,5, o encontrado no material da pilha 2 era de 5,2 .

As pesquisas realizadas pela "Texas A\&M University" com o fosfogesso da "Mobil chemical Company" mostraram que a resistência alcançada com a estabilização por cimento Portland obteve melhores resultados em depósitos inativos, com 7 anos de idade, do que em depósitos ativos. Portanto, nesta pesquisa chegou-se a conclusão que a acidez do material parece ser um fator que exerce influência primordial na resistência, refletindo no $\mathrm{pH}$. Os depósitos ativos, com pH aproximadamente de 2,5 desenvolveram pouca ou nenhuma resistência à compressão, enquanto que os depósitos de pilhas mais velhas $(\mathrm{pH} 5,2)$, mostraram um alto grau de estabilização, como ilustra a Figura 2.5. A 
distribuição granulométrica bem como a forma das partículas apresentou maiores variações no fosfogesso de pilhas mais velhas. Essas características permitem, por si só, a obtenção de maiores densidades e estabilidade, através de uma melhor compactação, (SAYLAK et al. 1988).

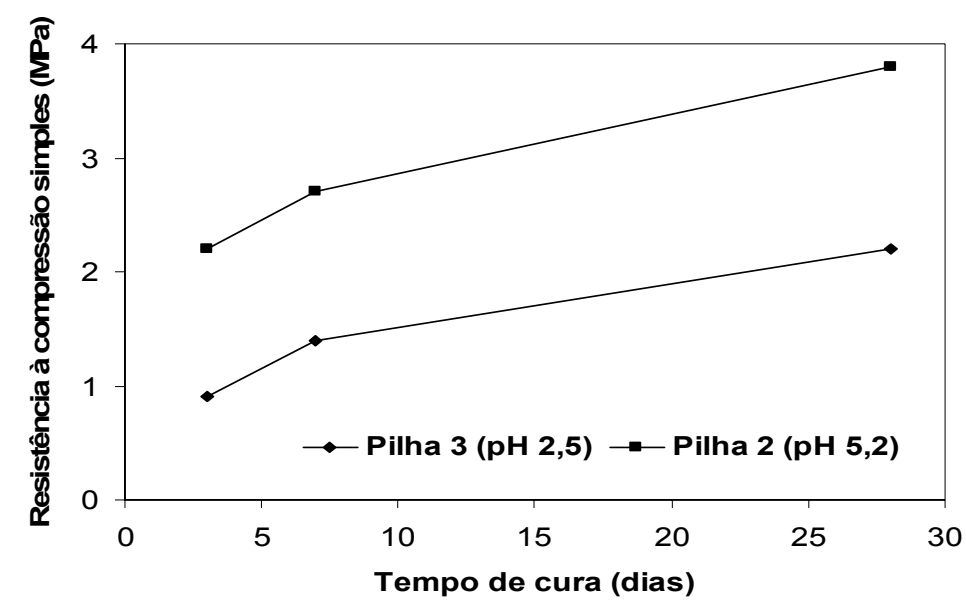

FIGURA 2.5- Comparação entre a resistência à compressão simples de fosfogesso estabilizado com $6 \%$ de cimento em função do tempo de cura e pH (fonte: adaptado de SAYLAK et al., 1988)

Com relação à resistência à compressão simples, o pH influencia no desenvolvimento da mesma na medida em que uma parcela do cimento, adicionado para melhorar as características de resistência, será consumida na neutralização do fosfogesso mais ácido (TAKEDA, 1998).

Gregory et al. (1984) na segunda fase de seus estudos, utilizaram misturas de fosfogesso da pilha $2 \mathrm{com}$ teores de cimento de $3 \%, 6 \%$ e $10 \%$. As misturas foram compactadas na energia equivalente ao Proctor modificado. Neste trabalho verificou-se que a resistência à compressão simples aumenta à medida que aumenta o teor de cimento e o tempo de cura.

Foi observado que os valores da resistência à compressão simples são diretamente proporcionais ao teor de cimento e ao tempo de cura. Segundo esses autores, nas argamassas convencionais de cimento e areia, os valores da resistência à compressão simples exigidos para um tempo de cura de 7 dias devem estar compreendidos entre 200 psi (1,38MPa) e 300psi (2,07MPa). 
Observou-se, para a totalidade das misturas de fosfogesso e cimento com o tempo de cura de 7 dias, valores superiores a 200 psi (1,38MPa).

Por não existir ainda normas específicas com relação à resistência à compressão simples mínima de misturas contendo fosfogesso e cimento, nas pesquisas realizadas com o fosfogesso, foram adotadas como valor de comparação o valor mínimo de resistência aos 7 dias de cura de argamassas convencionais de cimento e areia. Para este tipo de material, as resistências devem estar dentro do intervalo de 1,38 MPa (200 psi) a 2,07 MPa (300 psi). Os resultados mostraram que todas as misturas apresentaram resistência à compressão simples aos 7 dias de cura acima de 1,38 MPa, e que para teores de cimento de $6 \%$ e $10 \%$ os valores encontrados para a resistência à compressão simples foram superiores a 2,07 MPa.

Gerrity et al., 1994 estudaram a resistência à compressão simples de misturas de fosfogesso e cimento com teores de cimento variando entre $8 \%$, $10 \%$ e $12 \%$. Os corpos de prova foram submetidos aos ensaios com carregamento de velocidade constante de $1,3 \mathrm{~mm} / \mathrm{min}$. Foram usadas duas energias, uma próxima a normal e a outra com $95 \%$ da energia relativa à do Proctor modificado. Os períodos de cura foram de 7 dias e 28 dias. 0 comportamento das misturas de fosfogesso e cimento foram comparados com o comportamento das misturas de cimento e areia de rio. Os valores de resistência à compressão simples de alguns corpos de prova estão listados na Tabela 2.14.

TABELA 2.14 - Resistência à compressão simples fonte, (Gerrity et al., 1994)

\begin{tabular}{lcc}
\hline \multicolumn{1}{c}{ Material } & $\begin{array}{c}\text { Média de resistência à } \\
\text { compressão simples } \\
(\mathbf{k P a})\end{array}$ & $\begin{array}{c}\text { Desvio padrão } \\
(\mathbf{k P a})\end{array}$ \\
\hline $12 \% \mathrm{Cp}, \mathrm{Fg}$, normal, 7 dias & 452 & 48 \\
$10 \% \mathrm{Cp}, \mathrm{Ar}$, normal, 7 dias & 917 & 131 \\
$12 \% \mathrm{Cp}, \mathrm{Fg}, 95 \%$ modificado, 7 dias & 2331 & 338 \\
$12 \% \mathrm{Cp}, \mathrm{Fg}, 95 \%$ modificado, 28 dias & 3082 & 385 \\
$10 \% \mathrm{Cp}, \mathrm{Ar}, 95 \%$ modificado, 7 dias & 1469 & 210 \\
$10 \% \mathrm{Cp}, \mathrm{Ar}$, modificado, 7 dias & 1489 & 152 \\
\hline
\end{tabular}

* Cp-cimento portland; Ar-areia de rio; Fg-fosfogesso

Analisando os resultados apresentados na Tabela 2.14 pode-se concluir que para as misturas de fosfogesso e cimento compactadas com $95 \%$ da energia modificada e teor de cimento de $12 \%$ proporcionaram resistências à 
compressão simples superiores a 2,1MPa, resistência mínima para 7 dias de cura, conforme ABNT (NBR-1336, 1990). As misturas de areia de rio com 10\% de cimento, compactadas na energia normal e curadas no período de 7 dias mostraram resistências à compressão simples $49,3 \%$ acima das misturas de fosfogesso e $12 \%$ de cimento, compactadas e curadas nas mesmas condições.

Silvestre (2002) em pesquisa realizada na EESC/USP avaliou a influência do tipo de cimento na resistência e na deformabilidade das misturas de fosfogesso e cimento. Para alcançar o objetivo proposto foram escolhidos os seguintes teores de cimento para compor as misturas: $5 \%, 10 \%$ e $15 \%$ de cada tipo de cimento, em relação à massa seca de fosfogesso. Os corpos de prova foram compactados nas energias equivalente ao Proctor normal e modificado. Os corpos de prova após compactados tinham em média dimensões de $5 \mathrm{~cm}$ de diâmetro e $10 \mathrm{~cm}$ de altura e foram compactados estaticamente em três camadas. A metade das amostras foi ensaiada sem imersão e a outra metade, após imersão prévia em água, por 4 horas. 0 processo de cura dos corpos de prova consistiu em mantê-los em uma câmara úmida, com umidade relativa do ar controlada, por períodos de 1, 3, 7, 28, 84 e 210 dias.

Abstraindo o efeito do tempo de cura, comprovadamente marcante em misturas cimentadas, foi constado que a energia de compactação é a variável com maior influência no comportamento mecânico da mistura. Seguem, em ordem decrescente, as influências do teor de cimento, da imersão em água e do tipo de cimento. Foi destacado que a influência dessas variáveis ocorre segundo padrões muito semelhantes no tocante à resistência e à deformabilidade. Em todos os casos, valores crescentes de energia de compactação e de teores de cimento conduziram a maiores valores de resistência.

\subsubsection{Misturas de fosfogesso e solo}

Foram relatados alguns estudos contendo misturas compostas de fosfogesso e solo e seu emprego na construção rodoviária. Dentre esses estudos estão: a construção de duas pistas experimentais no estado da Florida (EUA), municípios de Polk e Columbia, (SILVESTRE, 2002). 
Para avaliar a possibilidade do uso dessa mistura na construção rodoviária, Zhou et al. Apud Chang \& Mantell (1990) ${ }^{8}$ e Maji et al. Apud Chang \& Mantell $(1990)^{9}$ estudaram algumas propriedades mecânicas de misturas compactadas de fosfogesso e solo, com diferentes proporções em massa de cada componente.

Zhou et al. Apud Chang \& Mantell (1990) submeteram corpos de prova de mistura fosfogesso e solo a ensaios de compactação, na energia equivalente ao Proctor modificado. Com essas análises, foram determinadas, a massa específica seca máxima e a umidade ótima da mistura. Posteriormente foram realizados os ensaios de compressão simples nas condições de massa específica seca máxima e umidade ótima.

Maji et al. Apud Chang \& Mantell (1990) pesquisaram o desempenho de misturas compostas de fosfogesso, areia e um tipo de solo areno-argiloso. A adição do solo teve a finalidade de diminuir o índice de vazios e fornecer um material ligante na mistura fosfogesso-areia. Os procedimentos e condições de ensaios foram similares aos realizados por Zhou et al. Apud Chang \& Mantell (1990), tanto para a determinação das curvas de compactação do ensaio de Proctor modificado quanto para o ensaio de compressão simples.

No Brasil, Ortiz (1997) desenvolveu, na Escola de Engenharia de São Carlos (EESC/USP), um trabalho usando a mistura fosfogesso e solo.

Ortiz (1997) realizou um estudo sobre a resistência à compressão simples de misturas de fosfogesso anidro e solo argiloso, compactadas na energia equivalente ao Proctor normal nos seguintes teores de umidade: umidade ótima $(\omega 0), \pm 1,5 \%$ e $(\omega 0) \pm 6 \%$. O estudo foi realizado no Departamento de Transportes da EESC/USP, onde foi utilizado um fosfogesso di-hidratado obtido da companhia de fertilizantes fosfatados FOSFÉRTIL. O fosfogesso foi submetido a uma temperatura de $130^{\circ} \mathrm{C}$ em estufa durante 24

\footnotetext{
${ }^{8}$ ZHOU, L.; FIGUEROA, J.; CHANG, W. F. (1986). Engimeering Properties of Phosphogypsum and Sand Mixtures for Secondary Roads. PROCEEDINGS OF THIRD WORKSHOP ON BYPRODUCTS OF PHOSPHATE INDUSTRIES, Miami, Florida, November, 1986, p. 285-313.

${ }^{9}$ MAJI, A.; FIGIUEROA, J.; CHANG, W. F. (1985) Engineering Properties of Phosphogypsum, Sand and Clay Mixtures. PROCEEDINGS OF SECOND WORKSHOP ON BY-PRODUCTS OF PHOSPHATE INDUSTRIES, Miami, Florida, May, 1985, p. 238-266.
} 
horas, de forma a convertê-lo em anidro. Na composição dessas misturas os teores de fosfogesso anidro foram de $0 \%, 20 \%, 40 \%, 80 \%$ e $100 \%$.

A resistência à compressão simples de misturas de fosfogesso e solo submetido à imersão prévia em água também foram estudadas. Os resultados dos ensaios indicaram que misturas de fosfogesso di-hidratado e solo não resistem a água, ou seja, eles se desmancham.

$\mathrm{Na}$ tentativa de se resolver o problema de estabilidade das misturas de fosfogesso di-hidratado e solo frente a ação da água, Figueroa et al. (1987) realizaram estudos com a adição de materiais betuminosos à mistura.

Foram estudadas misturas com diversos materiais betuminosos, tais como emulsões e asfaltos diluídos (cut-back). Entretanto, à exceção do asfalto diluído de cura rápida, CR-70, os resultados obtidos não foram satisfatórios.

Figueroa et al. (1987) realizaram estudos com cinco misturas diferentes, variando em função do teor de fosfogesso di-hidratado, solo e CR-70. As misturas foram compactadas na energia equivalente ao Proctor modificado. A Tabela 2.15 mostra as porcentagens das misturas utilizadas.

Essas misturas foram submetidas a ensaios com ciclos de imersão e secagem. Após o primeiro ciclo de imersão, as misturas sem CR-70 entraram em colapso, restando apenas as misturas com material betuminoso. Os resultados indicaram que, apesar de apresentarem um nível mais baixo de resistência à compressão após a imersão, a presença do CR-70 foi eficiente para a estabilização da mistura frente à ação da água.

TABELA 2.15 - Variação do teor de fosfogesso di-hidratado, solo e CR-70, FIGUEROA et al. (1987).

\begin{tabular}{ccc}
\hline Fosfogesso di-hidratado (\%) & Solo (\%) & CR-70 (\%) \\
\hline 33,3 & 66,6 & \\
25,0 & 75,0 & \\
33,3 & 66,6 & 1,0 \\
50,0 & 50,0 & \\
33,3 & 66,6 & 2,0 \\
\hline
\end{tabular}




\subsubsection{Misturas de Fosfogesso e cinza volante}

Entre os trabalhos com esse tipo de mistura para a utilização na construção rodoviária destacam-se os estudos realizados por Andriex et al. (1978), Taha \& Seals (1991).

A cinza volante é uma pozolânica artificial, resultante da combustão de carvão mineral em usinas termelétricas, finamente dividida que, em contato com hidróxido de cálcio, na presença de umidade, formam compostos aglomerantes análogos aos do cimento Portland (VAIDERGORIN, 1988).

Gregory et al. (1984) estudou misturas contendo fosfogesso e cinza volante. Numa análise preliminar do estudo, definiram-se alguns fatores que afetam a resistência das misturas de fosfogesso e cinza volante. Dentre estes fatores pode-se citar: energia de compactação, tempo de hidratação da cinza volante na presença de sulfato de cálcio, quantidade de água disponível para hidratação, o valor de $\mathrm{pH}$ e a disponibilidade de cal livre na cinza volante para iniciar a reação pozolânica.

Gregory et al. (1984) para a realização dos seus ensaios, usou corpos de prova compactados na energia equivalente ao Proctor modificado. Para compor a mistura foram utilizados 5 teores de cinza volante: $0 \%, 10 \%, 15 \%$, $20 \%$ e $30 \%$. Para cada teor de cinza volante, os corpos de prova foram submetidos a tempo de cura de 3,7 e 28 dias. A Figura 2.6 ilustra os resultados de resistência à compressão simples para a mistura de fosfogesso com os correspondentes teores de cinza volante.

Nos estudos realizados por Lin apud Chang e Mantell (1990) ${ }^{10}$ poderam chegar a conclusão de que mistura de fosfogesso e cal composta de 1\%, 3\% e $5 \%$ de cal aos 84 dias de cura com relação a resistência à compressão simples não apresentaram valores aceitáveis para ser utilizados em construção de bases de rodoviárias. Portanto, resolveram acrescentar cinza volante a mistura com a finalidade de obter melhores valores de resistência à compressão. Para compactar os corpos de prova, adotaram a energia equivalente ao Proctor normal, variando a porcentagem de cinza volante e mantendo constante o teor

\footnotetext{
${ }^{10}$ LIN, K.; FIGUEROA, J. L.; CHANG, W. F. (1985). Engineering Properties of Phosphogypsum. PROCEEDINGS OF THE SECOND WORSHOP ON BY-PRODUCTS OF PHOSPHATE INDUSTRIES, Miami, Florida, May, 1985. p. 49-80.
} 
de $5 \%$ de cal. Os teores de cinza volante e de fosfogesso utilizados respectivamente foram: $20 \%, 30 \%, 40 \%$ e $50 \%$ e $45 \%, 55 \%, 65 \%$ e $75 \%$. A Figura 2.7 ilustra o resultado da resistência à compressão simples destas misturas.

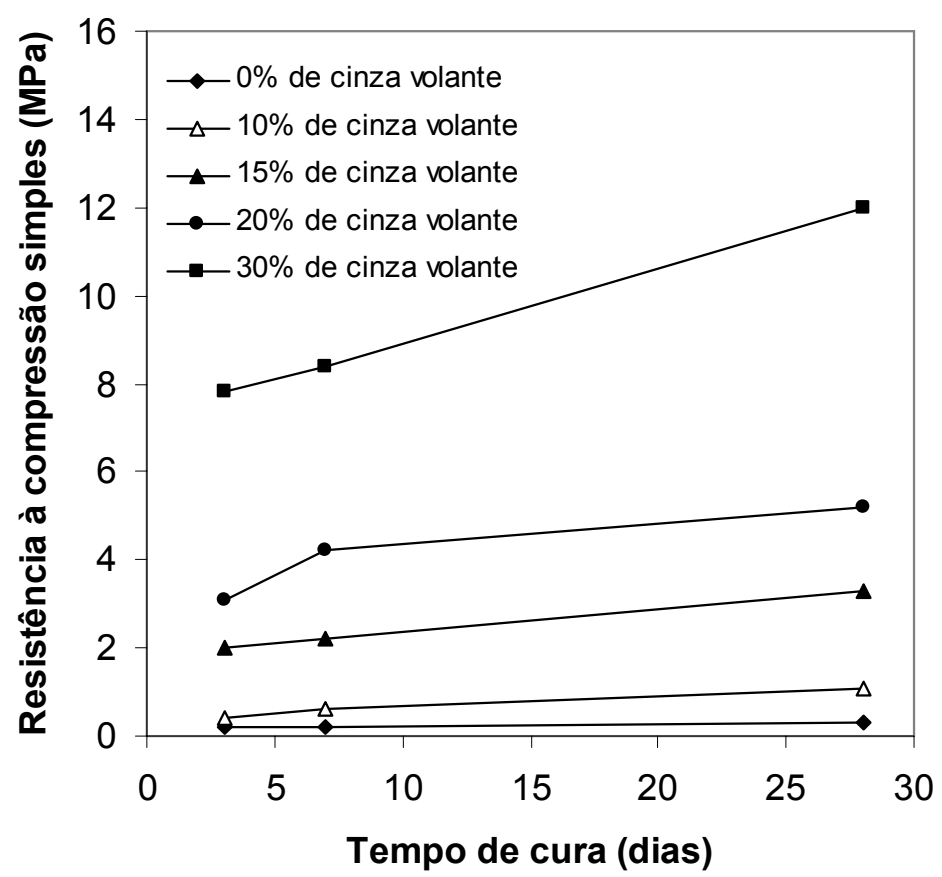

FIGURA 2.6 - Resistência à compressão simples para mistura de fosfogesso com os correspondentes teores de cinza volante, GREGORY et al. (1984)

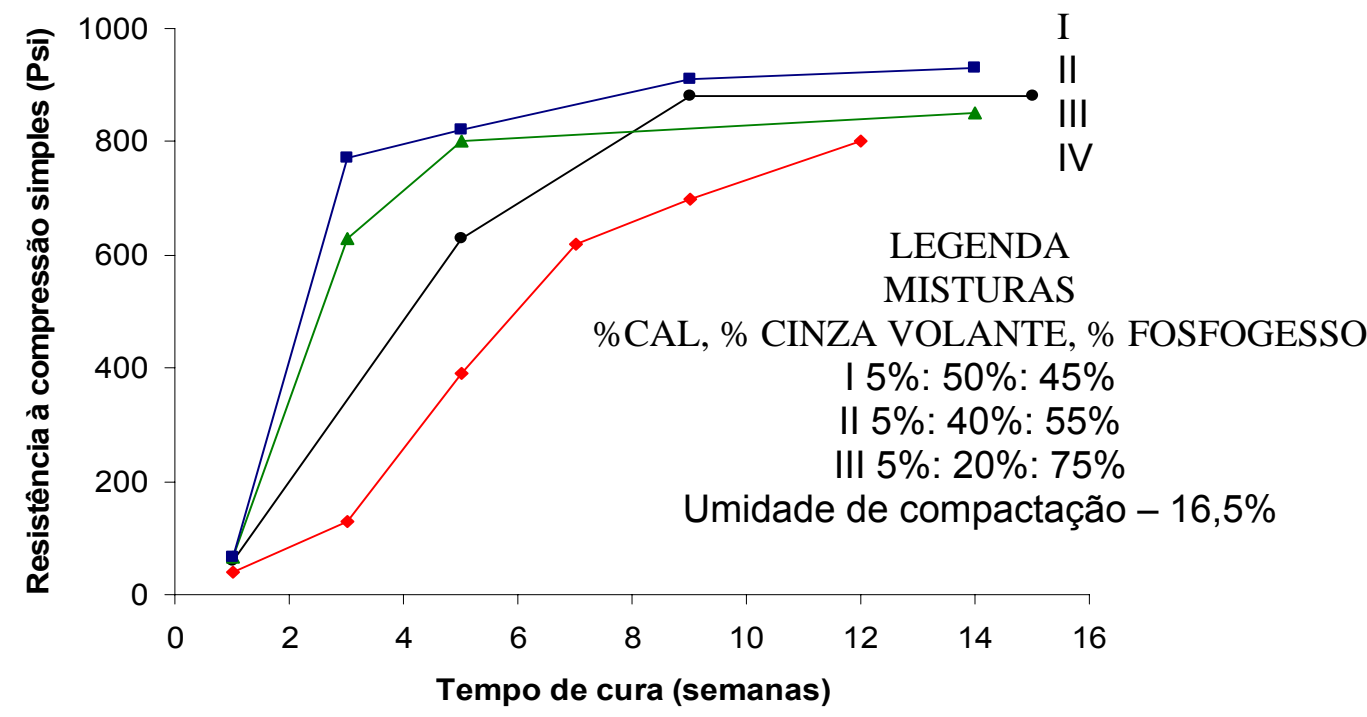

FIGURA 2.7 - Resistência à compressão simples $x$ tempo de cura em semanas, das diferentes misturas composta de cal, cinza volante e fosfogesso di-hidratado (Lin apud Mantell, 1990). 
Andrieux et al (1978), mostraram que os valores de resistência à compressão simples de misturas de fosfogesso e cinzas volantes não apresentaram bom desempenho para os tempos de cura de até 360 dias. Quando se adiciona cal às misturas de cinza volantes e fosfogesso, há um aumento na resistência à compressão simples, e esta resistência aumenta com o acréscimo no tempo de cura. O maior valor de resistência à compressão simples encontrada por estes pesquisadores foi de $35 \mathrm{MPa}$, o qual corresponde à mistura de $75 \%$ de cinza volante, $15 \%$ de cal e $10 \%$ de fosfogesso para um período de cura de 360 dias.

A partir de observações em pistas experimentais Usmen \& Moultom (1984) recomendam, que quando forem empregadas misturas de fosfogesso e cinza volante, é importante que as camadas do pavimento sejam executadas com um grau de compactação maior ou igual a 100\%. Com este grau de compactação podem-se obter valores de resistência à compressão simples elevados.

\subsubsection{Fosfogesso e concreto compactado rolado}

Pesquisadores tentando resolver o aspecto da reciclagem do fosfogesso, estudaram a possibilidade de substituir materiais finos por este resíduo industrial para ser usado em concreto rolado compactado. Dentre esses pesquisadores podem-se citar: CHANG (1988), NANNI \& CHANG (1989), CHANG \& MANTTEL (1990), TAHA \& SEALS (1991).

O concreto rolado é definido como uma mistura de cimento Portland, tendo como componentes a água, o cimento e agregados de granulometria grossa e fina, permitindo que o material seja espalhado no local da obra e compactado logo a seguir. Para a compactação são usados compactadores vibratórios de aço e pneu. Nesse tipo de mistura o fosfogesso pode substituir parcialmente ou completamente a fração fina (TAHA \& SEALS, 1991).

Taha \& Seals (1991) executaram projetos experimentais de campo empreendido pela Universidade de Miami onde foram construídas novas calçadas e áreas de estacionando pelo Instituto de pesquisa em fosfato, Bortow, Flórida (FIPR). 
A Tabela 2.16 apresenta as composições das misturas utilizadas no campo experimental, bem como os valores de resistência à compressão simples. As especificações determinam uma força de compressão de 2,500 psi, onde este valor encontra-se abaixo do permitido para aplicações em concreto rolado em pavimentos.

TABELA 2.16 - Proporções de Mistura de fosfogesso com concreto rolado compactado utilizadas no campo experimental para projeto de pavimento, Taha \& Seals (1991)

\begin{tabular}{ccc}
\hline Constituintes & Proporções (\% em peso) & (lb/yd $^{3}$ ) \\
\hline Cimento tipo II & 14 & 537 \\
Fosfogesso & 13 & 499 \\
Agregado grosso de & 73 & 2797 \\
pedra calcária & 8.5 & 326 \\
Água total & 5.6 & 215 \\
Água livre & & \\
\hline
\end{tabular}

A construção do trecho experimental do pavimento com concreto rolado e fosfogesso, consistiu das seguintes etapas: inicialmente espalha-se fosfogesso a uma profundidade de 5 polegadas misturando-o com o material de sub-base até uma profundidade de 8 polegadas. A compactação foi realizada com um rolo vibratório de aço. A mistura de concreto rolado foi preparada com fosfogesso e agregado de granulometria grossa. O material foi misturado e baseado no teor de umidade ótima. A mistura foi compactada com um rolo de pneu de borracha para prevenir fissuras. A operação foi completada usando um rolo vibratório de roda de aço. Durante a execução do pavimento tentou-se manter o controle de umidade através de um aferidor químico devido a hidratação do cimento.

Durante a operação de campo, foram coletadas amostras para análises em laboratório. A Tabela 2.17 mostra as propriedades mecânicas da mistura determinadas em laboratório. Foram obtidos bons resultados de resistência à compressão simples para as amostras de campo se comparadas com as amostras de laboratório. 
TABELA 2.17 - Propriedades mecânicas de laboratório e de campo das misturas de concreto compactado rolado Taha \& Seals (1991)

\begin{tabular}{|c|c|c|c|c|c|}
\hline \multirow{2}{*}{ Mistura } & \multirow{2}{*}{$\begin{array}{c}\text { Teor de } \\
\text { umidade } \\
\text { inicial (\%) }\end{array}$} & \multirow{2}{*}{$\begin{array}{c}\text { Massa } \\
\text { específica } \\
\text { seca inicial } \\
\text { (pcf) }\end{array}$} & \multicolumn{3}{|c|}{ Resistência à compressão } \\
\hline & & & $\begin{array}{c}28 \operatorname{dias} A^{* *} \\
(p s i)\end{array}$ & $B^{* *}(p s i)$ & $\begin{array}{c}90 \text { dias A } \\
\text { (psi) }\end{array}$ \\
\hline Campo & 8.5 & 131.1 & 2176 & 3174 & 2430 \\
\hline Laboratório & 8.0 & 132.7 & --- & 2767 & --- \\
\hline Ref/Lab* & 8.0 & 132.3 & --- & 3024 & --- \\
\hline
\end{tabular}

${ }^{*}$ ref/lab = nenhum fosfogesso

${ }^{* *} \mathrm{~A}=$ cilindro de dimensões $2.7 \times 5.4$ polegadas

*** $B=$ cilindro de dimensões $4.0 \times 4.5$ polegadas

Após três meses da execução do pavimento foi avaliado através de inspeções visuais que a superfície do pavimento não apresentava trincas.

Chang (1988) durante seus estudos com o fosfogesso avaliou também o comportamento de uma mistura de concreto rolado com este resíduo. Neste estudo ele utilizou $73 \%$ de agregados finos e grossos, $13 \%$ de cimento e $14 \%$ de fosfogesso. Os dados desta mistura foram comparados com uma mistura contendo $13 \%$ de cimento, mas sem fosfogesso (C13-0). Para a realização dos ensaios usou-se a energia de compactação equivalente ao Proctor modificado.

A mistura estudada por Chang (1988), C13-14, foi à mesma usada na construção do estacionamento na área do FIPR, onde conclui-se que esse estudo indica a viabilidade do uso do fosfogesso no concreto rolado para a construção de áreas de estacionamento.

As conclusões observadas por Chang (1988), para o uso do fosfogesso com concreto compactado rolado em pavimentação, foram as seguintes:

1. O fosfogesso fornece uma quantidade adicional de finos, levando a uma melhor compactação, trabalhabilidade e acabamento superficial sem reduzir a durabilidade a longo prazo;

2. Compensa os problemas relacionados à retração ao limitar o trincamento; 
3. Retarda o tempo de pega, assegurando a continuidade das juntas frias.

\subsection{EXPANSIBILIDADE DAS MISTURAS CONTENDO FOSFOGESSO}

Taha \& Seals (1991a) estudaram a expansão das misturas de fosfogesso e quatro tipos diferentes de cimento Portland. Para compor as misturas foi escolhido o teor de $10 \%$ para cada tipo de cimento. Depois de compactados, os corpos de prova tinham dimensões de $10,2 \mathrm{~cm}$ de diâmetro e $28,6 \mathrm{~cm}$ de altura. O relógio comparador, constituído de uma base circular com uma ou duas hastes verticais, na qual oferece suporte para uma plataforma, onde é fixado o extensômetro, foi usado para medir a variação do comprimento dos corpos de prova ao longo do eixo longitudinal. Os teores de $\mathrm{C}_{3} \mathrm{~A}$ presentes no cimento eram de $0 \%, 5 \%, 7 \%$ e $11 \%$, de acordo com o tipo de cimento.

Chang \& Mantell (1990) utilizaram cinco tipos de cimento Portland para analisar a expansão da mistura destes cimentos com o fosfogesso. As quantidades de $\mathrm{C}_{3} \mathrm{~A}$ variaram em intervalos de $4,3 \%$ e $14 \%$. O teor de cimento utilizado variou de $5 \%$ a $30 \%$, o de fosfogesso variou de 0 a $95 \%$ e o restante foi complementado com areia.

De acordo com os resultados obtidos por Chang \& Mantell (1990) chegaram à conclusão de que o uso de cimento com teores de $\mathrm{C}_{3} \mathrm{~A}$ menores que $7 \%$ por proporcionaram menores expansões.

Ouyang et al. (1988c) estudaram a expansão de misturas de fosfogesso e um único tipo de cimento com teor elevado de $C_{3} A$. Os resultados dos ensaios estão apresentados na Tabela 2.18. Observa-se que aumentando o teor de fosfogesso e diminuindo a quantidade de areia e mantendo-se constante o teor de cimento na mistura, ocorre um aumento na expansão. 0 aumento no teor de cimento nas misturas, para o mesmo tipo de cimento, também resulta no acréscimo da expansão. 
TABELA 2.18 - Propriedades mecânicas de laboratório e de campo das misturas de concreto compactado rolado Taha \& Seals (1991)

\begin{tabular}{cccccccc}
\hline $\begin{array}{c}\text { Teor } \\
\text { de } \\
\text { C }\end{array}$ & \multicolumn{3}{c}{ Composição (\%) } & \multicolumn{5}{c}{ Expansão (\%) } \\
\cline { 2 - 8 } & CP & FG & AREIA & 28 dias & 90 dias & 180 dias & 360 dias \\
\hline & 10 & 0 & 90 & 0,006 & 0,009 & 0,016 & 0,030 \\
& 10 & 8 & 82 & 0,019 & 0,036 & 0,049 & 0,067 \\
& 10 & 16 & 74 & 0.024 & 0,042 & 0,053 & 0,073 \\
$4,3 \%$ & 10 & 32 & 58 & 0,042 & 0,083 & 0,117 & 0,160 \\
\cline { 2 - 8 } & 20 & 0 & 80 & 0,006 & 0,008 & 0,016 & 0,030 \\
& 20 & 8 & 72 & 0,016 & 0,030 & 0,044 & 0,064 \\
& 20 & 13 & 64 & 0,020 & 0,036 & 0,049 & 0,077 \\
& 20 & 32 & 48 & 0,034 & 0,057 & 0,078 & 0,102 \\
\hline
\end{tabular}

\subsection{A CAL}

A decomposição térmica dos calcários/dolomitos/conchas calcárias resulta na formação de dois produtos - cal e dióxido de carbono. Essa reação, quimicamente bem estabelecida em relação às massas moleculares, é reversível para ambos os carbonatos de cálcio e magnésio.

Representação química da reação:

$$
\begin{aligned}
& \mathrm{CaCO}_{3}+\text { calor }-\mathrm{CaO}+\mathrm{CO}_{2} \\
& \mathrm{CaCO}_{3} \cdot \mathrm{M}_{\mathrm{g}} \mathrm{CO}_{3}+\text { calor }-\mathrm{CaO} \cdot \mathrm{MgO}+2 \mathrm{CO}_{2}
\end{aligned}
$$

\subsubsection{Origem Mineral}

Dentre as rochas minerais utilizadas pelo homem, destacam-se as rochas carbonatadas, que constituem $0,25 \%$ do volume da crosta. Encontramse distribuídas não só nas formações mais antigas, quanto nas mais recentes. Em geral, são sedimentos metamorfisados ou não, e mais raramente são rochas intrusivas relacionadas à atividade vulcânica alcalina.

\subsubsection{Rochas carbonatadas cálcio-magnesianas}

Essas rochas são constituídas em $50 \%$ ou mais pelos minerais: calcita (carbonato de cálcio - $\mathrm{CaCO}_{3}$ - romboédrico), aragonita (carbonato de cálcio $\mathrm{CaCO}_{3}$ - ortorômbico) e dolomita $\left(\mathrm{CaCO}_{3} \cdot \mathrm{MgCO}_{3}\right.$ - carbonato de cálcio e carbonato de magnésio - romboédrico). Entre os componentes minerais 
considerados como impurezas ou como secundários estão: quartzo, certos silicatos argilosos, óxidos metálicos de ferro e manganês, matéria orgânica, fosfatos, sulfetos, sulfatos e fluoretos. Os metais que acompanham mais freqüentemente a calcita e a dolomita são: titânio, cádmio, vanádio, cromo, cobalto, níquel, cobre, gálio, zircônio, molibdênio e estanho.

As aplicações dos calcários/dolomitos são direcionadas pela sua composição física e química. Destacam-se as utilizações como agregados, pedras ornamentais, pedra de construção, filer, meio filtrante, refratário, pigmentos de tintas, carga fundente de fornos da metalurgia dos não-ferrosos e do ferro, pó de mineração, filer de misturas asfálticas, corretivo de acidez do solo, nas indústrias de vidro, cerâmica, lã mineral, ração mineral, cimento Portland, cimento de alvenaria e cal.

Pela tradição, múltipla utilidade e benefícios sociais e econômicos, a cal é o principal produto derivado dos calcários/dolomitos/conchas calcárias. É obtida através de uma reação química simples - calcinação, mas requer conhecimento e habilidade para que o padrão de qualidade ideal seja atingido. Outra característica do produto são as amplas possibilidades da sua fabricação - em fornos rudimentares, de pequena produção, até fornos de alta tecnologia e produção volumosa - o que a tornou conhecida em todo o mundo.

\subsubsection{Cal virgem}

A cal virgem é o produto que resulta da dissociação térmica do calcário/dolomito/concha calcária. A reação que the dá origem é simples, mas requer recursos e conhecimentos complexos para sua perfeita realização. A cal é um nobre e importante produto à disposição dos homens, sendo plenamente adequada sua designação de "produto versátil e social".

Quando provém de rochas carbonatadas puras, a cal virgem é um produto inorgânico branco. Quando apresenta colorações creme, amarelada e levemente cinza, é sinal que contém impurezas. Seu odor é equivalente ao "terroso". Apresentam-se como cristais isolados ou conglomerados cristalinos, de dimensões e espaços intercristalinos variados, observáveis somente por microscopia. 
Os itens mais importantes na formação do custo do produto são: combustível, mão-de-obra e depreciação, seguidas pelos fatores relacionados a juros, refratários, energia elétrica, manutenção, controle de qualidade, seguros, impostos e administração.

A divergência sobre os custos industriais da cal é muito grande, principalmente pela diversidade de técnicas empregadas na fabricação do produto, ociosidade dos fornos (em função do mercado), nível de administração e outros fatores.

\subsubsection{Cal hidratada}

A cal hidratada resulta do prosseguimento do processo industrial que dá origem à cal virgem. A reação química que a produz, com a presença da água, é uma clássica "reação de fases sólido-líquida". Dependendo do volume de água utilizada para a reação, o produto final pode ser seco ou com aspectos de creme, lama, leite ou solução saturada.

A composição química da cal hidratada varia de acordo com as características da cal virgem que lhe dá origem, resultado das seguintes reações:

$$
\mathrm{CaO}+\mathrm{H}_{2} \mathrm{O}-\mathrm{Ca}(\mathrm{OH})_{2}+\text { calor (15.300 cal/formulagrama.); }
$$

Dolomítica normal:

$$
2 \mathrm{CaO} . \mathrm{MgO}+3 \mathrm{H}_{2} \mathrm{O}-2 \mathrm{Ca}(\mathrm{OH})_{2}+\mathrm{Mg}(\mathrm{OH})_{2}
$$

a hidratação de uma fórmula grama de MgO produz (8.800 a 10.000 cal/formulagrama.);

Dolomita sob pressão:

$$
\mathrm{CaO} \cdot \mathrm{MgO}+\mathrm{H}_{2} \mathrm{O}+\text { pressão }-\mathrm{Ca}(\mathrm{OH})_{2}+\mathrm{Mg}(\mathrm{OH})_{2}+\text { calor. }
$$

O volume de água utilizado para hidratar a cal virgem industrializada varia com as características físicas, químicas e mineralógicas da cal e também com o método e o hidratador empregados.

Cal hidratada é o nome genérico de todas as formas de hidratos. Mas a cal hidratada, propriamente dita se apresenta como pó seco, com 17\% a 19\% de água combinada, quando dolomítica normal e $24 \%$ a $27 \%$ de água 
combinada, quando cálcica ou hidratada sob pressão. As demais formas de hidratos têm nomes próprios.

A cal hidratada úmida é resultante de excesso de água: pasta de cal cal virgem hidratada com $30 \%$ a $45 \%$ de água livre; lama de cal - quando o volume de água livre varia de $55 \%$ a $73 \%$; de cal - quando o volume de água livre varia de $80 \%$ a $99 \%$; água de cal - quando o hidrato está em solução pura, sem qualquer sólido em suspensão, atingiu $\left(10^{\circ} \mathrm{C}-1,33 \mathrm{~g} / \mathrm{L}\right.$ para $\mathrm{Ca}(\mathrm{OH})_{2}$ e $0,01 \mathrm{~g} / \mathrm{L}$ para $\mathrm{Mg}(\mathrm{OH})_{2}$.

A cal hidratada sob pressão é o produto resultante do processo ao qual é submetida a cal virgem de natureza dolomítica ou magnesiana, para ter todos os seus óxidos transformados em hidratos.

Parte da cal virgem magnesiana ou dolomítica não é hidratada à pressão atmosférica, qualquer que seja o tempo de retenção no hidratador. Inicialmente há uma pequena percentagem de óxido de magnésio que se hidrata. Muitas vezes, essa percentagem pode ser aumentada com retenção no silo, por 10 a 24 horas e excesso de umidade.

\subsection{A CAL COMO ESTABILIZANTE}

Das reações que se processam com a cal e certos solos, resultam em alterações nas características do solo que permitem, então, a sua utilização como base de pavimentos rodoviários.

A estabilização de solos finos com cal é uma alternativa de custo relativamente baixo, se comparada às soluções tradicionais. Sua utilização, em rodovias, iniciou nos Estados Unidos, na década de 20. No Brasil, os primeiros relatos datam do final da década de 60. Guimarães (1971) relatou algumas experiências de pistas experimentais no Brasil, dentre as quais destacam-se: aeroporto de Congonhas (área de hangares da Varig), rodovia Curitiba-Porto Alegre (próximo ao Km 10, no Estado do Paraná), rodovia Brasília-Fortaleza (próximo a Sobradinho-DF), BR-377 - Ligação Cruz Alta-Carazinho (dois trechos experimentais).

Quando a cal é adicionada em alguns tipos de solos, principalmente siltosos e argilosos, a mistura final nem sempre desenvolve a resistência 
esperada, mesmo depois de longo período de "cura". Portanto, adota-se o artifício de juntar à cal com outro aditivo, que permite o surgimento de reações químicas ou físico-químicas aglomerantes na mistura, favorecendo a obtenção dos valores indicados pelo projeto.

Dentre as aplicações da cal com outros aditivos, o maior sucesso é obtido com o uso do material pozolânico denominado "fly ash" ou "cinzas volantes", resíduo industrial existente em abundância como refugo nas usinas térmicas a carvão. Esse material contém sílica ativa, elemento necessário para o aparecimento de reações entre a cal e o solo, na mistura compactada para o pavimento.

A mistura cal-pozolana tende a afetar as propriedades físicas do solo de maneira semelhante à cal pura, porém, mais acentuada. A extensão exata das alterações provocadas na resistência variam, mas, de modo geral, as propriedades mostram sempre a mesma tendência que resulta da aplicação da cal - redução das mudanças de volumes, abaixamento da plasticidade e aumento da resistência, o que melhora, sem dúvida, a resistência do pavimento às intempéries.

Muitos resíduos não podem ser empregados sozinhos por apresentarem baixas capacidades de suporte. Logo, misturas contendo fosfogesso e outros estabilizantes, como a cal, podem resultar em materiais adequados que apresentem algumas vantagens como: resistência à deformações; boa capacidade de retenção de água; boa capacidade contra o congelamento; trabalhável e de fácil construção; boa capacidade de suporte e baixo peso e boa capacidade de neutralização de materiais orgânicos (MOLINA, 2004).

Quando se adiciona cal a uma mistura, ocorrem várias reações, entre as quais podemos citar:

- A permuta iônica e floculação, onde se verifica uma diminuição da plasticidade devido à troca iônica pela quais os cátions $\mathrm{Ca}^{++}$, vão adsorver-se à superfície das partículas. Essa adsorção provoca a diminuição da sua eletronegatividade originando floculação e produzindo uma imediata melhora na plasticidade, trabalhabilidade e resistência sem cura; 
- A cimentação, reação lenta produzida em meios de $\mathrm{pH}$ elevado onde a solubilidade da sílica e alumina são aumentadas e combina-se com $\mathrm{Ca}^{++}$para formar silicato de cálcio, melhorando a resistência e sua estabilidade da mistura compactada;

- A carbonatação, combinação de óxido ou hidróxido de cálcio com anidrido carbônico presente nas minúsculas bolhas de ar, absorvidas e retiradas por ocasião da realização das misturas ou pela penetração do ar nos poros após a mistura de solo com a cal. A reação tende a refazer $\mathrm{o}$ carbonato original, visto que a decomposição desse composto pelo calor, é uma reação reversível. Desse fato resulta ação cimentante da cal, porque ela faz aparecer um novo corpo sólido que trava e firma as partículas do solo.

\subsubsection{Efeitos da cal sobre as misturas}

O processo de estabilização de solos com cal pode ser dividido em duas fases: uma fase rápida (minutos a dias) e uma fase lenta (semanas a anos). A fase rápida é caracterizada pelos fenômenos de troca catiônica, floculaçãoaglomeração, provocando melhoria imediata na plasticidade, na trabalhabilidade e na resistência (sem cura). A fase lenta é caracterizada pelas reações pozolânicas, que formam produtos cimentantes, proporcionando ganho de resistência e de durabilidade com o tempo de cura.

O critério de reatividade de Thompson qualifica como reativos solos que, quando estabilizados com cal, apresentam ganhos de resistência maiores que $345 \mathrm{kPa}$, após 28 dias de cura.

Já pelo critério utilizado pelo Departamento de Estradas do Texas e Louisina, quando o solo é estabilizado com a cal, apresenta uma resistência mínima de 677kPa para base e 338kPa para sub-base.

De modo geral, a cal sempre afeta de forma favorável algumas propriedades dos solos, o que se reflete em variações das características físicas. A adição da cal diminui o índice de plasticidade devido ao efeito da troca iônica. Quando se adiciona a cal aos solos, ocorre brusca redução das suas propriedades de expansão. Outra importante propriedade alterada pela 
adição da cal na mistura é o pH do solo, passando gradativamente de ácido para alcalino.

Com relação à granulometria, a principal conseqüência da adição de cal ao solo, é a aglomeração e floculação por troca iônica processada nas finíssimas partículas de argila, reativas, produzindo um solo mais grosseiro, mais permeável e mais friável. Em geral, a influência da cal na granulometria é tanto maior quanto mais fino e argiloso for o solo inicialmente, pois mais destacada é a alteração da textura com a agregação e floculação das partículas.

Diversos testes têm sido feitos para avaliar as resistências das misturas com cal: compressão não confinada, Índice de Suporte Califórnia, estabilômetro, extrusão, triaxial e mesmo agulha de penetração Proctor. Dentre esses, a compressão não confinada é mais popular, porém, todos mostram a mesma tendência, porém com grandezas não proporcionais.

Os principais fatores que afetam as resistências das misturas contendo cal são: o teor de cal, o tipo de solo ou de resíduo, a densidade, o tempo de cura e a qualidade da cal.

A compactação de uma mistura contendo cal produz, em geral, pela atuação da cal na textura do solo, uma menor resultante de massa especifica seca máxima e um maior teor de umidade ótimo que o correspondente à mistura original. Segundo Molina (2004) isto não acontece sempre porque são conhecidas misturas que não apresentam essas características. O aumento na umidade ótima é devido à reação pozolânica e a diminuição, ao intercâmbio catiônico. Portanto, o balanceamento entre os dois efeitos pode resultar em pouca ou nenhuma mudança da umidade ótima, e conseqüentemente, pouca ou nenhuma mudança da massa especifica seca máxima.

Pode-se notar que, com a adição da cal, ocorrem melhoras nas propriedades mecânicas. Ensaios de CBR, compressão simples e cone de penetração mostram melhoras imediatas de várias vezes a resistência original, (MOLINA, 2004).

A resistência das misturas contendo cal é diretamente proporcional ao tempo de cura, devido às reações químicas e físico-químicas que nelas 
ocorrem. Em geral, a resistência das misturas estabilizadas com a cal aumenta rapidamente no período inicial, tal como se deve prever pela ordem de importância do desenvolvimento das reações. À medida que o tempo de cura cresce, a velocidade do aumento da resistência torna-se cada vez menor. As reações pozolânicas sendo lentas, fazem com que as resistências das misturas, ainda que muito lentamente, aumentem mesmo após alguns anos de idade. No campo e no laboratório, a resistência alcançada é também função das condições de umidade e de temperatura. Esta última consiste com o tempo de cura em dias, pelo índice maturidade (graus farienheit multiplicado pelo número de dias).

\subsubsection{Materiais calcários estabilizados com a cal}

Estudos têm sido publicados destacando o bom comportamento de materiais calcários, quando pequenos teores de cal hidratada são incorporados à mistura, incrementando a resistência pela introdução de íons $\mathrm{Ca}^{++}$solúveis, o que causa cimentação dos carbonatos, (MOLINA, 2004).

Os ensaios realizados por Bhuiyan et al. (1995) mostram que as misturas estabilizadas com cal têm importantes ganhos de resistência frente às misturas não estabilizadas. Foi também observado que os ganhos de resistência eram muito mais significativos para os materiais que apresentavam elevadas concentrações de calcita $\left(\mathrm{CaCO}_{3}\right)$. 


\section{MATERIAIS E MÉTODOS}

\subsection{INTRODUÇÃO}

Este capítulo aborda a forma como foi conduzida a investigação experimental desenvolvida com o fim de permitir o estudo das propriedades mecânicas de misturas compactadas compostas de fosfogesso e cal.

\subsection{MATERIAIS}

\subsubsection{Fosfogesso}

O fosfogesso utilizado na pesquisa é do tipo di-hidratado, apresentando características semelhantes ao utilizado nas pesquisas já realizadas por Parente (2002) na Escola de Engenharia de São Carlos-USP.

\subsubsection{Coleta e preparação}

O fosfogesso foi coletado em seu estado natural, no depósito pertencente a indústria de fertilizantes FOSFÉRTIL, localizada no município de Uberaba (MG). O depósito é dividido em lotes identificados através da sua idade, onde o mais antigo data de 1986. A idade influencia no pH do fosfogesso, pois lotes mais antigos apresentam maior $\mathrm{pH}$, ou menor acidez, em relação aos lotes mais recentes. $\mathrm{O}$ material coletado corresponde ao resíduo gerado no ano de 2001

Após coleta, o resíduo foi transportado para o Laboratório de Estradas da Escola de Engenharia de São Carlos USP.

A preparação do fosfogesso consistiu em sua secagem ao ar livre até se atingir a umidade higroscópica. Em seguida, o material foi homogeneizado com operações de destorroamento, passagem na peneira $\mathrm{n}^{0} 4$, e posterior 
quarteamento. Logo após, foi embalado em sacos plásticos e armazenado para o uso experimental. $\mathrm{O}$ aspecto final do fosfogesso bruto, imediatamente antes de ser ensacado, pode ser visto na Figura 3.1.

Encerrada a fase de preparação, deu-se início aos ensaios de caracterização, que consistiram nas determinações da granulometria, da massa específica dos sólidos, dos limites de Atterberg e do $\mathrm{pH}$, este último com a finalidade de medir a acidez após a fase de preparação.

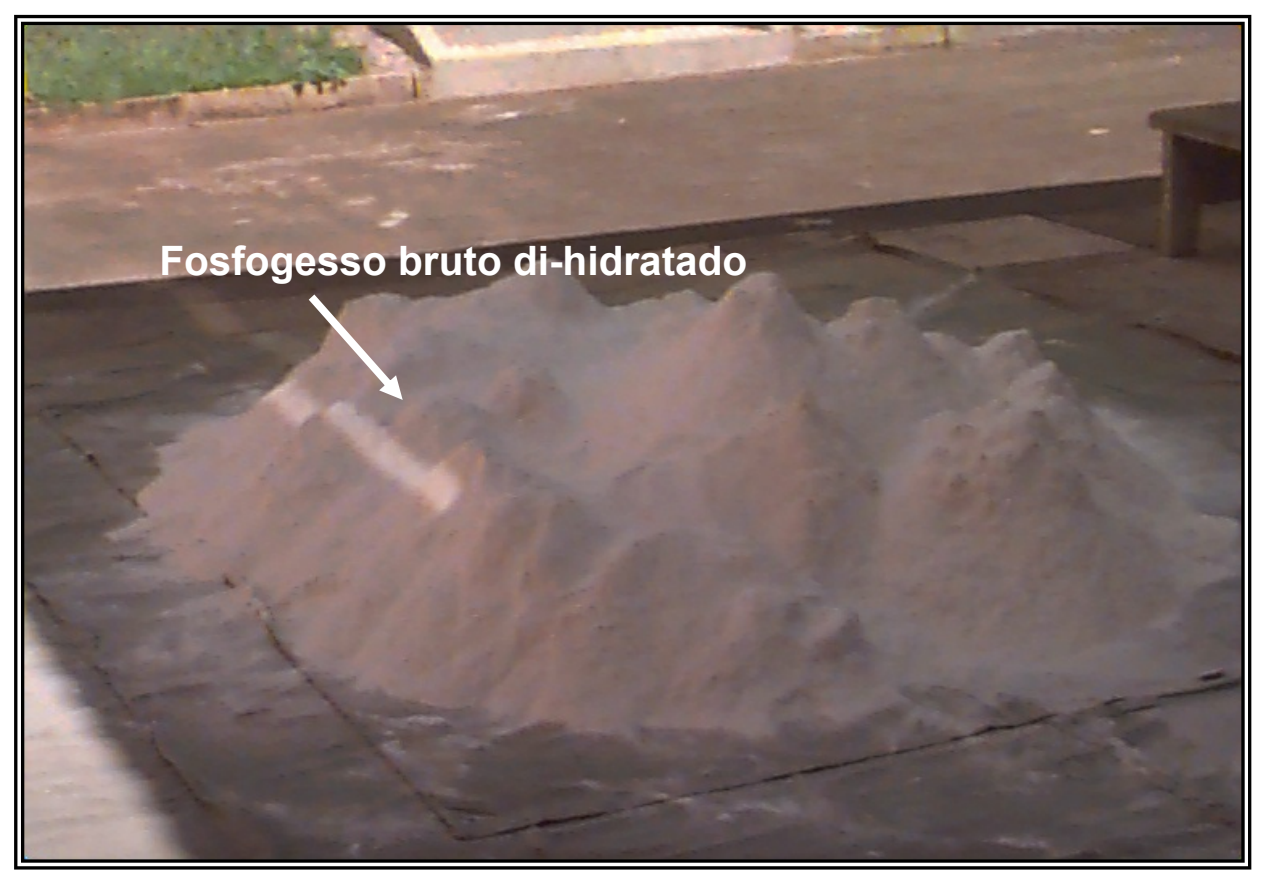

\section{FIGURA 3.1 - Fosfogesso bruto do tipo di-hidratado após secagem e homogeneização}

\subsubsection{Determinação do pH}

$\mathrm{Na}$ determinação do $\mathrm{pH}$ do fosfogesso, obteve-se o valor de 5,0. Esse resultado encontra-se no intervalo de variação de 2,5 a 6,0, determinado a partir de valores observados para diferentes tipos de fosfogesso pesquisados na Revisão Bibliográfica. TAKEDA (1998) mediu a acidez de duas amostras de fosfogesso di-hidratado da FOSFÉRTIL com diferentes idades; um deles apresentou $\mathrm{pH}$ de 2,4 e o outro $\mathrm{pH}$ de 5,0. A redução da acidez do fosfogesso com a idade é provocada pelo tempo maior de exposição do material às intempéries, 
que tem como conseqüência a lixiviação de parte dos elementos constituintes do fosfogesso responsáveis pela acidez.

\subsubsection{Granulometria}

A análise granulométrica foi realizada através do ensaio de granulometria conjunta, (peneiramento + sedimentação), de acordo com a norma DER/SP M 661 , que inclui o uso de uma série padronizada de 7 peneiras ( $n^{\text {os. }} 16,30,50,80$, 100 e 200). Desta forma, obteve-se como resultado a distribuição granulométrica apresentada na Figura 3.2. Analisando-se a referida curva, observa-se que o fosfogesso pode ser incluído na classe dos siltes, com mais de $75 \%$ de suas partículas passantes na peneira $\mathrm{n}^{\circ} 200$. O resultado mostrou-se coerente com os apresentados em bibliografia e nos trabalhos de Parente (2002).

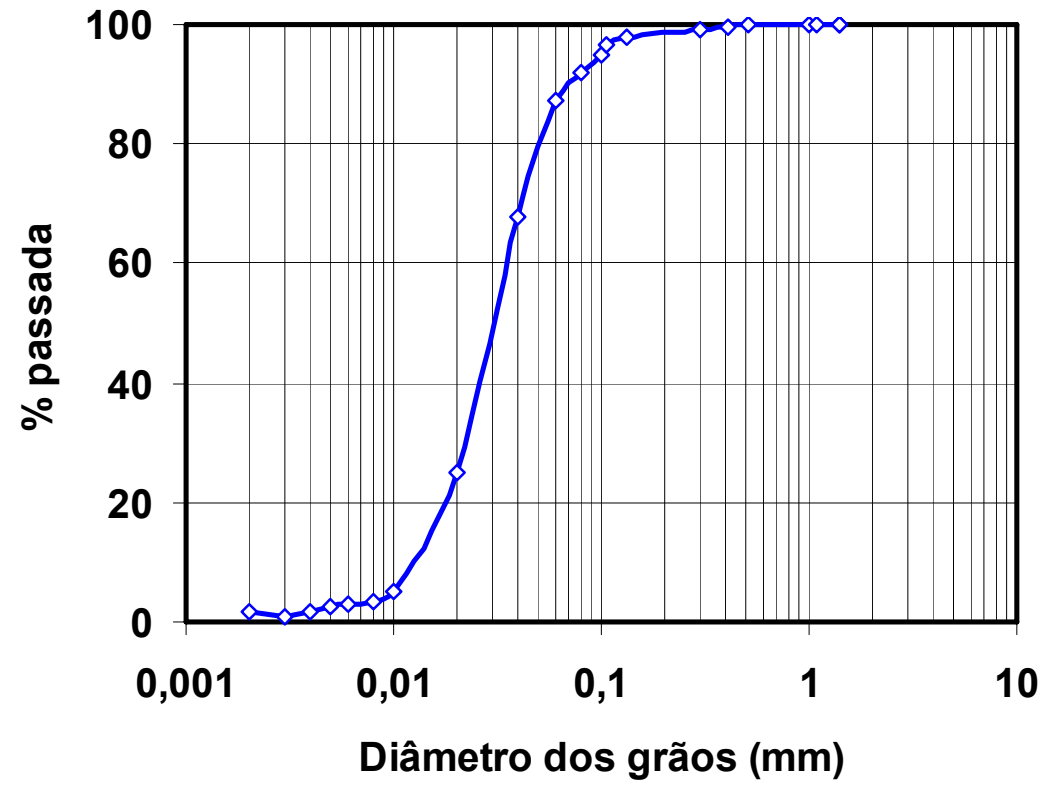

FIGURA 3.2 - Distribuição granulométrica do fosfogesso

\subsubsection{Massa específica dos sólidos}

A determinação da massa específica dos sólidos $\left(\rho_{s}\right)$ foi realizada segundo a norma DER/SP M 3-61 e foi obtido o valor de 2,526 $/ \mathrm{cm}^{3}$. Este resultado é um pouco superior aos valores de $2,320 \mathrm{~g} / \mathrm{cm}^{3}$ e $2,308 \mathrm{~g} / \mathrm{cm}^{3}$ obtidos por Takeda (1998) e Parente (2002), para duas amostras diferentes de fosfogesso di- 
hidratado. Essa variação pode ser atribuída ao fato do fosfogesso conter diversas impurezas e sua composição variar conforme a rocha fosfática utilizada na produção de ácido fosfórico.

\subsubsection{Limites de Atterberg}

O ensaio para determinação do limite de liquidez, segundo a norma DER/SP M 4-61, foi considerado irrealizável, pois a pasta de fosfogesso não apresentou a trabalhabilidade necessária para a sua execução. No ensaio de plasticidade não foi possível a moldagem dos bastonetes, conforme a norma DER/SP M 5-61, levando a classificar o material como não plástico (NP). Nos estudos anteriormente realizados por Ortiz (1997), Takeda (1998) e Parente (2002) também não se obteve êxito na determinação dos limites de Atterberg.

\subsubsection{A cal}

A cal utilizada para a realização dos ensaios é uma cal cálcica do tipo $\mathrm{CH}$-III hidratada, segundo a norma da ABNT NBR 7175, da marca Supercal. O material foi escolhido por ser comercializado na região de São Carlos/SP. As características dessa cal, segundo o fabricante, estão apresentadas na Tabela 3.1 .

TABELA 3.1 - Características da cal cálcica, Supercal CH-III

\begin{tabular}{ccc}
\hline $\begin{array}{c}\text { Caracteristicas da } \\
\text { matéria prima }\end{array}$ & Composição química & $\begin{array}{c}\text { Caracterização } \\
\text { granulométrica }\end{array}$ \\
\hline $\begin{array}{c}\text { Estrutura Microcristalina: } \\
\text { romboédrica }\end{array}$ & $\mathrm{Ca}(\mathrm{OH})_{2}: 92,5 \%-98.5 \%$ & $\mathrm{D}_{50}=19$ \\
$\begin{array}{c}\text { Origem: sedimentar } \\
\text { marinha }\end{array}$ & $\mathrm{MgO}: 3,5 \%$ máx & $\mathrm{D}_{90}=55$ \\
$\begin{array}{c}\text { Massa específica dos } \\
\text { grãos: } 2,7 \mathrm{~g} / \mathrm{cm}^{3}\end{array}$ & $\mathrm{SiO}_{2}: 0,3 \%$ máx & \\
Dureza Mohs de 3,0 & $\mathrm{R}_{2} \mathrm{O}_{3}: 1,5 \%$ máx & \\
\hline
\end{tabular}

Fonte: Ficha técnica do produto (CARBOMIL, 2003) 


\subsection{COMPOSIÇÃO DAS MISTURAS}

\subsubsection{Estudo preliminar}

Inicialmente, foram determinadas as resistências à compressão simples de corpos-de-prova compostos por $5 \%$ de cal e $95 \%$ de fosfogesso e $10 \%$ de cal e $90 \%$ de fosfogesso, compactadas na energia equivalente ao Proctor normal, ensaiados segundo a norma DER/SP M 13-71. Para os corpos-de-prova compactados na energia equivalente ao Proctor modificado, baseado na norma DER/SP M 13-72, foram determinadas as resistências à compressão simples dos corpos-de-prova compostos por: $3 \%$ de cal e $97 \%$ de fosfogesso, $5 \%$ de cal e $95 \%$ de fosfogesso, $7 \%$ de cal e $93 \%$ de fosfogesso e $10 \%$ de cal e $90 \%$ de fosfogesso. Nesta etapa, para ambas as energias de compactação, as resistências foram determinadas sem imersão previa em água. Para os corpos-de-prova compactados na energia equivalente ao Proctor normal, os valores de resistência à compressão simples situaram-se muito abaixo daqueles exigidos comumente para a construção de bases rodoviárias. Assim decidiu-se que o prosseguimento do estudo seria feito apenas com corpos-de-prova compactados na energia equivalente ao Proctor modificado.

\subsubsection{Estudo definitivo}

Nesta etapa, todos os corpos-de-prova foram compactados na energia equivalente ao Proctor modificado, sendo analisadas as seguintes misturas: $0 \%$ de cal e $100 \%$ de fosfogesso, $3 \%$ de cal e $97 \%$ de fosfogesso, $5 \%$ de cal e $95 \%$ de fosfogesso, $7 \%$ de cal e $93 \%$ de fosfogesso e $10 \%$ de cal e $90 \%$ de fosfogesso.

A Tabela 3.2 apresenta as composições escolhidas para a avaliação do comportamento mecânico das misturas.

TABELA 3.2 - Misturas ensaiadas com os respectivos teores de cal

\begin{tabular}{ccc}
\hline Misturas & Fosfogesso (\%) & Cal (\%) \\
\hline Mistura 1 & 97 & 3 \\
Mistura 2 & 95 & 5 \\
Mistura 3 & 93 & 7 \\
Mistura 4 & 90 & 10 \\
\hline
\end{tabular}




\subsection{ENSAIOS DE COMPACTAÇÃO DAS MISTURAS}

Os ensaios de compactação foram realizados com o objetivo de se obter a massa específica seca máxima e a umidade ótima correspondentes a cada mistura.

Antes de se realizar a compactação, a mistura de fosfogesso e cal recebiam a adição de água necessária para variar a umidade ótima conforme desejado, repetindo-se então o processo de homogeneização. Em seguida, passava-se o material na peneira $\mathrm{n}^{\circ} 4$ (abertura da malha de $4,76 \mathrm{~mm}$ ), e novamente realizavase a sua homogeneização.

A determinação de umidade era sempre realizada em estufa com ventilação forçada e uma temperatura máxima de $50^{\circ} \mathrm{C}$. A escolha da temperatura de $50^{\circ} \mathrm{C}$ deve-se ao fato do fosfogesso ser do tipo di-hidratado e sabe-se que temperaturas acima desse valor podem provocar a desidratação de sua água molecular.

A cal não passou por nenhum processo de preparação específico e foi usado na forma como é comercializada. Porém, teve-se o cuidado de manter as embalagens sempre fechadas quando não em uso e de observar o prazo de validade.

Depois de preparadas, as misturas eram acondicionadas em sacos plásticos com o propósito de conservar sua umidade antes de serem compactadas.

Durante a compactação da mistura, não houve reuso do material, repetindose o processo de mistura para cada umidade de compactação.

\subsection{PROPRIEDADES MECÂNICAS DAS MISTURAS}

A determinação das propriedades mecânicas das misturas baseou-se nos resultados dos ensaios de compressão simples, compressão diametral e CBR. 


\subsubsection{Ensaio de compressão simples}

Para todas as misturas citadas no Item 3.3.2 foram realizados ensaios de compressão simples para os corpos-de-prova moldados na umidade ótima e massa específica seca máxima. Os ensaios foram executados no Departamento de Estradas da Escola de Engenharia de São Carlos, seguindo os procedimentos da norma ABNT (1992) NBR 12770.

Os corpos-de-prova foram submetidos a duas condições de ensaio: sem imersão e após imersão prévia em água por um período de 4 horas, simulando uma situação crítica para pavimentos. A imersão prévia em água durante 4 horas, como preparação para o ensaio de compressão simples teve o objetivo de possibilitar a avaliação do efeito da água na resistência das misturas.

No estudo definitivo, foram confeccionados 4 corpos-de-prova para cada uma das condições de ensaio (sem imersão e após imersão prévia em água por 4 horas), e para cada um dos tempos de cura (imediatamente após compactação, 3 dias, 7 dias e 28 dias), resultando 32 corpos de prova para cada composição analisada ( $0 \%, 3 \%, 5 \%, 7 \%$ e $10 \%)$. Assim, foram ensaiados 160 corpos-de-prova.

Para a realização dos ensaios de compressão simples, as misturas foram compactadas estaticamente em três camadas. Para tanto, utilizou-se um molde cilíndrico metálico, resultando corpos-de-prova com dimensões de aproximadamente $5 \mathrm{~cm}$ de diâmetro e $10 \mathrm{~cm}$ de altura.

O molde utilizado na compactação constitui-se de um conjunto de peças metálicas acopláveis formado de um corpo cilíndrico principal, dois anéis complementares e dois êmbolos espaçadores, como apresentado na Figura 3.3. 


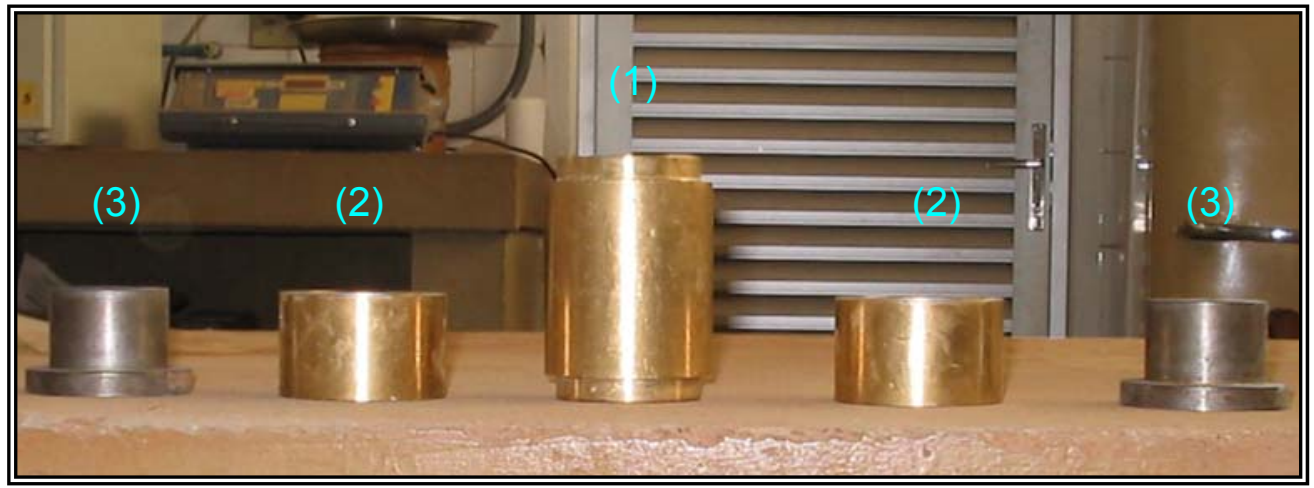

FIGURA 3.3 - Equipamento para moldagem dos corpos de prova de compressão simples (1) cilindro principal, (2) anéis complementares, (3) êmbolos espaçadores

Antes de se compactar as misturas, o cilindro era lubrificado com óleo automotivo para reduzir o atrito dos grãos da mistura com a parede interna do cilindro.

Depois de decorrido o tempo de cura, os corpos-de-prova foram submetidos ao ensaio de compressão simples, conforme ilustra a Figura 3.4, tendo sido utilizada uma velocidade de carga de $1 \mathrm{~mm} / \mathrm{min}$ até o rompimento do corpo-deprova.

A força aplicada nos corpos-de-prova e sua deformação durante o ensaio são monitoradas por painéis eletrônicos e registradas por um programa de aquisição de dados que fornece um relatório de cada ensaio executado. 


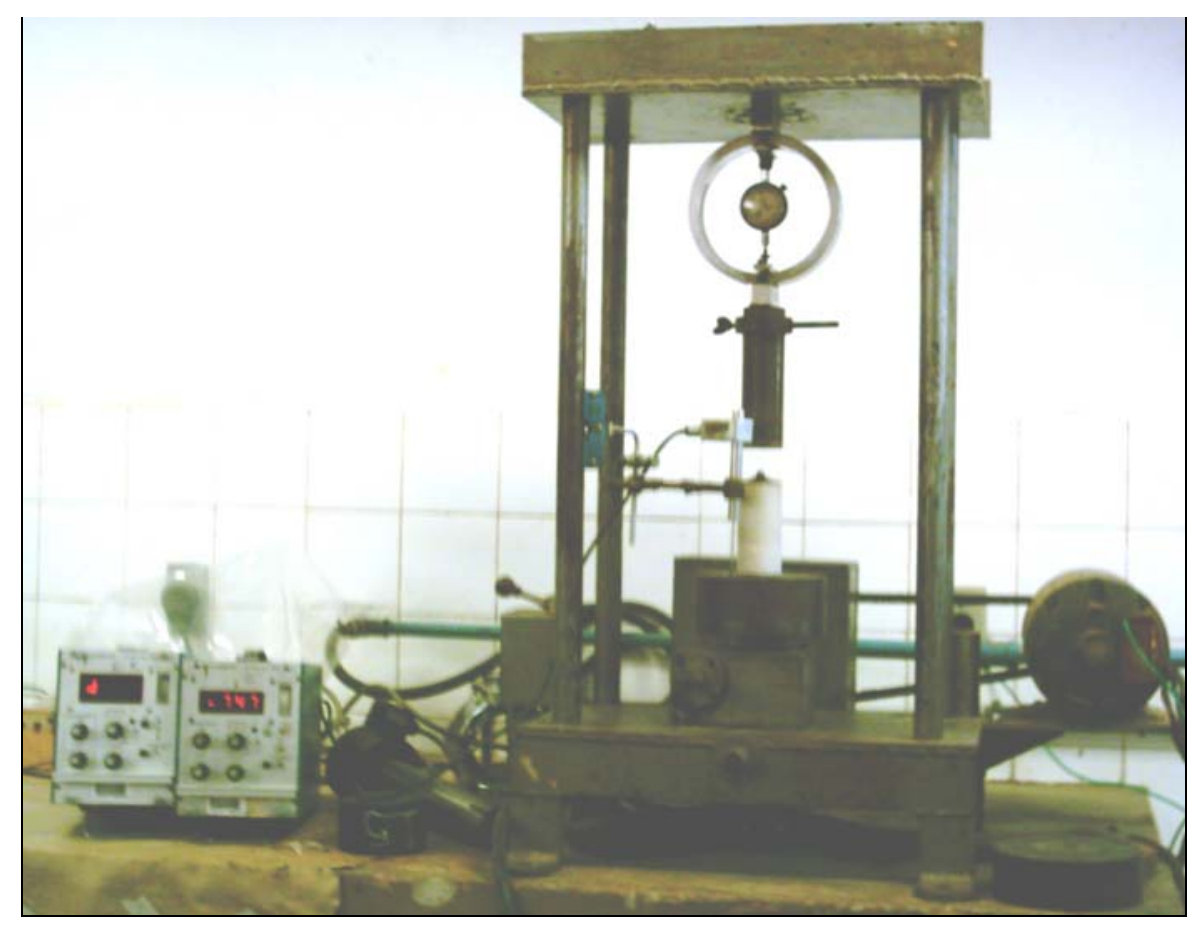

FIGURA 3.4 - Ruptura dos corpos-de-prova de compressão simples

\subsubsection{Análise dos resultados}

Os ensaios de compressão simples foram direcionados para a determinação da resistência à compressão simples e deformabilidade das misturas, e para a análise da influência da imersão em água, do tempo de cura e do teor de cal nestes parâmetros.

Adotou-se o módulo tangente inicial $\left(E_{0}\right)$ para a representação da deformabilidade. Para a determinação do $\mathrm{E}_{0}$, utilizou-se o procedimento proposto por DUNCAN \& CHANG (1970) que supõe a curva tensão deformação uma hipérbole, cuja expressão é representada na Equação 3.1.

$$
\frac{\varepsilon_{a}}{\sigma_{a}}=a+b . \varepsilon_{a}
$$

onde: 
$\varepsilon_{\mathrm{a}}-$ deformação axial $(\mathrm{mm} / \mathrm{mm})$

$\sigma_{\mathrm{a}}-$ tensão axial $(\mathrm{kPa})$

$a$ e b-coeficientes de regressão.

Assim, o módulo tangente inicial é calculado pela expressão:

$$
E_{0}=\frac{1}{a}
$$

A Figura 3.5 ilustra graficamente a estimativa de $E_{0}$ a partir do coeficiente "a".

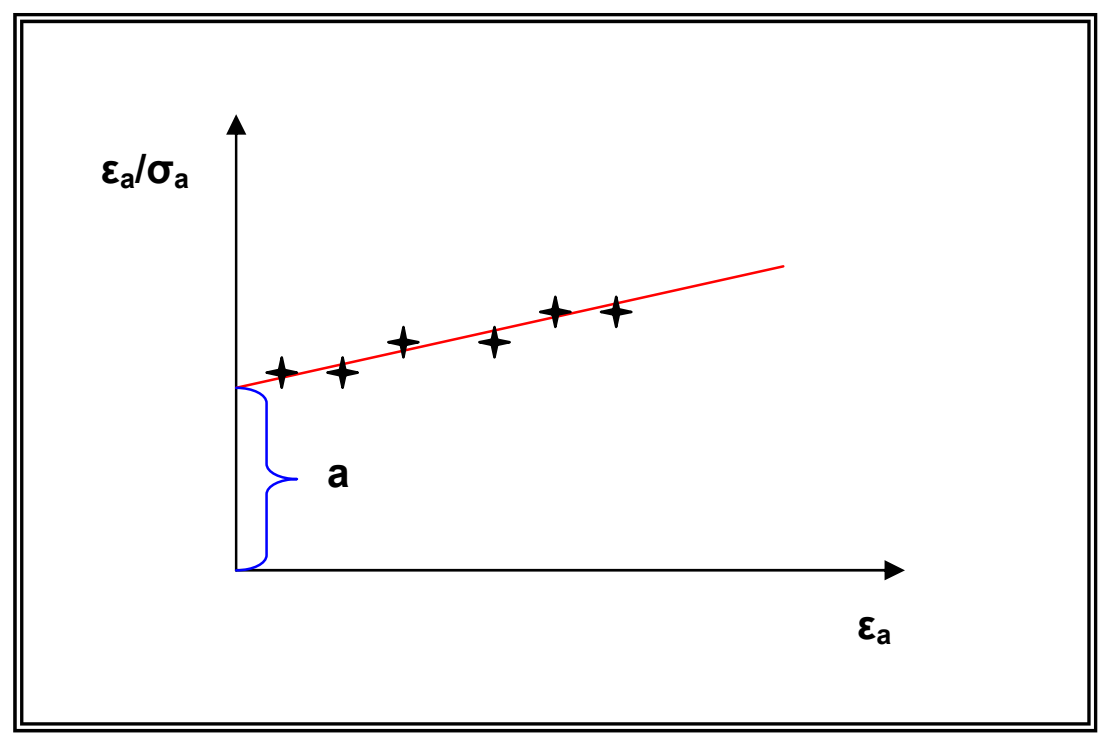

FIGURA 3.5 - Exemplo da estimativa de $E_{0}$ a partir da determinação do coeficiente "a", segundo o modelo hiperbólico proposto por DUNCAN \& CHANG (1970)

Ressalta-se que devem ser descartados os pontos iniciais da curva tensão x deformação, devido à imprecisão existente na determinação de deslocamentos muito pequenos, e os pontos posteriores à ruptura do corpo-de-prova ensaiado.

\subsubsection{Ensaio de compressão diametral.}

Para todas as misturas citadas no Item 3.3.2 foram realizados ensaios de compressão diametral para os corpos de prova moldados na umidade ótima e 
massa específica seca máxima. Os ensaios foram executados no Departamento de Estradas da Escola de Engenharia de São Carlos, seguindo os procedimentos da norma ABNT (1990) M1. Utilizou-se a mesma prensa na qual foram ensaiados os corpos-de-prova para compressão simples.

Os corpos-de-prova foram submetidos a duas condições de ensaio: sem imersão e após imersão prévia em água por um período de 4 horas simulando uma situação crítica para pavimentos. A imersão prévia em água durante 4 horas, como preparação para o ensaio de compressão simples teve o objetivo de possibilitar a avaliação do efeito da água na resistência das misturas.

No estudo definitivo, foram confeccionados 4 corpos-de-prova para cada uma das condições de ensaio (sem imersão e após imersão prévia em água por 4 horas), e para cada um dos tempos de cura (imediatamente após compactação, 3 dias, 7 dias e 28 dias), resultando 32 corpos-de-prova para cada composição analisada ( $0 \%, 3 \%, 5 \%, 7 \%$ e 10\%). Assim, foram ensaiados 160 corpos-de-prova.

Para a realização dos ensaios de compressão diametral, as misturas foram compactadas estaticamente em 1 camada, resultando corpos-de-prova com dimensões de aproximadamente $5 \mathrm{~cm}$ de diâmetro e $5 \mathrm{~cm}$ de altura.

O molde utilizado na compactação é um conjunto de peças metálicas constituído de corpo cilíndrico e dois êmbolos espaçadores.

Antes de se compactar as misturas, o cilindro era lubrificado com óleo automotivo para reduzir o atrito dos grãos da mistura com a parede interna do cilindro.

Depois de decorrido o tempo de cura, os corpos de prova foram submetidos ao ensaio de compressão diametral conforme ilustra a Figura 3.6, tendo sido utilizada uma velocidade de carga de $1,27 \mathrm{~mm} / \mathrm{min}$ até o rompimento do corpo de prova. 


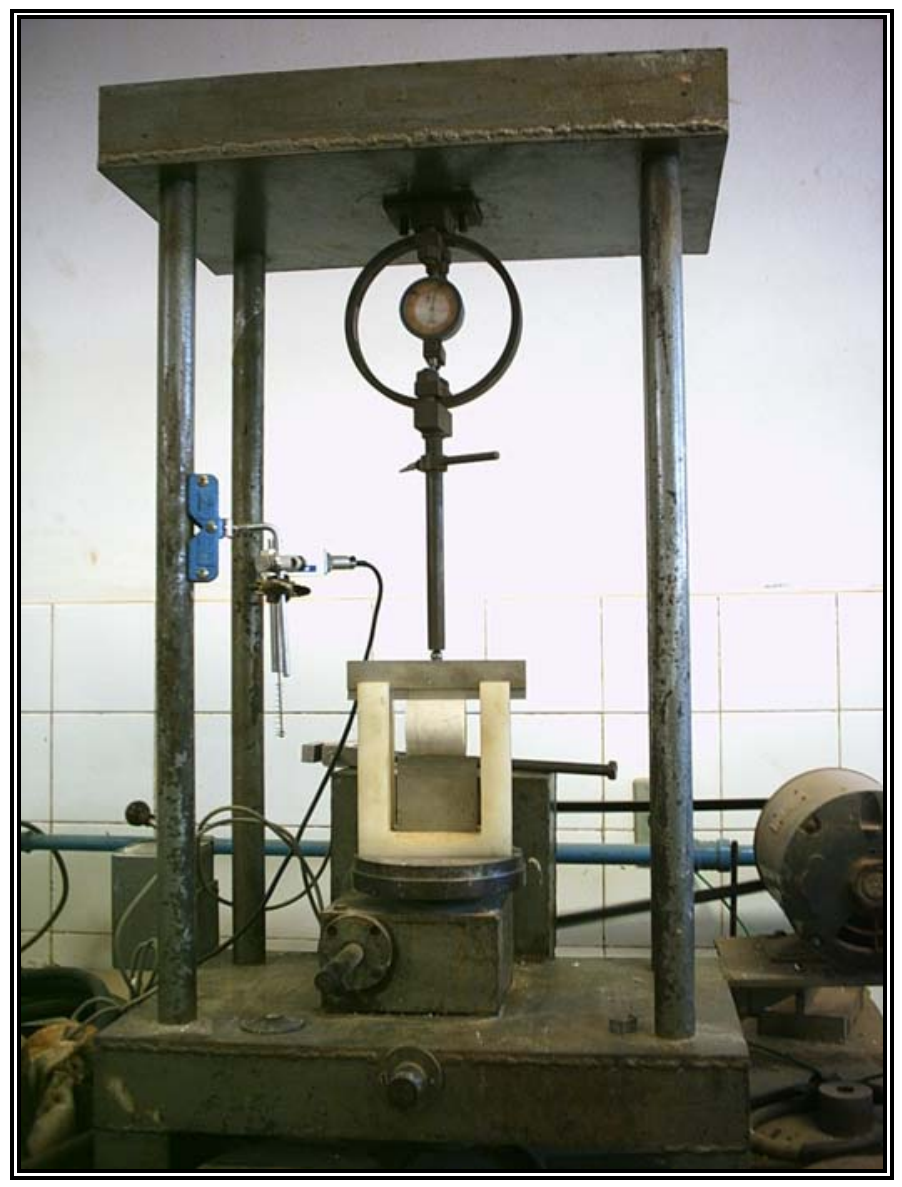

FIGURA 3.6 - Realização do ensaio de compressão diametral.

A Figura 3.7 ilustra o equipamento utilizado para ensaiar os corpos-deprova de resistência à tração por compressão diametral. 


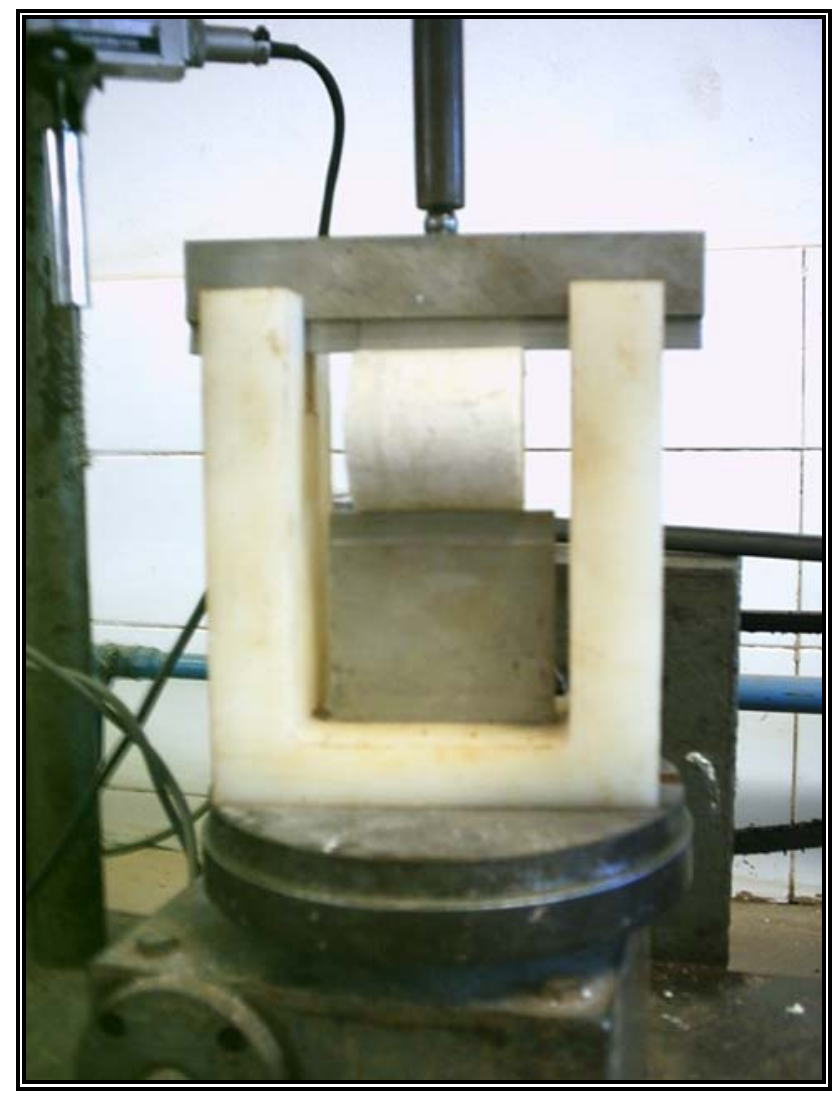

FIGURA 3.7 - Equipamento utilizado para a realização do ensaio de compressão diametral

\subsubsection{Análise dos resultados}

Os ensaios de compressão diametral foram direcionados para determinação da resistência à tração indireta das misturas de fosfogesso e cal.

A expressão para calcular a tração no centro da amostra é o seguinte:

$$
\sigma_{t}=\frac{2 F}{\pi D H}
$$

onde:

$\sigma_{\mathrm{t}}-$ resistência à tração, $\mathrm{kgf} / \mathrm{cm}^{2}$;

F - carga de ruptura, kgf;

D - diâmetro do corpo-de-prova, cm; 
$\mathrm{H}$-. altura do corpo-de-prova, $\mathrm{cm}$.

\subsection{3 Índice de Suporte Califórnia}

\subsubsection{Condição do ensaio}

Para todas as misturas citadas no Item 3.3.2 foram realizados ensaios de CBR para os corpos de prova moldados na umidade ótima e massa específica seca máxima. Os ensaios foram executados no Departamento de Estradas da Escola de Engenharia de São Carlos, seguindo os procedimentos da norma DER/SP - M53-71. Utilizou-se a mesma prensa na qual foram ensaiados os corpos-de-prova para compressão simples.

Antes de serem submetidos à penetração, os corpos-de-prova foram armazenados em câmera úmida durante 7 dias e posteriormente, colocados no tanque de imersão durante 4 dias. Durante este período, que totalizou 11 dias, a cura deu-se com os anéis de sobrecarga já instalados. A expansão foi medida somente no período em que os corpos de prova encontravam-se imersos na água, com extensômetro de $0,01 \mathrm{~mm}$ de precisão.

Foi confeccionado e ensaiado 1 corpo-de-prova para cada composição da mistura ( $0 \%, 3 \%, 5 \%, 7 \%$ e $10 \%$ de cal), totalizando 5 corpos-de-prova.

Após decorrer o tempo de cura, os corpos-de-prova foram submetidos ao ensaio de penetração conforme ilustra a Figura $\mathbf{3 . 8}$, tendo sido utilizada uma velocidade de carga de $1,24 \mathrm{~mm} / \mathrm{min}$. 


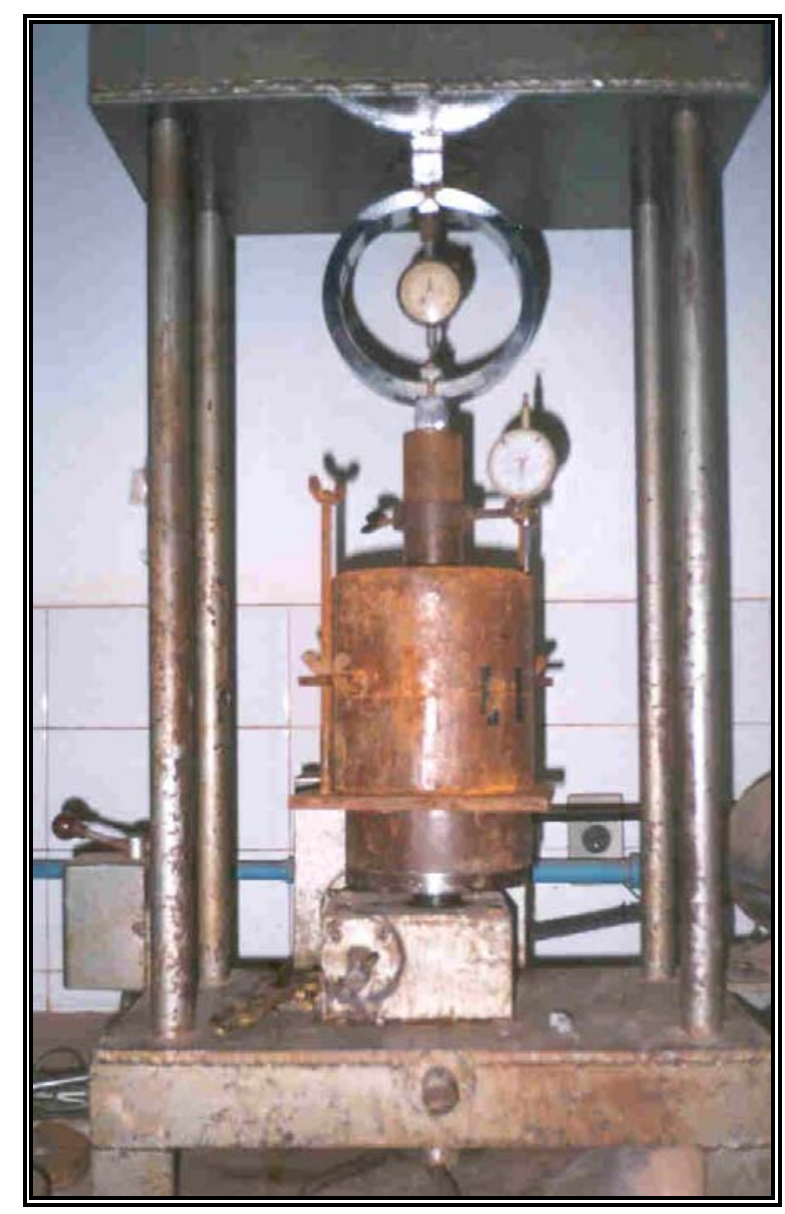

FIGURA 3.8 - Realização do ensaio do Índice de Suporte Califórnia.

\subsubsection{Análise dos resultados}

O ensaio de Índice de suporte Califórnia ofereceu subsídios para determinarem-se os valores de CBR e expansão das misturas.

\subsection{LIXIVIAÇÃO E SOLUBILIZAÇÃO}

Os ensaios de lixiviação e solubilização foram realizados no Laboratório de Saneamento da Escola de Engenharia de São Carlos. Estes ensaios basearam-se nas normas NBR 10.005/1987 (LIXIVIAÇÃO DE RESÍDUOS SÓLIDOSPROCEDIMENTOS) e NBR 10.006/1987 (SOLUBILIZAÇÃO DE RESÍDUOS SÓLIDOS-PROCEDIMENTOS).

Os ensaios foram realizados para todas as misturas propostas nesta pesquisa, ou seja, $0 \%, 3 \%, 5 \%, 7 \%$ e $10 \%$ de cal. Todas as amostras foram 
analisadas no estado solto, simulando situação de armazenagem do material em campo, bem como no estado compactado. Os corpos-de-prova foram compactados na umidade ótima e na energia equivalente ao Proctor modificado.

As amostras foram tratadas de acordo com as metodologias estabelecidas pela norma ABNT, para os testes de lixiviação (NBR 10.005) e solubilização (NBR 10.006) de resíduos sólidos (ABNT, 1987).

Para o ensaio de lixiviação, $100 \mathrm{~g}$ da massa úmida da mistura, bem como do fosfogesso puro, foram misturados a $1.600 \mathrm{~mL}$ de água deionizada. Após início de agitação da mistura, $\mathrm{o} \mathrm{pH}$ foi medido nos períodos de 15 minutos iniciais, 30 minutos após decorrido os 15 minutos e 60 minutos após os 30 minutos. Os valores de $\mathrm{pH}$ acima de 5 foram corrigidos mediante adição de ácido acético $0,5 \mathrm{~N}$, não ultrapassando a quantidade máxima de $400 \mathrm{~mL}$. A Figura 3.9 ilustra o procedimento de agitação da mistura.

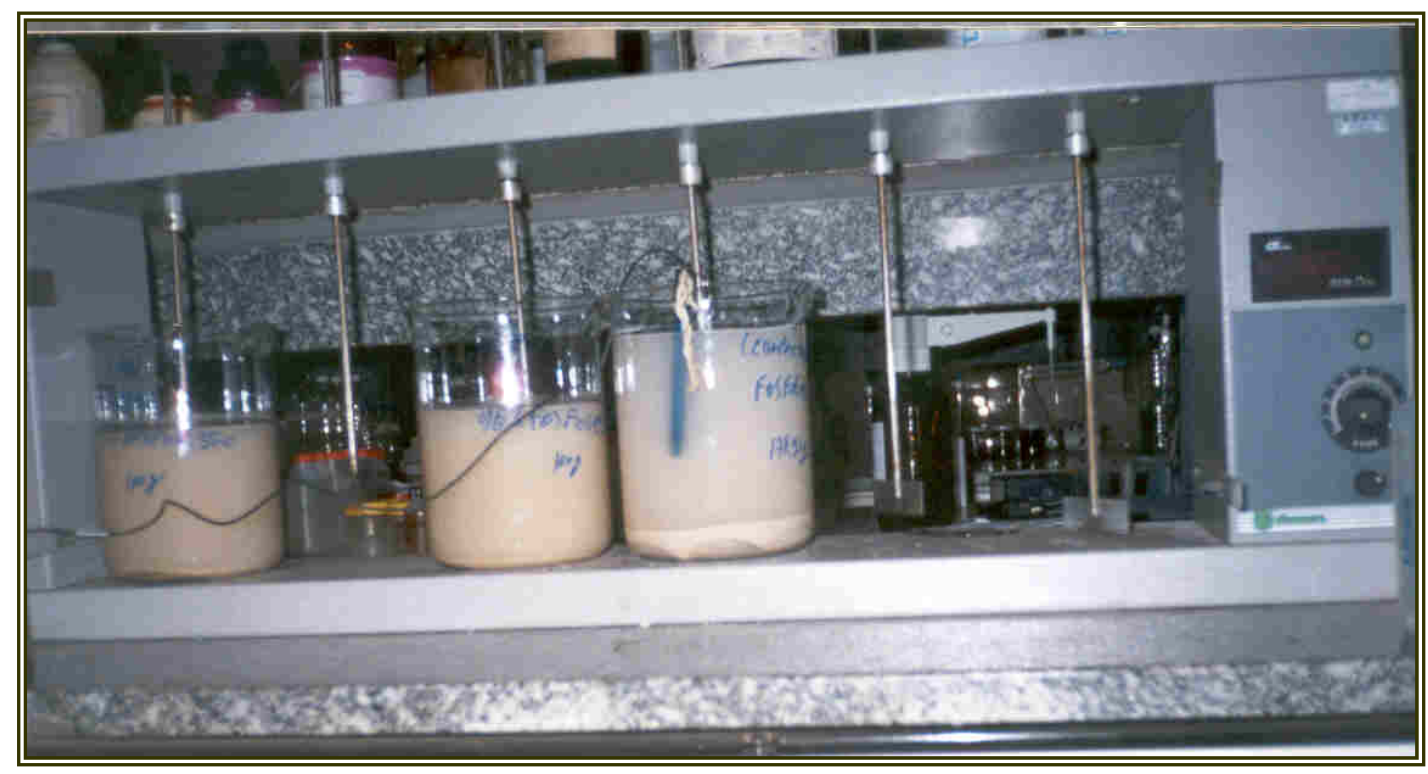

FIGURA 3.9 - Procedimento de agitação da mistura fosfogesso e cal e do fosfogesso puro, para o ensaio de lixiviação e solubilização.

Após agitação da mistura por um período de 24 horas, foi adicionado $400 \mathrm{~mL}$ de água deionizada, porém, se a mistura obtiver $\mathrm{pH}$ acima de 5 , diminui a quantidade de ácido acético adicionado, dos $400 \mathrm{~mL}$ de água deionizada. 
Posteriormente a amostra foi filtrada em filtro de papel, conforme ilustra a Figura 3.10, e após esta etapa, a mesma foi filtrada em membrana de fibra de vidro de $0,45 \mu \mathrm{m}$ de porosidade conforme ilustra a Figura 3.11. Esse procedimento simula condições ácidas que favorecem a lixiviação de alguns contaminantes e que podem ocorrer devido à decomposição da matéria orgânica presente nos resíduos urbanos, ao ser misturada com o resíduo industrial em uma área de disposição (ABNT, 1987b).

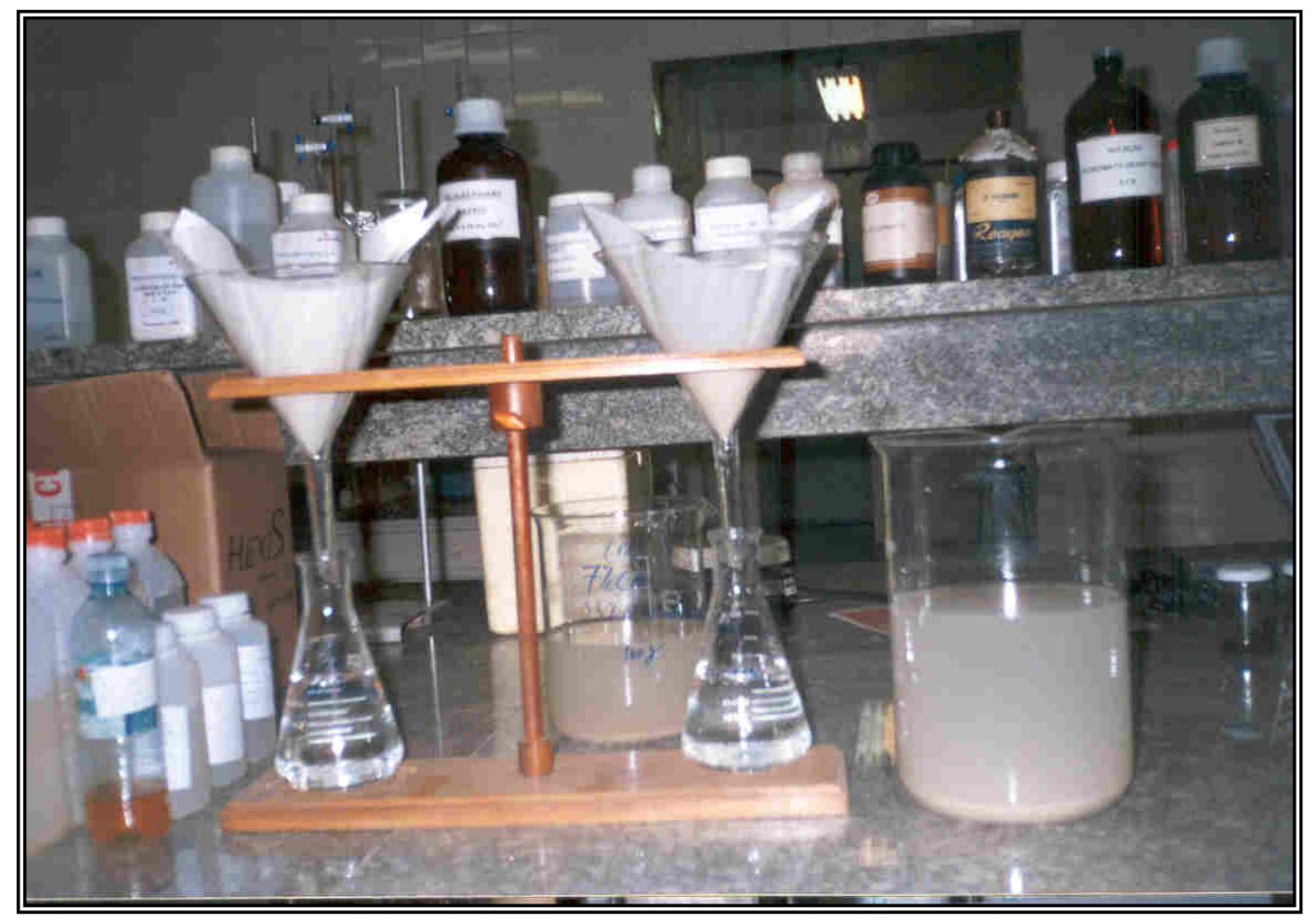

FIGURA 3.10 - Filtragem da amostra em papel de filtro após agitação durante o ensaio de lixiviação ou solubilização. 


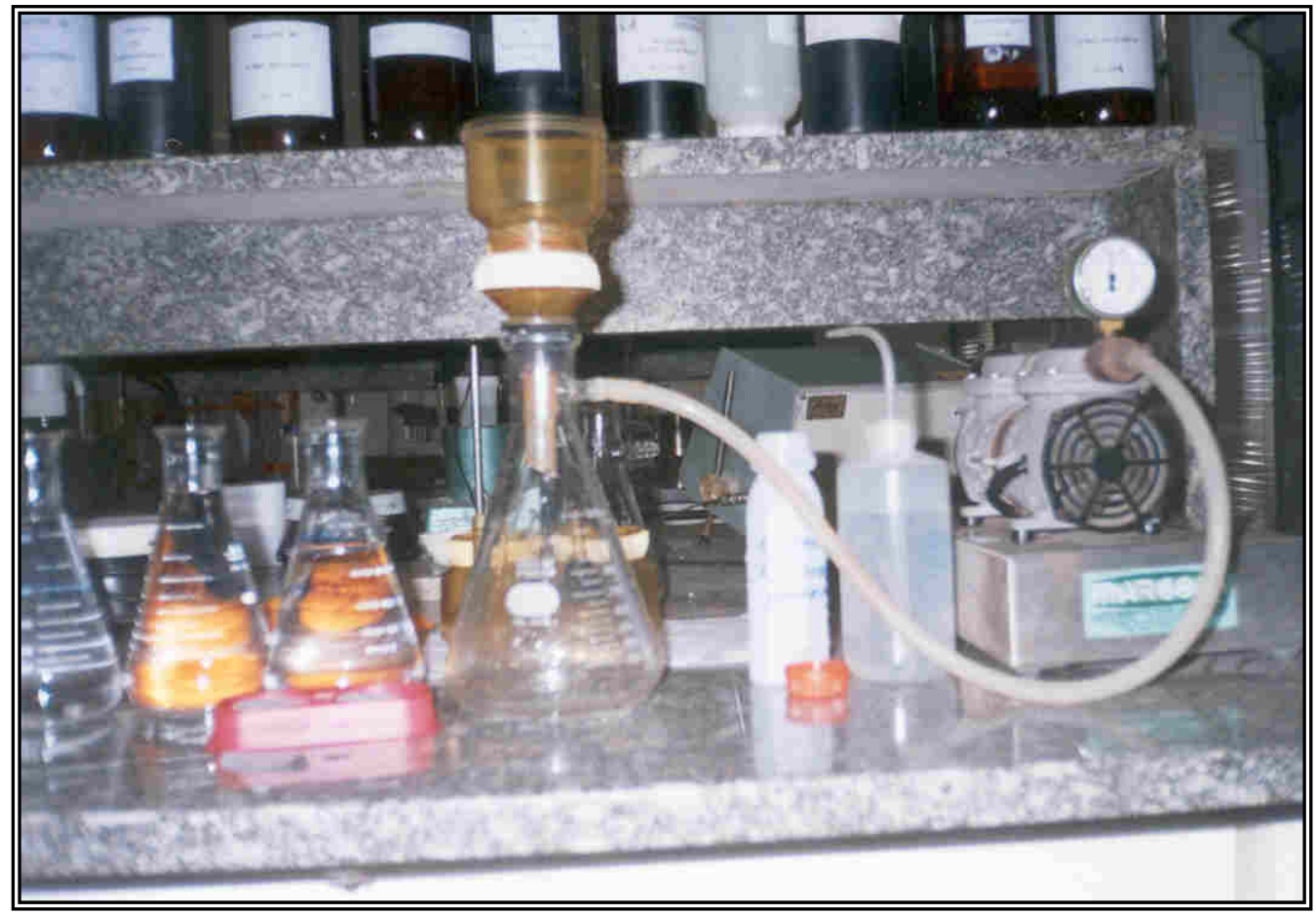

FIGURA 3.11 - Filtragem a vácuo das amostras através de membrana de fibra de vidro, para análise de metais.

Para o ensaio de lixiviação dos corpos de prova compactados, foi seguido o mesmo procedimento descrito acima, porém a quantidade de água deionizada e de ácido acético foi proporcional ao peso dos corpos de prova.

O processo de solubilização constituiu na mistura de $250 \mathrm{~g}$ da massa seca do resíduo, bem como da mistura, a $1.000 \mathrm{~mL}$ de água deionizada. Essa mistura foi agitada por 5 minutos, no mesmo aparelho utilizado para o ensaio de lixiviação. A amostra foi agitada a baixa velocidade, ficando em repouso, tampada, por sete dias conforme ilustra a Figura 3.12. Após esse período a amostra foi filtrada primeiramente em filtro de papel e posteriormente em membrana de fibra de vidro de $0,45 \mu \mathrm{m}$ de porosidade, originando o extrato solubilizado. Este procedimento é o mesmo utilizado para a filtragem das amostras lixiviadas. Esse procedimento tem por finalidade demonstrar que, uma vez em contato com a água, o resíduo não modificaria a qualidade dos padrões de potabilidade da água (ABNT, 1987d). 
Os valores de $\mathrm{pH}$ foram determinados nas amostras brutas do resíduo e da mistura de acordo com o método EPA 9045c, no qual $20 \mathrm{~g}$ da amostra bruta foram misturados a $20 \mathrm{~mL}$ de água deionizada. A mistura foi agitada por 5 minutos e, após repouso de 15 minutos, o pH do sobrenadante foi medido (EPA, 1996).

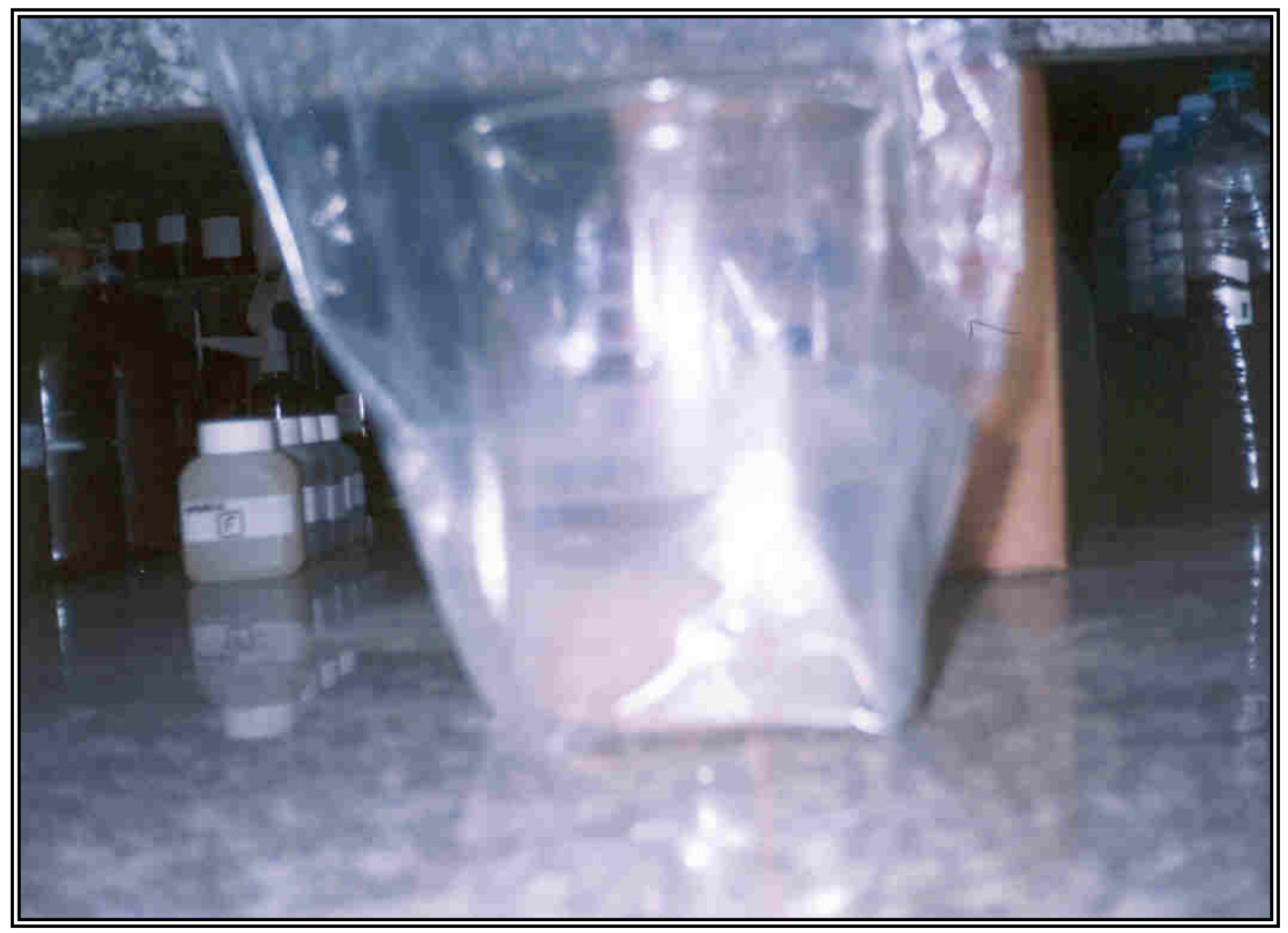

FIGURA 3.12 - Ensaio de solubilização, amostra lacrada por um período de 7 dias.

O líquido coletado do extrato lixiviado e solubilizado foram encaminhados para o Instituto de Química de São Carlos - USP, para a realização das análises químicas neste líquido. Estas análises têm como finalidade, obter as concentrações de metais pesados no fosfogesso e nas respectivas misturas analisadas.

As metodologias utilizadas na determinação dos parâmetros químicos nos extratos lixiviados e solubilizados requeridos pela NBR 10.004 foram baseadas no Standard Methods for Examination of Water and Wasterwater (APHA, 1995). 
Foram analisados os seguintes parâmetros nos extratos lixiviados e solubilizados:As, $\mathrm{Ba}, \mathrm{Cd}, \mathrm{Cr}$ total, $\mathrm{Pb}, \mathrm{Ag}$, Se. As avaliações foram realizadas em atenção ao Anexo G - Listagem n 7 da NBR 10.004 (ABNT, 1987c).

O mesmo procedimento foi utilizado para as amostras solubilizadas, nos quais foram analisados os seguintes parâmetros: $\mathrm{As}, \mathrm{Ba}, \mathrm{Cd}, \mathrm{Cr}$ total, $\mathrm{Pb}, \mathrm{Ag}$, $\mathrm{Se}$, nitrato e dureza, Fé, $\mathrm{Mn}, \mathrm{Na}$, constantes do Anexo $\mathrm{H}-$ Listagem $\mathrm{n}^{\circ} 8$ da NBR 10.004 (ABNT, 1987c).

O tratamento preliminar das amostras destinadas à determinação de metais nos extratos lixiviados e solubilizados constou de um ataque com $\mathrm{HNO}_{3}(50 \mathrm{~mL}$ do extrato+ $5 \mathrm{~mL}$ de ácido), de acordo como método EPA 3015 (EPA, 1996), utilizando-se a técnica de digestão por microondas em sistema fechado (CEM 2000).

A determinação dos metais nos extratos digeridos foi realizada por espectrometria e absorção atômica (Varian) ou espectrometria de emissão atômica com fonte de plasma induzida (Perkin Elmer ICP-AES Optima 3.000).

\subsubsection{Análise dos resultados}

Os resultados dos ensaios de lixiviação, solubilização e absorção atômica, forneceram subsídios para a determinação das impurezas presentes no fosfogesso puro e nas misturas de fosfogesso e cal propostas na pesquisa, através do extrato lixiviado e solubolizado.

\subsection{ANÁLISE ESTATÍSTICA DOS RESULTADOS}

\subsubsection{Método para aceitação dos corpos-de-prova}

Os resultados obtidos nos ensaios para determinação das propriedades mecânicas dos materiais foram analisados com base nos valores estatísticos de média e desvio padrão, sendo aplicado o teste de Grubbs para identificação de outliers (GRUBBS, 1969). 
Para aplicação do teste de Grubbs primeiro deve-se verificar que os dados podem ser razoavelmente representados por uma distribuição normal. $\mathrm{O}$ teste de Grubbs está definido pelas seguintes hipóteses: hipótese nula $\left(\mathrm{H}_{0}\right)$, não existe nenhum outlier nos resultados dos ensaios; hipótese alternativa $\left(H_{1}\right)$, existe pelo menos um outlier nos resultados dos ensaios. Este teste detecta um outlier cada vez que é realizado, mesmo que é eliminado dos dados e o teste repete-se até que não sejam detectados outliers. Para a aplicação deste teste deve-se verificar dentre os dados de um mesmo tratamento quais são os valores máximo e mínimo. A partir destes valores calcula-se o valor estatístico $G$ definido pela equação.

$$
G=\frac{\max \left|y_{i}-\bar{y}\right|}{S}
$$

onde:

$\mathrm{y}_{\mathrm{i}}=$ valores máximo e mínimo dentro do conjunto de resultados de um mesmo tratamento;

$\bar{y}=$ média dos resultados de um mesmo tratamento;

$\mathbf{S}=$ desvio padrão dos resultados de um mesmo tratamento.

$O$ valor estatístico $G$ deve ser comparado com o valor $G_{\text {critico }}$ que depende do número de repetições $(\mathrm{N})$ e grau de confiança $(\alpha)$ o resultado é considerado um outlier quando $\mathrm{G}>\mathrm{G}_{\text {crítico. }}$.

Para este trabalho adotou-se nível de confiança de $95 \%$ e foram feitas quatro observações para cada ensaio, sendo o $G_{\text {critico }}$ utilizado 1,15 .

\subsubsection{Análise de variância}

Foi feita a análise de variância dos resultados de compressão simples e compressão diametral verificando-se a influência do teor de cal na mistura, bem como o tempo de cura. 
A análise de variância é um procedimento estatístico comum para comparação simultânea de médias populacionais, que permite realizar o teste de hipótese e verificar a hipótese de que o efeito sob consideração é significante. Deve-se destacar que a aceitação de uma hipótese simplesmente implica que os dados não apresentam suficientes evidências para rejeitá-la.

Um teste de hipótese estatístico é o critério que permite a aceitação ou rejeição da hipótese em consideração. A validade dos testes estatísticos depende da existência de réplicas, pois estas fornecem uma estimativa do erro aleatório, e tornam possível o uso de tabelas de significância, construídas sob a consideração de que os erros são independentes (GARCIA-DIAZ \& PHILLIPS, 1995). 


\section{APRESENTAÇÃO E ANÁLISE DOS RESULTADOS}

\subsection{INTRODUÇÃO}

A investigação experimental foi conduzida para se avaliar o desempenho mecânico de misturas compactadas constituídas de fosfogesso e cal, combinados segundo diferentes proporções. Para a composição das misturas, foram escolhidos os seguintes teores de cal: 0\%, 3\% 5\% 7\% e 10\% em relação à massa seca do fosfogesso.

\subsection{ANÁlise DOS RESULTADOS DOS ENSAIOS DE COMPACTAÇÃO}

Os ensaios de compactação das misturas de fosfogesso e cal foram realizados na energia modificada do ensaio de Proctor para a determinação dos correspondentes valores de massa específica seca máxima $\left(\rho_{\mathrm{dmax}}\right)$ e umidade ótima $\left(\omega_{0}\right)$. A Tabela 4.1 apresenta os valores de $\rho_{\mathrm{dmax}}$ e $\omega_{\mathrm{o}}$ para as misturas estudadas e a Figura 4.1, as curvas de compactação correspondentes.

TABELA 4.1 - Massa específica seca máxima e umidade ótima das misturas de fosfogesso e cal

\begin{tabular}{cccc}
\hline Mistura & $\begin{array}{c}\rho_{\text {dmax }} \\
\text { Fosfogesso (\%) }\end{array}$ & $\begin{array}{c}\boldsymbol{\omega}_{\circ} \\
\left(\mathbf{g} / \mathbf{c m}^{3}\right)\end{array}$ & $\mathbf{( \% )}$ \\
\hline 100 & 0 & 1,645 & 12,1 \\
97 & 3 & 1,505 & 16,4 \\
95 & 5 & 1,495 & 16,4 \\
93 & 7 & 1,505 & 15,2 \\
90 & 10 & 1,510 & 14,8 \\
\hline
\end{tabular}




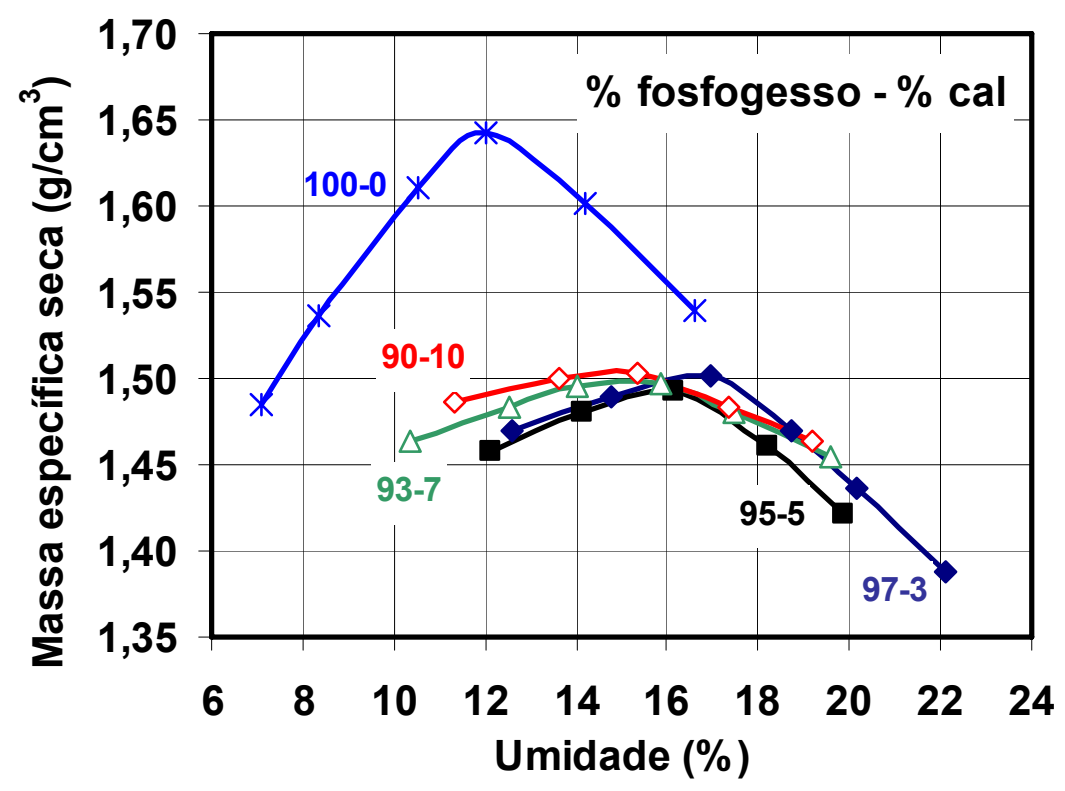

FIGURA 4.1 - Curvas de compactação das misturas de fosfogesso e cal

Analisando-se a forma das curvas de compactação apresentadas na Figura 4.1, observa-se, que de forma geral, a adição de cal conduz a uma suavização destas. Este fato indica que a $\rho_{\mathrm{dmax}}$ das misturas com cal são menos sensíveis à variação da umidade de compactação do que o fosfogesso puro.

Ainda considerando-se o efeito da adição cal nos resultados dos ensaios de compactação, as Figuras 4.2 e 4.3 ilustram respectivamente, a variação da massa específica seca máxima e a variação da umidade ótima com o teor de estabilizante utilizado na mistura.

Analisando-se os valores apresentados na Tabela 4.1 e as Figuras 4.2 e 4.3, observa-se que a adição de cal conduz a uma diminuição de $\rho_{d m a x}$ e um aumento da $\omega_{0}$. Para a massa específica seca máxima, a adição de $3 \%, 5 \%$, $7 \%$ e $10 \%$ de cal, provocam respectivamente, uma diminuição de $\rho_{\text {dmáx }}$ de $9,3 \%, 10 \%, 9,3 \%$ e $8,9 \%$ com relação a $\rho_{\text {dmáx }}$ do fosfogesso puro. Quanto à umidade ótima, o aumento é de $35,5 \%, 35,5 \%, 25,6 \%$ e $22,3 \%$, considerados os mesmos teores de cal. Assim, o efeito da adição da cal ao fosfogesso é similar ao já verificado em outras pesquisas onde este estabilizante foi utilizado com solo. 


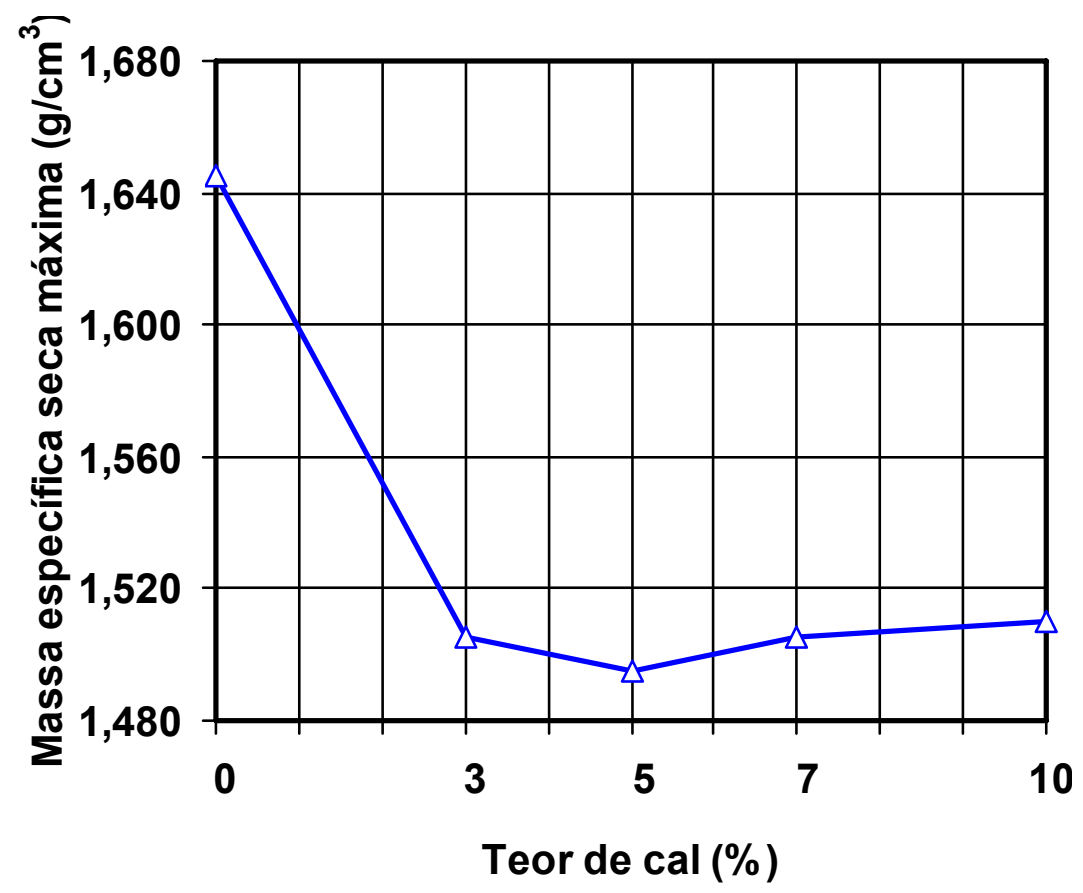

FIGURA 4.2 - Massa específica seca máxima em função do teor de cal

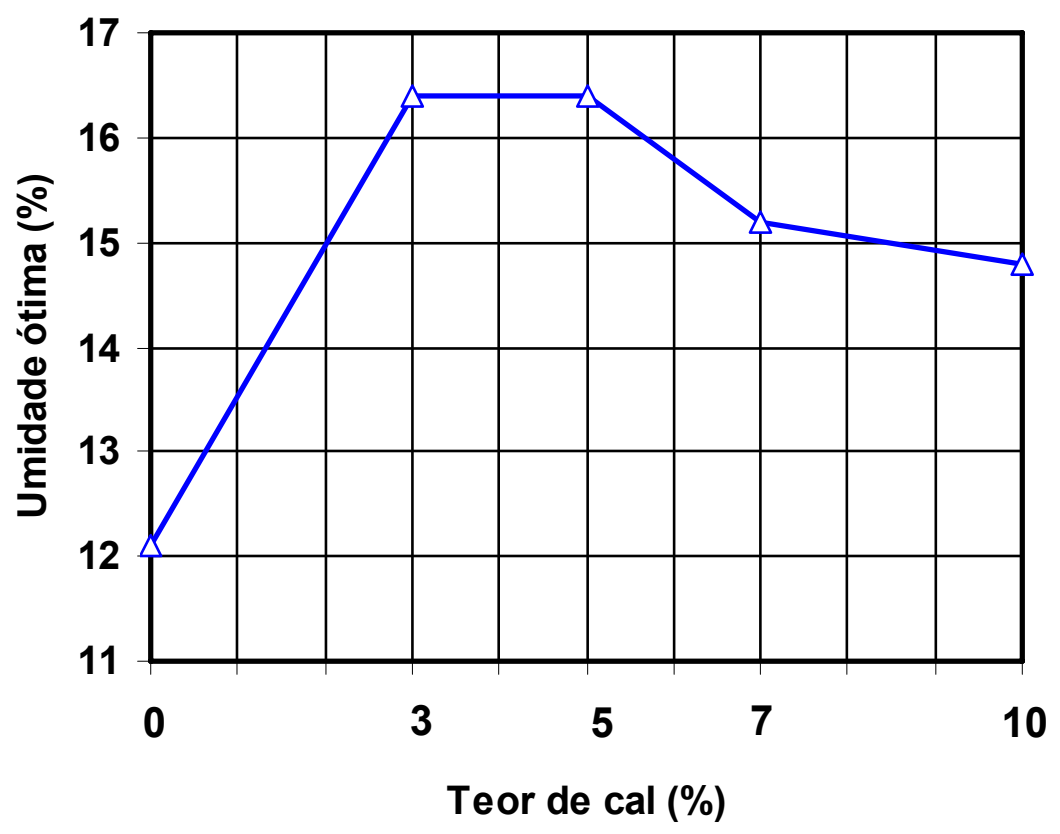

FIGURA 4.3 - Umidade ótima em função do teor de cal

Entretanto, é importante destacar, que para as misturas com fosfogesso, após a diminuição de $\rho_{\mathrm{dmax}}$ e o aumento da $\omega_{\mathrm{o}}$ expressivos com a adição inicial de $3 \%$ de cal, as tendências de variação destes parâmetros com o aumento da quantidade de estabilizante não se conservam, visto que $\circ \rho_{\mathrm{dmax}}$ diminui ligeiramente no intervalo de $3 \%$ a $5 \%$, e mantém-se praticamente constante para as demais porcentagens. No tocante à $\omega_{0}$, após o crescimento inicial, 
mantém-se constante no intervalo de $3 \%$ a $5 \%$, diminuindo para as demais porcentagens. Este comportamento difere do observado comumente para misturas solo-cal, para as quais a tendência de diminuição de $\rho_{\mathrm{dmax}}$ e aumento da $\omega_{0}$ conserva-se inalterada para teores crescentes de estabilizante.

Comparando-se os resultados obtidos nesta pesquisa com os determinados por Molina (2004), que estudou misturas compostas com um solo arenoso e outro argiloso, estabilizadas com 5\% e 10\% de cal, observa-se que misturas de fosfogesso e cal apresentam massas específicas secas máximas inferiores às das misturas solo-cal para os mesmos teores de cal, visto que o $\rho_{\text {dmáx }}$ das primeiras situam-se no intervalo de $1,495 \mathrm{~g} / \mathrm{cm}^{3}$ a $1,510 \mathrm{~g} / \mathrm{cm}^{3}$, enquanto que Molina (2004) determinou valores no intervalo de $1,720 \mathrm{~g} / \mathrm{cm}^{3}$ a $1,850 \mathrm{~g} / \mathrm{cm}^{3}$. Quanto à umidade ótima, os intervalos de variação para os dois tipos de misturas sobrepõe-se, pois as misturas solo-cal e as compostas com fosfogesso apresentam valores de $\omega_{0}$ situados nos intervalos de $12,5 \%$ a $17,2 \%$ e $16,4 \%$ a $14,8 \%$, respectivamente.

Comparando-se os resultados obtidos nesta pesquisa com os determinados por Silvestre (2002) para misturas de fosfogesso estabilizadas com $5 \%$ e $10 \%$ de cimento do tipo CP II E-32, observa-se que os valores de massa específica seca máxima correspondentes a estas últimas misturas, situados no intervalo de $1,345 \mathrm{~g} / \mathrm{cm}^{3}$ a $1,366 \mathrm{~g} / \mathrm{cm}^{3}$, são menores que os obtidos para misturas de fosfogesso e cal. No tocante à umidade ótima, observa-se que os valores correspondentes às misturas aqui estudadas são menores do que os valores determinados para as misturas de fosfogesso e cimento, cujas $\omega_{\mathrm{o}}$ situam-se no intervalo de $17,7 \%$ a $18,5 \%$.

\subsection{PROPRIEDADES MECÂNICAS DAS MISTURAS}

Os resultados aqui descritos e analisados referem-se aos ensaios de compressão simples, compressão diametral e CBR realizados visando avaliar as propriedades mecânicas das misturas estudadas.

\subsubsection{Resistência à compressão simples}

A resistência à compressão simples é o critério mais utilizado em pavimentação para se avaliar a adequabilidade de misturas estabilizadas para 
a construção de bases e sub-bases rodoviárias. A diferença de resistência à compressão simples entre a mistura sem cal e a mistura com cal tem sido adotado como um indicador para determinar se o material é ou não reativo à cal: ganhos substanciais de resistência indicam que o solo é reativo e provavelmente produzirá um material de pavimentação de qualidade.

Segundo os Procedimentos de Thompson e Illinois apresentados na State of the Art 5 - Lime Stabilization (TRB, 1987), o solo estabilizado com cal deve apresentar um aumento na resistência à compressão simples de $350 \mathrm{kPa}$ em relação ao solo natural para o mesmo ser considerado reativo à cal. Além de serem reativas, as misturas devem enquadrar-se acima de limites no tocante às resistências mínimas para construção de camadas de base e subbase, estabelecidas respectivamente, como $1000 \mathrm{kPa}$ e $700 \mathrm{kPa}$, valores determinados após 28 dias de cura a $20^{\circ} \mathrm{C}$.

O Anexo A apresenta os valores de resistência à compressão simples de cada corpo-de-prova e o Anexo E, as correspondentes médias obtidas segundo o método estatístico de GRUBBS aplicado às réplicas ensaiadas.

A Tabela 4.2 apresenta a resistência à compressão simples das misturas de fosfogesso e cal, para os teores de cal, tempo de cura e condições de ensaios considerados na pesquisa. Nesta tabela são também apresentado o aumento ou diminuição da resistência, respectivamente com a adição da cal ou a imersão em água, e as correspondentes porcentagens de ganho ou perda determinadas em relação à resistência do fosfogesso puro e a de corpos-deprova ensaiados sem imersão. 
TABELA 4.2 - Resistência à compressão simples e a sua variação

\begin{tabular}{|c|c|c|c|c|c|c|c|}
\hline & & \multicolumn{3}{|c|}{ Sem imersão } & \multicolumn{3}{|c|}{ Após imersão } \\
\hline $\begin{array}{l}\text { Tempo } \\
\text { de } \\
\text { cura } \\
\text { (dias) }\end{array}$ & $\begin{array}{l}\text { Teor } \\
\text { de } \\
\text { cal } \\
(\%)\end{array}$ & $\begin{array}{l}\text { RCS } \\
\text { (kPa) }\end{array}$ & $\begin{array}{c}\text { Diferença } \\
\text { RCS } \\
\text { (kPa) }\end{array}$ & $\begin{array}{c}\text { Ganho } \\
\text { RCS } \\
(\%)\end{array}$ & $\begin{array}{l}\text { RCS } \\
(\mathrm{kPa})\end{array}$ & $\begin{array}{c}\text { Diferença } \\
\text { RCS } \\
\text { (kPa) }\end{array}$ & $\begin{array}{c}\text { Perda } \\
\text { por } \\
\text { imersão } \\
\text { RCS } \\
(\%)\end{array}$ \\
\hline \multirow{5}{*}{0} & 0 & 530 & & & *nd & & \\
\hline & 3 & 473 & -57 & $-10,75$ & nd & nd & nd \\
\hline & 5 & 510 & -20 & $-3,77$ & nd & nd & nd \\
\hline & 7 & 659 & 129 & 24,34 & nd & nd & nd \\
\hline & 10 & 715 & 185 & 34,90 & nd & nd & nd \\
\hline \multirow{5}{*}{3} & 0 & 550 & & & nd & & \\
\hline & 3 & 572 & 22 & 4 & 324 & 248 & 43 \\
\hline & 5 & 594 & 44 & 8 & 353 & 241 & 41 \\
\hline & 7 & 693 & 143 & 26 & 475 & 218 & 31 \\
\hline & 10 & 754 & 204 & 37 & 506 & 248 & 33 \\
\hline \multirow{5}{*}{7} & 0 & 561 & & & nd & & \\
\hline & 3 & 585 & 24 & 4,27 & 363 & 222 & 38 \\
\hline & 5 & 606 & 45 & 8 & 395 & 211 & 35 \\
\hline & 7 & 715 & 154 & 27,45 & 565 & 150 & 21 \\
\hline & 10 & 854 & 293 & 52 & 630 & 224 & 26 \\
\hline \multirow{5}{*}{28} & 0 & 580 & & & nd & & \\
\hline & 3 & 691 & 111 & 19 & 546 & 145 & 21 \\
\hline & 5 & 810 & 230 & 40 & 622 & 188 & 23 \\
\hline & 7 & 858 & 278 & 48 & 712 & 146 & 17 \\
\hline & 10 & 1022 & 442 & 76 & 844 & 178 & 17 \\
\hline
\end{tabular}

${ }^{*}$ nd - não determinado

\subsubsection{A influência do teor de cal}

As Figuras 4.4 e 4.5 ilustram a variação da resistência à compressão simples com o teor de cal, para ensaios realizados sem imersão e após imersão prévia em água, respectivamente. Complementarmente, as Figuras 4.6 e 4.7 apresentam estas mesmas variáveis através de diagrama de barras. 


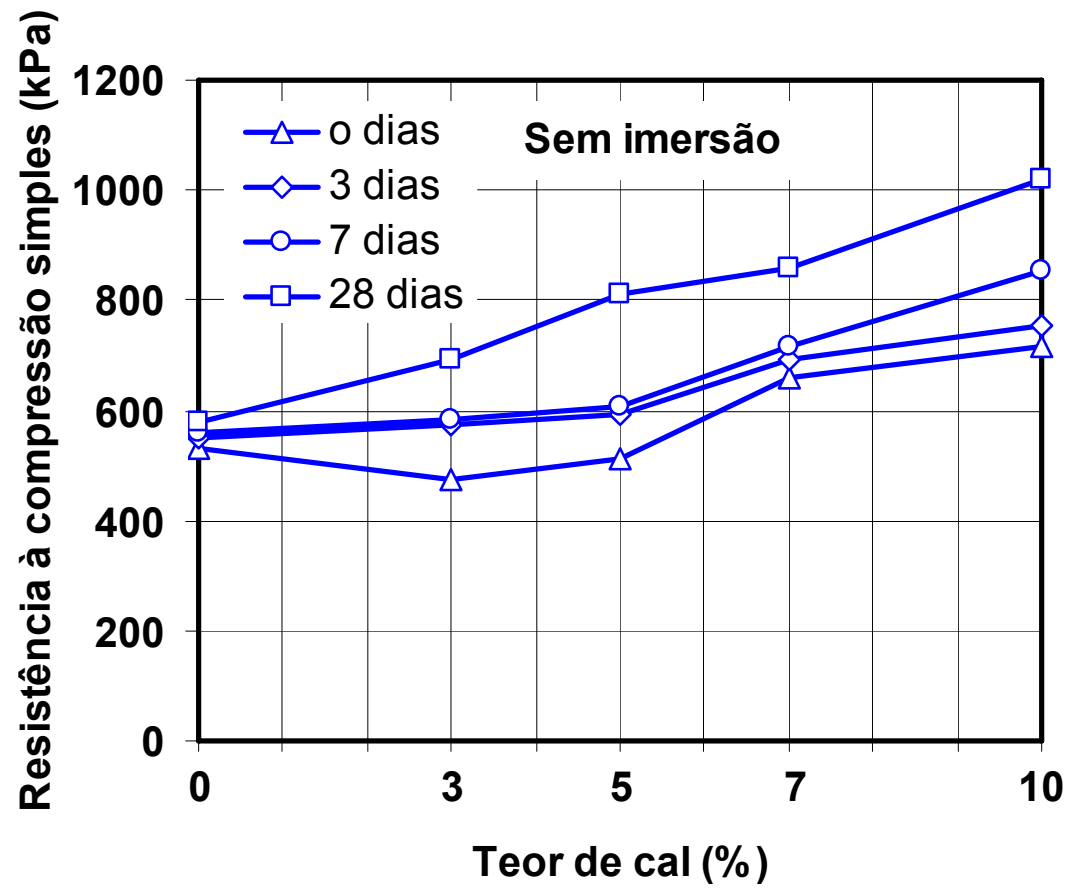

FIGURA 4.4 - Variação da resistência à compressão simples para misturas de fosfogesso e cal ensaiadas sem imersão

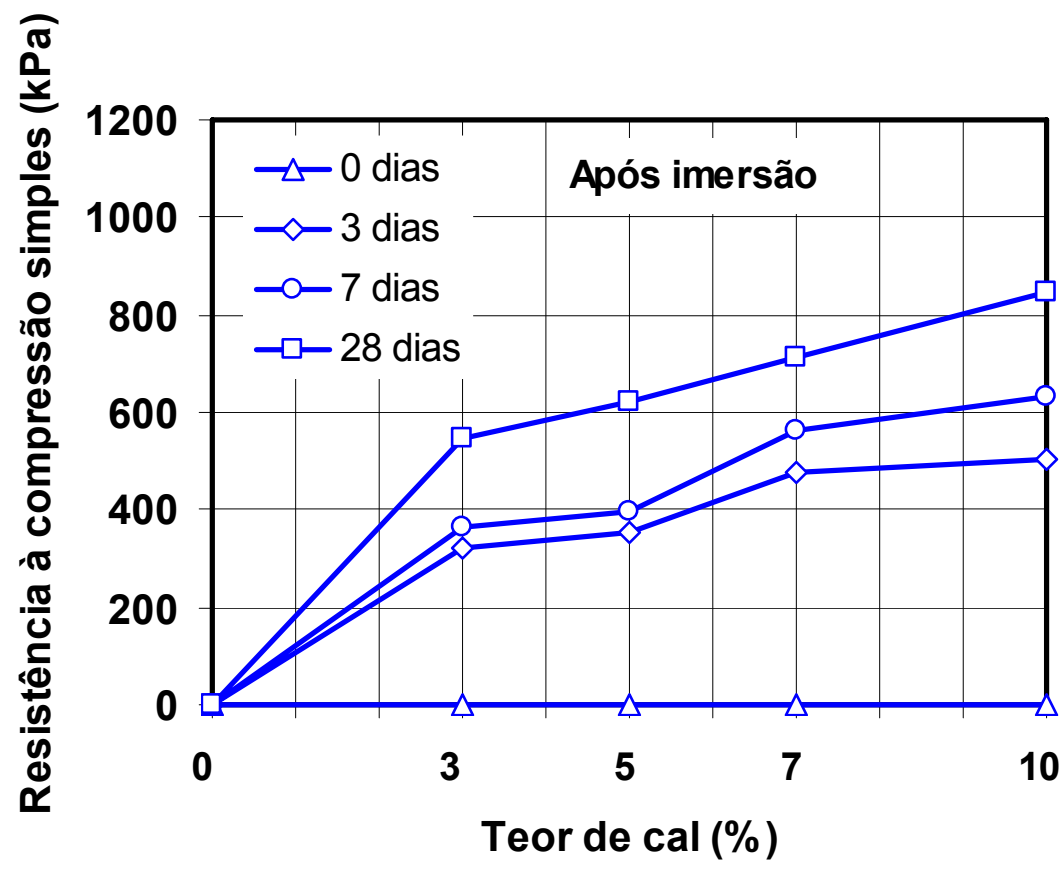

FIGURA 4.5 - Variação da resistência à compressão simples para misturas de fosfogesso e cal ensaiadas após imersão 


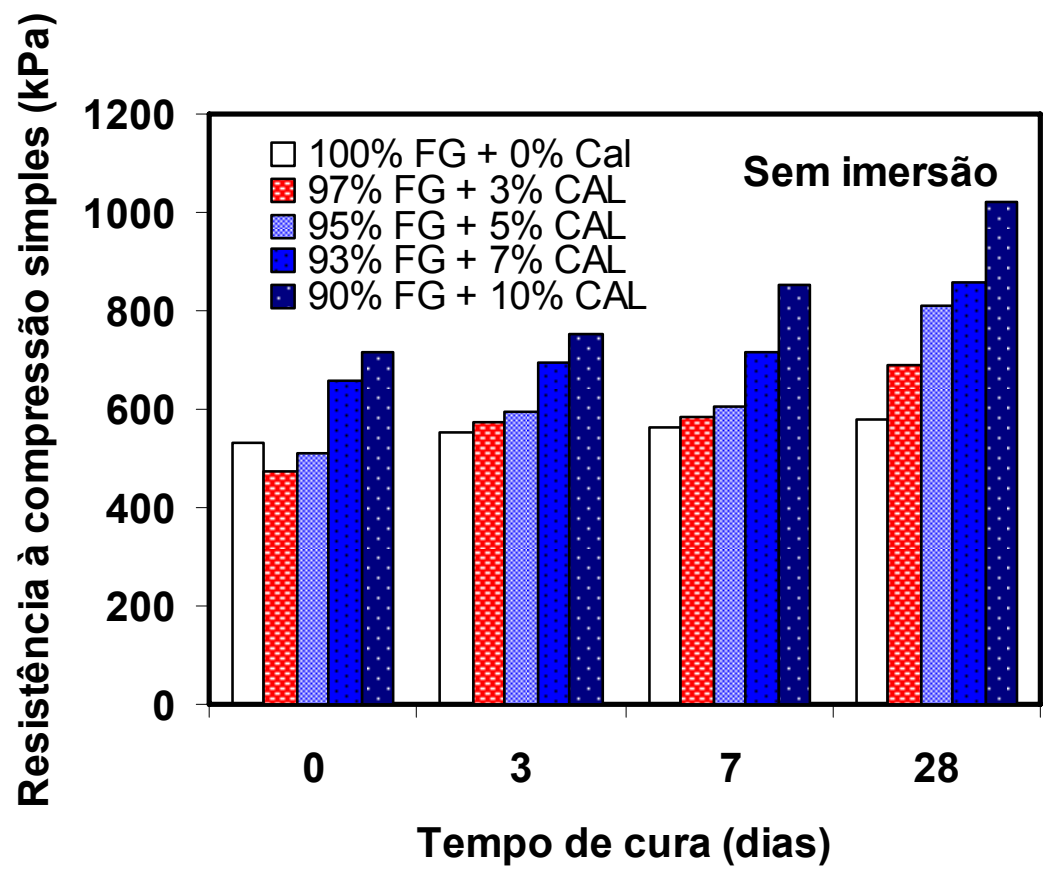

FIGURA 4.6 - Diagrama de barras - variação da resistência à compressão simples para misturas de fosfogesso e cal ensaiadas sem imersão

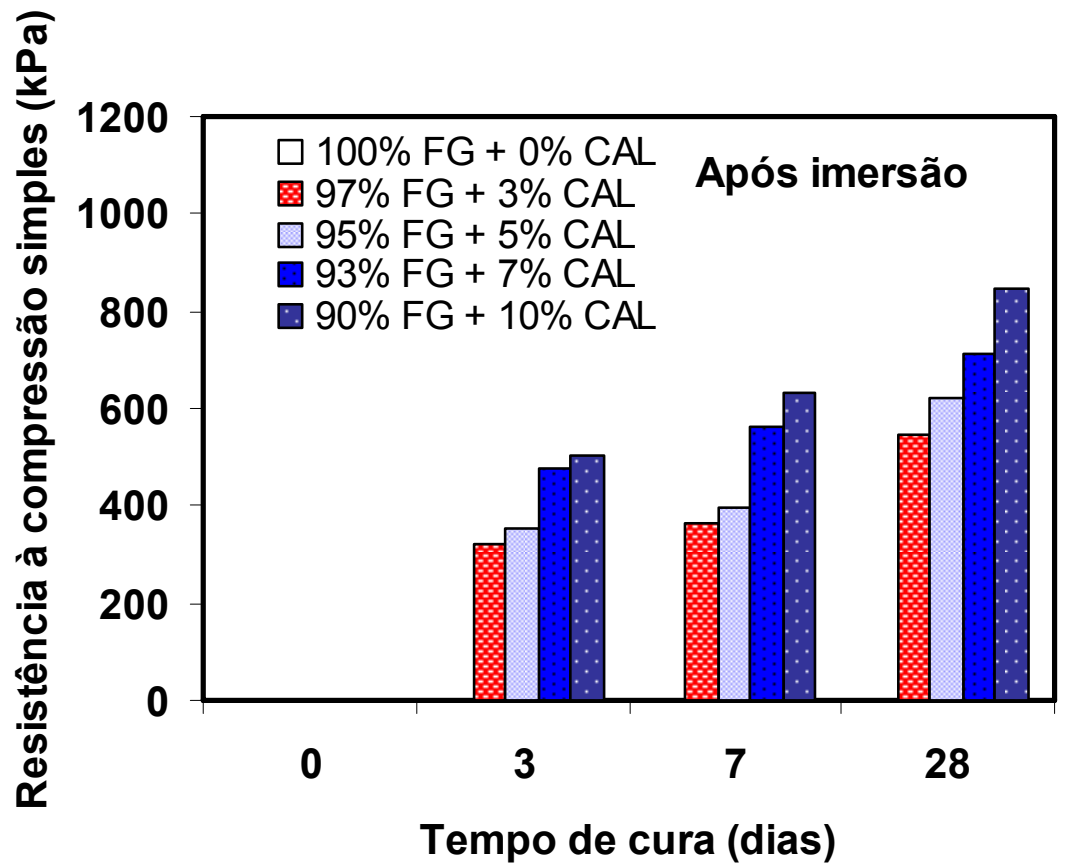

FIGURA 4.7 - Diagrama de barras - variação da resistência à compressão simples para misturas de fosfogesso e cal ensaiadas após imersão

Analisando-se os valores apresentados na Tabela 4.2 e as Figuras 4.4, 4.5, 4.6 e 4.7, observa-se que a adição de cal conduz ao aumento da resistência à compressão simples (RCS), à exceção das misturas não curadas 
e ensaiadas sem e após imersão em água. Levando-se em consideração os ensaios realizados sem imersão conforme ilustrado nas Figuras 4.4 e 4.6 e considerando-se valores médios calculados a partir dos resultados correspondentes a 3, 7 e 28 dias de cura, o ganho de resistência em relação ao fosfogesso puro de é de $9 \%, 19 \%, 34 \%$ e $55 \%$, respectivamente para os teores de $3 \%, 5 \%, 7 \%$ e $10 \%$ de cal.

Para os ensaios realizados após imersão em água, e conforme ilustrado nas Figuras 4.5 e 4.7, observa-se que o efeito positivo da adição de cal é ainda mais evidente, visto que a totalidade dos corpos-de-prova constituídos apenas por fosfogesso desintegrarem-se para todos os tempos de cura, não permitindo a execução dos ensaios. Quando se analisa a ação da água sobre o fosfogesso estabilizado, e considerando-se valores médios calculados a partir dos tempos de cura de 3, 7 e 28 dias, a redução da RCS é de 34\%, 33\%, 23\% e $25 \%$, para os teores de $3 \%, 5 \%, 7 \%$ e $10 \%$ de cal, respectivamente.

Os diagramas das Figuras 4.6 e 4.7 ilustram que o efeito positivo da cal torna-se realmente significativo para o teor de $3 \%$, a partir do qual o acréscimo da resistência à compressão simples mantém-se crescente até os 28 dias de cura. Observa-se ainda que, para todos os teores de cal e para as duas condições de ensaio, as maiores resistências são alcançadas aos 28 dias.

Para se compararem entre os efeitos da adição da cal ao solo com os da sua adição ao fosfogesso, a Tabela $\mathbf{4 . 3}$ apresenta valores de RCS determinados nesta pesquisa e por Molina (2004) para misturas de dois tipos de solo e $5 \%$ e $10 \%$ de cal, ensaiadas sem imersão em água.

Analisando-se os valores apresentados na Tabela 4.3, observa-se que, à exceção da amostra de solo argiloso estabilizada com $5 \%$ de cal, as misturas de fosfogesso e cal apresentaram valores mais elevados de resistência a compressão simples, consideradas a mesmas condições. Comparando-se os valores médios calculados a partir das resistências correspondentes a todas as condições ensaiadas, as misturas de fosfogesso estabilizadas com cal apresentam RCS superior em $21 \%$ à das misturas de solo cal. 
TABELA 4.3 - Resistência à compressão simples de misturas de solo e cal, e fosfogesso e cal

\begin{tabular}{ccc}
\hline Material & Teor de cal (\%) & RCS aos 7 dias de cura \\
\hline \multirow{2}{*}{ Solo arenoso } & 5 & 426 \\
& 10 & 296 \\
\hline \multirow{2}{*}{ Solo argiloso } & 5 & 761 \\
& 10 & 706 \\
\hline \multirow{2}{*}{ Fosfogesso } & 5 & 606 \\
& 10 & 854 \\
\hline
\end{tabular}

Para a comparação entre os efeitos da adição da cal e do cimento ao fosfogesso, a Tabela 4.4 apresenta valores de RCS determinados nesta pesquisa e por Silvestre (2002) para misturas de fosfogesso estabilizado com $5 \%$ e $10 \%$ do cimento CP II-E 32, ensaiadas sem imersão e após imersão em água.

TABELA 4.4 - Resistência à compressão simples de misturas de fosfogesso e cal, e fosfogesso e cimento

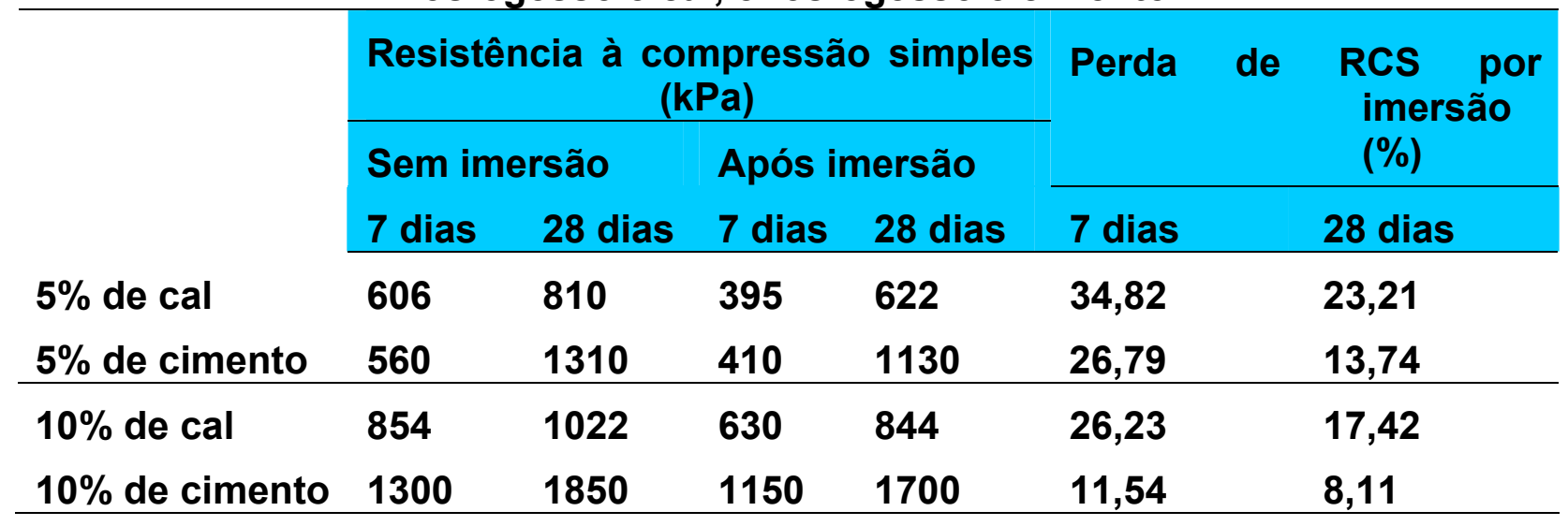

Analisando-se os valores apresentados na Tabela 4.4, observa-se que, à exceção das amostras com $5 \%$ de cal, curadas por 7 dias e ensaiadas sem imersão, todas as misturas de fosfogesso e cimento apresentaram RCS superiores as das misturas estudadas nesta pesquisa. Comparando-se os valores médios calculados a partir das resistências correspondentes a todas as condições ensaiadas, as misturas estabilizadas com cal apresentam RCS 70\% inferior à das misturas estabilizadas com cimento. Assim, a vantagem do menor custo da cal, aproximadamente $30 \%$ inferior ao do cimento, ficaria minimizada se for considerado apenas este aspecto. 


\subsubsection{A influência do tempo de cura}

O tempo de cura é um fator importante no desenvolvimento da resistência de misturas estabilizadas com cal. As Figuras 4.8 e 4.9 ilustram, respectivamente, a variação da resistência à compressão simples com o tempo de cura para corpos de provas ensaiados sem imersão e após imersão prévia em água. Complementarmente, as Figuras 4.10 e 4.11 apresentam estas mesmas variáveis através de diagrama de barras.

Analisando-se os valores da Tabela 4.2 e as Figura 4.8, 4.9, 4.10 e 4.11, observa-se que o acréscimo do tempo de cura conduz ao aumento de resistência para todos os teores de cal e para as duas condições de ensaio. Para os ensaios realizados sem imersão, vide Figuras 4.8 e 4.10, e considerando-se valores médios calculados a partir dos resultados correspondentes a todos os teores de cal, excetuando o fosfogesso puro, observa-se que o ganho de resistência à compressão simples em relação às amostras ensaiadas sem cura é de $11 \%, 17 \%$ e $43 \%$, para os tempos de cura 3, 7 e 28 dias, respectivamente. Assim, conclui-se que apenas após 28 dias de cura, o ganho de RCS com o tempo de cura torna-se realmente expressivo. A não observação do efeito positivo da cal em corpos de prova ensaiados imediatamente após compactação indica que a ação do aditivo a curto prazo (troca cátion-iônica) não se processa, restando apenas o efeito da cimentação (reação pozolânica da cal com o fosfogesso), que se dá a longo prazo. Neste sentido, Graves (1987) já observara que a ação cimentante da cal sobre materiais calcários, a exemplo do fosfogesso, é muito elevada.

Para os ensaios realizados após imersão em água, vide Figuras 4.9 e 4.11, a importância da cura torna-se ainda mais evidente, pois todos os corpos de prova não curados desintegraram-se durante o processo. Nestas condições e considerando-se valores médios calculados a partir dos resultados correspondentes a todos os teores de cal, o ganho de RCS nos períodos de 3 a 7 dias, e de 3 a 28 dias, é de $18 \%$ e $64 \%$, respectivamente. 


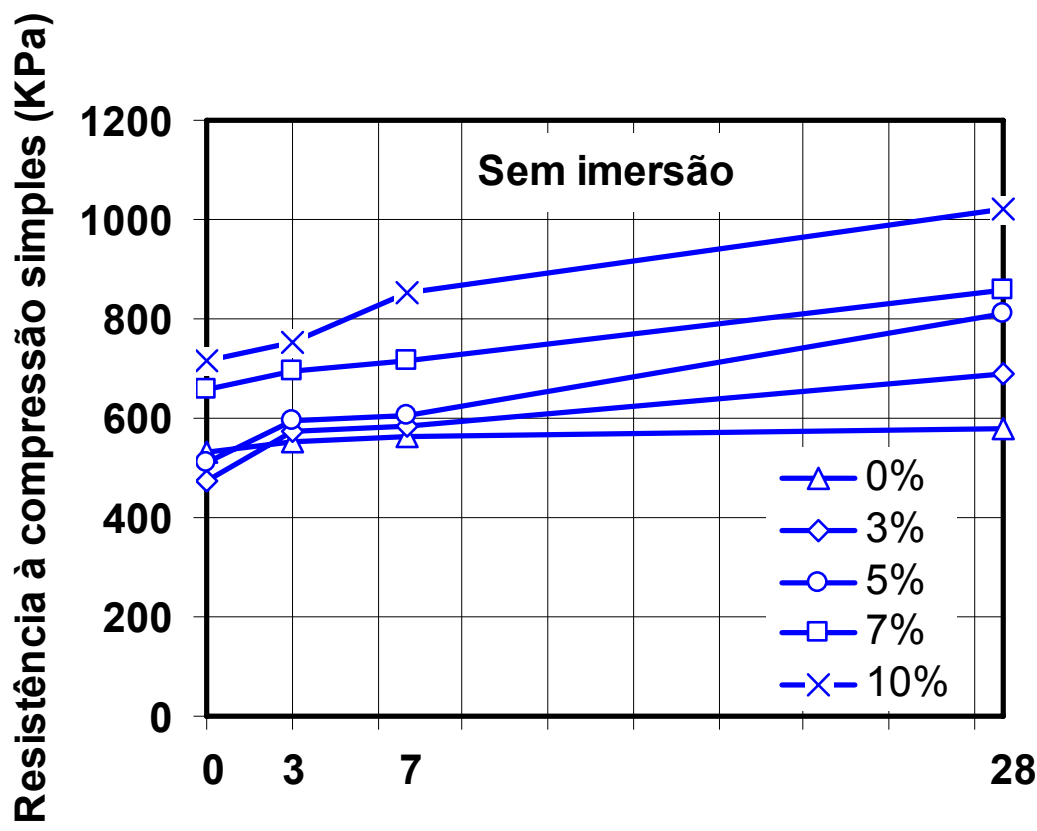

Tempo de cura (dias)

FIGURA 4.8 - Variação da resistência à compressão simples para misturas de fosfogesso e cal ensaiadas sem imersão

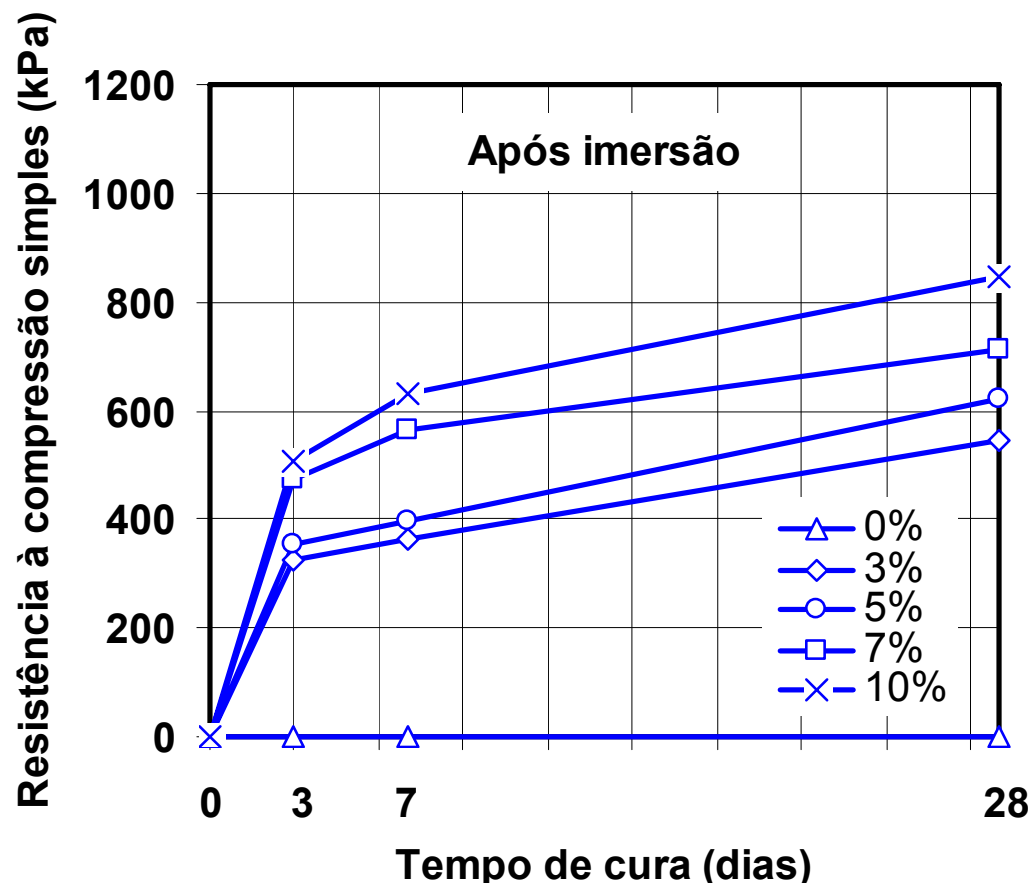

FIGURA 4.9 - Variação da resistência à compressão simples para misturas de fosfogesso e cal ensaiadas após imersão 


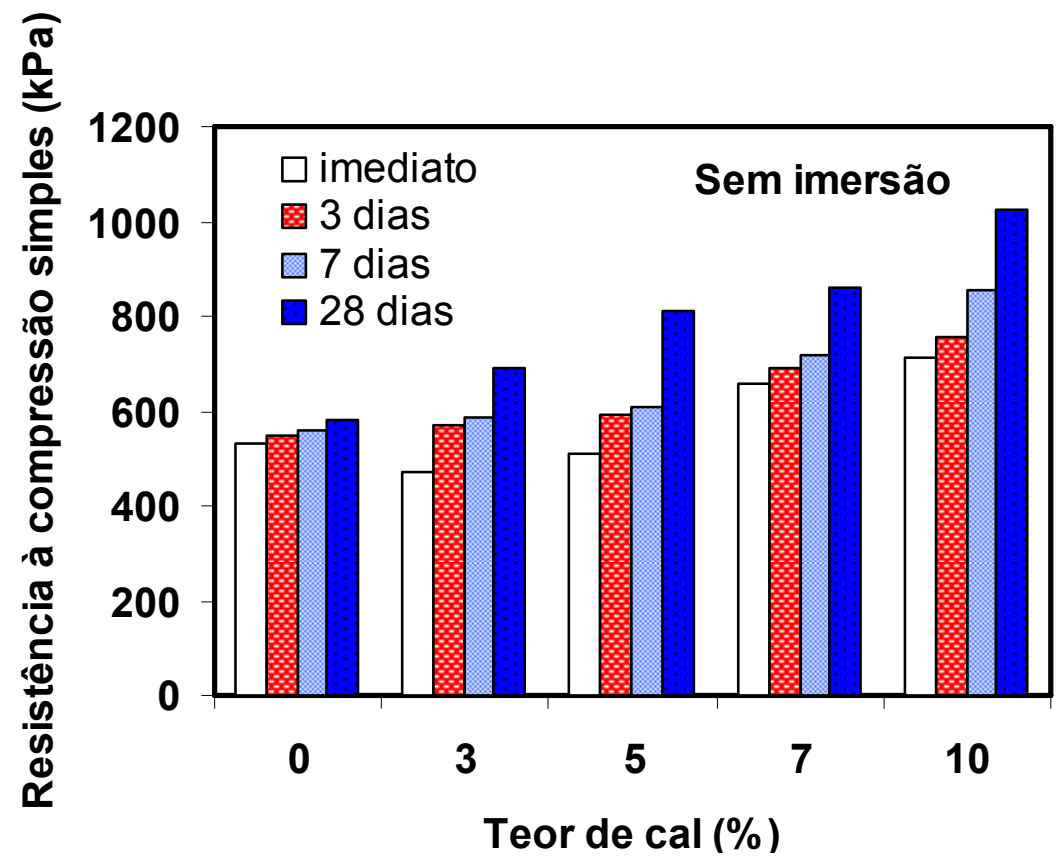

FIGURA 4.10 - Diagrama de barras - variação da resistência à compressão simples para misturas de fosfogesso e cal ensaiadas sem imersão

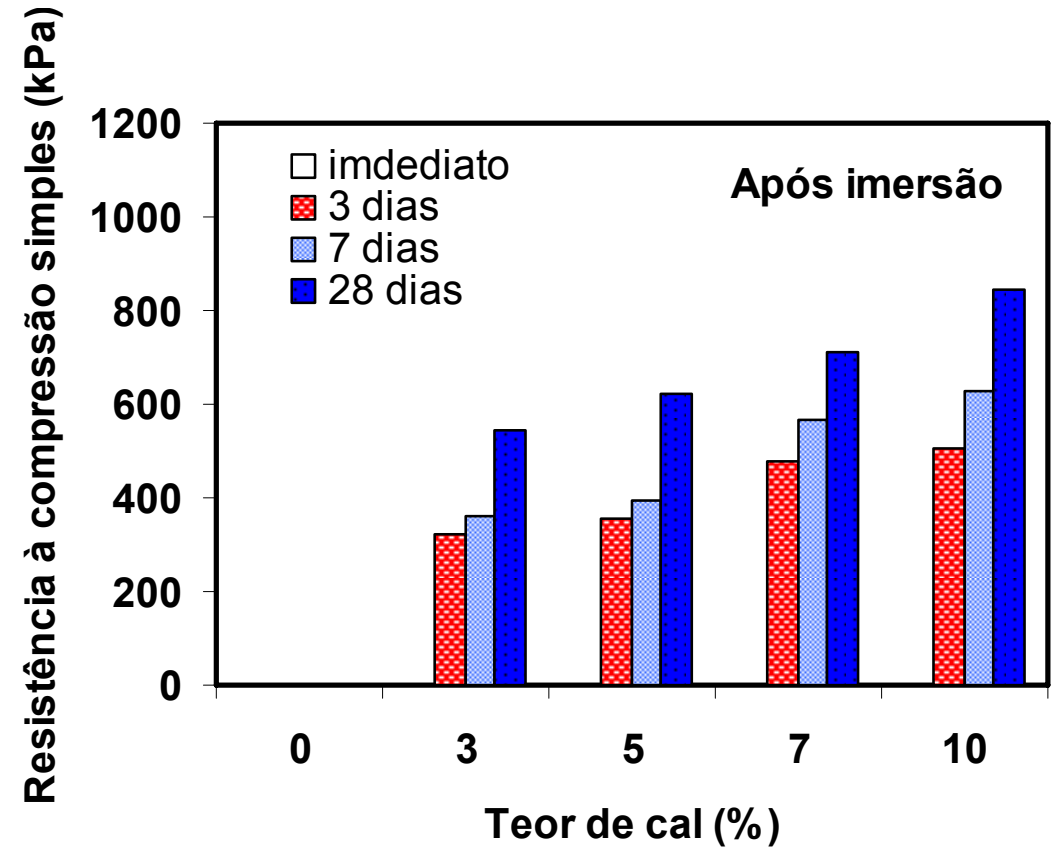

FIGURA 4.11 - Diagrama de barras - variação da resistência à compressão simples para misturas de fosfogesso e cal ensaiadas após imersão

Comparando-se os valores de resistência obtidos nesta pesquisa com os valores determinados por Silvestre (2002) para misturas fosfogesso e cimento, conforme apresentado na Tabela 4.4, observa-se que o efeito do tempo de 
cura é mais marcante para esta última mistura do que para as misturas de fosfogesso estabilizadas com cal.

Finalmente, considerando-se o Procedimento Illinois apresentado no State of the Art 5 - Lime Stabilization (TRB, 1987), que estabelece para misturas solo-cal, as resistências mínimas de 1030 kPa e 690 kPa, valores determinados após 30 dias de cura a $20^{\circ} \mathrm{C}$, respectivamente para a construção de camadas de base e sub-base, observa-se que as misturas de fosfogesso e $5 \%$ e $10 \%$ de cal atendem, respectivamente, o primeiro e o segundo limite, conforme os valores apresentados na Tabela 4.2, para cura de 28 dias, sem imersão.

\subsubsection{Relação entre resistência à compressão simples, o tempo de cura, e o teor de cal}

Foram realizadas regressões múltiplas, utilizando-se a resistência à compressão simples como variável dependente e o tempo de cura e o teor de cal como variáveis independentes. Assim, determinaram-se as Equações $4.1 \mathrm{e}$ 4.2 considerando-se, respectivamente, os resultados das misturas ensaiadas sem imersão e após imersão previa em água.

$$
\begin{array}{ll}
\mathrm{RCS}=323,13 \cdot(\mathrm{TC})^{0,12} \cdot(\mathrm{cal})^{0,31} & \mathrm{R}^{2}=0,94 \\
\mathrm{RCS}=151,51 \cdot(\mathrm{TC})^{0,22} \cdot(\mathrm{cal})^{0,42} & \mathrm{R}^{2}=0,96
\end{array}
$$

onde:

RCS - resistência à compressão simples $(\mathrm{kPa})$;

TC - tempo de cura (dias);

(cal) - variação do teor de cal.

Com estas equações apresentadas acima, pretendeu-se analisar se os valores obtidos de RCS neste modelo proposto são equivalentes aos obtidos com os valores em laboratório. Vale salientar que foi excluído o tempo de cura de zero dias, bem como o teor de $0 \%$ de cal para este modelo proposto. A influência do teor de cal, tempo de cura e condição de ensaio foi festa pela análise de variância.

As Equações 4.1 e 4.2 apresentam coeficientes de determinação $\left(R^{2}\right)$ iguais a 0,94 e 0,96 , respectivamente. Os valores elevados de $R^{2}$ indicam que 
estas equações representam com fidelidade a relação entre as variáveis consideradas. Este fato também é evidenciado analisando-se as Figuras 4.12 e 4.13 que apresentam valores de RCS calculados a partir das Equações 4.1 e 4.2, respectivamente, e os valores correspondentes determinados nos ensaios de laboratório.

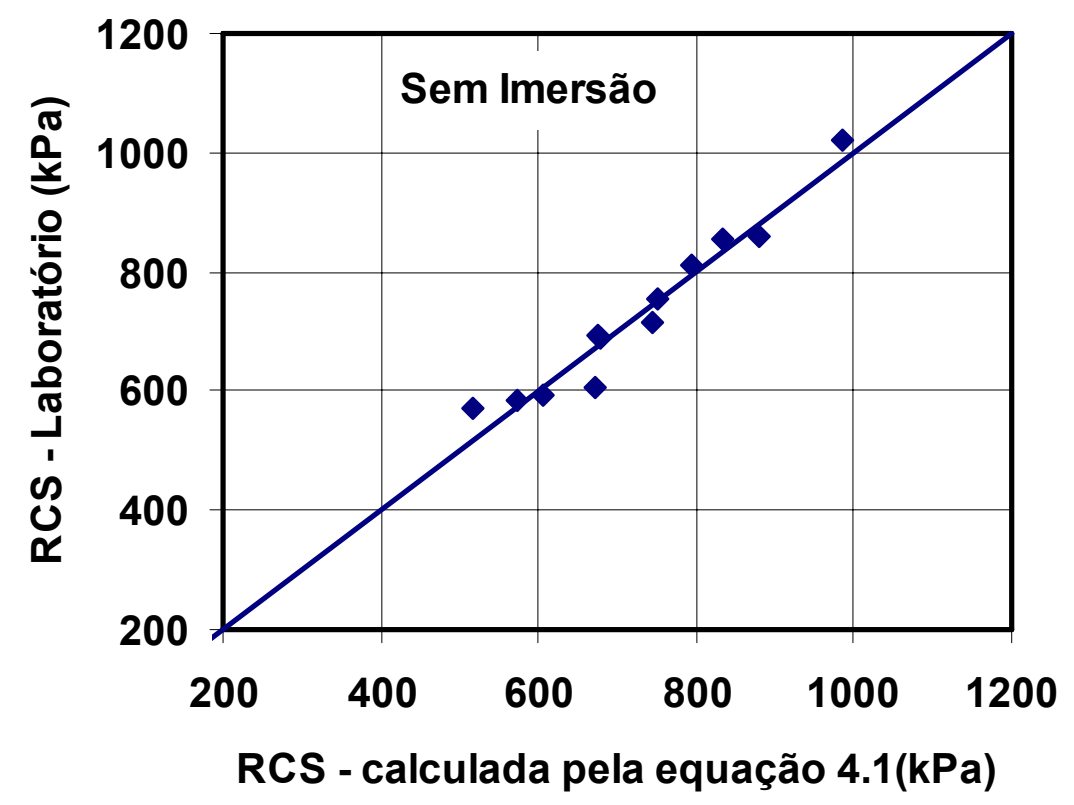

FIGURA 4.12 - Valores de RCS: equação 4.1 "versus" laboratório

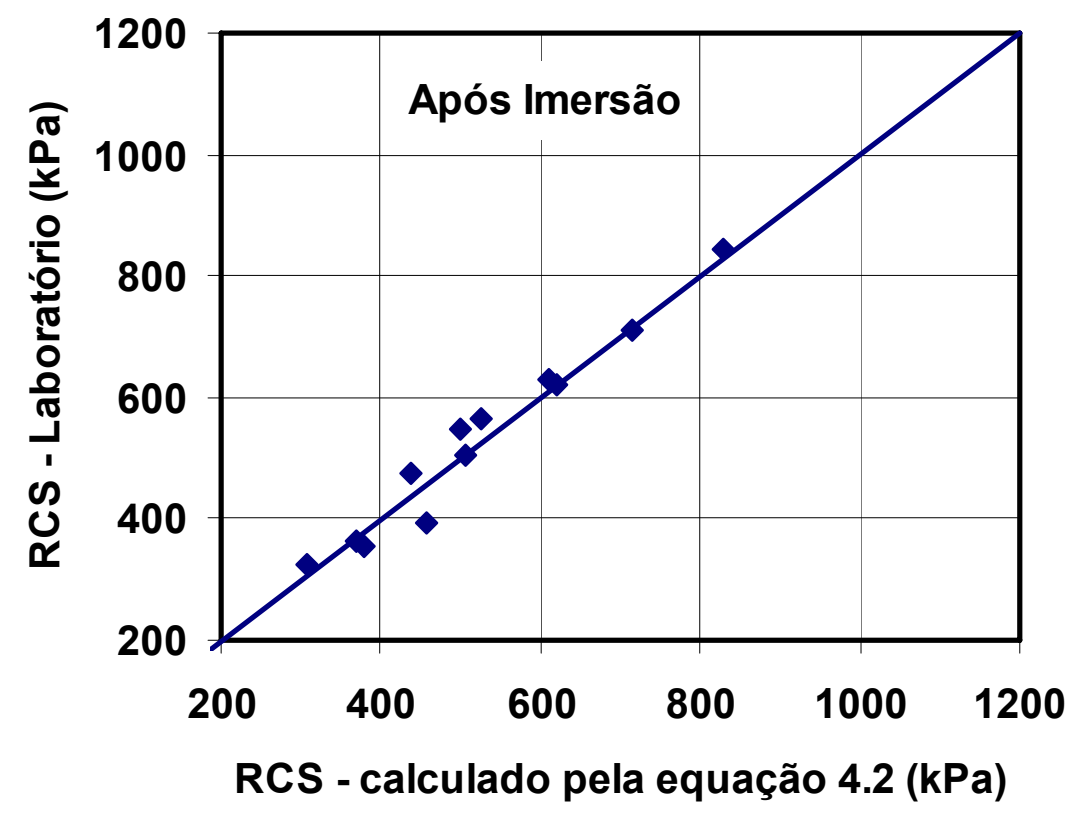

FIGURA 4.13 - Valores de RCS: equação 4.2 "versus" laboratório 
As Figuras 4.14 e 4.15 ilustram os modelos representados pelas Equações 4.1 e 4.2, respectivamente.

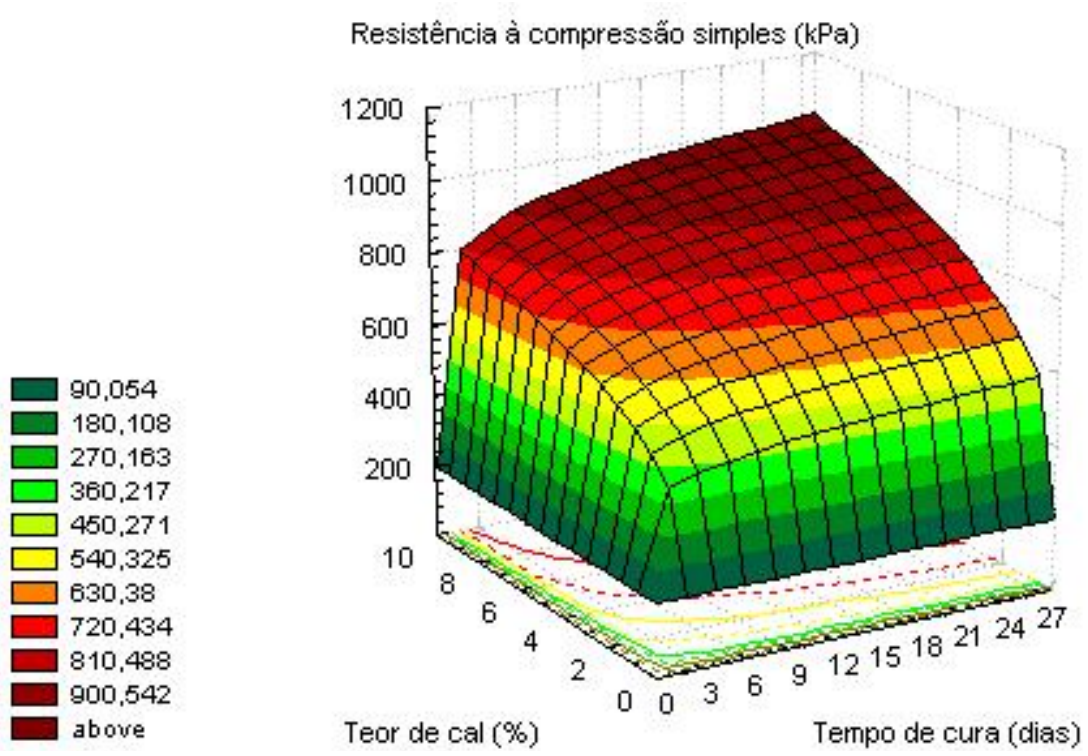

FIGURA 4.14 - Variação da resistência à compressão simples com o tempo de cura e teor de cal - sem imersão

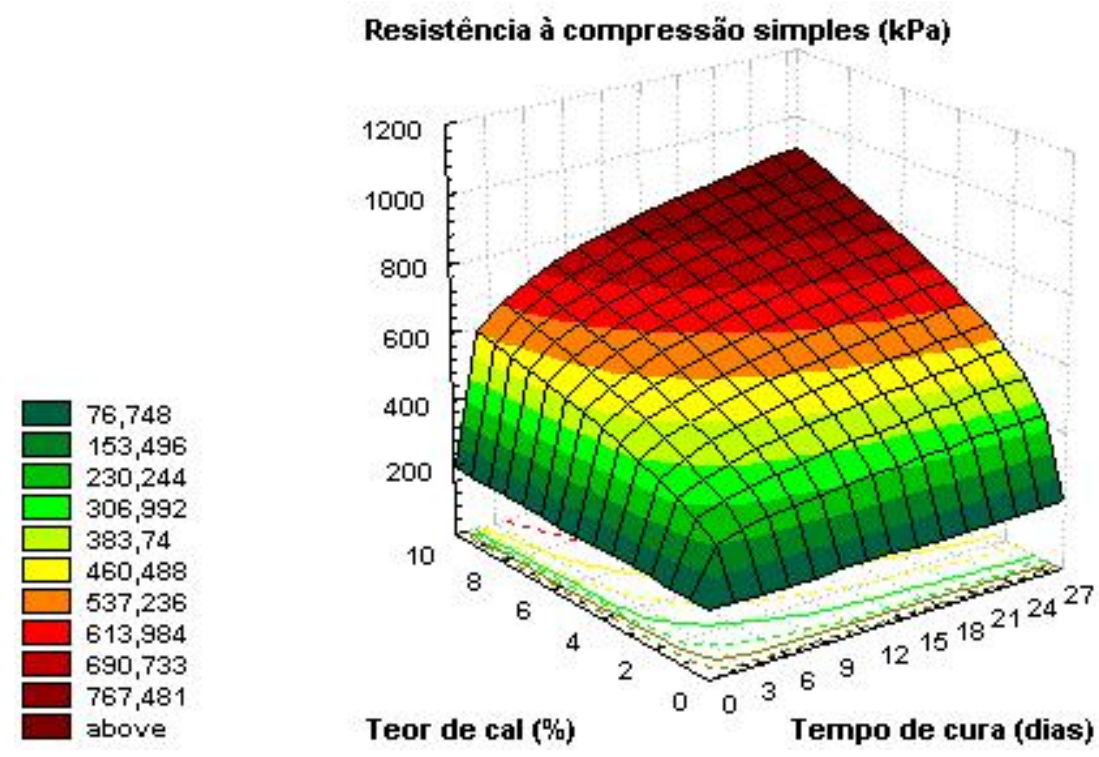

FIGURA 4.15 - Variação da resistência à compressão simples com o tempo de cura e teor de cal - após imersão

Fez-se ainda um estudo de variância, verificando o nível de significância da influência da imersão em água, do tempo de cura e do teor de cal, incluindo as interações entre esses fatores, nos resultados de RCS. O nível de confiança 
considerado foi de $95 \%$ e os resultados detalhados da análise são apresentados no Anexo F.

$\mathrm{Na}$ Tabela 4.5 são listados os resultados das análises feitas. Estas análises estão baseadas no teste $F$ de Snedecor (GARCIA-DIAZ \& PHILLIPS, 1995). Com base neste teste, uma hipótese é considerada significativa quando

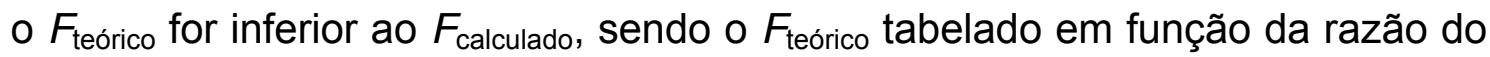
grau de liberdade do erro.

As fontes de variação ou tratamentos $A, B, C, A B, A C, B C$ e $A B C$ apresentados na Tabela 4.5 são enumerados em seguida:

- A: da variação da condição do ensaio (sem imersão e com imersão);

- B: do tempo de cura;

- C: do teor de cal $(0 \%, 3 \%, 5 \%, 7 \%$ e $10 \%)$

- $\mathrm{AB}$ : da condição de ensaio em conjunto com o tempo de cura;

- AC: da condição do ensaio em conjunto com o teor de cal e;

- BC: do tempo de cura em conjunto com o teor de cal;

- $\mathrm{ABC}$ : da condição do ensaio em conjunto com o tempo de cura e o teor de cal.

TABELA 4.5 - Influência das variáveis do estudo sobre os resultados de RCS

\begin{tabular}{|c|c|c|c|c|c|c|}
\hline $\begin{array}{c}\text { Fonte } \\
\text { de } \\
\text { Varia- } \\
\text { ção }\end{array}$ & $\begin{array}{c}\text { Graus } \\
\text { de } \\
\text { liberda- } \\
\text { de } \\
\text { (GL) }\end{array}$ & $\begin{array}{c}\text { Soma dos } \\
\text { quadrados } \\
\text { (SQ) }\end{array}$ & $\begin{array}{c}\text { Quadrado } \\
\text { médio } \\
\text { QM=SQ/GL }\end{array}$ & $\mathbf{F}_{\text {calculado }}$ & $F_{\text {teórico }}$ & significativo? \\
\hline$A$ & 1 & 4634546 & 4634546 & 3202,67 & 3,84 & Sim \\
\hline$B$ & 3 & 3156055 & 1052018 & 726,99 & 2,60 & Sim \\
\hline C & 4 & 2702862 & 675715 & 466,95 & 2,37 & Sim \\
\hline$A B$ & 3 & 591255 & 197085 & 136,19 & 2,60 & Sim \\
\hline$A C$ & 4 & 411899 & 102975 & 71,16 & 2,37 & Sim \\
\hline$B C$ & 12 & 723783 & 60315 & 41,68 & 1,75 & Sim \\
\hline$A B C$ & 12 & 295368 & 24614 & 17,01 & 1,75 & Sim \\
\hline Erro & 120 & 173651 & 1447 & & & \\
\hline Total & 159 & 1.939 .356 & 55.410 & & & \\
\hline
\end{tabular}

A Tabela 4.5 mostra que o teor de cal, o tempo de cura e a condição de ensaio e as interações entre estas variáveis influenciam de maneira 
significativa os resultados da resistência à compressão simples determinados nos ensaios.

\subsubsection{Deformabilidade (Rigidez), das misturas de fosfogesso e cal a partir dos ensaios de compressão simples}

Quando se estuda o comportamento mecânico de um material visando à construção de bases e sub-bases de pavimentos, a deformabilidade possui maior influência no seu desempenho em campo do que a tensão de ruptura determinada sob carregamento estático. O estudo da deformabilidade das misturas de fosfogesso e cal foi realizado através da análise da variação dos módulos tangentes iniciais $\left(\mathrm{E}_{0}\right)$ determinados a partir da curva tensão "versus" deformação resultantes dos ensaios de compressão simples.

Conforme os estudos de Ruiz (1964) e Drumm et al. (1990), o $\mathrm{E}_{0}$ é um índice representativo da deformabilidade das misturas e de interesse no estudo de pavimentos, pois guarda estreita relação com o módulo de resiliência. Para o cálculo de $E_{0}$, adotou-se o procedimento proposto por Duncan e Chang (1970), que aproxima a curva 'tensão versus deformação' a uma hipérbole.

O Anexo B apresenta os valores de deformabilidade de cada corpo-deprova ensaiado e o Anexo E, as correspondentes médias obtidas segundo o método estatístico de GRUBBS aplicado às réplicas ensaiadas.

A Tabela 4.6 apresenta os valores do módulo tangente inicial das misturas de fosfogesso e cal, para os teores de cal, tempo de cura e condições de ensaios considerados na pesquisa. Nesta tabela são também apresentados o aumento ou diminuição da rigidez, respectivamente com a adição da cal ou a imersão em água, e as correspondentes porcentagens de ganho ou perda determinadas em relação à deformabilidade do fosfogesso puro e a de corposde-prova ensaiados sem imersão.

Com base nos valores estimados, a deformabilidade das misturas de fosfogesso e cal representada pelo $E_{0}$ mostra um padrão de variação bastante semelhante ao padrão de variação determinado para a resistência à compressão simples, conforme apresentado nos subitens 4.3.1.1, 4.3.1.2, 4.3.1.3. 
TABELA 4.6 - Módulo tangente inicial e sua variação

\begin{tabular}{|c|c|c|c|c|c|c|c|}
\hline & & \multicolumn{3}{|c|}{ Sem imersão } & \multicolumn{3}{|c|}{ Após imersão } \\
\hline $\begin{array}{c}\text { Tempo } \\
\text { de } \\
\text { cura } \\
\text { (dias) }\end{array}$ & $\begin{array}{c}\text { Teor } \\
\text { de } \\
\text { cal } \\
(\%)\end{array}$ & $\begin{array}{c}E_{0} \\
(\mathrm{MPa})\end{array}$ & $\begin{array}{l}\text { Diferença } \\
E_{0}(\mathrm{MPa})\end{array}$ & $\begin{array}{l}\text { Ganho } \\
E_{0}(\%)\end{array}$ & $\begin{array}{c}E_{0} \\
(\mathrm{MPa})\end{array}$ & $\begin{array}{l}\text { Diferença } \\
\mathrm{E}_{0}(\mathrm{MPa})\end{array}$ & $\begin{array}{c}\text { Perda } \\
\text { por } \\
\text { imersão } \\
E_{0}(\%)\end{array}$ \\
\hline \multirow{5}{*}{0} & 0 & 17 & & & *nd & & \\
\hline & 3 & 19,5 & 2,5 & 15 & nd & nd & nd \\
\hline & 5 & 20 & 3 & 18 & nd & nd & nd \\
\hline & 7 & 21 & 4 & 24 & nd & nd & nd \\
\hline & 10 & 23 & 6 & 35 & nd & nd & nd \\
\hline \multirow{5}{*}{3} & 0 & 38 & & & nd & & \\
\hline & 3 & 54 & 16 & 42 & 31 & 23 & 43 \\
\hline & 5 & 57 & 19 & 50 & 33 & 24 & 42 \\
\hline & 7 & 63 & 25 & 66 & 43 & 20 & 32 \\
\hline & 10 & 67 & 29 & 76 & 54 & 13 & 19 \\
\hline \multirow{5}{*}{7} & 0 & 56,5 & & & nd & & \\
\hline & 3 & 72 & 15,5 & 27 & 35 & 37 & 51 \\
\hline & 5 & 81 & 24,5 & 43 & 38 & 43 & 53 \\
\hline & 7 & 89 & 32,5 & 58 & 59 & 30 & 34 \\
\hline & 10 & 93 & 36,5 & 65 & 82 & 11 & 12 \\
\hline \multirow{5}{*}{28} & 0 & 41 & & & nd & & \\
\hline & 3 & 101 & 60 & 146 & 83 & 18 & 18 \\
\hline & 5 & 106 & 65 & 159 & 94 & 12 & 11 \\
\hline & 7 & 123 & 82 & 200 & 104 & 19 & 15 \\
\hline & 10 & 156 & 115 & 280 & 129 & 27 & 17 \\
\hline
\end{tabular}

${ }^{*}$ nd - não determinado

\subsubsection{Influência do teor de cal}

As Figuras 4.16 e 4.17 ilustram a variação do módulo tangente inicial com o teor de cal, para os ensaios realizados sem imersão e após imersão prévia em água, respectivamente. Complementarmente, as Figuras $4.18 \mathrm{e}$ 4.19 apresentam estas mesmas variáveis através de diagrama de barras. 


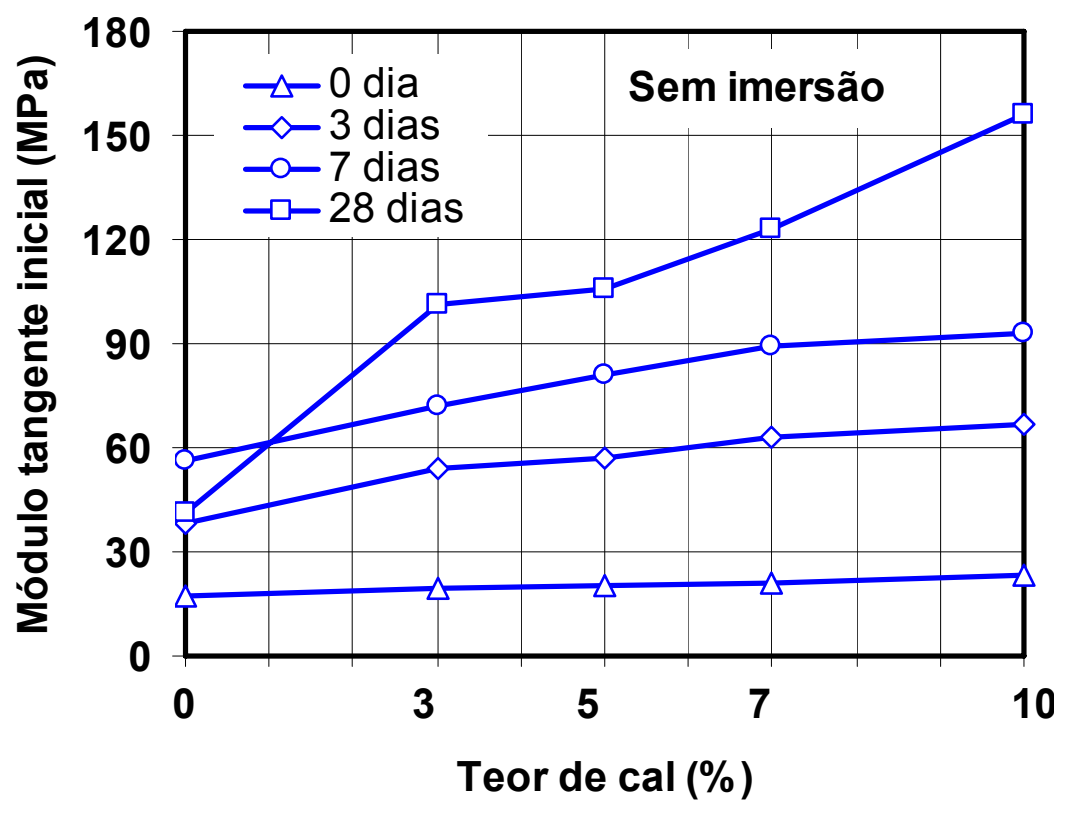

FIGURA 4.16 - variação do módulo tangente inicial para misturas de fosfogesso e cal ensaiadas sem imersão

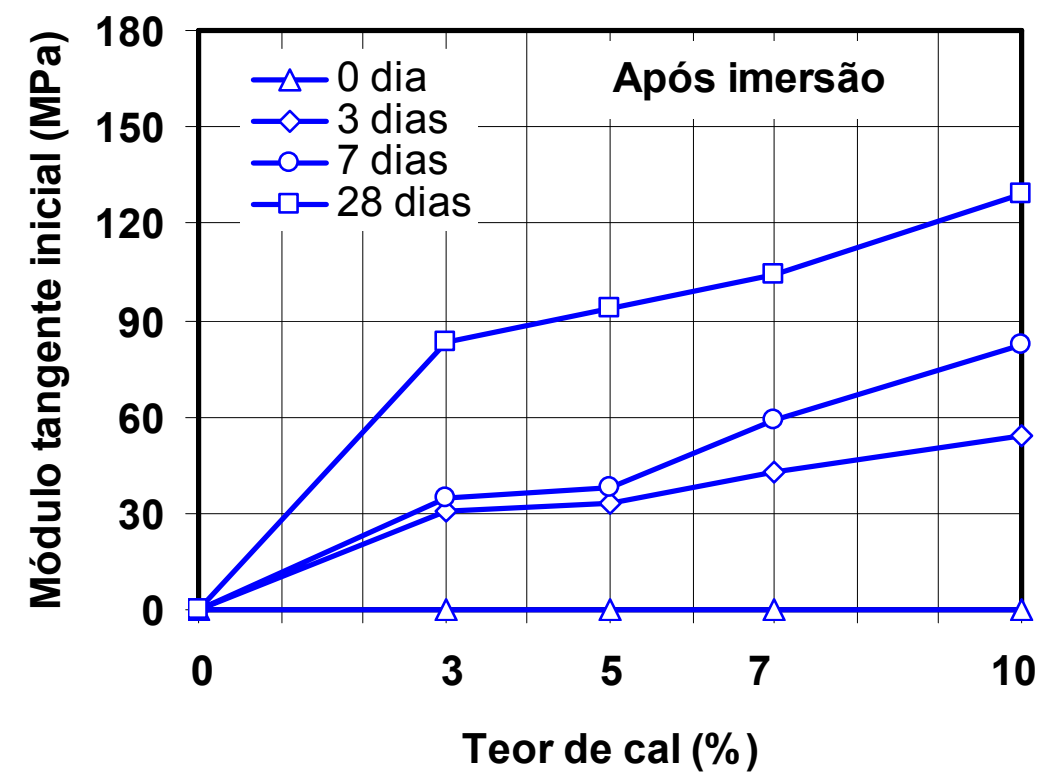

FIGURA 4.17 - Variação do módulo tangente inicial para misturas de fosfogesso e cal ensaiadas após imersão 


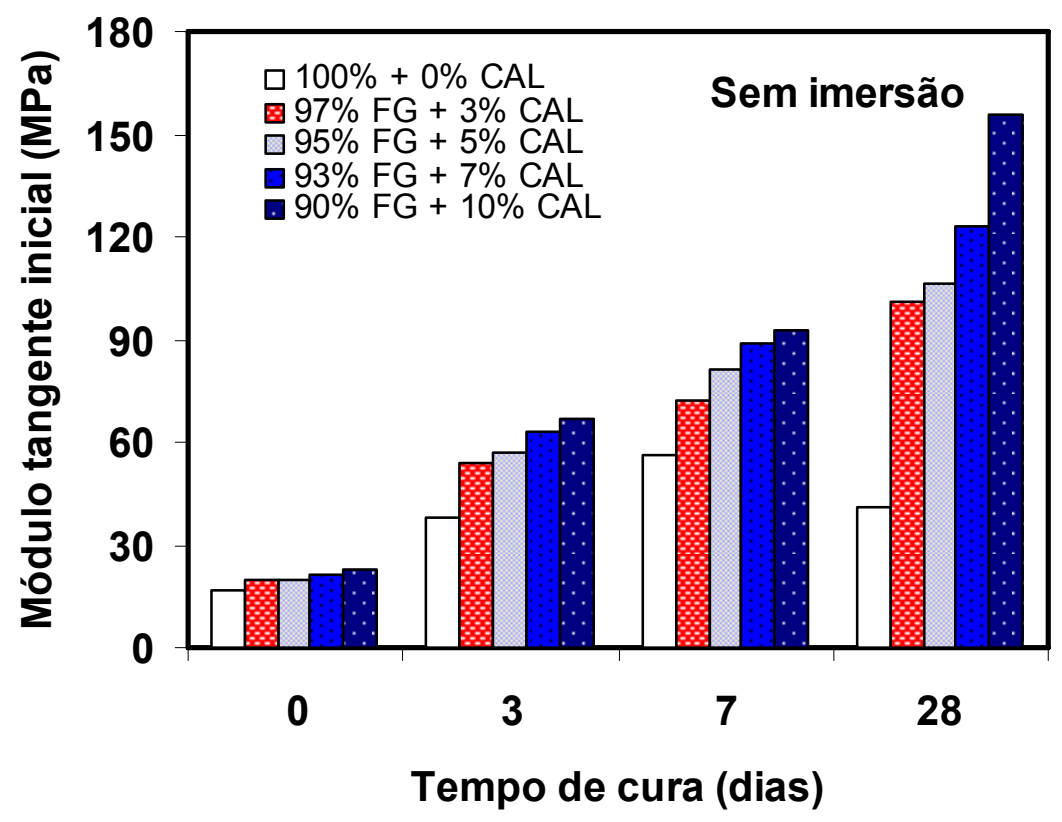

FIGURA 4.18 - Diagrama de barras - variação do módulo tangente inicial $\left(E_{0}\right)$ para misturas de fosfogesso e cal ensaiadas sem imersão

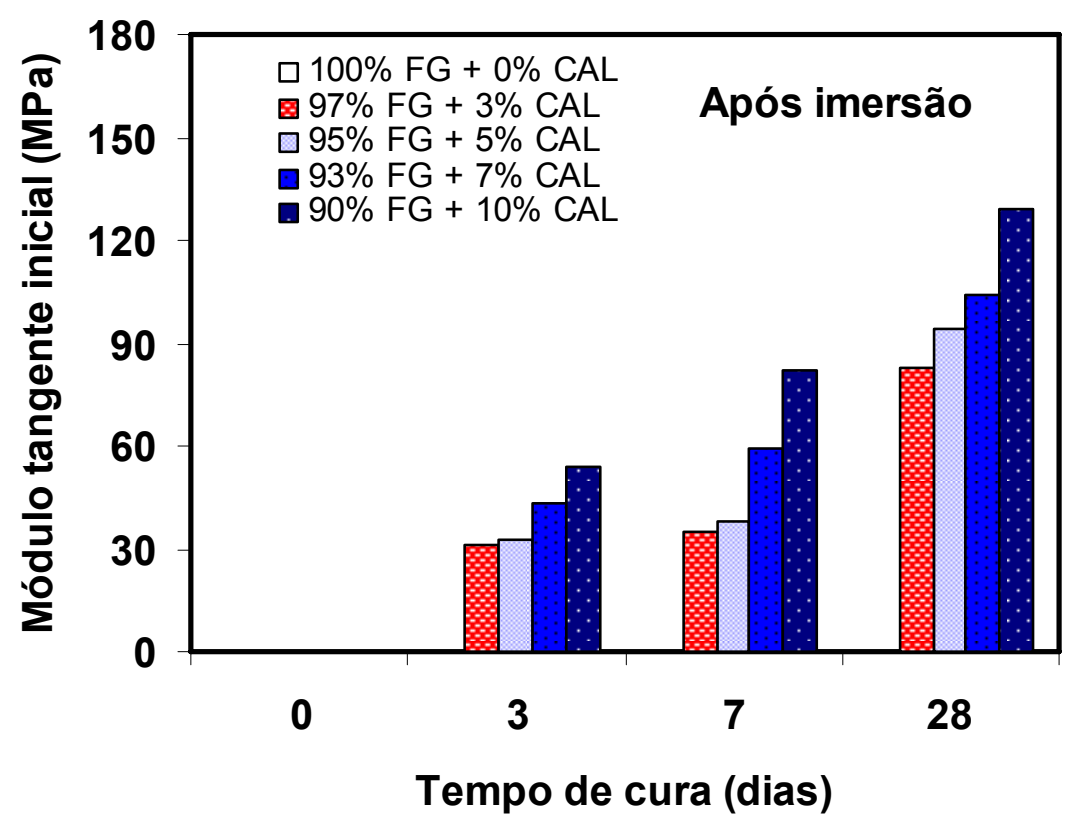

FIGURA 4.19 - Diagrama de barras - variação do módulo tangente inicial $\left(E_{0}\right)$ para misturas de fosfogesso e cal ensaiadas após imersão

Analisando-se os valores apresentados na Tabela 4.6 e as Figuras 4.16, 4.17, 4.18 e 4.19, observa-se que a adição de cal conduz ao aumento da rigidez $\left(E_{0}\right)$, à exceção das misturas não curadas e ensaiadas sem e após imersão em água. Levando-se em consideração os ensaios realizados sem imersão conforme ilustrado nas Figuras 4.16 e 4.18 e considerando-se valores 
médios calculados a partir dos resultados correspondentes a 3, 7 e 28 dias de cura, o ganho de rigidez em relação ao fosfogesso puro é de $72 \%, 84 \%, 108 \%$ e $140 \%$, respectivamente para os teores de 3\%, 5\%, $7 \%$ e $10 \%$ de cal. Para as mesmas condições de análise, o ganho de rigidez com a adição de cal é, na média, 3,3 vezes maior que o ganho de resistência.

Para os ensaios realizados após imersão em água, e conforme ilustrado nas Figuras 4.17 e 4.19, observa-se que o efeito positivo da adição de cal, como já destacado anteriormente para a resistência, é ainda mais evidente, visto que a totalidade dos corpos de prova constituídos apenas por fosfogesso, desintegrarem-se para todos os tempos de cura, não permitindo a execução dos ensaios. Quando se analisa a ação da água sobre o fosfogesso estabilizado, e considerando-se valores médios calculados a partir dos tempos de cura de 3,7 e 28 dias, a redução do valor de $E_{0}$ é de $37 \%, 35 \%, 27 \%$ e $16 \%$, para os teores de cal de $3 \%, 5 \%, 7 \%$ e $10 \%$ de cal, respectivamente. Neste caso, o efeito da água na redução da rigidez é equivalente, na média, ao observado para a resistência.

Os diagramas das Figuras 4.18 e 4.19 ilustram que o efeito positivo da cal torna-se realmente significativo a partir de 3 dias de cura onde o acréscimo do valor de $E_{0}$ mantém-se praticamente constante. Observa-se ainda que, para todos os teores de cal e para as duas condições de ensaio, as maiores deformabilidades são alcançadas aos 28 dias.

Para a comparação entre os efeitos da adição da cal e do cimento ao fosfogesso, a Tabela 4.7 apresenta valores de $E_{0}$ determinados nesta pesquisa e por Silvestre (2002) para misturas de fosfogesso estabilizado com 5\% e 10\% do cimento CP II-E 32, ensaiadas sem imersão e após imersão em água.

TABELA 4.7 - Módulo tangente inicial de misturas de fosfogesso e cal, e fosfogesso e cimento

\begin{tabular}{|c|c|c|c|c|c|c|}
\hline & \multicolumn{4}{|c|}{ Módulo tangente inicial (MPa) } & \multirow{2}{*}{\multicolumn{2}{|c|}{$\begin{array}{l}\text { Perda de rigidez } \\
\text { Por imersão }\end{array}$}} \\
\hline & \multicolumn{2}{|c|}{ Sem imersão } & \multicolumn{2}{|c|}{ Após imersão } & & \\
\hline & 7 dias & 28 dias & 7 dias & 28 dias & 7 dias (\%) & 28 dias (\%) \\
\hline $5 \%$ de cal & 81 & 106 & 38 & 94 & 53 & 11 \\
\hline $5 \%$ de cimento & 213 & 384 & 155 & 345 & 27 & 10 \\
\hline $10 \%$ de cal & 93 & 156 & 82 & 129 & 12 & 17 \\
\hline $10 \%$ de cimento & 311 & 404 & 284 & 385 & 9 & 5 \\
\hline
\end{tabular}


Analisando-se os valores apresentados na Tabela 4.7, observa-se que, todas as misturas de fosfogesso e cimento apresentaram maiores rigidez, consideradas as mesmas condições de ensaio, que as misturas de fosfogesso e cal. Comparando-se os valores médios calculados a partir dos valores de $\mathrm{E}_{0}$ correspondentes a todas as condições ensaiadas, as misturas estabilizadas com cal apresentam rigidez $218 \%$ inferior à das misturas estabilizadas com cimento.

\subsubsection{Influência do tempo de cura}

O tempo de cura é um fator importante no desenvolvimento da rigidez de misturas estabilizadas com cal. As Figuras 4.20 e 4.21 ilustram, respectivamente, a variação do módulo tangente inicial $\left(E_{0}\right)$, com o tempo de cura, para os corpos-de-provas ensaiados sem imersão e após imersão prévia em água. Complementarmente, as Figuras 4.22 e 4.23 apresentam estas mesmas variáveis através de diagrama de barras.

Analisando-se os valores da Tabela 4.6 e as Figuras 4.20, 4.21, 4.22 e 4.23, observa-se que o acréscimo do tempo de cura conduz ao aumento da rigidez $\left(E_{0}\right)$ para todos os teores de cal e para as duas condições de ensaio, semelhante ao já observado para os valores de RCS.

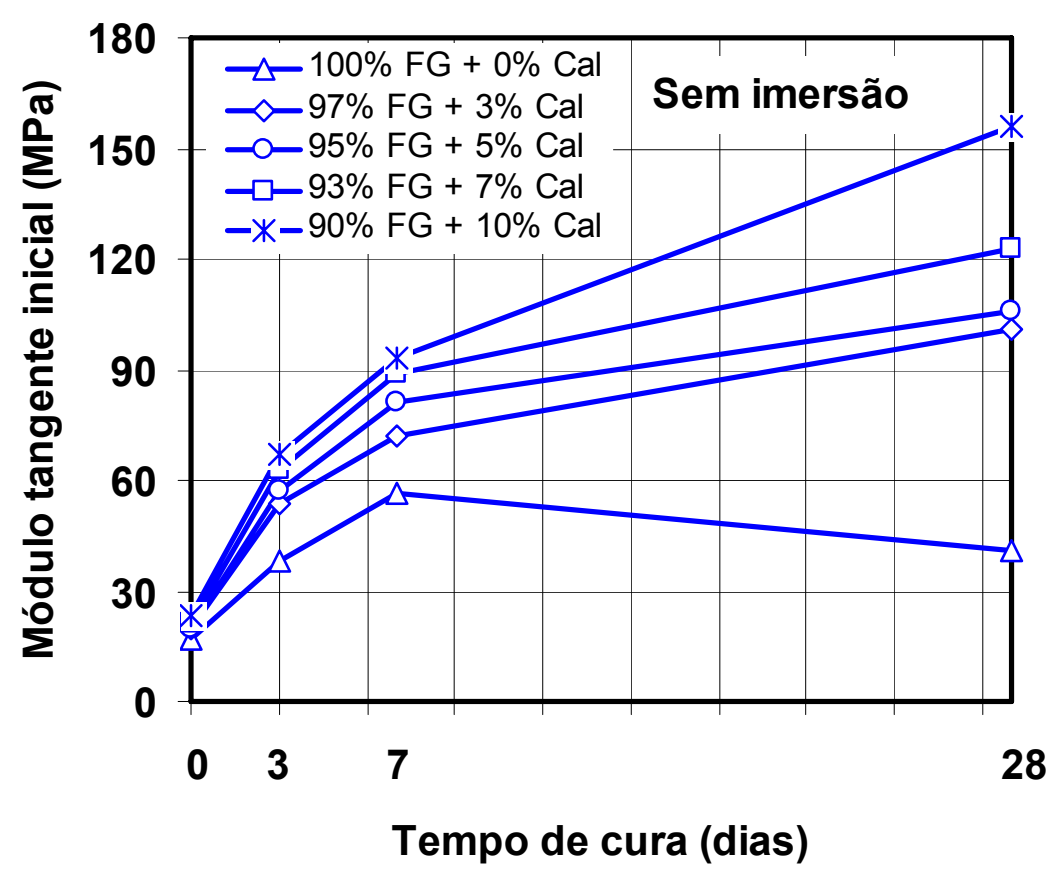

FIGURA 4.20 - Variação do módulo tangente inicial para misturas de fosfogesso e cal ensaiadas sem imersão 


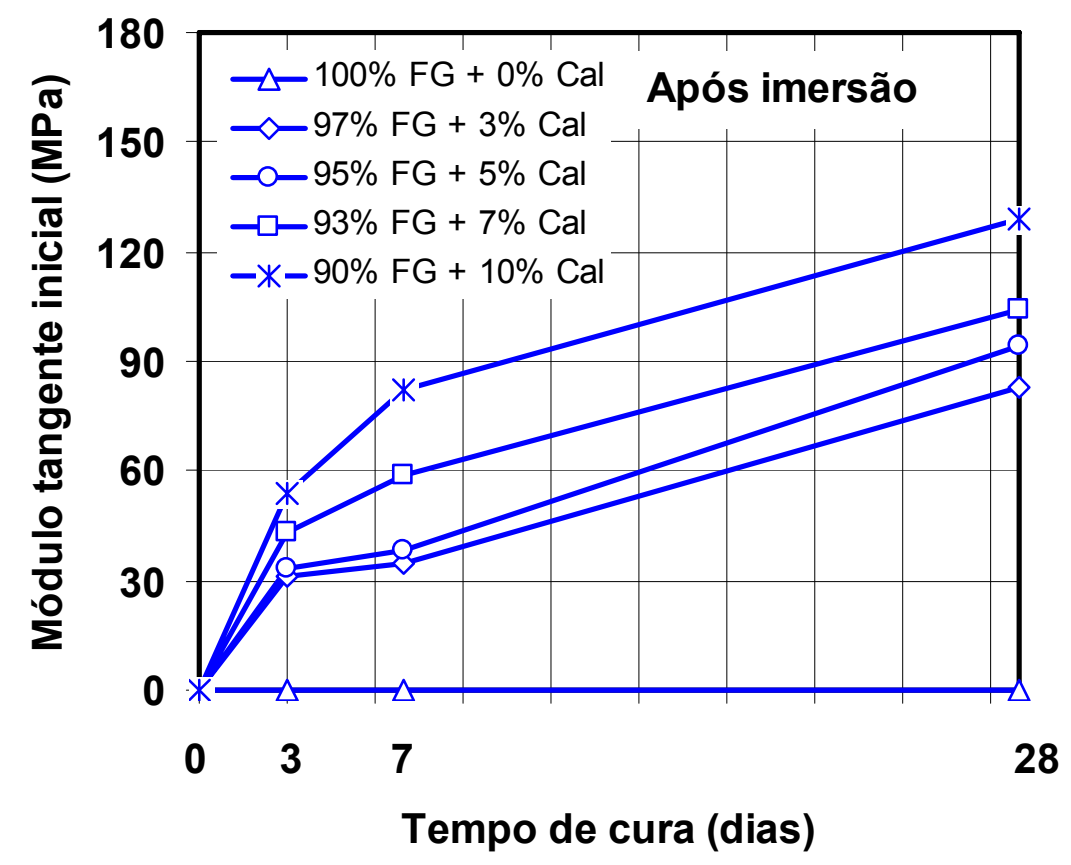

FIGURA 4.21 - Variação do módulo tangente inicial para misturas de fosfogesso e cal ensaiadas após imersão

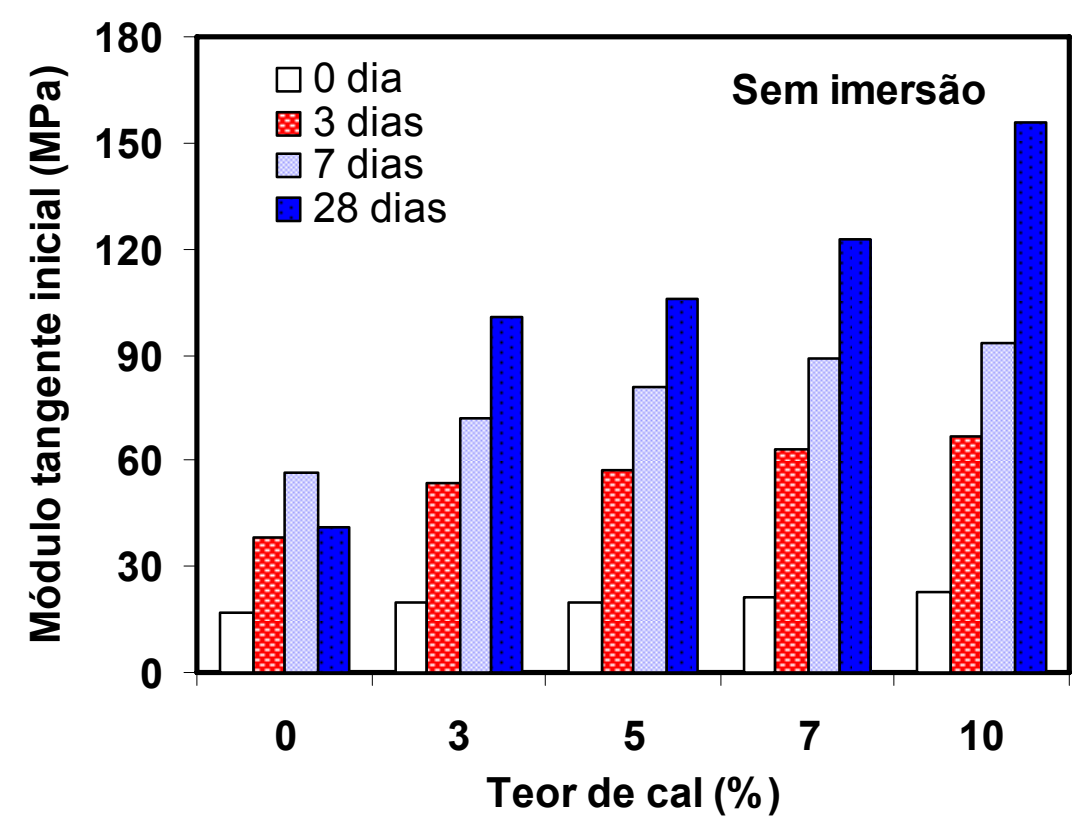

FIGURA 4.22 - Diagrama de barras - variação do módulo tangente inicial para misturas de fosfogesso e cal ensaiadas sem imersão 


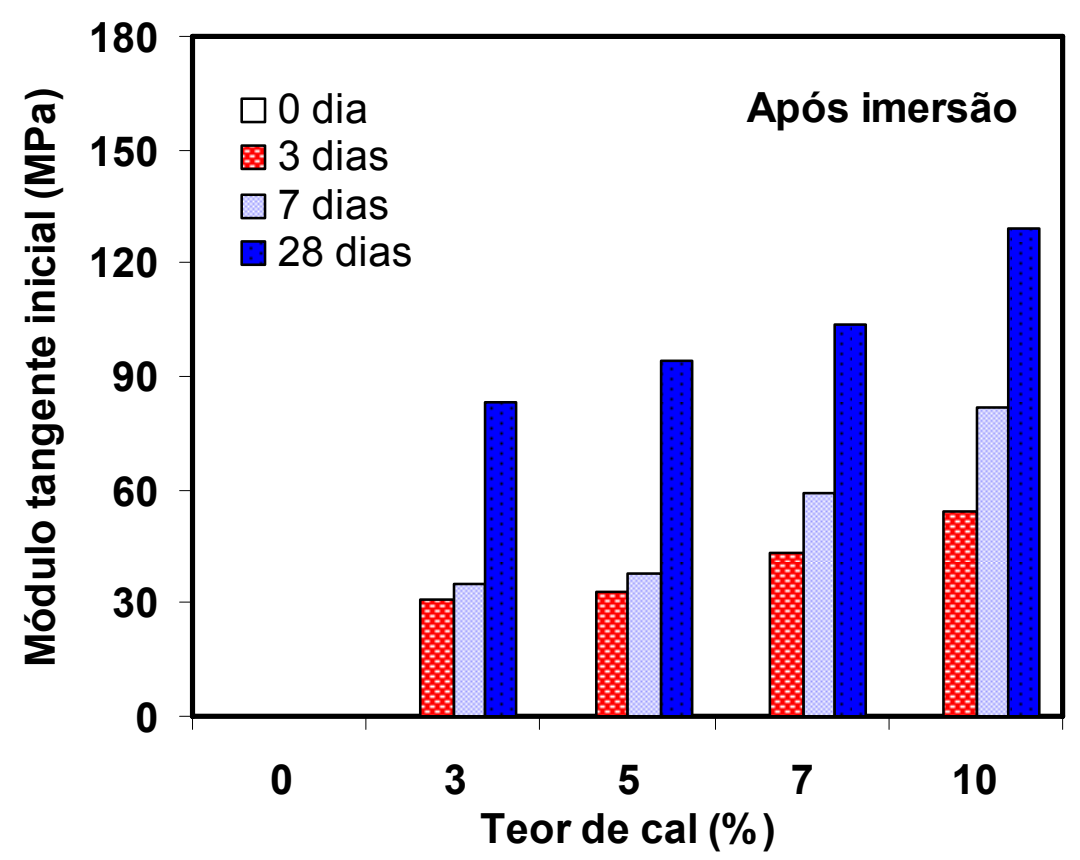

FIGURA 4.23 - Diagrama de barras - variação do módulo tangente inicial para misturas de fosfogesso e cal ensaiadas após imersão

Para os ensaios realizados sem imersão, vide Figuras 4.20 e 4.22, e considerando-se valores médios calculados a partir dos resultados correspondentes a todos os teores de cal, excetuando o fosfogesso puro, observa-se que o ganho dos valores do módulo tangente inicial $\left(E_{0}\right)$, em relação às amostras ensaiadas sem cura é de $189 \%, 301 \%$ e $482 \%$, para os tempos de cura 3, 7 e 28 dias, respectivamente. Para as mesmas condições de análise, o efeito da cura no aumento da rigidez é, na média, 4 vezes maior que o observado para a resistência à compressão simples.

Para os ensaios realizados após imersão em água, vide Figuras 4.21 e 4.23, a importância da cura torna-se ainda mais evidente, pois todos os corpos de prova não curados desintegraram-se durante o processo. Nestas condições e considerando-se valores médios calculados a partir dos resultados correspondentes a todos os teores de cal, o ganho de rigidez nos períodos de 3 a 7 dias, e de 3 a 28 dias, é de $33 \%$ e 130\%, respectivamente. Neste caso, o efeito da cura no aumento da rigidez é, na média, 2 vezes maior que o observado para a resistência à compressão simples.

Portanto, igualmente ao já destacado para a resistência, não se observou efeito positivo da cal em corpos-de-prova ensaiados imediatamente 
após a compactação, indicando que a ação do aditivo a curto prazo (troca cátion-iônica) não se processa, restando apenas o efeito de cimentação (reação pozolânica da cal com o resíduo), que se dá a longo prazo.

Comparando-se os valores de rigidez obtidos nesta pesquisa, com os valores determinados por Silvestre (2002), para misturas de fosfogesso e cimento, conforme apresentado na Tabela 4.7, observa-se que o efeito do tempo de cura é mais marcante para esta última mistura do que para as misturas estabilizadas com cal.

\subsubsection{Relação entre $E_{0}$, o tempo de cura e o teor de cal}

Foram realizadas regressões múltiplas, utilizando-se o módulo tangente inicial $\left(E_{0}\right)$ como variável dependente e o tempo de cura (TC) e o teor de cal (\%) como variáveis independentes. Assim, determinaram-se as Equações 4.3 e 4.4 considerando-se, respectivamente, os resultados das misturas ensaiadas, sem imersão e com imersão previam em água.

$$
\begin{array}{ll}
\mathrm{E}_{0}=25,50 \cdot(\mathrm{TC})^{0,30} \cdot(\mathrm{cal})^{0,31} & \mathrm{R}^{2}=0,96 \\
\mathrm{E}_{0}=10,38 \cdot(\mathrm{TC})^{0,43} \cdot(\mathrm{cal})^{0,48} & \mathrm{R}^{2}=0,96
\end{array}
$$

onde:

$\mathrm{E}_{0}-$ módulo tangente inicial (MPa);

TC - tempo de cura (dias);

(cal) - variação do teor de cal (\%).

Com estas equações apresentadas acima, pretendeu-se analisar se os valores obtidos de $E_{0}$ neste modelo proposto são equivalentes aos obtidos com os valores em laboratório. Vale salientar que foi excluído o tempo de cura de zero dias, bem como o teor de $0 \%$ de cal para este modelo proposto. A influência do teor de cal, tempo de cura e condição de ensaio foi festa pela análise de variância.

As Equações 4.3 e 4.4 apresentam coeficientes de determinação $\left(R^{2}\right)$ iguais a 0,96 e 0,96 , respectivamente. Os valores elevados de $R^{2}$ indicam que estas equações representam com fidelidade a relação entre as variáveis consideradas. Este fato também é evidenciado analisando-se as Figuras 4.24 e 4.25 que apresentam valores de $E_{0}$ calculados a partir das Equações 4.3 e 
4.4, respectivamente, e os valores correspondentes determinados nos ensaios de laboratório.

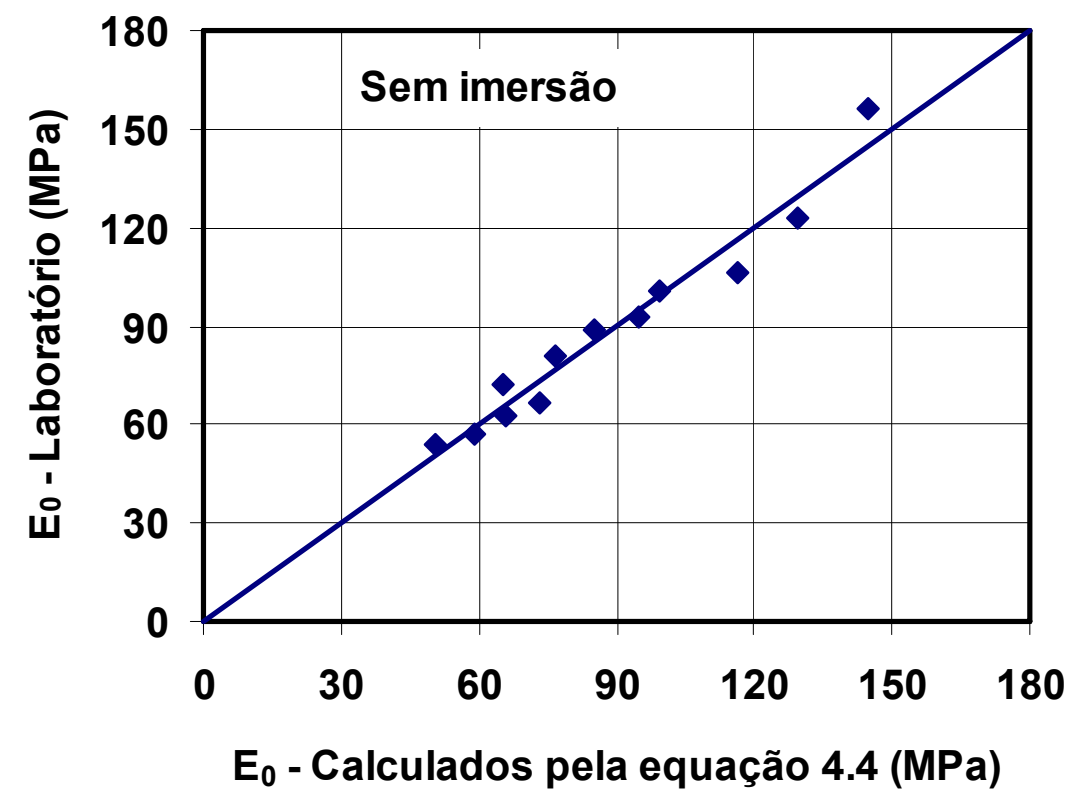

FIGURA 4.24 - Valores de $E_{0}$ : equação 4.3 “versus” laboratório

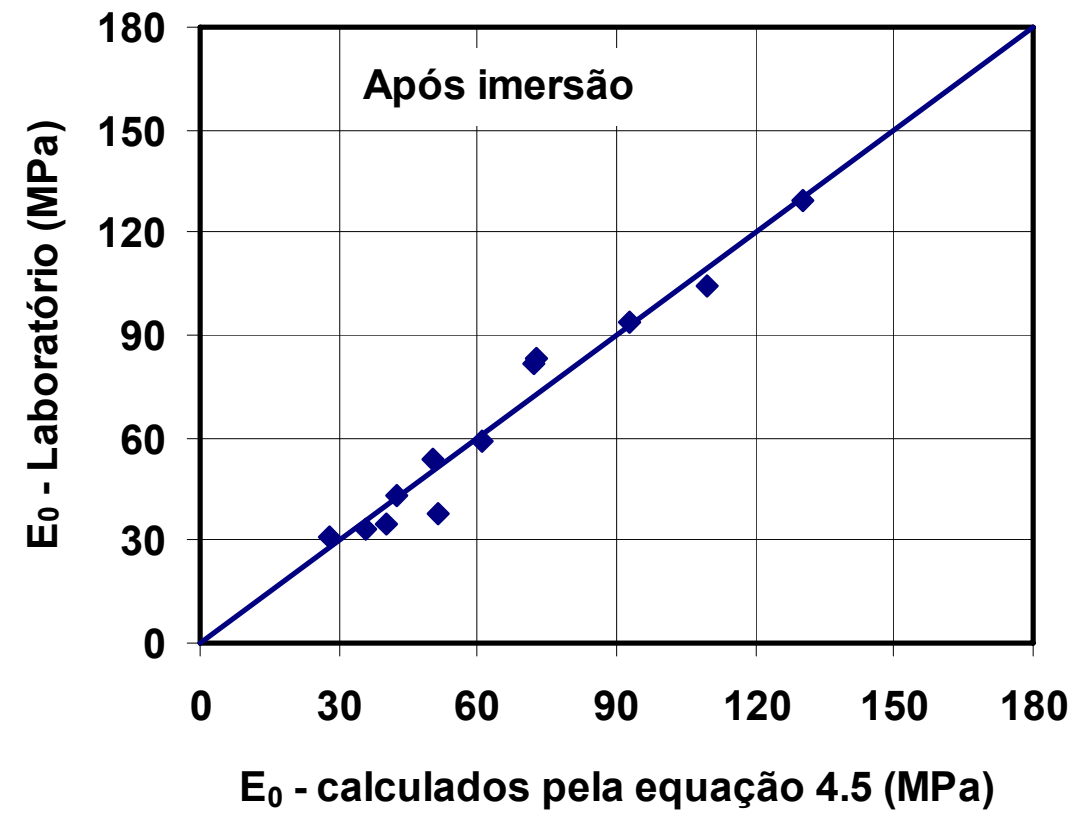

FIGURA 4.25 - Valores de $E_{0}$ : equação 4.4 “versus” laboratório

As Figuras 4.26 e 4.27 ilustram os modelos representados pelas Equações 4.3 e 4.4, respectivamente. 


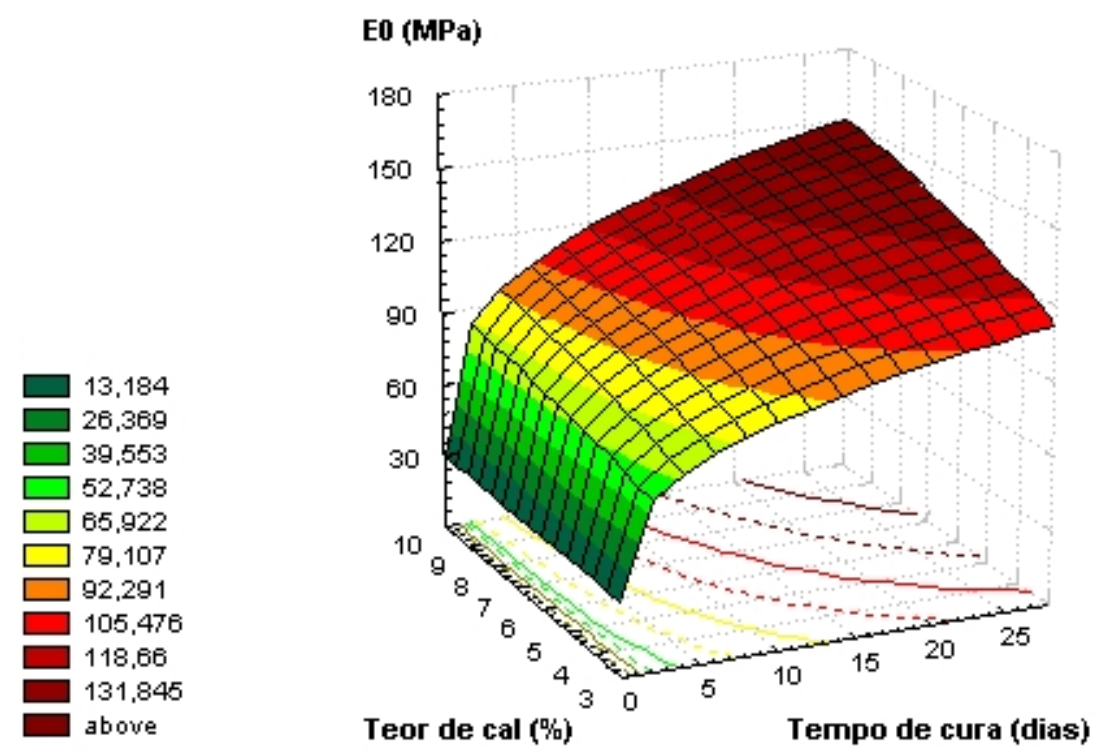

FIGURA 4.26 - Variação da deformabilidade com o tempo de cura e teor de cal - sem imersão

E0 (MPa)
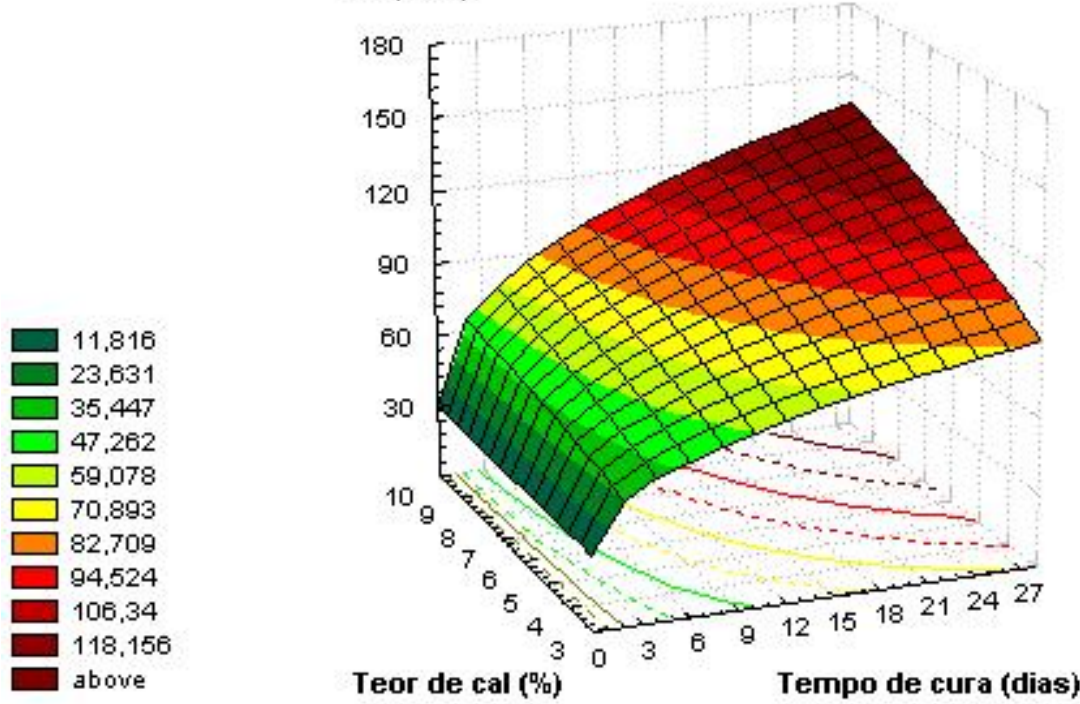

\section{FIGURA 4.27 - Variação da deformabilidade com o tempo de cura e teor de cal - após imersão}

Fez-se ainda um estudo de variância, verificando o nível de significância da influência da imersão em água, do tempo de cura e do teor de cal, incluindo as interações entre esses fatores, no resultados de $E_{0}$. O nível de confiança considerado foi de $95 \%$ e os resultados detalhados da análise são apresentados no Anexo F.

Na Tabela 4.8 são listados os resultados das análises feitas. Estas análises estão baseadas no teste $F$ de Snedecor (GARCIA-DIAZ \& PHILLIPS, 
1995). Com base neste teste, uma hipótese é considerada significativa quando o $F_{\text {teórico }}$ for inferior ao $F_{\text {calculado, sendo o }} F_{\text {teórico }}$ tabelado em funçào da razão do grau de liberdade do erro.

As fontes de variação ou tratamentos $A, B, C, A B, A C, B C$ e $A B C$ apresentados na Tabela 4.8 são enumeradas em seguida:

- A: da variação da condição do ensaio (sem imersão e com imersão);

- B:do tempo de cura;

- C: do teor de cal $(0 \%, 3 \%, 5 \%, 7 \%$ e $10 \%)$

- $A B$ : da condição de ensaio em conjunto com o tempo de cura;

- AC: da condição do ensaio em conjunto com o teor de cal e;

- BC: do tempo de cura em conjunto com o teor de cal;

- $A B C:$ da condição do ensaio em conjunto com o tempo de cura e com o teor de cal.

Tabela 4.8 - Influência das variáveis do estudo sobre os resultados do $\left(E_{0}\right)$

\begin{tabular}{cccrrrr}
$\begin{array}{c}\text { Fonte de } \\
\text { Variação }\end{array}$ & $\begin{array}{c}\text { Graus de } \\
\text { liberdade } \\
\text { (GL) }\end{array}$ & $\begin{array}{c}\text { Soma dos } \\
\text { quadrados } \\
\text { (SQ) }\end{array}$ & $\begin{array}{c}\text { Quadrado } \\
\text { médio } \\
\text { QM=SQ/GL }\end{array}$ & F $_{\text {calculado }}$ & $\mathbf{F}_{\text {teórico }}$ & significativo? \\
\hline A & 1 & $1,2523 \mathrm{E}+10$ & $1,2523 \mathrm{E}+10$ & 46,22 & 4,84 & $\mathrm{Sim}$ \\
$\mathrm{B}$ & 3 & $1,0361 \mathrm{E}+11$ & $3,4536 \mathrm{E}+10$ & 127,47 & 4,84 & $\mathrm{Sim}$ \\
$\mathrm{C}$ & 4 & $3,3407 \mathrm{E}+10$ & 835168237 & 6,63 & 3,98 & $\mathrm{Sim}$ \\
$\mathrm{AB}$ & 3 & 5385706847 & 1795235616 & 5,40 & 4,84 & $\mathrm{Sim}$ \\
$\mathrm{AC}$ & 4 & 5847046984 & 1461761746 & 7,46 & 3,98 & $\mathrm{Sim}$ \\
$\mathrm{BC}$ & 12 & $2,4249 \mathrm{E}+10$ & 2020747155 & 2,19 & 3,98 & Não \\
ABC & 12 & 7134309928 & 594525827 & & & \\
\cline { 1 - 4 } Erro & 120 & $3,2513 \mathrm{E}+10$ & 270938982 & & & \\
Total & 159 & $2,2467 \mathrm{E}+11$ & & & &
\end{tabular}

A Tabela 4.8 mostra que o teor de cal, o tempo de cura e a condição de ensaio $e$ as interações entre estas variáveis influenciam de maneira significativa os resultados da deformabilidade determinados nos ensaios. Ainda segundo a Tabela 4.8, pode-se observar que a interação entre o tempo de cura e o teor de cal mostrou-se não significativa. 


\subsubsection{Resistência à tração por compressão diametral}

As solicitações à tração nas camadas de misturas com cal influenciam no desempenho do pavimento. As elevadas resistência e rigidez que estas camadas podem apresentar induzem um comportamento de placa, que além de reduzir substancialmente as pressões transmitidas às camadas sub adjacentes, geram tensões de flexão consideráveis na própria camada estabilizada. Segundo Thomson (1969), essa condição controla o projeto estrutural das camadas de solos estabilizados com cal. Este aspecto justifica a determinação do comportamento à tração das misturas analisadas no presente estudo.

O ensaio de compressão diametral tem sido considerado como uma das melhores alternativas para se determinar a resistência à tração dos corpos-deprova de misturas estabilizadas (KENNEY \& HUDSON, 1968).

O Anexo $\mathbf{C}$ apresenta os valores de resistência à tração por compressão diametral de cada corpo-de-prova e o Anexo E, as correspondentes médias obtidas segundo o método estatístico de GRUBBS aplicado às réplicas ensaiadas.

A Tabela 4.9 apresenta a resistência à tração por compressão diametral (RCD), das misturas de fosfogesso e cal, para os teores de cal, tempo de cura e condições de ensaios considerados na pesquisa. Nesta tabela são também apresentados o aumento ou diminuição da resistência à tração por compressão diametral, respectivamente com a adição da cal ou a imersão em água, e as correspondentes porcentagens de ganho ou perda determinadas em relação à resistência do fosfogesso puro e a de corpos-de-prova ensaiados sem imersão. 
TABELA 4.9 - Resistência à tração por compressão diametral e a sua variação

\begin{tabular}{|c|c|c|c|c|c|c|c|}
\hline & & \multicolumn{3}{|c|}{ Sem imersão } & \multicolumn{3}{|c|}{ Após imersão } \\
\hline $\begin{array}{c}\text { Tempo } \\
\text { de } \\
\text { cura } \\
\text { (dias) }\end{array}$ & $\begin{array}{c}\text { Teor } \\
\text { de cal } \\
(\%)\end{array}$ & $\begin{array}{l}\text { RCD } \\
(\mathrm{kPa})\end{array}$ & $\begin{array}{l}\text { Diferença } \\
\text { RCD (kPa) }\end{array}$ & $\begin{array}{c}\text { Ganho } \\
\text { RCD } \\
(\%)\end{array}$ & $\begin{array}{l}\mathrm{RCD} \\
(\mathrm{kPa})\end{array}$ & $\begin{array}{l}\text { Diferença } \\
\text { RCD (kPa) }\end{array}$ & $\begin{array}{c}\text { Perda } \\
\text { por } \\
\text { imersão } \\
\text { RCD } \\
(\%)\end{array}$ \\
\hline \multirow{5}{*}{0} & 0 & 29 & & & *nd & & \\
\hline & 3 & 30 & 1 & 3 & nd & nd & nd \\
\hline & 5 & 34 & 5 & 17 & nd & nd & nd \\
\hline & 7 & 40 & 11 & 38 & nd & nd & nd \\
\hline & 10 & 46 & 17 & 59 & nd & nd & nd \\
\hline \multirow{5}{*}{3} & 0 & 40 & & & $\overline{\text { nd }}$ & & \\
\hline & 3 & 41 & 1 & 3 & 29 & 12 & 29 \\
\hline & 5 & 43 & 3 & 8 & 30 & 13 & 30 \\
\hline & 7 & 46 & 6 & 15 & 34 & 12 & 26 \\
\hline & 10 & 57 & 17 & 43 & 46 & 11 & 19 \\
\hline \multirow{5}{*}{7} & 0 & 41 & & & nd & & \\
\hline & 3 & 52 & 11 & 27 & 32 & 20 & 38 \\
\hline & 5 & 53 & 12 & 29 & 33 & 20 & 38 \\
\hline & 7 & 58 & 17 & 41 & 35 & 23 & 40 \\
\hline & 10 & 63 & 22 & 54 & 51 & 12 & 19 \\
\hline \multirow{5}{*}{28} & 0 & 52 & & & nd & & \\
\hline & 3 & 77 & 25 & 48 & 59 & 18 & 23 \\
\hline & 5 & 83 & 31 & 60 & 69 & 14 & 17 \\
\hline & 7 & 97 & 45 & 87 & 74 & 23 & 24 \\
\hline & 10 & 114 & 62 & 54 & 85 & 29 & 25 \\
\hline
\end{tabular}

${ }^{*}$ nd - não determinado

\subsubsection{Influência do teor de cal}

As Figuras 4.28 e 4.29 ilustram a variação da resistência à tração por compressão diametral com o teor de cal, para ensaios realizados sem imersão e após imersão prévia em água, respectivamente. Complementarmente as Figuras 4.30 e 4.31 apresentam essas mesmas variáveis através de diagrama de barras. 


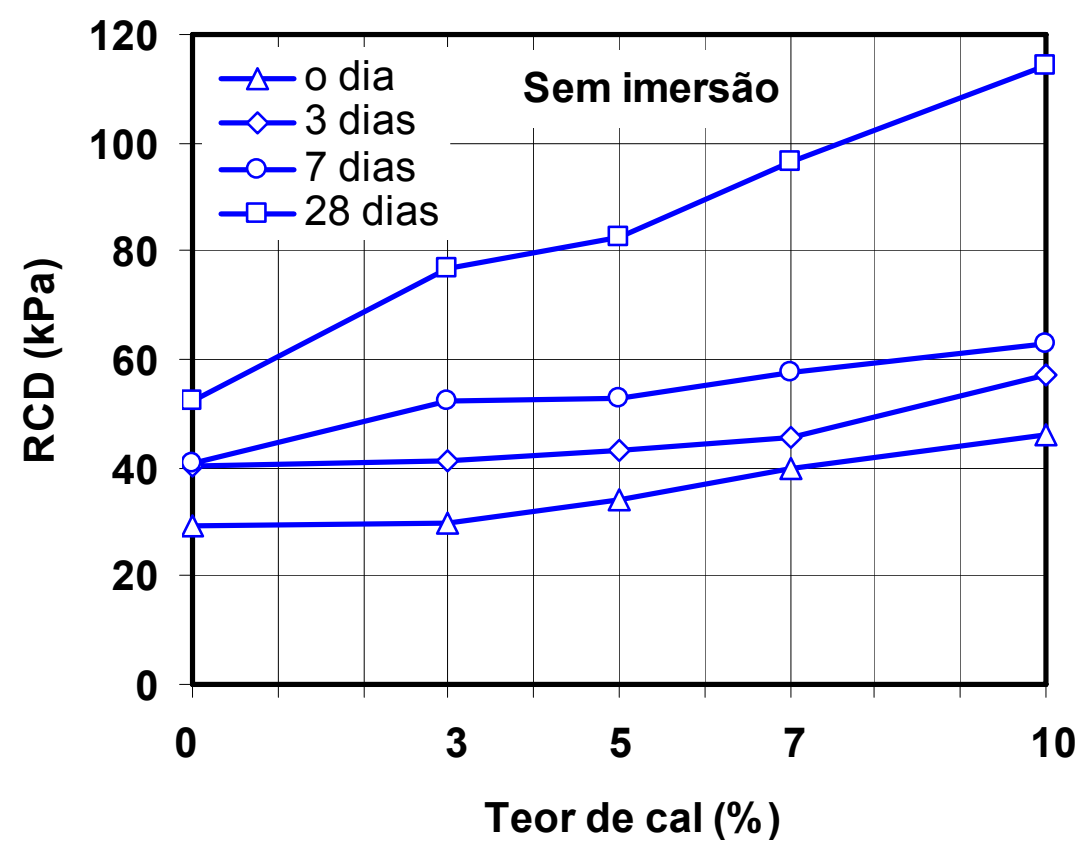

FIGURA 4.28 - Variação da resistência à tração por compressão diametral para misturas de fosfogesso e cal ensaiadas sem imersão

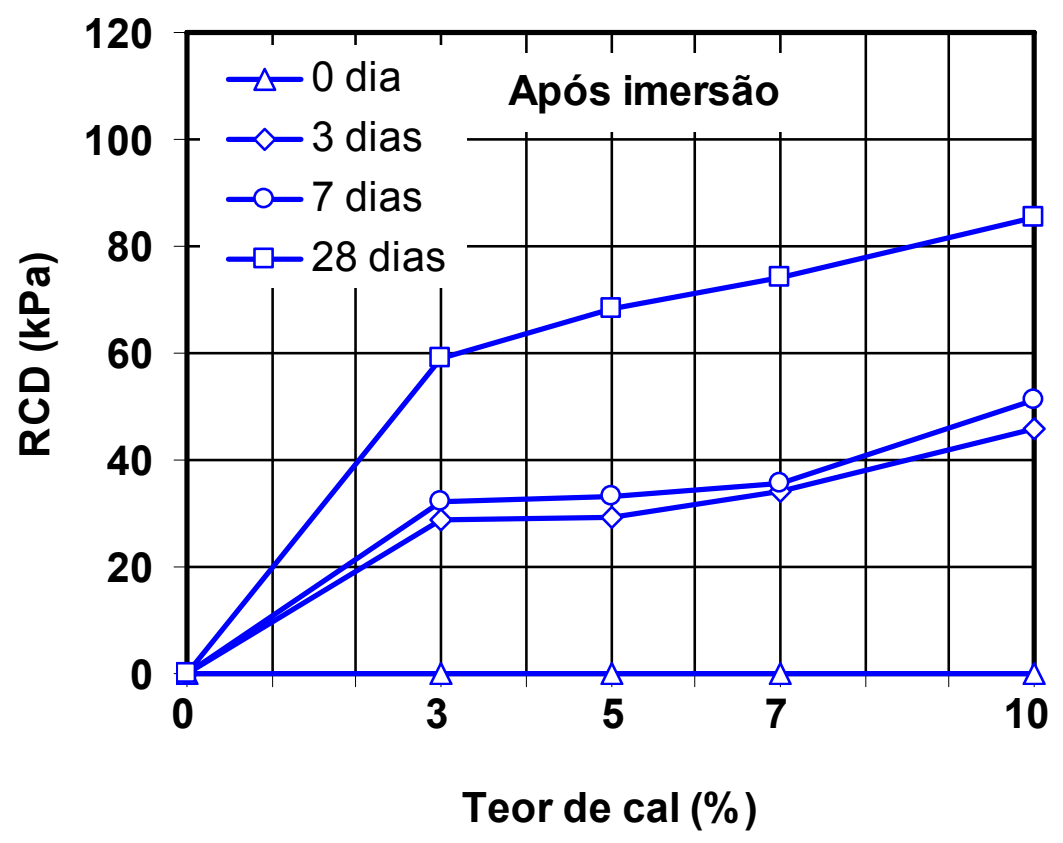

FIGURA 4.29 - Variação da resistência à tração por compressão diametral para misturas de fosfogesso e cal ensaiadas após imersão 


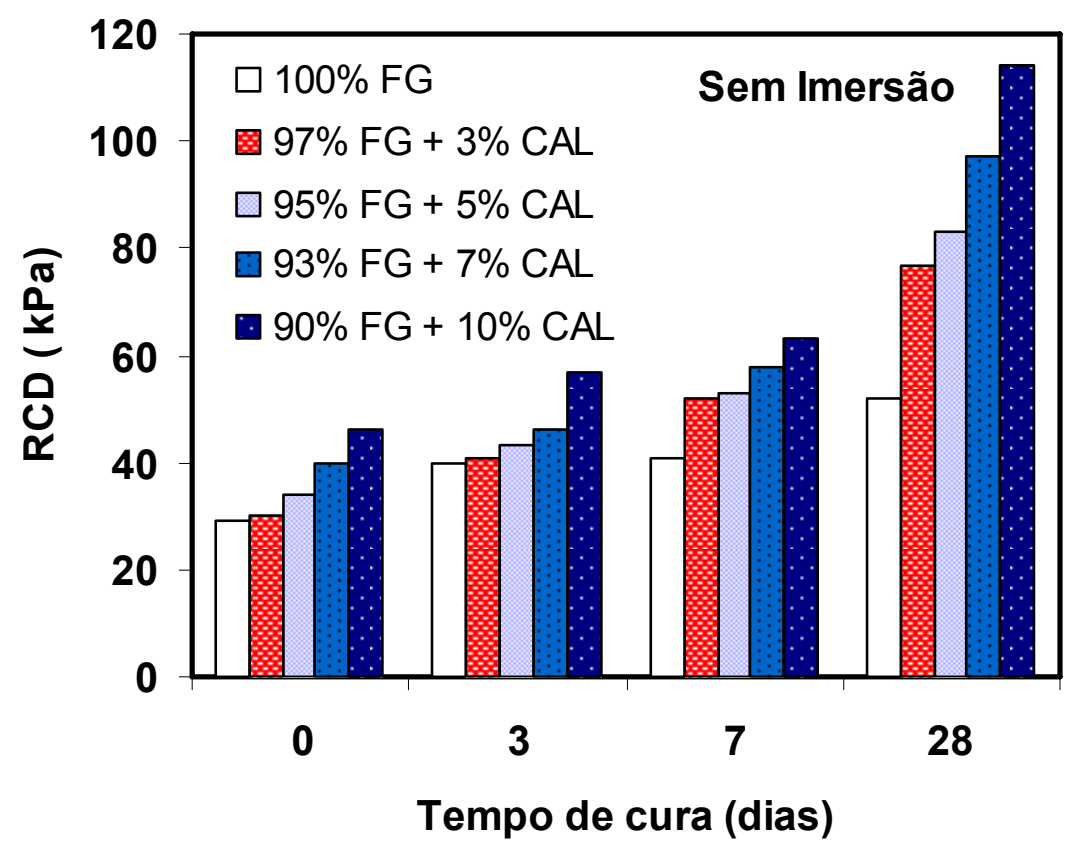

FIGURA 4.30 - Diagrama de barras - variação da resistência à tração por compressão diametral para misturas de fosfogesso e cal ensaiadas sem imersão

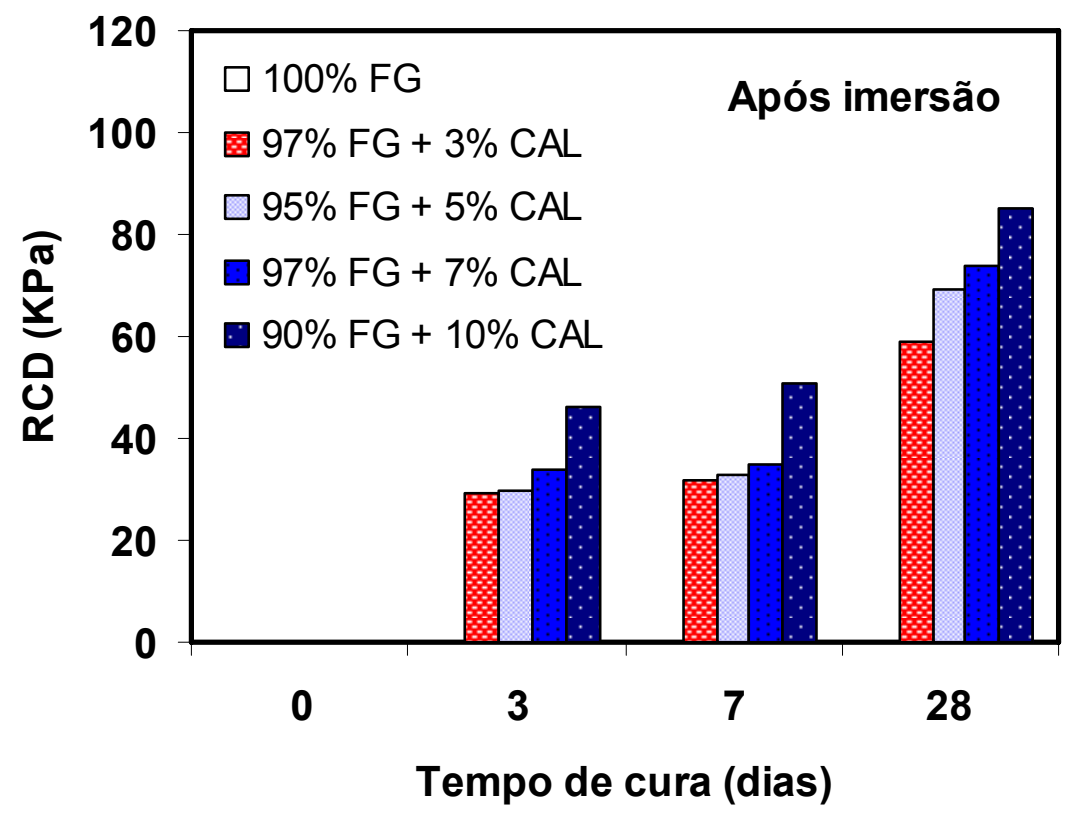

FIGURA 4.31 - Diagrama de barras - variação da resistência à tração por compressão diametral para misturas de fosfogesso e cal ensaiadas após imersão

Analisando-se os valores apresentados na Tabela 4.9 e as Figuras 4.28, 4.29, 4.30 e 4.31, observa-se que a adição de cal conduz ao aumento da resistência à tração por compressão diametral (RCD), à exceção das misturas não curadas e ensaiadas sem e após imersão em água. A adição de cal e o 
aumento do tempo de cura na RCD tem efeito semelhante ao descrito anteriormente para a RCS, indicando que os mecanismos de ação destas variáveis são semelhantes sob os dois tipos de solicitação. Levando-se em consideração os ensaios realizados sem imersão conforme ilustrado nas Figuras 4.28 e 4.30 e considerando-se valores médios calculados a partir dos resultados correspondentes a 3, 7 e 28 dias de cura, o ganho de resistência em relação ao fosfogesso puro é de $26 \%, 32 \%$, $48 \%$ e $72 \%$, respectivamente para os teores de 3\%, 5\%,7\% e 10\% de cal. Quando se comparam as variações de resistências à compressão simples e tração por compressão diametral com a adição da cal, o efeito positivo do aditivo é $48 \%$ maior na RCD do que na RCS.

Para os ensaios realizados após imersão em água, e conforme ilustrado nas Figuras 4.29 e 4.31, observa-se que o efeito positivo da adição de cal é ainda mais evidente, visto que a totalidade dos corpos-de-prova constituídos apenas por fosfogesso desintegraram-se para todos os tempos de cura, não permitindo a execução dos ensaios. Quando se analisa a ação da água sobre o fosfogesso estabilizado, e considerando-se valores médios calculados a partir dos tempos de cura de 3, 7 e 28 dias, a redução da RCD é de 30\%, 28\%, 30\% e $21 \%$, respectivamente, para os teores de $3 \%, 5 \%, 7 \%$ e $10 \%$ de cal, indicando que o efeito da cal, neste aspecto, varia pouco com o teor utilizado. Quando se comparam as variações de resistências à compressão e tração com a imersão, o efeito da água na diminuição da resistência é 58\% maior na RCS do que na RCD.

Os diagramas das Figuras 4.30 e 4.31 ilustram que o efeito positivo da cal torna-se realmente significativo para o teor de $10 \%$ de cal. Observa-se ainda que, para todos os teores de cal e para as duas condições de ensaio, as maiores resistências são alcançadas aos 28 dias.

Quando se comparam as variações de resistências à compressão e tração com a imersão, o efeito da água na diminuição da resistência é $58 \%$ maior na RCS do que na RCD.

Para se compararem entre os efeitos da cal ao solo com os da sua adição ao fosfogesso, a Tabela 4.10 apresenta valores de RCD determinados nesta pesquisa e por Molina (2004) para misturas de dois tipos de solo e $5 \%$ e $10 \%$ de cal, ensaiadas sem imersão em água. 
TABELA 4.10 - Resistência à tração por compressão diametral de misturas de solo e cal, e fosfogesso e cal

\begin{tabular}{ccc}
\hline Tipo de solo & Teor de cal (\%) & RCD aos 7 dias de cura \\
\hline \multirow{2}{*}{ Arenoso } & 5 & 34 \\
\multirow{2}{*}{ Argiloso } & 10 & 23 \\
& 5 & 74 \\
Fosfogesso & 10 & 74 \\
\hline \multirow{2}{*}{ Fon } & 5 & 53 \\
\end{tabular}

Analisando-se os valores apresentados na Tabela 4.10, observa-se que, à exceção da amostra com $5 \%$ e $10 \%$ de estabilizante adicionada ao tipo de solo argiloso, a mistura de fosfogesso e cal apresentou maior resistência à compressão diametral, considerada a mesma condição de ensaio, que as misturas de solo e cal. Comparando-se os valores médios calculados a partir das resistências correspondentes a todas as condições ensaiadas, as misturas de fosfogesso estabilizadas com cal apresentam RCD 28\% superior à das misturas de solo estabilizado com cal.

Para a comparação entre os efeitos da adição da cal e do cimento ao fosfogesso, a Tabela 4.11 apresenta valores de RCD determinados nesta pesquisa e por Parente (2002) para misturas de fosfogesso estabilizado com $7 \%$ e $10 \%$ do cimento CP II-E 32, ensaiadas sem imersão e após imersão em água.

Analisando-se os valores apresentados na Tabela 4.11, observa-se que, à exceção de amostras com $7 \%$ e $10 \%$ de estabilizante, curadas por 7 dias e ensaiadas nas duas condições, todas as misturas de fosfogesso e cimento apresentaram RCD superiores as das misturas estudadas nesta pesquisa. Comparando-se os valores médios calculados a partir das resistências correspondentes a todas as condições ensaiadas, as misturas estabilizadas com cal apresentam RCD 150\% inferior à das misturas estabilizadas com cimento. Assim, a vantagem do custo menor da cal, ficaria minimizada se for considerado apenas o aspecto de 7 dias de cura, para ambas as condições ensaiadas. 
TABELA 4.11 - Resistência à tração por compressão diametral de misturas de fosfogesso e cal, e fosfogesso e cimento

\begin{tabular}{ccccccc}
\hline & \multicolumn{3}{l}{ Resistência à tração por compressão diametral $(\mathbf{k P a})$} & \multicolumn{2}{c}{$\begin{array}{c}\text { Perda de RCD } \\
\text { Por imersão (\%) }\end{array}$} \\
\cline { 2 - 5 } & $\mathbf{7}$ dias & $\mathbf{2 8}$ dias & $\mathbf{7}$ dias & $\mathbf{2 8}$ dias & $\mathbf{7}$ dias & $\mathbf{2 8}$ dias \\
$7 \%$ de cal & 58 & 97 & 35 & 74 & 40 & 24 \\
$7 \%$ de cimento & 40 & 170 & nd & 140 & nd & 18 \\
\hline $10 \%$ de cal & 63 & 114 & 51 & 85 & 19 & 25 \\
$10 \%$ de cimento & 40 & 200 & nd & 170 & nd & 15 \\
\hline
\end{tabular}

\subsubsection{Influência do tempo de cura}

O tempo de cura é um fator importante no desenvolvimento da resistência à tração por compressão diametral de misturas estabilizadas com cal. As Figuras 4.32 e 4.33 ilustram, respectivamente, a variação da resistência à tração por compressão diametral com o tempo de cura para corpos de prova ensaiados sem imersão e após imersão prévia em água. Complementarmente, as Figuras 4.34 e 4.35 apresentam estas mesmas variáveis através de diagrama de barras.

Analisando-se os valores da Tabela 4.9 e as Figuras 4.32, 4.33, 4.34 e 4.35, observa-se que o acréscimo do tempo de cura conduz ao aumento da resistência à tração por compressão diametral (RCD), para todos os teores de cal e para as duas condições de ensaio. 


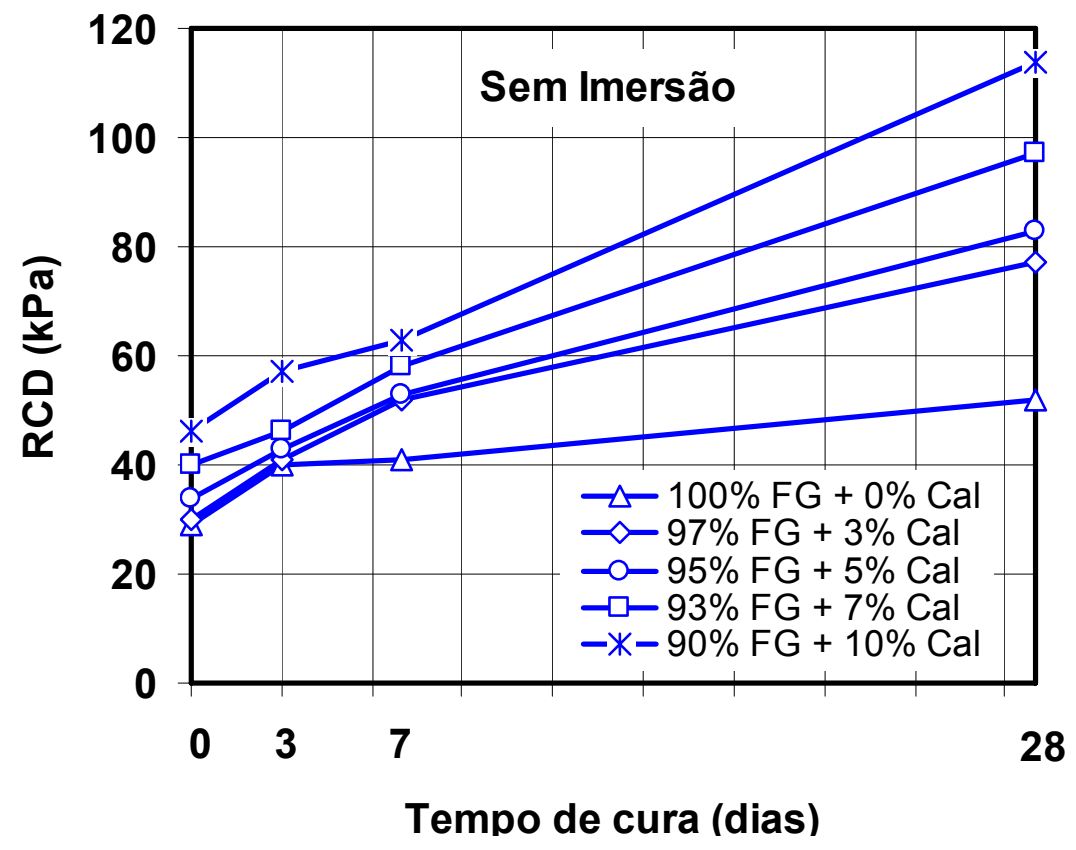

FIGURA 4.32 - Variação da resistência à tração por compressão diametral para mistura de fosfogesso e cal ensaiadas sem imersão

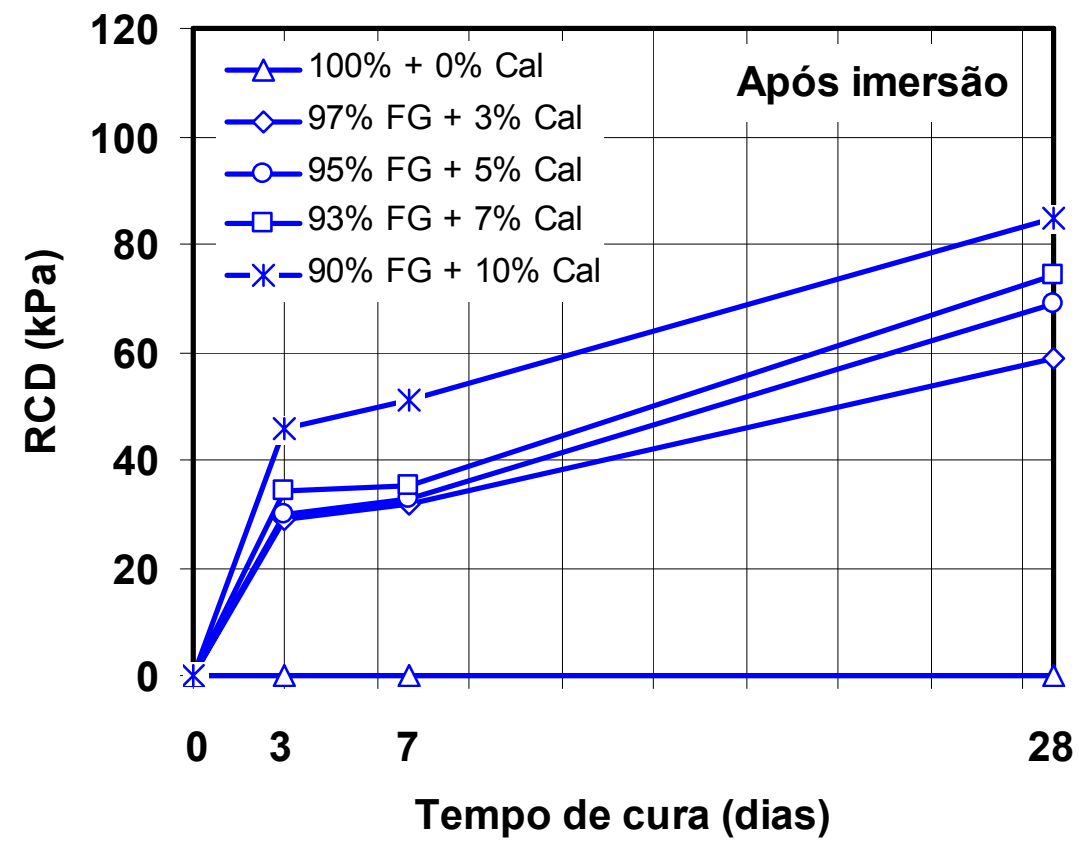

FIGURA 4.33 - Variação da resistência à tração por compressão diametral para misturas de fosfogesso e cal ensaiadas após imersão 


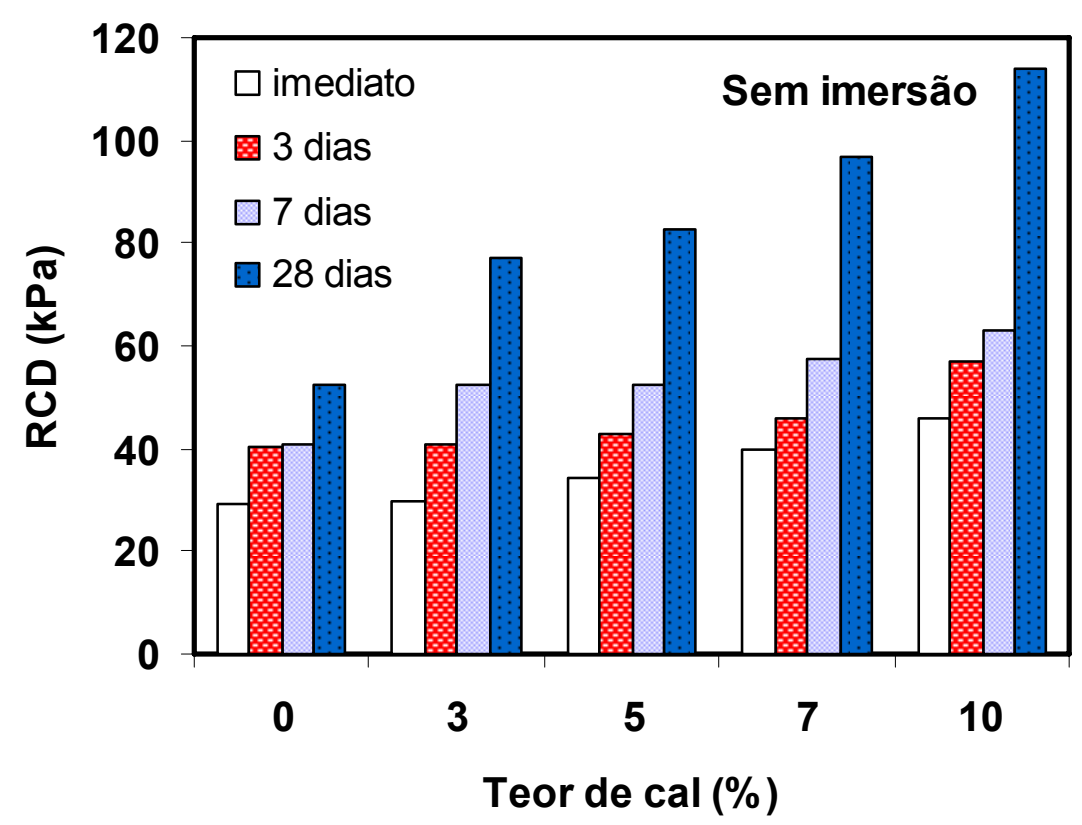

FIGURA 4.34 - Diagrama de barras - variação da resistência à tração por compressão diametral ensaiadas sem imersão

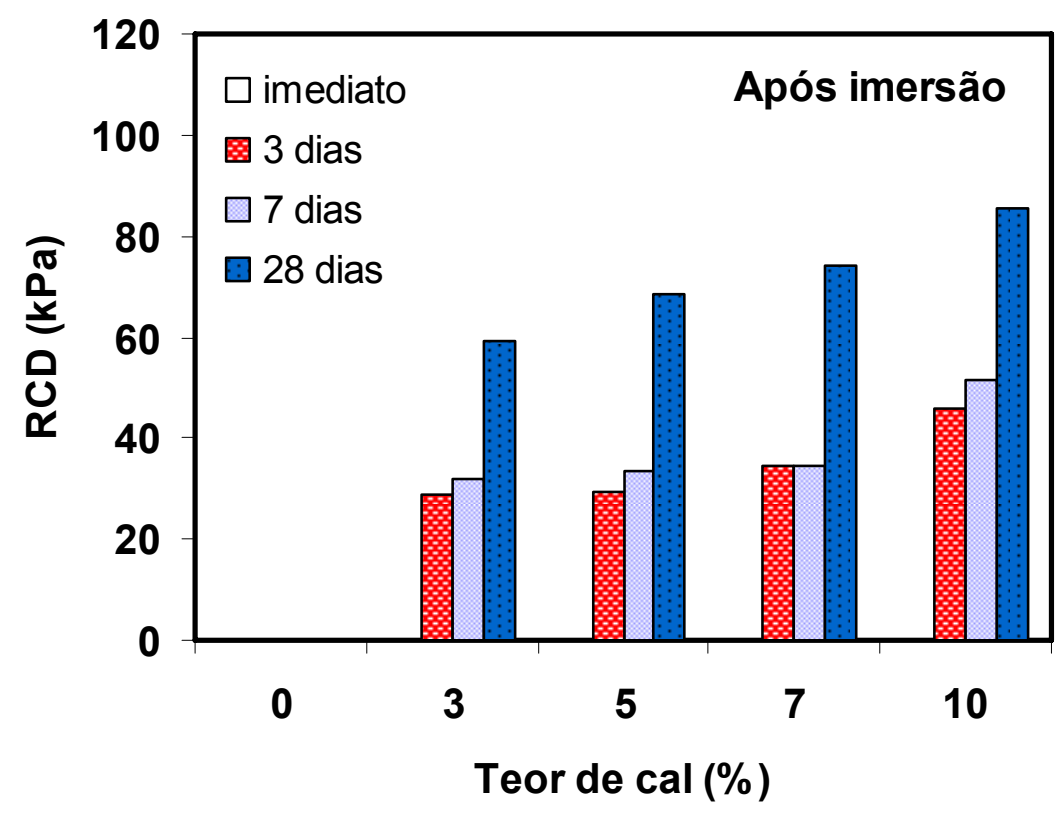

FIGURA 4.35 - Diagrama de barras - variação da resistência à tração por compressão diametral ensaiadas após imersão

Para os ensaios realizados sem imersão, vide Figuras 4.32 e 4.34, e considerando-se valores médios calculados a partir dos resultados correspondentes a todos os teores de cal, excetuando o fosfogesso puro, observa-se que o ganho de resistência à tração por compressão diametral em relação às amostras ensaiadas sem cura é de $25 \%, 51 \%$ e $147 \%$, para os tempos de cura 3,7 e 28 dias, respectivamente. Assim, conclui-se que apenas 
após 28 dias de cura, o ganho de RCD com o aumento do tempo de cura tornase realmente expressivo, semelhante ao observado para os valores obtidos nos ensaios de compressão simples. A não observação do efeito positivo da cal em corpos de prova ensaiados imediatamente após compactação indica que a ação do aditivo a curto prazo (troca cátion-iônica), não se processa, restando apenas o efeito da cimentação (reação pozolânica da cal com o fosfogesso), que se dá a longo prazo. Neste sentido, Graves (1987) já observara que a ação cimentante da cal sobre materiais calcários, a exemplo do fosfogesso, é muito elevada.

Para os ensaios realizados após imersão em água, vide Figuras 4.33 e 4.35, a importância da cura torna-se ainda mais evidente, pois todos os corpos de prova não curados desintegraram-se durante o processo. Nestas condições e considerando-se valores médios calculados a partir dos resultados correspondentes a todos os teores de cal, o ganho de resistência à tração por compressão diametral nos períodos de 3 a 7 dias, e de 3 a 28 dias, é de $9 \%$ e $106 \%$, respectivamente.

Considerando-se o conjunto de resultados dos ensaios de compressão simples e o conjunto dos ensaios de compressão diametral, observa-se que na média, a RCD é $8,5 \%$ maior da RCS, sendo que para misturas solo-cal este valor é de aproximadamente 10\%. Finalmente, quando se analisa o efeito positivo da adição da cal na resistência das misturas, conclui-se que este é consideravelmente maior nos resultados obtidos nos ensaios de compressão diametral do que aqueles obtidos nos ensaios de compressão simples.

Comparando-se os valores de resistência à tração por compressão diametral obtidos nesta pesquisa com os valores determinados por Silvestre (2002) para misturas de fosfogesso e cimento, conforme apresentado na Tabela 4.11, observa-se que o efeito do tempo de cura é mais marcante para esta última do que para as misturas de fosfogesso estabilizadas com cal.

\subsubsection{Relação entre resistência à tração por compressão diametral, tempo de cura e teor de cal}

Foram realizadas regressões múltiplas, utilizando-se a resistência à tração por compressão diametral como variável dependente e o tempo de cura e o teor de cal como variáveis independentes. Assim, determinaram-se as 
Equações 4.5 e 4.6 considerando-se, respectivamente, os resultados das misturas ensaiadas, sem imersão e após imersão previam em água.

$$
\begin{array}{ll}
\mathrm{RCD}=18,41 .(\mathrm{TC})^{0,33} \cdot(\mathrm{cal})^{0,30} & \mathrm{R}^{2}=0,97 \\
\mathrm{RCD}=11,20 .(\mathrm{TC})^{0,37} \cdot(\mathrm{cal})^{0,34} & \mathrm{R}^{2}=0,94
\end{array}
$$

onde:

$\mathrm{RCD}$ - resistência à tração por compressão diametral $(\mathrm{kPa})$;

TC - tempo de cura (dias);

(cal) -variação do teor de cal (\%).

Com estas equações apresentadas acima, pretendeu-se analisar se os valores obtidos de RCD neste modelo proposto são equivalentes aos obtidos com os valores em laboratório. Vale salientar que foi excluído o tempo de cura de zero dias, bem como o teor de $0 \%$ de cal para este modelo proposto. A influência do teor de cal, tempo de cura e condição de ensaio foi festa pela análise de variância.

As Equações 4.5 e 4.6 apresentam coeficientes de determinação $\left(R^{2}\right)$ iguais a 0,97 e 0,94 , respectivamente. Os valores elevados de $R^{2}$ indicam que estas equações representam com fidelidade a relação entre as variáveis consideradas. Este fato também é evidenciado analisando-se as Figuras 4.36 e 4.37 que apresentam valores de RCD calculados a partir das Equações 4.5 e 4.6, respectivamente, e os valores correspondentes determinados nos ensaios de laboratório. 


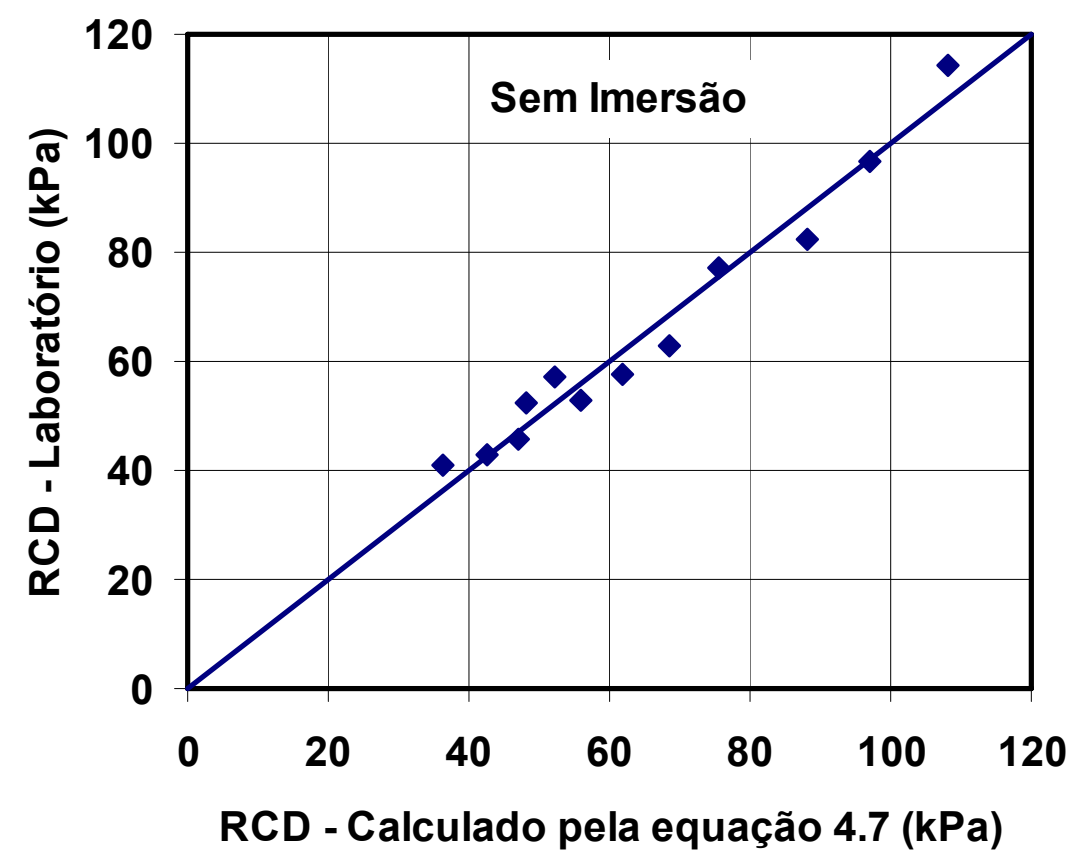

FIGURA 4.36 - Valores de RCD: equação 4.5 "versus" laboratório

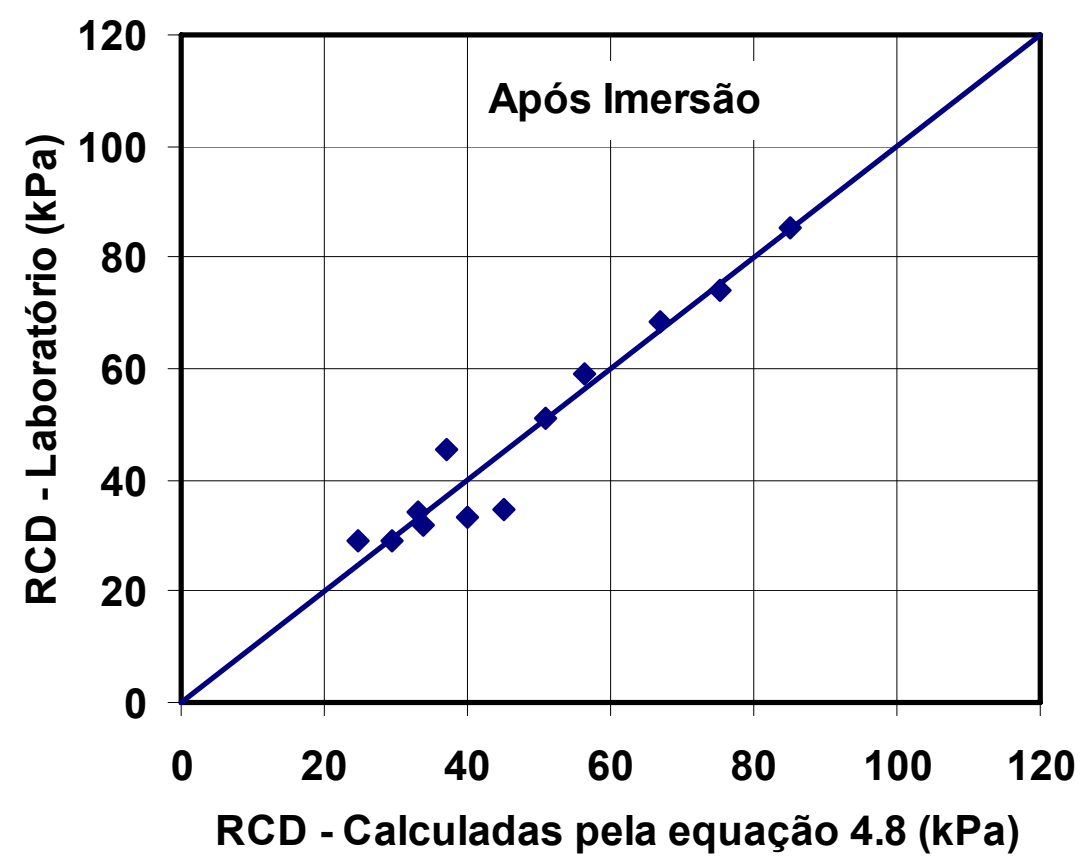

FIGURA 4.37 - Valores de RCD: equação 4.6 "versus" laboratório

As Figuras 4.38 e 4.39 ilustram os modelos representados pelas Equações 4.5 e 4.6, respectivamente. 


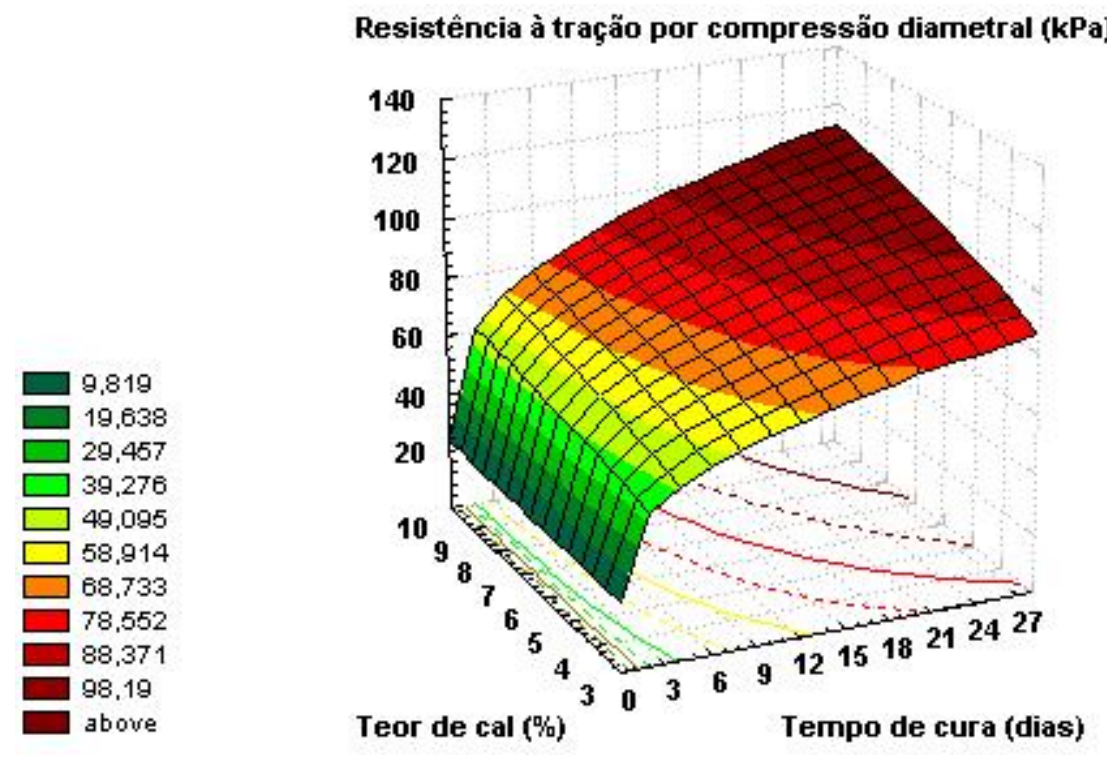

FIGURA 4.38 - Variação da resistência à tração por compressão diametral com o tempo de cura e teor de cal - sem imersão

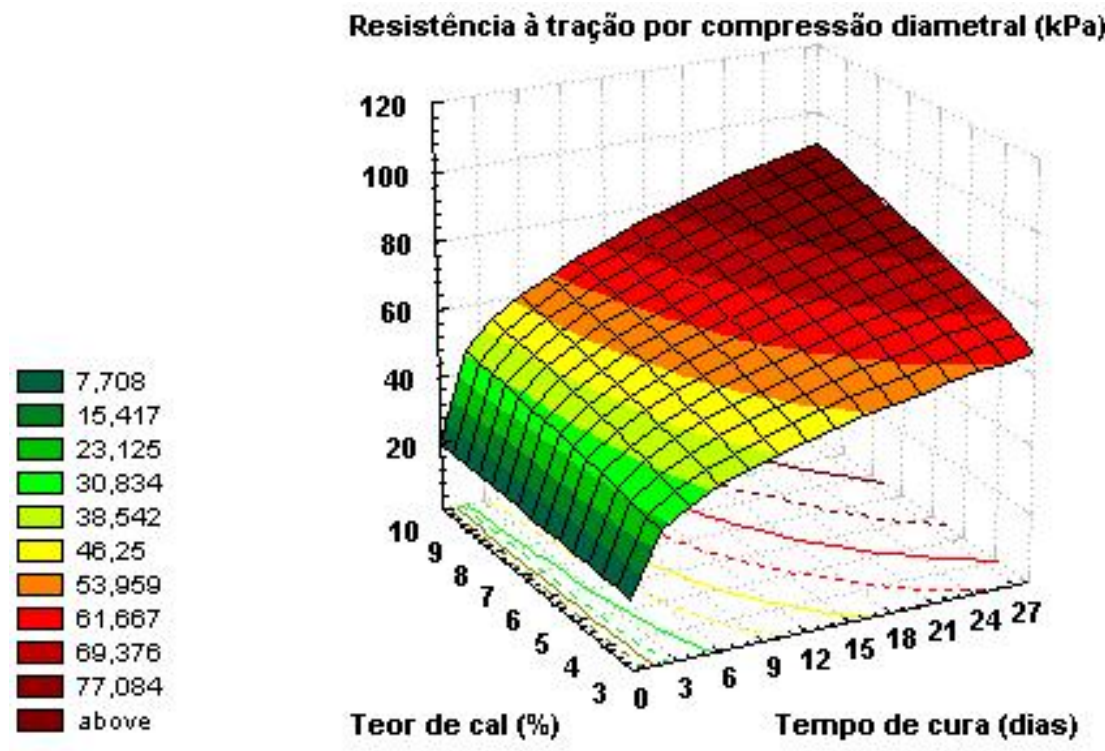

FIGURA 4.39 - Variação da resistência à tração por compressão diametral com o tempo de cura e teor de cal - após imersão

Fez-se ainda um estudo de variância, verificando o nível de significância da influência da imersão em água, do tempo de cura e do teor de cal, incluindo as interações entre esses fatores, no resultados de RCD. O nível de confiança considerado foi de $95 \%$ e os resultados detalhados da análise são apresentados no Anexo F.

Na Tabela 4.12 são listados os resultados das análises feitas. Estas análises estão baseadas no teste $F$ de Snedecor (GARCIA-DIAZ \& PHILLIPS, 1995). Com base neste teste, uma hipótese é considerada significativa quando 
o $F_{\text {teórico }}$ for inferior ao $F_{\text {calculado, sendo o }} F_{\text {teórico }}$ tabelado em funçào da razão do grau de liberdade do erro.

As fontes de variação ou tratamentos $A, B, C, A B, A C, B C$ e $A B C$ apresentados na Tabela 4.12 são enumeradas em seguida:

- A: da variação da condição do ensaio (sem imersão e com imersão);

- B:do tempo de cura;

- C: do teor de cal $(0 \%, 3 \%, 5 \%, 7 \%$ e $10 \%)$

- $A B$ : da condição de ensaio em conjunto com o tempo de cura;

- AC: da condição do ensaio em conjunto com o teor de cal e;

- BC: do tempo de cura em conjunto com o teor de cal;

- $A B C:$ da condição do ensaio em conjunto com o tempo de cura e com o teor de cal.

Tabela 4.12 - Influência das variáveis do estudo sobre os resultados do (RCD)

\begin{tabular}{|c|c|c|c|c|c|c|}
\hline $\begin{array}{l}\text { Fonte de } \\
\text { Variação }\end{array}$ & $\begin{array}{c}\text { Graus de } \\
\text { Liberdade } \\
\text { (GL) }\end{array}$ & $\begin{array}{c}\text { Soma dos } \\
\text { quadrados } \\
\text { (SQ) }\end{array}$ & $\begin{array}{c}\text { Quadrado } \\
\text { médio } \\
\text { QM=SQ/GL }\end{array}$ & $F_{\text {calculado }}$ & $F_{\text {teórico }}$ & significativo? \\
\hline A & 1 & 25150 & 25150 & 2448 & 3,84 & $\operatorname{sim}$ \\
\hline B & 3 & 56286 & 18762 & 1826 & 2,60 & $\operatorname{sim}$ \\
\hline C & 4 & 23815 & 5953 & 579,58 & 2,37 & $\operatorname{sim}$ \\
\hline$A B$ & 3 & 1436 & 479 & 46,60 & 2,60 & $\operatorname{sim}$ \\
\hline$A C$ & 4 & 2330 & 583 & 56,71 & 2,37 & $\operatorname{sim}$ \\
\hline $\mathrm{BC}$ & 12 & 10375 & 864 & 84,16 & 1,75 & $\operatorname{sim}$ \\
\hline$A B C$ & 12 & 2015 & 168 & 16,35 & 1,75 & \\
\hline Erro & 117 & 1202 & 10,3 & & & \\
\hline Total & 159 & 122622 & & & & \\
\hline
\end{tabular}

A Tabela 4.12 mostra que o teor de cal, o tempo de cura e a condição de ensaio e as interações entre as variáveis influenciam de maneira significativa os resultados da resistência à tração por compressão diametral determinados nos ensaios.

\subsubsection{Comparação das resistências à compressão simples e resistência à tração por compressão diametral}

Analisando-se as os gráficos de barra apresentados nas Figuras 4.40, $4.41,4.42$ e 4.43 , para os respectivos tempos de cura, observa-se que 0 
padrão de variação das resistências à compressão simples e diametral com o teor de cal é muito diverso quando se comparam estas misturas.

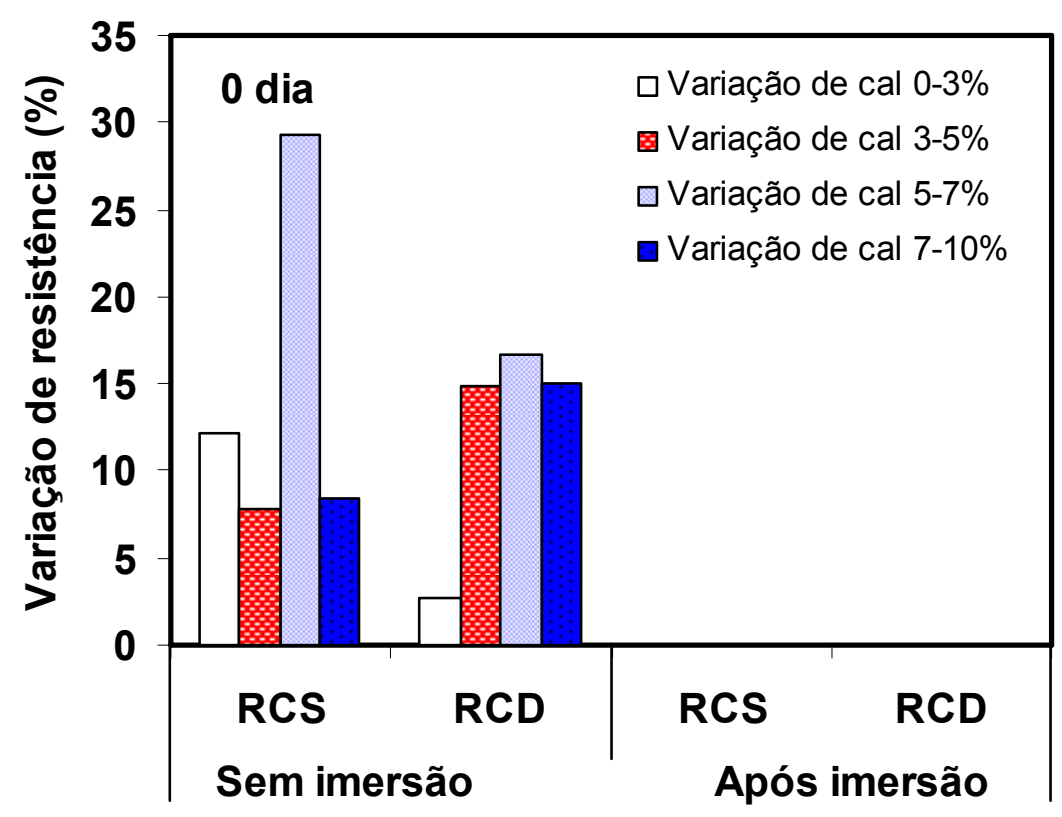

FIGURA 4.40 - Variação relativa das (RCS) e (RCD) em função do teor de cal para misturas ensaiadas sem imersão e após imersão para o tempo de cura imediato

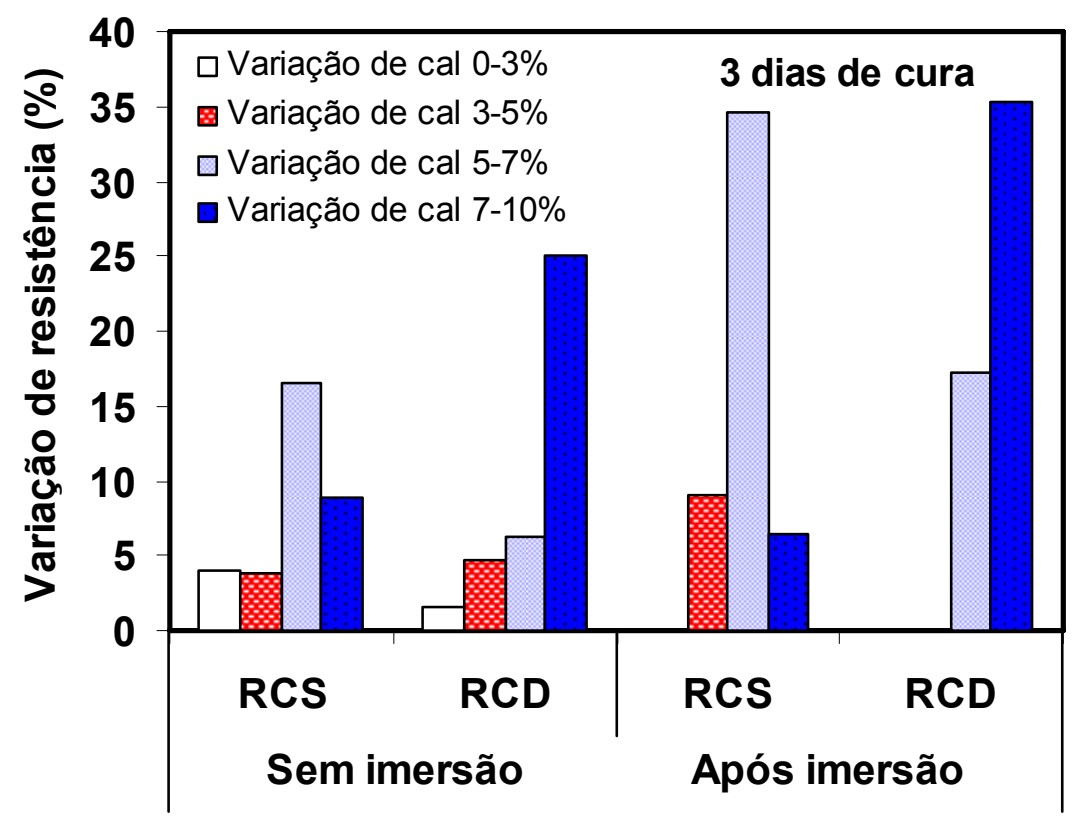

FIGURA 4.41 - Variação relativa das (RCS) e (RCD) em função do teor de cal para misturas ensaiadas sem imersão e com imersão para o período de cura de 3 dias 


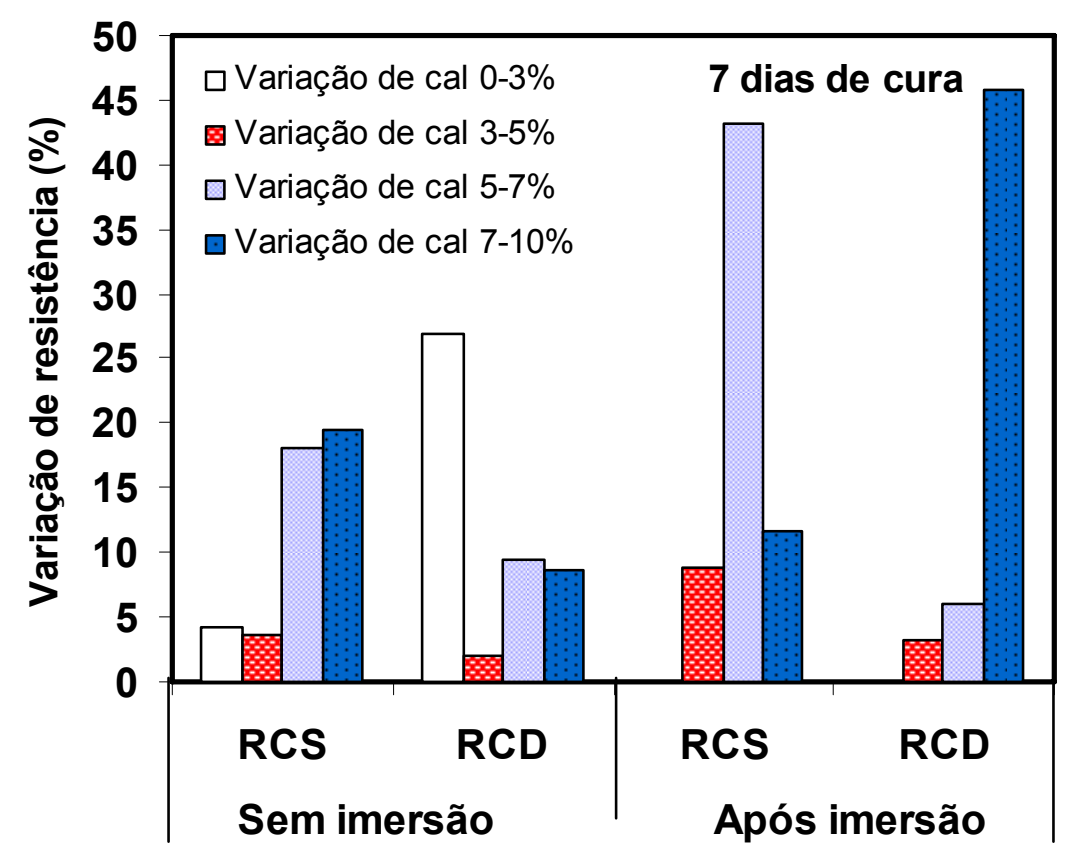

FIGURA 4.42 - Variação relativa das (RCS) e (RCD) em função do teor de cal para misturas ensaiadas sem imersão e com imersão, para 7 dias de cura

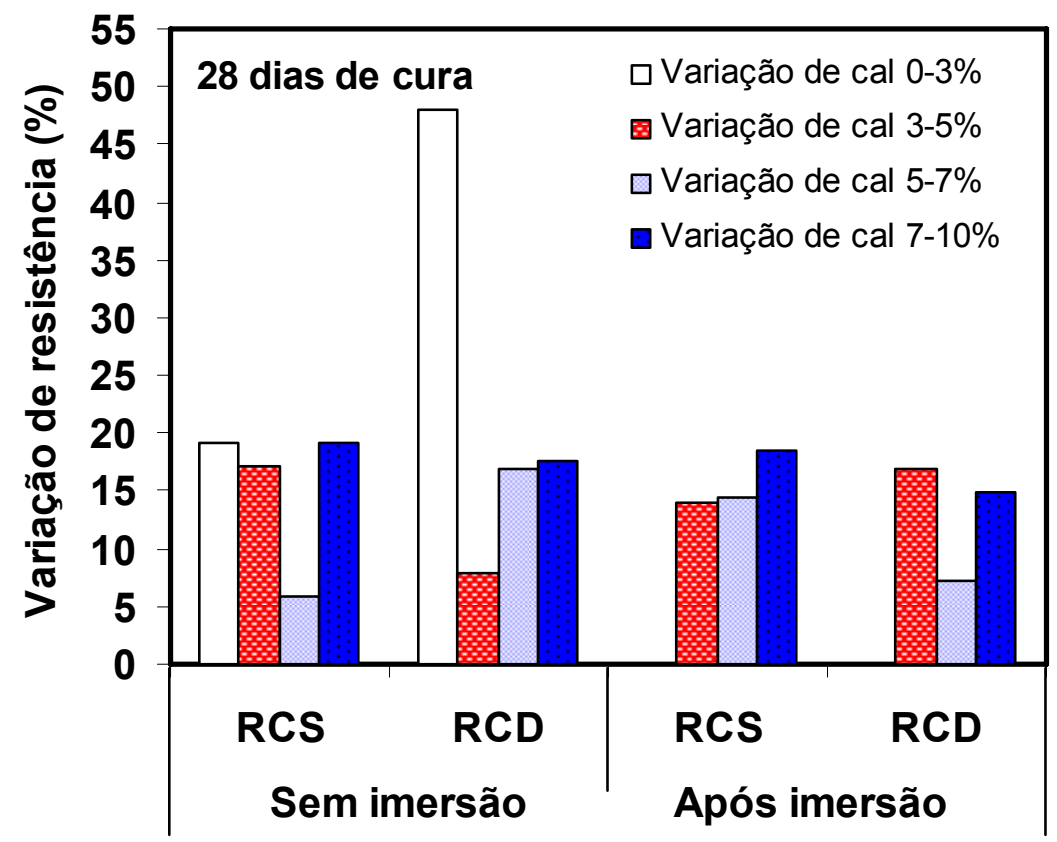

FIGURA 4.43 - Variação relativa das (RCS) e (RCD) em função do teor de cal para misturas ensaiadas sem imersão e com imersão, para 28 dias de cura 


\subsubsection{Envoltória de resistência de Mohr- Coulomb}

As resistências à compressão simples e diametral permitem que se determine a envoltória de resistência de Mohr-Coulomb em termos de tensões totais das misturas ensaiadas.

Para se analisar o efeito do teor de cal e do tempo de cura na resistência das misturas, foi considerado a variação dos parâmetros coesão (c) e ângulo de atrito interno $(\phi)$ com estas variáveis.

As Tabelas 4.13 e 4.14 apresentam os parâmetros de resistência correspondentes a corpos de prova ensaiados sem e após imersão em água, respectivamente. As envoltórias correspondentes são apresentadas no Anexo G.

TABELA 4.13 - Variação da coesão e ângulo de atrito interno com o teor de cal e tempo de cura - sem imersão

\begin{tabular}{ccccccccc}
\hline Cal & \multicolumn{2}{c}{$\mathbf{0}$ dias } & \multicolumn{2}{c}{3 dias } & \multicolumn{2}{c}{$\mathbf{7}$ dias } & \multicolumn{2}{c}{$\mathbf{2 8}$ dias } \\
\cline { 2 - 8 }$(\%)$ & $\mathbf{c ~ ( k P a )}$ & $\phi\left(^{\circ}\right)$ & $\mathbf{c ~ ( k P a )}$ & $\phi\left(^{\circ}\right)$ & $\mathbf{c ~ ( k P a )}$ & $\phi\left(^{\circ}\right)$ & $\mathbf{c ~ ( k P a )}$ & $\phi\left(^{\circ}\right)$ \\
\hline 0 & 68 & 61 & 84 & 61 & 86 & 56 & 102 & 51 \\
3 & 66 & 59 & 86 & 56 & 102 & 52 & 141 & 46 \\
5 & 74 & 58 & 90 & 56 & 104 & 52 & 156 & 48 \\
7 & 90 & 60 & 100 & 58 & 117 & 54 & 177 & 45 \\
10 & 101 & 58 & 118 & 55 & 131 & 56 & 209 & 45 \\
\hline
\end{tabular}

TABELA 4.14: Variação da coesão e ângulo de atrito interno com o teor de cal e tempo de cura - após imersão

\begin{tabular}{ccccccccc}
\hline Cal & \multicolumn{2}{c}{ 0 dias } & \multicolumn{2}{c}{3 dias } & \multicolumn{2}{c}{7 dias } & \multicolumn{2}{c}{28 dias } \\
$(\%)$ & $\mathbf{c ~ ( k P a )}$ & $\phi\left(^{\circ}\right)$ & $\mathbf{c ~}(\mathbf{k P a})$ & $\phi\left(^{\circ}\right)$ & $\mathbf{c ~ ( k P a )}$ & $\phi\left(^{\circ}\right)$ & $\mathbf{c}(\mathbf{k P a})$ & $\phi\left(^{\circ}\right)$ \\
\hline 0 & nd & nd & nd & nd & nd & nd & nd & nd \\
3 & nd & nd & 57 & 51 & 63 & 52 & 109 & 46 \\
5 & nd & nd & 57 & 53 & 66 & 53 & 126 & 46 \\
7 & nd & nd & 62 & 44 & 78 & 59 & 138 & 48 \\
10 & nd & nd & 81 & 37 & 103 & 51 & 160 & 49 \\
\hline
\end{tabular}

Analisando-se os valores das Tabelas 4.13 e 4.14 , observa-se que a adição de cal praticamente não altera os parâmetros de resistência correspondentes a amostras ensaiadas sem cura. Para as demais, há uma variação do ângulo de atrito interno muito pouco significativa e um crescimento da coesão com o aumento do teor de cal e do tempo de cura. Este fato é devido à ação cimentante da cal, que se processa ao longo do tempo, e que se reflete apenas no valor da coesão. Confirma-se assim a observação anterior, 
de que o efeito positivo da adição da cal é mais efetivo na resistência à tração do que na resistência a compressão.

Tomando-se valores médios calculados para todas as condições, excetuando-se o fosfogesso puro e ensaios sem cura, e comparando-se a coesão correspondente a corpos de prova ensaiados sem e após imersão, observa-se que a água provoca uma diminuição de $36 \%$ no valor desta variável.

Para se compararem entre os efeitos da adição da cal ao solo com os da sua adição ao fosfogesso, a Tabela 4.15 apresenta valores de coesão (c) e ângulo de atrito interno $(\phi)$ determinados nesta pesquisa e por Molina (2004) para misturas de dois tipos de solo e $5 \%$ e $10 \%$ de cal, ensaiadas sem imersão em água aos 7 dias de cura.

TABELA 4.15 - Valores de c e $\phi$ de misturas de solo e cal, e fosfogesso e cal

\begin{tabular}{cccc}
\hline Tipo de material & Teor de cal (\%) & $\mathbf{c ~ ( k P a )}$ & $\phi($ grau $)$ \\
\hline \multirow{2}{*}{ solo } & 5 & 107 & 50 \\
& 10 & 92 & 50 \\
\hline \multirow{2}{*}{ fosfogesso } & 5 & 104 & 52 \\
& 10 & 131 & 56 \\
\hline
\end{tabular}

Analisando-se os valores apresentados na Tabela 4.15, observa-se que à exceção das amostras com $5 \%$ de cal, todas as misturas de fosfogesso e cal apresentaram coesão superiores as das misturas de solo cal. Comparandose os valores de $\phi$, todas as misturas de fosfogesso e cal apresentaram valores superiores as das misturas de solo cal, para todos os teores de cal analisados.

Comparando-se os valores médios calculados de coesão e de ângulo de atrito interno correspondentes a todas as condições ensaiadas, as misturas de fosfogesso estabilizadas com cal apresentam valores de c e $\phi 20 \%$ e $8 \%$ superiores à das misturas de solo cal, respectivamente.

\subsection{6 Índice de Suporte Califórnia (CBR)}

O ensaio de CBR tem sido muito utilizado na avaliação do desempenho de misturas estabilizadas, embora este ensaio, segundo a State of the art 5 Lime stabilization (TRB, 1987), não seja o ensaio mais apropriado para a 
avaliação de solos estabilizados. Devido a que freqüentemente são alcançados resultados superiores a $100 \%$, que têm pouca utilidade prática e não são significativos como medidas de resistência ou estabilidade. Normalmente, os materiais que apresentam CBR superior a 100\% apresentaram também altas resistências à compressão e tração, sendo estes melhores ensaios para avaliar a resistência. Neste estudo o ensaio de CBR foi realizado com um enfoque especulativo.

O CBR mínimo para camadas estabilizadas granulometricamente adotado pelo DER-SP é de $30 \%$ para camada sub-base e $60 \%$ para camada base. O resumo dos resultados obtidos nestes ensaios está apresentado no anexo $D$.

O ensaio de CBR foi realizado para todos os teores de cal proposto nesta pesquisa. Os corpos de prova ficaram na câmera úmida por um período de 7 dias, e posteriormente ficaram submersos em água por um período de 4 dias, totalizando um período de cura de 11 dias.

A Tabela 4.16 apresenta os valores de CBR e expansão para todas as misturas estudadas, bem como a diferença e o ganho relativo do CBR com a adição de cal ao fosfogesso. A expansão só foi medida no período em que os corpos de prova ficaram submersos em água por 4 dias. A Figura 4.44 ilustra a variação do CBR paras as misturas estudadas.

TABELA 4.16 - Valores de CBR e expansão para o fosfogesso puro e para as misturas de fosfogesso e cal.

\begin{tabular}{ccccc}
\hline $\begin{array}{c}\text { Teor de cal } \\
(\%)\end{array}$ & $\begin{array}{c}\text { Teor de } \\
\text { FG (\%) }\end{array}$ & CBR (\%) & Ganho (\%) & $\begin{array}{c}\text { Expansão } \\
(\%)\end{array}$ \\
\hline 0 & 100 & 16 & & 0,17 \\
3 & 97 & 54 & 238 & 0 \\
5 & 95 & 56 & 250 & 0 \\
7 & 93 & 65 & 306 & 0 \\
10 & 90 & 71 & 344 & 0 \\
\hline
\end{tabular}




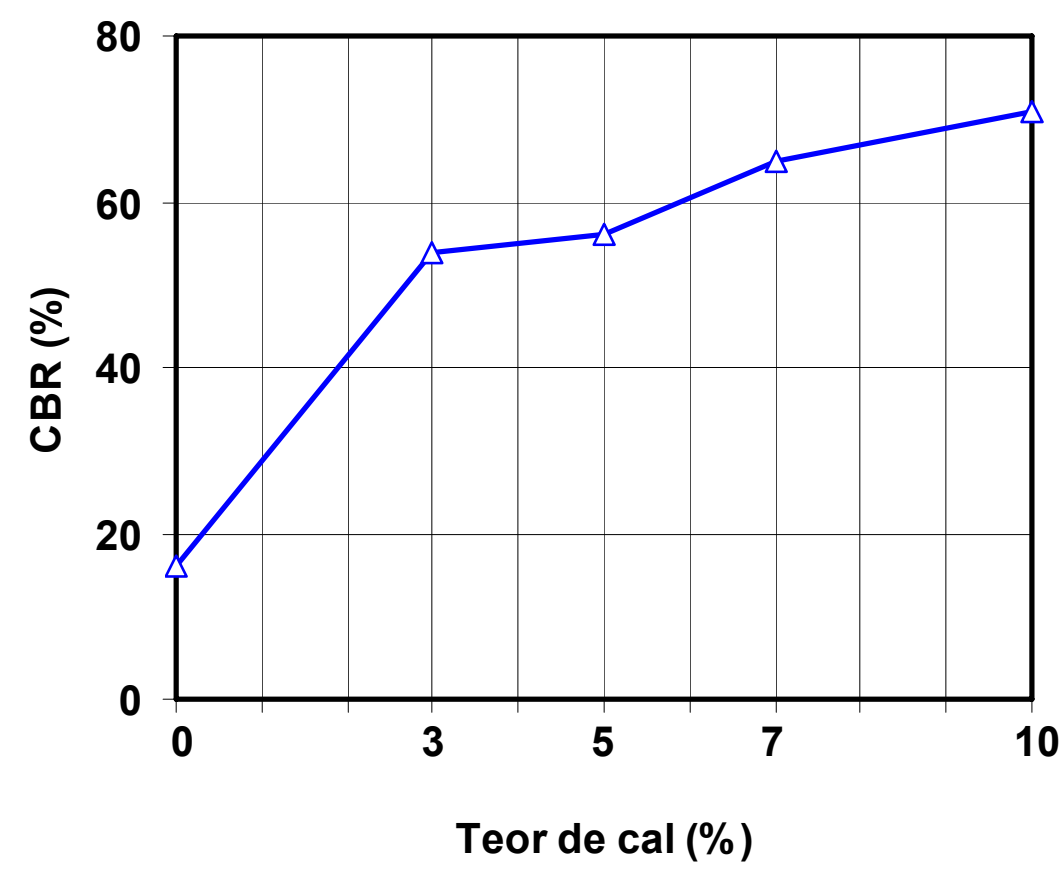

FIGURA 4.44 - Índice de Suporte Califórnia em função do teor de cal para misturas de fosfogesso e cal

Analisando-se a Tabela 4.16 e Figura 4.44, observa-se que o padrão de variação do CBR é similar aos verificados anteriormente para a RCS e a RCD. O fosfogesso puro é muito suscetível à ação da água, apresentando CBR igual a $16 \%$. A adição de $3 \%, 5 \%, 7 \%$ e $10 \%$ de cal conduz a valores de CBR de $54 \%, 56 \%, 65 \%$ e $71 \%$, respectivamente. Portanto, o crescimento do CBR corresponde a $238 \%, 250 \%, 306 \%$ e $344 \%$, respectivamente. Apesar de não ter sido analisada a influência do tempo de cura, a extensão do período em que os corpos de prova foram mantidos em câmara úmida antes à imersão em água, provavelmente conduziria a valores mais expressivos de CBR.

Analisando-se a Tabela 4.16 a Figura 4.45, observa-se que o fosfogesso puro apresentou uma expansão de $0,17 \%$, que se anulou com a adição de cal. 


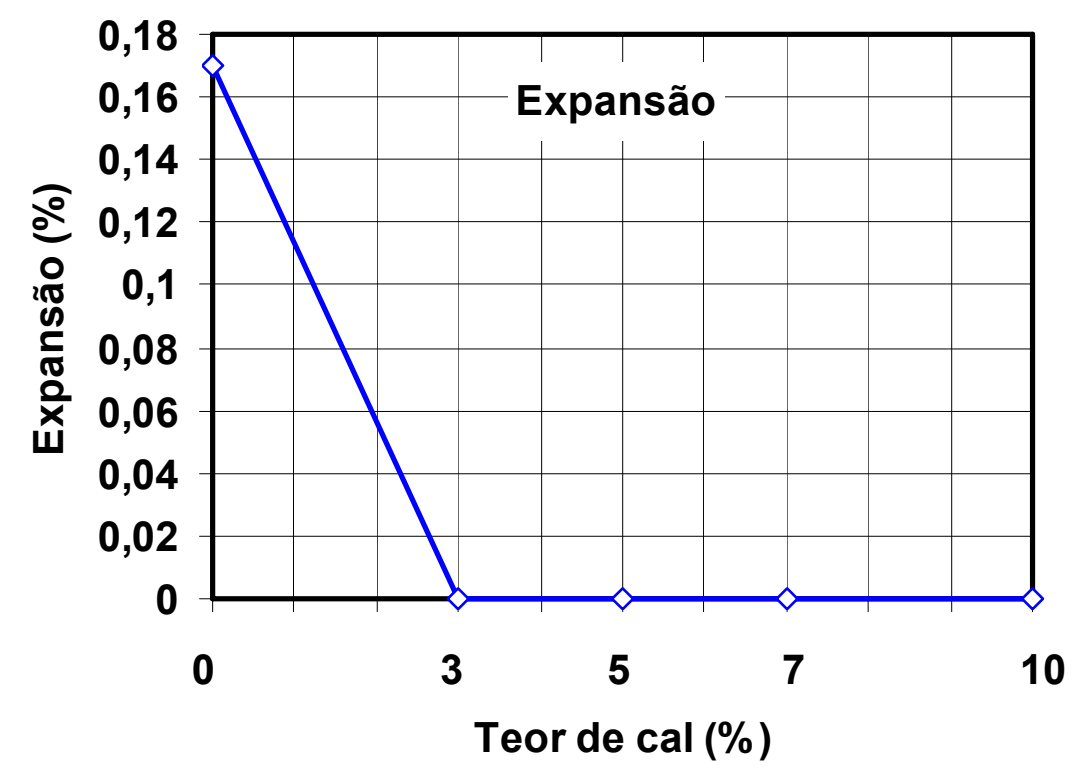

Figura 4.45 - Expansão das misturas de fosfogesso e cal em função do teor de cal

Com o objetivo de analisar os resultados dos ensaios para a determinação do CBR, fez-se estudo de variância dos resultados, verificandose a significância da influência do teor de cal nos resultados dos experimentos. O nível de confiança considerado foi de $95 \%$. Os resultados da análise são apresentados de forma mais detalhada no Anexo F.

Na Tabela 4.17 são listados os resultados das análises feitas. A fonte de variação ou tratamento apresentado na Tabela 4.17 é enumerada em função o teor de cal $(0 \%, 3 \%, 5 \%, 7 \%$ e $10 \%)$.

Tabela 4.17 - Influência das variáveis do estudo sobre o ensaio de CBR

\begin{tabular}{ccccccc}
\hline $\begin{array}{c}\text { Fonte de } \\
\text { Variação }\end{array}$ & $\begin{array}{c}\text { Graus de } \\
\text { Liberdade } \\
\text { (GL) }\end{array}$ & $\begin{array}{c}\text { Soma dos } \\
\text { quadrados } \\
\text { (SQ) }\end{array}$ & $\begin{array}{c}\text { Quadrado } \\
\text { médio } \\
\text { QM=SQ/GL }\end{array}$ & $\mathbf{F}_{\text {calculado }}$ & $\mathbf{F}_{\text {teórico }}$ & significativo? \\
\hline A & 1 & 1845,2 & 1845,2 & 461,3 & 6,61 & $\operatorname{sim}$ \\
\hline
\end{tabular}

A Tabela 4.17 mostra que a variação do teor de cal, influência de maneira significativa os resultados dos ensaios de CBR. 


\subsection{ANÁLISE DOS RESULTADOS DOS ENSAIOS DE LIXIVIAÇÃO, SOLUBILIZAÇÃO E ABSORÇÃO ATÔMICA}

Os ensaios de solubilização e lixiviação forneceram subsídios para as análises das impurezas presentes no fosfogesso puro, bem como nas misturas de fosfogesso e cal propostas na pesquisa.

As amostras lixiviadas e solubilizadas foram encaminhas ao laboratório de Química ambiental do IQSC. As análises das impurezas forame realizadas por absorção atômica de raio $x$. Os resultados obtidos com as amostras de fosfogesso puro estão na Tabela 4.18.

TABELA 4.18 - Análise das impurezas obtidas de amostras soltas e compactadas de fosfogesso puro.

\begin{tabular}{cccccc}
\hline Arsênio (\%) & Bário (\%) & Cádmio (\%) & Chumbo (\%) & Selênio (\%) & Prata (\%) \\
\hline 0,02 & 0,5 & 0,003 & 0,03 & 0,01 & 0,002 \\
\hline
\end{tabular}

Com os resultados obtidos na Tabela 4.18, observa-se que as impurezas verificadas no fosfogesso foram: arsênio, cádmio, chumbo, selênio e prata. As porcentagens dessas impurezas podem variar de acordo com o processo de fabricação do ácido fosfórico, da rocha fosfática e do tipo de fosfogesso obtido. Se comparar os valores obtidos na Tabela 4.18, com os padrões mínimos apresentados na norma NBR 10004 CLASSIFICAÇÃO DE RESÍDUOS SÓLIDOS, esse resíduo é classificado com classe II A não inerte. Não sendo considerado perigo para o meio ambiente. Mas vale salientar que esses parâmetros podem sofrer variações, devido aos motivos citados acima, devendo-se portanto manter plena preocupação com o meio ambiente.

Não foi possível detectar por absorção atômica as impurezas contidas nas misturas de fosfogesso e cal, possivelmente deve-se a presença de alguma substância que foi lixiviada em alta concentração, impossibilitando a leitura.

Portanto, deve-se fazer uma análise mais profunda dessas misturas para uma avaliação da adequação do uso da mistura frente às exigências dos códigos brasileiros de proteção ao meio ambiente. 


\section{CONCLUSÕES E SUGESTÕES}

\subsection{CONSIDERAÇÕES INICIAIS}

O objetivo principal deste trabalho foi estudar o comportamento mecânico de misturas constituídas de fosfogesso e cal através da determinação das resistências à compressão simples (RCS), resistência à compressão diametral (RCD), deformabilidade $\left(E_{0}\right)$ e índice de suporte Califórnia (CBR). Posteriormente foi feita uma análise de variâncias dos fatores analisados, como: condição de ensaio (sem e com imersão prévia em água), tempo de cura e teor de cal.

Ressalta-se que todas as conclusões e recomendações apresentadas neste capítulo restringem-se ao universo dos materiais e dos ensaios realizados nesta pesquisa.

\subsection{CONCLUSÕES}

Para os materiais estudados e situações consideradas na pesquisa, as seguintes conclusões podem ser destacadas.

Quantidades crescentes de cal nas misturas de fosfogesso e cal conduzem a menores valores de massa específica seca máxima e maiores valores de umidade ótima.

Para as condições desta pesquisa, pode-se afirmar que a resistência à compressão simples, a rigidez e a resistência à compressão diametral da mistura de fosfogesso e cal são influenciadas pelas variáveis consideradas: condição do ensaio (sem imersão e após imersão em água), tempo de cura e teor de cal. 
O fosfogesso puro é muito suscetível à ação da água. Quando submetido à imersão em água, se desintegrara, não possibilitando a realização dos ensaios, para todos os tempos de cura estudados.

Em todos os casos, a imersão em água dos corpos-de-prova conduz a quedas da resistência à compressão simples, resistência à compressão diametral e do módulo tangente inicial das misturas, ou seja, para todas as condições de estudo, constatam-se quedas de resistência e de rigidez quando são comparados as resistência e a deformabilidade dos corpos-de-prova ensaiados após imersão com daquelas ensaiados sem imersão. No geral a redução de RCS, rigidez e da RCD é em torno de $29 \%, 29 \%$ e 27 , respectivamente, quando se analisa a ação da água. Levando-se a média dos tempos de cura, para cada teor de cal.

Quando se comparam as variações de resistência à compressão simples e à tração por compressão diametral com a imersão, conclui-se que o efeito da água na diminuição da resistência é maior na resistência à compressão simples do que na resistência à tração por compressão diametral, visto que há uma perde em torno de $29 \%$ para os resultados de RCS e de $27 \%$ para os resultados obtidos da $\mathrm{RCD}$.

Comparando-se a variação da coesão correspondente a corpos-deprova ensaiados sem e após imersão, conclui-se que a água provoca diminuição no valor desta variável.

O tempo de cura após a compactação é um fator importante no ganho de resistência à compressão simples, resistência à tração por compressão diametral e rigidez das misturas. As resistências e o módulo de todas as misturas crescem com decorrer do tempo de cura, mas para os ensaios realizados após imersão em água, a importância da cura torna-se mais evidente, pois todos os corpos-de-prova não curados desintegraram-se. A não observação do efeito da cal em corpos-de-prova ensaiados sem cura indica que a ação do aditivo a curto prazo (troca cátion-iônica) não se processa, restando apenas o efeito de cimentação (reação pozolânica da cal com o resíduo), que se dá a longo prazo.

O aumento do teor de cal provoca o acréscimo das resistências e do módulo tangente inicial das misturas. As misturas compostas por $10 \%$ de cal, 
apresentaram em média, resistências e módulo tangente inicial 49\% e 34\% maiores se comparada com os valores obtidos para o fosfogesso puro, respectivamente.

A adição da cal garante a estabilização do fosfogesso frente à ação da água e tem maior efeito na rigidez do que na resistência.

Constatou-se que a resistência à tração por compressão diametral é muito mais sensível ao efeito positivo da adição da cal que a resistência à compressão simples nas misturas com adição do estabilizante. Mostrando que a reação do resíduo a cal contribui muito efetivamente para o ganho de resistência à tração por compressão diametral, indicando que a mesma promove um efeito cimentante considerável, conduzindo a um expressivo aumento da coesão.

Comparando-se os efeitos da cal ao solo com os da sua adição ao fosfogesso, conclui-se que esta última apresentara valores de resistência à compressão simples, em torno de $28 \%$ e resistência à tração por compressão diametral, em torno de $21 \%$ superiores à das misturas de solo cal.

Quando são comparados os desempenhos de misturas compostas por fosfogesso estabilizado com cal e com cimento, este último conduziu a acréscimos de resistência à compressão simples, rigidez e resistência à tração por compressão diametral mais elevados se comparados com as misturas de fosfogesso e cal. Assim, a vantagem do custo menor da cal, aproximadamente $30 \%$ inferior ao do cimento, ficaria minimizado se for considerado apenas $5 \%$ de cal aos 7 dias de cura.

A cal apresenta melhor resultados a curto prazo para a estabilização do fosfogesso frente à ação da água do que o cimento para a RCD.

Para os parâmetros de coesão e ângulo de atrito interno, conclui-se que a adição de cal ao fosfogesso praticamente não altera os parâmetros de resistência, quando se analise os corpos-de-prova ensaiados sem imersão. Entretanto há uma variação do ângulo de atrito interno muito pouco significativa e um crescimento da coesão com o aumento do teor de cal e do tempo de cura. Este fato é devido a ação cimentante da cal, que se processa ao longo do tempo, e que se reflete apenas no valor da coesão. Confirmado assim, que o 
efeito da adição da cal é mais expressivo na resistência à tração por compressão diametral do que na resistência à compressão simples.

Comparando-se os efeitos da adição da cal ao solo com os da sua adição ao fosfogesso, conclui-se que esta última apresenta valores de coesão e de ângulo atrito interno superiores a das misturas solo cal.

Conclui-se que o fosfogesso puro é muito suscetível à ação da água, apresentando CBR igual a 16\%. A adição da cal ao resíduo conduz a valores maiores de CBR. Apesar de não ter sido analisada a influência do tempo de cura, pode-se concluir que a extensão do período em que os corpos-de-prova foram mantidos em câmera úmida antes da imersão em água, possivelmente conduziria a valores mais significativos de CBR.

Foi observado que a adição da cal não produziu expansão da mistura. Entretanto, observou-se que o fosfogesso puro apresentou uma expansão de $0,17 \%$.

É necessária a continuidade da pesquisa para que se conclua favoravelmente pelo uso do fosfogesso estabilizado com cal na área rodoviária.

Finalmente, considerando-se o Procedimento Illinois apresentado no State of the Art 5 - Lime Stabilization (TRB, 1987), que estabelece para misturas solo-cal, as resistências mínimas de 1030 kPa e 690 kPa, valores determinados após 30 dias de cura a $20^{\circ} \mathrm{C}$, respectivamente para a construção de camadas de base e sub-base, observa-se que as misturas de fosfogesso e $5 \%$ e $10 \%$ de cal atendem, respectivamente, o primeiro e o segundo limite, para cura de 28 dias, sem imersão.

\subsection{RECOMENDAÇÕES E SUGESTÕES PARA TRABALHOS FUTUROS}

Avaliação da interação da mistura com o meio ambiente através do estudo da possibilidade de contaminação do lençol freático pelo carregamento de partículas através de bases rodoviárias construídas com o material.

Avaliação da adequação do uso da mistura frente às exigências dos códigos brasileiros de proteção ao meio ambiente. 
Analisar o comportamento resiliente da mistura para os mesmos teores de cal e tempos de cura.

Fazer uma simulação numérica para verificar se os níveis de resistências são adequados para a mistura ser utilizada em camadas de bases e sub bases de pavimentos

Ampliar a pesquisa adicionando solo à mistura de fosfogesso e outros tipos e teores de cal e tempos de cura analisados, variando a energia de compactação.

Avaliar o comportamento das misturas de fosfogesso e cal em campo, através da construção de trechos experimentais e seu monitoramento ao longo do tempo que permita avaliar seu desempenho e problemas construtivos.

Avaliação econômica e ambiental das vantagens e desvantagens da aplicação do fosfogesso na construção rodoviária. 


\section{REFERÊNCIAS BIBLIOGRÁFICAS}

ANDRIEX, P.; BIVERT, B. \& DRON, R. (1978). Utilisation du phosphogypse en assises de chaussée. Bulletin de Liaison des laboratories des ponts et chausses, Le phosphogypse: utilisation dún sous-produit in dustriel en technique routière, número special VII, p. 54-68.

ANTUNES, R. P. N. (1999). Estudo da influência da cal hidratada nas pastas de gesso. Dissertação (Mestrado) apresentada à Escola Politécnica da Universidade de são Paulo para a obtenção do título de mestre em engenharia $-134 p$.

ASSOCIAÇÃO BRASILEIRA DE NORMAS TÉCNICAS (1990) M1: Solos coesivos - determinação da resistência à tração por compressão diametral. Rio de Janeiro.

ASSOCIAÇÃO BRASILEIRA DE NORMAS TÉCNICAS NBR 12770: Solos coesivos - determinação da resistência à compressão simples. Rio de Janeiro.

ASSOCIAÇÃO BRASILEIRA DE NORMAS TÉCNICAS (1992) NBR 7175: Cal hidratada para argamassas. Rio de Janeiro.

ASSOCIAÇÃO BRASILEIRA DE NORMAS TÉCNICAS. NBR 10004 Resíduos sólidos - classificação, 2004. p.01 - 71.

ASSOCIAÇÃO BRASILEIRA DE NORMAS TÉCNICAS. NBR 10005 Lixiviação de resíduos - procedimento, 2004. p. $01-16$.

ASSOCIAÇÃO BRASILEIRA DE NORMAS TÉCNICAS. NBR 10006 Solubilização de resíduos - procedimento, 2004. p. 01 - 03.

ASSOCIAÇÃO BRASILEIRA DE NORMAS TÉCNICAS. NBR 10007 Amostragem de resíduos sólidos - procedimento, 2004. p.01 - 21. 
ABREU, R. T. (1992). Usos industriais para o fosfogesso. In: SEMINÁRIO SOBRE O USO DO GESSO NA AGRICULTURA, 2. Uberaba, ./ Anais/, São Paulo, IBRAFOS, 1992, P 369-97.

BARBOSA, D. A. (1980). Rochas fosfáticas brasileiras. Tecnologia de fertilizantes Fosfatados. Centro de Estudos de Fertilizantes. Instituto de Pesquisas Tecnológicas do Estado de São Paulo - IPT, v. 9, 1980. p. 95-122.

BARNETT, S.; ADAM, C.; JACKSON, A.; HYWELL-EVANS, P. (1999). Identification and characterization of thaumasite by XRPD techniques. Cement and Concrete Composites, v. 21, p. 123-128.

BARTL, P. E. \& ALBUQUERQUE P. C. W. (1992). Alternativas para reciclagem industrial do fosfogesso. Anais do II seminário sobre o uso do gesso na agricultura, 24, 25 e 26 de março — Instituto Brasileiro de Fosfato - IBRAFOS, Uberaba, p. 67-81.

BASMA A. A.; TUNCER R. E. (1991). Effect of lime on volume change and compressibility of expansive clays. In: Transportation Research Record. 1295. 1991, p 52-61.

BERISH, C. W. (1990). Potencial environmental hazards of phosphogypsum storage in central Florida. In: Proceedings of the Third International Symposium on Phosphogypsum, Orlando, Florida, December, 1990. V. I, p. 1-29.

BHUIYAN, J.U.; DALLAS, N. L.; GRAVES, R. E. (1995). Evaluation of calcareous base course materials stabilized with low percentage of lime in South Texas. In: Transportation Research Board, n. 1486,1995, p.77-87.

CARMO, A. J. B. (1994). Tecnologia e competitividade na indústria brasileira de fertilizantes fosfatados. Tese apresentada à faculdade de Economia e Administração da Universidade de São Paulo para obtenção do título de Doutor em Economia. São Paulo, 1994. 252 p.

CARPINETTI, L. C. R. (2003). Planejamento e análise de experimentos. Publicações da Escola de Engenharia de São Carlos, Universidade de São Paulo, Departamento de Engenharia de Produção. São Carlos, 2003. 223p. 
CASTRO, E., LUIS,A. S. (1974). O solo-cal na pavimentação de estradas e aeródromos. In: Revista da Sociedade Portuguesa de Geotecnia, $n^{\circ} 10$, 1974.

CHANG, W. F. e MANTELL, M. I. (1990). Enineering propertties and construction applications of phosphogypsum. Phosphate Research Institute, University of Miami, Coral Gables, Florida, 203p.

CHIN, D. A. (1988). The impact of a phosphogypsum roadway on local groundwater quality - a case study. In: Proceedings of the Second International Symposium on Phosphogypsum, Miami, Florida, December, 1986. V. I, p. 35-60.

DAMASCENO, E. C. e LIMA, J. R. B. (1994). Aproveitamento de resíduos da indústria de mineração: o fosfogesso gerado pela solubilização de concentrados fosfático. III Congresso Ítalo Brasiliano di ingegneria mineraria. Eolizioni Pei SrI - viale Verona, 26-27 settembre 1994.

DANTAS H. S. (1970). Estabilização de solos com emprego da cal - Tentativa de espacificação de construção. Instituto de pesquisa rodoviária, publicação 462, 1970, Rio de Janeiro.

DEPARTAMENTO DE ESTRADAS DE RODAGEM DO ESTADO DE SÃO PAULO (1961). DER/SP M 4 - Determinação do limite de liquiez de solos. São Paulo.

DEPARTAMENTO DE ESTRADAS DE RODAGEM DO ESTADO DE SÃO PAULO (1961). DER/SP M 5 - Determinação do limite e índice de plasticidade de solos. São Paulo.

DEPARTAMENTO DE ESTRADAS DE RODAGEM DO ESTADO DE SÃO PAULO (1961). DER/SP M 6 - Análise granulométrica de solos por peneiração e sedimentação (processo do densímetro). São Paulo.

DEPARTAMENTO DE ESTRADAS E RODAGEM DO ESTADO DE SÃO PAULO (1961). DER/SP M 13 - Ensaio de compactação de solos. São Paulo. 
DEPARTAMENTO DE ESTRADAS E RODAGEM DO ESTADO DE SÃO PAULO (1991). DER/SP ES 301 - Sub-base estabilizada granulometricamente. São Paulo.

DEPARTAMENTO DE ESTRADAS E RODAGEM DO ESTADO DE SÃO PAULO (1991). DER/SP ES 303 - Base estabilizada granulometricamente. São Paulo.

DIAS, A. M. N. (1994). Gesso de construção: caracterização do pó, pasta e argamassa e aplicação como revestimento interno. São Paulo, 1994. Dissertação (Mestrado) - Escola politécnica da Universidade de São Paulo.

DNPM, 1976. Departamento Nacional da Produção Mineral. Perfil analítico dos fertilizantes fosfatados. Boletim n. 39, por José Maria Gonçalves de Lima. Brasília, Ministério das Minas e Energia, 55 p.

DNPM, 1991. Departamento Nacional da Produção Mineral. Anuário mineral brasileiro 1990. Ministério das Minas e Energia. Brasília.

DNPM, 1993. Departamento Nacional da Produção Mineral. Sumário mineral 1992. Ministério das Minas e Energia. Brasília.

DRUMM, E, C.; Y. BOATENG-POKU e T. J. PIERCE. (1990). Estimation of subgrade resilient modulus from standard tests. Journal of Geotechnical Engineering, v. 116, n. 5, p. 774-789.

ERDEM, E.; ÖLMEZ, H. (1989). The effects of phosphogypsum on the setting and mechanical properties of portland-cement and trass cement. Cement and Concrete Research., n. 19, p. 377-384.

FERGUSON, F. (1988). Phosphogypsum - Overview. In: Proceedings of the Second International Symposium on Phosphogypsum, Miami, Florida, v. 1, p. $117-130$.

FOSFÉRTIL, Fertilizantes Fosfatados S. A.; s.d. Tecnologia da fabricação do ácido fosfórico. Uberaba, Minas Gerais, 38 p.

FOXWORTHY, P. T.; OTT, E.; SEALS, R. K. (1994). Utilization phosphogypysum-based slag aggregate in Portland cement concrete mixtures. Transportations Research Board. n. 1437, 1994, p. 19-26. 
FOXWORTHY, p. t.; NADIMPALLI, R. S.; SEALS, R. K. (1996) Phosphogypsum slag aggregate-based asphaltic concrete mixes. Journal of Transportation Engineering, v. 122, n. 4, July/August, 1996, p. 300-307.

FREITAS, J. B. (1992). A disposição do fosfogesso e seus impactos ambientais. IBRAFOS - Instituto brasileiro do fosfato, 24, 25 e 26 de março de 1992. 413 p.

GADALLA, A. M.; SAYLAK, D. e LINDNER, A. L. (1994). Comparison of strength development in waste industrial gypsum produced by the hemihydrate and dihydrate processes. Journal of the American Ceramic Society, v. 73, n. 8, p. $2255-2260$.

GARCIA-DIAZ, A.; PHILLIPS, D. T. (1995). Principles of experimental desing and analysis. Chapman \& Hall. Londres.

GERRITY, D. M.; METCALF, J. B. e SEALS, R. K. (1994). Estimating the design life of a prototype cement-stabilized phosphogypsum pavement. Transportation Research Record, n. 1440, p. 32-36.

GHAFOORI, N.; CHANG, W. F. (1993). Investigation of phosphate mining waste for construction materials. Journal of materials in Civil Engineering, v. 5 , n. 2, p. 249-264.

GOERS, W. E. (1980). Nissan Hemi Phosphogypsum. In: Proceedings International Symposium on Phosphogypsum, Lake Buena Vista, Florida, Nov, 1980, v.1, p. 36-52.

GREGORY, C. A.; SAYLAK, D.; LEDBETTER, W. B. (1984). The use of byproduct phosphogypsum for road bases and subbases. Transportation Research Record, 998, p. 47-52.

GUERRA, A. T. (1979). Dicionário geológico-geomorfológico. IBGE, 5a edição, Revisada atualizada por Ignez Amélia Leal Teixeira e Antônio José Teixeira Guerra. Rio de janeiro. Secretaria de Planejamento da Presidência da República.

GUMARÃES, J. A. P.(1971) Estabilização de solos - Nova e importante aplicação da cal - Seus conceitos e suas vantagens. Boletim n I. São Paulo: ABCP, 1971. 
GUTTI, C. S.; ROY, A.; METCALF, J. B.; SEALS, R. K. (1996). The influence of admixtures on the strength and linear expansion of cement-stabilized phosphogypsum. Cement and Concrete Research, v. 26, n. 7, p. 1083-1094.

HINCAPIÉ, A. M.; OliVEIRA, C. T. A.; CinCOTTO, M. A.; SELMO, S. M. (1996a). Revestimento de gesso I. Téchne, n21. mar/abr, p. 44-47, 1996a.

HINCAPIÉ, A. M.; OLIVEIRA, C.T.A.; CINCOTTO, M. A.; SELMO, S. M. (1996b). revestimento de gesso II. Téchne, n22. mai/jun, p. 49-52, 1996b.

INSTITUTO DE PESQUISAS TECNOLÓGICAS (2000ª). Análise química de amostras de fosfogesso di-hidratado. Relatório de ensaio n. 873.218. Laboratório de Química de Materiais, São Paulo, 3p.

JAMES, A. C. (1996). Assessment of doses and risks from uses of waste product phosphogypsum in agriculture and road constuction. Presented at the Phosphogypsum Fact-Finding Forum, Tallahassee, Florida, December 7, 1995.

JOHNSON, J. R.; TRAUB, R. J. (1996). Polk county experimental road. In: Laboratories/Florida Institute of Phosphate Research. (Final Report).

KOBAYASHI, A. R. K. (2000). Avaliação o tipo de cimento na expansibilidade de misturas de fosfogesso e cimento. Dissertação (Mestrado) - São Carlos. Escola de Engenharia de São Carlos, Universidade de São Paulo. 113p.

KOULOHERIS, A. P. (1980). Chemical nature of phosphogypsum as produced by various wet process phosphoric acid processes. In: Proceedings of the International Symposium on Phosphogypsum, Lake Buena Vista, Florida, 57 November, 1980. p. 7-34.

LAHTINEN, P. (2001). Fly ash mixtures as flexible structural materials for lowvolume roads. FINNRA reports 70/2001. Helsinque, Filândia. Disponível em http://lib.hut.fi/diss/2001/isbn9512257076/isbn9512257076.pdf. Acesso em: março 2004.

LEGAL, C. C. E MYRICK, O. D., Jr. (1968). History and satatus of phosphoric acid. Phosphoric Acid, v.1, part 1, New York. 
LIMA, R. M. F. (1989). Novos coletores na flotação do minério fosfático de Tapira, Minas Gerais. Dissertação de (Mestrado). Universidade Federal de Minas Gerais, 120 p.

LOVATO, R. S.; NÚÑEZ, W. P.; CERATTI, J. A.; SECCHII, F.; SILVA, S. F. (2004). Registro histórico da estabilização de solos lateríticos com cal: o trecho experimental na BR-377. Artigo publicado na revista Estradas ANO 4 Novembro de 2004 n 7.p 38-44.

MACAMBIRA, I. Q. (2002). Comportamento hidráulico de alguns solos lateríticos para uso como barreira impermeável. Dissertação de (Mestrado). Escola de Engenharia de São Carlos, USP. São Carlos - SP, 128p.

MACCARINI, M. (1991). Propriedades física, química e mecânica do fosfogesso da indústria carboquímica catarinense. In: Simpósio sobre barragens de rejeitos e disposição de resíduos, Rio de janeiro, p. 147-157.

MANGIN, S. (1978). Généralités. Lê phosphogypse - utilization d'un sousproduit industriel en technique routière. Bulletin de Liaison des Laboratoires des Ponts et Chaussées, número. spécial 7, p. 7-13.

MENDONÇA A. A., CARDOSO D. D., BUENO, B. D., FONTES M. P. F. (1997). Efeito da temperatura de cura na resistência à compressão simples de um latosolo e de um solo saprolítico estabilizados com cal. $1^{\circ}$ Simpósio internacional de pavimentação de rodovias de baixo volume de tráfego. Rio de Janeiro. Outubro.

MENDONÇA A. A., CARDOSO D. D., FONTES M. P. F. (1997). Resistência à compressão simples e a compressão diametral de misturas de solo cal: estudo dirigido a dois solos típicos de Viçosa. $1^{\circ}$ Simpósio internacional de pavimentação de rodovias de baixo volume de tráfego. Rio de Janeiro. Outubro.

MOHAMMAD, M. S.; RAMI, H. H.; AHMAD, M. A. (1999). Potential use of phosphogypsum in concrete. Cement and Concrete Research. N. 29, May, 1999, p. 1419-1425.

MOLINA, C. E. C (2004). Estudo do comportamento mecânico de misturas de resíduo da fabricação de papel e solo para utilização na construção rodoviária. 
Dissertação (mestrado). São Carlos. Escola de Engenharia de São Carlos, Universidade de São Paulo.110p.

NANNI, A. e CHANG, W. F. (1989). Phosphogypsum-based roller compacted concrete. Concrete International: design and Construction. V. 11, $\mathrm{n}^{\circ} 11$, Nov 1989, p. 48-53.

NOLHIER, M. (1986). Contruire en plâtre. Paris, L'harmattan, (1973).

ONG, S.; METCALF, J. B.; SEALS, R. K. e TAHA, R. (1994). Unconfined compressive strength of various cement-stabilized phosphogypsum mixes. Trasnportation Research Record, n. 1424, p.20-24.

ORTIZ, J. A. (1997). Estudo de misturas de solo e fosfogesso com a sua utilização em rodovias. São Carlos. 179 p. Dissertação (Mestrado) - Escola de Engenharia de São Carlos, Universidade de São Paulo.

PARENTE, E., P. (2002). Avaliação do comportamento mecânico das misturas de solo-cimento e fosfogesso e cimento para uso na construção rodoviária. Dissertação (Mestrado) - São Carlos. Escola de Engenharia de São Carlos, Universidade de São Paulo.138p.

PARREIRA A. B. (2001). Materiais não convencionais em pavimentação: O estudo do fosfogesso. Texto Sistematizado (Livre-Docência). São Carlos São Paulo. Escola de Engenharia de São Carlos - EESC/USP. 146p.

PEREIRA, E. B. (1973). Perfil analítico da gipsita. Ministério das Minas e energia - Departamento Nacional de Produção Mineral. Boletim nº 15, 1973. POVINELLI, J. (1987). Ação dos metais pesados nos processos biológicos de tratamento de águas residuárias. São Carlos, 1987. Tese (Livre Docência em Engenharia/Hidráulica e Saneamento) - Escola de Engenharia de São Carlos, Universidade de São Paulo.

ROESSELER, C. E. (1990). Radon emation from roads constructed with phosphogypsum aggregates. In: Proceedings of the Third International Symposium on Phosphogypsum, Orlando, Florida, December, 1990. p. 3043.

ROSA, R. (1997). Exposição potencial à radiação natural, no interior de residências, devido ao uso de fosfogesso na indústria da construção civil. 
IBRAFOS - Instituto brasileiro do fosfato. Centro de ciências e saúde. Instituto de Biofísica Carlos Chagas Filho. p. 122.

RUIZ, C. L. (1964). Presentación y comentario sobre los diagramas Shell 1963 para el diseño de pavimentos flexibles. DVBA, Ministerio de Obras Publicas, La Plata Argentina.

SANTOS, V. A. (1998). Fundamentos sobre processos de produção de gesso a partir da desidratação térmica da gipsita. Recife, PEDITEC - ITEP DQIUNICAP - DEQ/UFPE, 1998.

SAYLAK, D.; TAHA, R. e LITTLE, D. N. (1988). Recommended procedure for sample preparation and testing stabilized gypsum mixtures. In: Proceedings of the Second International symposium on Phosphogypsum, Miami, Florida, December, 1988, v. 9, 1980. p. 31-52.

SELMO, S. M. S. (1996). Convênio de pesquisa para avaliação do fosfohemidratado SERRANA como aglomerante único em pastas de revestimento de paredes e tetos de edificações. São Paulo, EPUSP, 1996 (Relatório técnico, 10.100. Relatório no $3 / 4$ - Resultados finais da fase I quanto aos ensaios químicos, físicos e mec6anicos de fosfogesso $\mathrm{HH}$ ).

SELMO, S. M. S. et al. (1997). Microestrutura de pastas de gesso de construção: efeito da relação água gesso e de alguns aditivos, por microscopia eletrônica de varredura In: Encontro nacional de gesso na construção civil, I. Olinda, 1997. Anais, ITEP, Recife, 1997, p. 79-86.

SELMO, S. M. S. (1997). Aço carbono em pastas de gesso de construção Estimativas de taxas de corrosão por impedância e por método gravimétrico conjugado à análise de imagem. São Paulo 1997. Tese (Doutorado) - Escola Politécnica da Universidade de São Paulo.

SERVIÇO DE APOIO À PEQUENA EMPRESA NO ESTADO DE PERNAMBUCO - SEBRAE (1996). Diagnóstico das atividades econômicas do pólo gesseiro do Araripe. Recife, secretaria de ciência, tecnologia e meio ambiente do estado de Pernambuco, 1996. 
SILVA, A. F., Jr. (1980). Rochas fosfáticas brasileiras. Tecnologia de Fertilizantes Fosfatados. Centro de Estudos de Fertilizantes - Instituto de Pesquisas Tecnológicas do Estado de São Paulo - IPT, v. 9, p. 31-52.

SILVA, L. H. C. (1997). Aspectos econômico-ambientais do uso do fosfogesso na agricultura. Instituto brasileiro do fosfato - IBRAFO, Rio de Janeiro - RJ, 1997. $127 \mathrm{p}$.

SILVESTRE O., B., Jr. (2002). Fosfogesso estabilizado com cimento para aplicação na construção rodoviária - A influência do tipo de cimento na resistência e deformabilidade da mistura. Dissertação (Mestrado) - São Carlos. Escola de Engenharia de São Carlos, Universidade de São Paulo.163p. SINGH, MANJIT; GARG, MRIDUL; REHSI, S.S. (1990). Durability of phosphogypsum based water-resistant anhydrite binder. Cement and Concrete Research. V 20 n. 2 Mar 1990 p. 271-276.

SUMÁRIO MINERAL (1996). República Federativa do Brasil, Ministério da Infra - estrutura, Secretaria Nacional de Minas e Metalurgia e Departamento Nacional de Produção Mineral, Brasileira., 1996.

TAHA, R. e SEALS, R. (1991). Phosphogypsum leterature review. (Report $\mathrm{n}$. I-90-4).

TAHA, R.; SEALS, R. K. (1991a). Expansion test specimens - results and recommendations. Report n. 1-91-4D. Institute for Recyclable Materials, College of Engineering, Louisiana State University, Baton Rouge, 61p.

TAHA, R.; SEALS, R. K. (1992). Engineering properties of phosphogypsumbased slag aggregate. Transportation Research Record, n. 1345, p. 106-112.

TAHA, R.; SEALS, R. K.; TITTLEBAUM, M. E SAYLAK, D. (1995). Environmental characteristics of by-product gypsum. Transportation Research Record, n. 1486, p. 21-26.

TAHA, R; SEALS, R. K.; TITTLEBAUM, M e SAYLAK, D. (1995). Environmental characteristics of by-product gypsum. Transportation Research Record, n. 1486, p. 21-26.

TAKEDA, M. C. (1988). Avaliação das propriedades mecânicas de misturas de fosfogesso e cimento para uso na construção rodoviária. Dissertação 
(Mestrado) - São Carlos. Escola de Engenharia de São Carlos, Universidade de São Paulo. 164p.

THOMPSON, M. R. (1966). Lime reactive of Illinois Soils. Journal of the Soil Mechanics and Foundations Division. ASCE, v.92, p67-92.

TitTlebaum, M. E.; THIMMEgOWDA, H.; SEALS, R. K. e JONES, S. C. (1995). Leachate generation from raw and cement satabilized phosphogypsum. Transportation Research Record, n. 1486, 0. 27-34.

TREFLER, M. WU, e MEDORA, R. P. (1988). Radon emanation from building materials. In: Proceedings of the second International Symposium on Phosphogypsum, Miami, Florida, December, 1986. V. I, p.25-34.

TRICHÊS, G.; MACCARINI M. (1988). Misturas Fosfogesso/Cinza para Construção Rodoviária - estudos Preliminares. 23ํㅡㄹ REUNIÃO ANUAL DE PAVIMENTAÇÃO - ABPV, Florianópolis, p. 311-329.

TUNCER E. R., BAMA A. A. (1991). Stregth and stress-strain characteristics of lime-treated cohesive soil. In: Transportation Research Record. 1295., 1991, pp 70-79.

VAIDERGORIN, E. I. (1988). Características dos cimentos portland: uma abordagem química. In: TECNOLOGIA DE EDIFICAÇÕES, ed. Pini. São Paulo. P. 19-22.

VALERY, Jr. W. (1991). Reciclagem do fosfogesso, um rejeito da fabricação de ácido fosfórico. Reciclagem de rejeitos industriais. Resumo dos trabalhos vencedores do prêmio Jovens cientista 1990. Priscila Benor "et al". Fundação Roberto Marinho. CNPQ grupo Verdau, 1991 - Rio de Janeiro $112 \mathrm{p}$.

WALPOLE, R. E., MYERS R. H., MYERS, S. L. (1999). Probabilidade y estadística para ingenieros, Sexta edição Prentice may Inc.

WALSH, P. J. (1990). Randon daughter risks associated with phosphogypsum. In: Proceedings of the Third International Symposium on Phosphogypsum, Orlando, Florida, December, 1990. p. 44-63. 


\section{- ANEXO A - RESULTADOS DOS ENSAIOS RESISTÊNCIA À COMPRESSÃO SIMPLES DAS MISTURAS DE FOSFOGESSO E CAL SEM E APÓS IMERSÃO EM ÁGUA}


TABELA A.1 - Valores de resistência à compressão simples para corpos de prova ensaiados sem e após imersão em água ( $\mathrm{kPa})$

\begin{tabular}{|c|c|c|c|c|c|c|c|c|c|c|c|c|}
\hline \multirow{2}{*}{ Tempo de cura } & \multirow{2}{*}{ Teor de resíduo (\%) } & \multirow{2}{*}{ Teor de cal (\%) } & \multicolumn{5}{|c|}{ Sem imersão } & \multicolumn{5}{|c|}{ Após imersão } \\
\hline & & & CP1 & CP2 & CP3 & CP4 & média & CP1 & CP2 & CP3 & CP4 & média \\
\hline \multirow{5}{*}{ imediato } & 100 & 0 & 395 & 530 & 487 & 522 & 484 & nd & nd & nd & nd & nd \\
\hline & 97 & 3 & 473 & 479 & 471 & 470 & 473 & nd & nd & nd & nd & nd \\
\hline & 95 & 5 & 529 & 495 & 522 & 493 & 510 & nd & nd & nd & nd & nd \\
\hline & 93 & 7 & 585 & 659 & 538 & 624 & 601 & nd & nd & nd & nd & nd \\
\hline & 90 & 10 & 684 & 695 & 627 & 715 & 680 & nd & nd & nd & nd & nd \\
\hline \multirow{5}{*}{3 dias } & 100 & 0 & 490 & 542 & 534 & 550 & 529 & $\mathrm{nd}$ & nd & $\mathrm{nd}$ & nd & $\mathrm{nd}$ \\
\hline & 97 & 3 & 601 & 533 & 624 & 530 & 572 & 302 & 342 & 349 & 303 & 324 \\
\hline & 95 & 5 & 603 & 612 & 579 & 583 & 594 & 338 & 323 & 353 & 384 & 349 \\
\hline & 93 & 7 & 688 & 693 & 646 & 676 & 676 & 554 & 513 & 423 & 412 & 475 \\
\hline & 90 & 10 & 746 & 695 & 754 & 665 & 715 & 575 & 415 & 614 & 419 & 506 \\
\hline \multirow{5}{*}{7 dias } & 100 & 0 & 544 & 615 & 554 & 561 & 568 & nd & nd & nd & nd & nd \\
\hline & 97 & 3 & 518 & 644 & 585 & 542 & 572 & 376 & 359 & 358 & 363 & 364 \\
\hline & 95 & 5 & 613 & 606 & 606 & 602 & 607 & 357 & 395 & 504 & 350 & 402 \\
\hline & 93 & 7 & 738 & 715 & 712 & 710 & 719 & 450 & 565 & 619 & 497 & 533 \\
\hline & 90 & 10 & 850 & 854 & 846 & 822 & 843 & 627 & 616 & 630 & 653 & 631 \\
\hline \multirow{5}{*}{28 dias } & 100 & 0 & 530 & 580 & 668 & 550 & 582 & nd & nd & nd & nd & nd \\
\hline & 97 & 3 & 686 & 790 & 623 & 691 & 698 & 559 & 557 & 537 & 531 & 546 \\
\hline & 95 & 5 & 810 & 772 & 799 & 795 & 794 & 597 & 618 & 574 & 622 & 603 \\
\hline & 93 & 7 & 899 & 858 & 851 & 856 & 866 & 778 & 712 & 682 & 698 & 718 \\
\hline & 90 & 10 & 1026 & 1022 & 1013 & 1017 & 1020 & 833 & 836 & 855 & 853 & 844 \\
\hline
\end{tabular}

*nd - não determinado 
- ANEXO B -

VALORES DE MÓDULO TANGENTE INICIAL $\left(E_{0}\right)$ PARA AS MISTURAS DE FOSFOGESSO E CAL ENSAIADAS SEM E APÓS IMERSÃO 
TABELA B.1 - Valores de módulo tangente inicial $\left(E_{0}\right)$ para corpos de prova ensaiados sem e com imersão em água ( $\mathrm{kPa})$

\begin{tabular}{|c|c|c|c|c|c|c|c|c|c|c|c|c|}
\hline \multirow{2}{*}{ Tempo de cura } & \multirow{2}{*}{ (\%) de resíduo } & \multirow{2}{*}{ cal (\%) } & \multicolumn{5}{|c|}{ Sem imersão } & \multicolumn{5}{|c|}{ Após imersão } \\
\hline & & & CP1 & CP2 & CP3 & CP4 & média & CP1 & CP2 & CP3 & CP4 & média \\
\hline \multirow{5}{*}{ imediato } & 100 & 0 & 15000 & 18000 & 17000 & 17000 & 16750 & nd & nd & nd & nd & nd \\
\hline & 97 & 3 & 18000 & 19000 & 20000 & 21000 & 19500 & nd & nd & nd & nd & nd \\
\hline & 95 & 5 & 19000 & 19000 & 21000 & 21000 & 20000 & nd & nd & nd & nd & nd \\
\hline & 93 & 7 & 23000 & 18000 & 18000 & 24000 & 20750 & nd & nd & nd & nd & nd \\
\hline & 90 & 10 & 23000 & 26000 & 17000 & 18000 & 21000 & nd & nd & nd & nd & nd \\
\hline \multirow{5}{*}{3 dias } & 100 & 0 & 38000 & 39000 & 38000 & 38000 & 38250 & nd & nd & nd & nd & nd \\
\hline & 97 & 3 & 24000 & 54000 & 51000 & 48000 & 44250 & 31000 & 13000 & 21000 & 31000 & 24000 \\
\hline & 95 & 5 & 50000 & 66000 & 57000 & 53000 & 56500 & 22000 & 31000 & 28000 & 33000 & 28500 \\
\hline & 93 & 7 & 57000 & 63000 & 54000 & 62000 & 59000 & 31000 & 31000 & 55000 & 43000 & 40000 \\
\hline & 90 & 10 & 64000 & 51000 & 67000 & 60000 & 60500 & 25000 & 44000 & 40000 & 54000 & 40750 \\
\hline \multirow{5}{*}{7 dias } & 100 & 0 & 61000 & 49000 & 66000 & 50000 & 56500 & nd & nd & nd & nd & nd \\
\hline & 97 & 3 & 35000 & 67000 & 72000 & 72000 & 61500 & 32000 & 34000 & 35000 & 37000 & 34500 \\
\hline & 95 & 5 & 81000 & 79000 & 45000 & 81000 & 71500 & 46000 & 34000 & 38000 & 37000 & 38750 \\
\hline & 93 & 7 & 69000 & 86000 & 75000 & 89000 & 79750 & 53000 & 57000 & 56000 & 59000 & 56250 \\
\hline & 90 & 10 & 93000 & 47000 & 76000 & 92000 & 77000 & 80000 & 84000 & 79000 & 82000 & 81250 \\
\hline \multirow{5}{*}{28 dias } & 100 & 0 & 23000 & 36000 & 67000 & 41000 & 41750 & nd & nd & nd & nd & nd \\
\hline & 97 & 3 & 101000 & 66000 & 82000 & 99000 & 87000 & 83000 & 78000 & 87000 & 79000 & 81750 \\
\hline & 95 & 5 & 106000 & 104000 & 69000 & 101000 & 95000 & 101000 & 89000 & 99000 & 87000 & 94000 \\
\hline & 93 & 7 & 123000 & 108000 & 95000 & 113000 & 109750 & 107000 & 100000 & 110000 & 98000 & 103750 \\
\hline & 90 & 10 & 101000 & 156000 & 141000 & 156000 & 138500 & 119000 & 129000 & 127000 & 113000 & 122000 \\
\hline
\end{tabular}

*nd-nãodeterminado 
- ANEXO C -

RESULTADOS DOS ENSAIOS RESISTÊNCIA À TRAÇÃO POR COMPRESSÃO DIAMETRAL DAS MISTURAS DE FOSFOGESSO E CAL ENSAIADAS SEM E APÓS IMERSÃO EM ÁGUA 
TABELA C.1 - Valores dos resultados dos ensaios de resistência à tração por compressão diametral para corpos de prova ensaiados sem e após imersão em água ( $\mathrm{kPa})$

\begin{tabular}{|c|c|c|c|c|c|c|c|c|c|c|c|c|}
\hline \multirow{2}{*}{ Tempo de cura } & \multirow{2}{*}{ Teor de resíduo (\%) } & \multirow{2}{*}{ Teor de cal (\%) } & \multicolumn{5}{|c|}{ Sem imersão } & \multicolumn{5}{|c|}{ Após imersão } \\
\hline & & & CP1 & CP2 & CP3 & CP4 & média & CP1 & CP2 & CP3 & CP4 & média \\
\hline \multirow{5}{*}{ imediato } & 100 & 0 & 29 & 29 & 29 & 29 & 29 & nd & nd & nd & nd & nd \\
\hline & 97 & 3 & 30 & 29 & 24 & 36 & 30 & nd & nd & nd & nd & $\mathrm{Nd}$ \\
\hline & 95 & 5 & 34 & 29 & 32 & 34 & 32 & nd & nd & nd & nd & $\mathrm{Nd}$ \\
\hline & 93 & 7 & 35 & 37 & 40 & 40 & 38 & nd & nd & nd & nd & $\mathrm{Nd}$ \\
\hline & 90 & 10 & 40 & 45 & 46 & 43 & 44 & nd & nd & nd & nd & $\mathrm{Nd}$ \\
\hline \multirow{5}{*}{3 dias } & 100 & 0 & 38 & 35 & 40 & 40 & 38 & nd & nd & nd & nd & $\mathrm{Nd}$ \\
\hline & 97 & 3 & 41 & 41 & 40 & 42 & 41 & 28 & 28 & 29 & 17 & 26 \\
\hline & 95 & 5 & 46 & 40 & 40 & 43 & 42 & 29 & 24 & 29 & 29 & 28 \\
\hline & 93 & 7 & 47 & 46 & 46 & 46 & 46 & 34 & 35 & 34 & 34 & 34 \\
\hline & 90 & 10 & 55 & 57 & 51 & 57 & 55 & 46 & 46 & 45 & 45 & 46 \\
\hline \multirow{5}{*}{7 dias } & 100 & 0 & 46 & 41 & 39 & 40 & 41 & nd & nd & nd & nd & $\mathrm{Nd}$ \\
\hline & 97 & 3 & 46 & 52 & 52 & 40 & 47 & 35 & 29 & 29 & 32 & 31 \\
\hline & 95 & 5 & 49 & 57 & 57 & 49 & 53 & 31 & 29 & 32 & 33 & 32 \\
\hline & 93 & 7 & 66 & 58 & 54 & 57 & 59 & 35 & 35 & 29 & 40 & 34 \\
\hline & 90 & 10 & 69 & 63 & 63 & 57 & 63 & 51 & 51 & 51 & 51 & 51 \\
\hline \multirow{5}{*}{28 dias } & 100 & 0 & 58 & 52 & 46 & 49 & 52 & nd & nd & nd & nd & $\mathrm{Nd}$ \\
\hline & 97 & 3 & 77 & 74 & 71 & 65 & 72 & 57 & 56 & 62 & 59 & 59 \\
\hline & 95 & 5 & 83 & 82 & 82 & 82 & 82 & 65 & 71 & 66 & 69 & 68 \\
\hline & 93 & 7 & 94 & 85 & 97 & 94 & 92 & 69 & 74 & 80 & 71 & 73 \\
\hline & 90 & 10 & 108 & 113 & 112 & 114 & 112 & 83 & 82 & 85 & 94 & 86 \\
\hline
\end{tabular}

*nd - não determinado 
- ANEXO D RESULTADOS DOS ENSAIOS DE CBR DAS MISTURAS DE FOSFOGESSOE CAL 
Tabela D.1 - CBR e Expansão das misturas de fosfogesso e cal aos 11 dias de cura

\begin{tabular}{|c|c|c|c|c|c|}
\hline $\begin{array}{c}\text { Teor de } \\
\text { resíduo (\%) }\end{array}$ & $\begin{array}{c}\text { Teor de cal } \\
(\%)\end{array}$ & CBR (\%) & $\begin{array}{c}\text { Expansão } \\
(\%)\end{array}$ & $\begin{array}{c}\text { Grau de } \\
\text { compactação } \\
(\%)\end{array}$ & w。 (\%) \\
\hline 100 & 0 & 16 & 0,17 & 83 & 12,4 \\
\hline 97 & 3 & 54 & 0 & 95 & 16,4 \\
\hline 95 & 5 & 56 & 0 & 94 & 16,9 \\
\hline 93 & 7 & 65 & 0 & 94 & 15,7 \\
\hline 90 & 10 & 71 & 0 & 94 & 15 \\
\hline
\end{tabular}


- ANEXO E -

APLICAÇÃO DO MÉTODO DE GRUBBS

PARA DETECÇÃO DE OUTLIERS 


\begin{tabular}{|c|c|c|c|c|c|c|c|c|c|c|c|c|c|c|}
\hline \multirow{2}{*}{$\begin{array}{c}\begin{array}{c}\text { cura } \\
\text { (dias) }\end{array} \\
\end{array}$} & \multirow{2}{*}{$\begin{array}{l}\text { cal } \\
(\%) \\
\end{array}$} & \multirow{2}{*}{$\begin{array}{c}\text { resíduo } \\
(\%) \\
\end{array}$} & \multicolumn{4}{|c|}{ corpo de prova } & \multirow{2}{*}{$\begin{array}{l}\text { média } \\
\text { (KPa) } \\
\end{array}$} & \multirow{2}{*}{$\begin{array}{l}\text { desvio } \\
\text { padrão }\end{array}$} & \multirow{2}{*}{$\begin{array}{c}\text { G } \\
\text { Maior }\end{array}$} & \multirow{2}{*}{$\begin{array}{c}\text { G } \\
\text { Menor }\end{array}$} & \multirow{2}{*}{$\begin{array}{c}\text { Gcrítico } \\
95 \% \\
\end{array}$} & \multirow{2}{*}{$\begin{array}{c}Y \\
\text { máx }\end{array}$} & \multirow{2}{*}{$\begin{array}{c}\text { Y } \\
\text { Mín }\end{array}$} & \multirow{2}{*}{$\begin{array}{c}\text { Média } \\
\text { adotada }\end{array}$} \\
\hline & & & 1 & 2 & 3 & 4 & & & & & & & & \\
\hline 0 & 0 & 100 & 395 & 530 & 487 & 523 & 484 & 62,16 & 1,43 & 0,75 & 1,15 & 555,4 & 412,4 & 530 \\
\hline 0 & 3 & 97 & 473 & 479 & 471 & 470 & 473 & 3,84 & 0,74 & 1,44 & 1,15 & 477,6 & 468,8 & 473 \\
\hline 0 & 5 & 95 & 529 & 495 & 522 & 493 & 510 & 18,23 & 0,91 & 1,05 & 1,15 & 531,0 & 489,0 & 510 \\
\hline 0 & 7 & 93 & 585 & 659 & 538 & 624 & 601 & 52,12 & 1,22 & 1,11 & 1,15 & 661,4 & 541,5 & 659 \\
\hline 0 & 10 & 90 & 684 & 695 & 627 & 715 & 680 & 37,74 & 1,41 & 0,91 & 1,15 & 723,6 & 636,8 & 715 \\
\hline 3 & 0 & 100 & 490 & 542 & 534 & 550 & 529 & 26,93 & 1,45 & 0,79 & 1,15 & 559,8 & 497,9 & 550 \\
\hline 3 & 3 & 97 & 601 & 533 & 624 & 530 & 572 & 47,85 & 0,89 & 1,09 & 1,15 & 626,9 & 516,9 & 572 \\
\hline 3 & 5 & 95 & 603 & 612 & 579 & 583 & 594 & 15,93 & 0,98 & 1,13 & 1,15 & 612,5 & 575,9 & 594 \\
\hline 3 & 7 & 93 & 688 & 693 & 646 & 676 & 676 & 20,86 & 1,41 & 0,81 & 1,15 & 699,7 & 651,7 & 693 \\
\hline 3 & 10 & 90 & 746 & 695 & 754 & 665 & 715 & 42,37 & 1,18 & 0,93 & 1,15 & 763,7 & 666,3 & 754 \\
\hline 7 & 0 & 100 & 544 & 615 & 554 & 561 & 568 & 31,55 & 0,23 & 1,46 & 1,15 & 604,8 & 532,2 & 561 \\
\hline 7 & 3 & 97 & 518 & 644 & 585 & 542 & 572 & 55,47 & 0,98 & 1,30 & 1,15 & 636,0 & 508,4 & 585 \\
\hline 7 & 5 & 95 & 613 & 606 & 606 & 602 & 607 & 4,32 & 0,98 & 1,40 & 1,15 & 611,5 & 601,6 & 606 \\
\hline 7 & 7 & 93 & 738 & 715 & 712 & 710 & 719 & 13,07 & 0,65 & 1,48 & 1,15 & 733,9 & 703,8 & 715 \\
\hline 7 & 10 & 90 & 850 & 854 & 846 & 822 & 843 & 14,38 & 1,47 & 0,74 & 1,15 & 859,5 & 826,4 & 854 \\
\hline 28 & 0 & 100 & 530 & 580 & 668 & 550 & 582 & 60,83 & 0,85 & 1,41 & 1,15 & 652,1 & 512,2 & 580 \\
\hline 28 & 3 & 97 & 686 & 790 & 623 & 691 & 698 & 68,96 & 1,08 & 1,34 & 1,15 & 776,8 & 618,2 & 691 \\
\hline 28 & 5 & 95 & 810 & 772 & 799 & 795 & 794 & 15,92 & 1,38 & 0,99 & 1,15 & 812,5 & 775,9 & 810 \\
\hline 28 & 7 & 93 & 899 & 858 & 851 & 856 & 866 & 21,92 & 0,66 & 1,49 & 1,15 & 891,2 & 840,8 & 858 \\
\hline 28 & 10 & 90 & 1026 & 1022 & 1013 & 1017 & 1020 & 5,736 & 1,14 & 1,16 & 1,15 & 1026,3 & 1013,1 & 1022 \\
\hline
\end{tabular}

Tabela E2 - Identificação dos outliers do ensaio de resistência à compressão simples após imersão prévia em água (kPa)

\begin{tabular}{|c|c|c|c|c|c|c|c|c|c|c|c|c|c|c|}
\hline \multirow{2}{*}{$\begin{array}{c}\text { cura } \\
\text { (dias) } \\
\end{array}$} & \multirow{2}{*}{$\begin{array}{l}\text { cal } \\
(\%) \\
\end{array}$} & \multirow{2}{*}{$\begin{array}{c}\text { resíduo } \\
(\%)\end{array}$} & \multicolumn{4}{|c|}{ corpo de prova } & \multirow{2}{*}{$\begin{array}{l}\text { média } \\
(\mathrm{KPa})\end{array}$} & \multirow{2}{*}{$\begin{array}{l}\text { desvio } \\
\text { padrão }\end{array}$} & \multirow{2}{*}{$\begin{array}{c}\text { G } \\
\text { Maior } \\
\end{array}$} & \multirow{2}{*}{$\begin{array}{c}\text { G } \\
\text { Menor }\end{array}$} & \multirow{2}{*}{$\begin{array}{c}\text { Gcrítico } \\
95 \%\end{array}$} & \multirow{2}{*}{$\begin{array}{r}Y \\
\text { máx } \\
\end{array}$} & \multirow{2}{*}{$\begin{array}{c}\text { Y } \\
\text { Mín } \\
\end{array}$} & \multirow{2}{*}{$\begin{array}{c}\text { Média } \\
\text { adotada }\end{array}$} \\
\hline & & & 1 & 2 & 3 & 4 & & & & & & & & \\
\hline 0 & 0 & 100 & nd & nd & nd & nd & nd & nd & nd & nd & 1,15 & nd & nd & nd \\
\hline 0 & 3 & 97 & nd & nd & nd & nd & nd & nd & nd & nd & 1,15 & nd & nd & nd \\
\hline 0 & 5 & 95 & nd & nd & nd & nd & nd & nd & nd & nd & 1,15 & nd & nd & nd \\
\hline 0 & 7 & 93 & nd & nd & nd & nd & nd & nd & nd & nd & 1,15 & nd & nd & nd \\
\hline 0 & 10 & 90 & nd & nd & nd & nd & nd & nd & nd & nd & 1,15 & nd & nd & nd \\
\hline 3 & 0 & 100 & nd & nd & nd & nd & nd & nd & nd & nd & 1,15 & nd & nd & nd \\
\hline 3 & 3 & 97 & 301,62 & 342,3 & 349 & 302,6 & 323,87 & 25,29 & 0,880 & 0,995 & 1,15 & 352,95 & 294,78 & 324 \\
\hline 3 & 5 & 95 & 337,76 & 322,7 & 353,1 & 383,96 & 349,38 & 26,18 & 1,019 & 1,321 & 1,15 & 379,48 & 319,28 & 353 \\
\hline 3 & 7 & 93 & 553,5 & 513,3 & 423,2 & 411,7 & 475,41 & 69,08 & 0,922 & 1,130 & 1,15 & 554,86 & 395,96 & 475 \\
\hline 3 & 10 & 90 & 575,47 & 414,9 & 614,40 & 419,5 & 506,07 & 103,86 & 0,877 & 1,043 & 1,15 & 625,50 & 386,63 & 506 \\
\hline 7 & 0 & 100 & nd & nd & nd & nd & nd & nd & nd & nd & 1,15 & nd & nd & nd \\
\hline 7 & 3 & 97 & 375,63 & 358,9 & 357,6 & 363,10 & 363,81 & 8,22 & 0,751 & 1,438 & 1,15 & 373,26 & 354,36 & 363 \\
\hline 7 & 5 & 95 & 357,48 & 395 & 504 & 350,4 & 401,71 & 70,96 & 0,723 & 1,442 & 1,15 & 483,31 & 320,11 & 395 \\
\hline 7 & 7 & 93 & 450,34 & 565,1 & 618,9 & 497,3 & 532,93 & 74,21 & 1,113 & 1,159 & 1,15 & 618,27 & 447,59 & 565 \\
\hline 7 & 10 & 90 & 626,54 & 615,6 & 630,5 & 653 & 631,42 & 15,70 & 1,005 & 1,375 & 1,15 & 649,47 & 613,36 & 630 \\
\hline 28 & 0 & 100 & nd & nd & nd & nd & nd & nd & nd & nd & 1,15 & nd & nd & nd \\
\hline 28 & 3 & 97 & 558,56 & 556,8 & 536,6 & 530,8 & 545,68 & 14,08 & 1,058 & 0,915 & 1,15 & 561,87 & 529,49 & 546 \\
\hline 28 & 5 & 95 & 596,70 & 617,8 & 574,2 & 621,8 & 602,62 & 21,92 & 1,297 & 0,873 & 1,15 & 627,82 & 577,42 & 622 \\
\hline 28 & 7 & 93 & 778,46 & 712,1 & 682,44 & 697,6 & 717,65 & 42,31 & 0,832 & 1,437 & 1,15 & 766,30 & 669,00 & 712 \\
\hline 28 & 10 & 90 & 833,13 & 836,40 & 855 & 853,1 & 844,41 & 11,24 & 1,003 & 0,941 & 1,15 & 857,34 & 831,48 & 844 \\
\hline
\end{tabular}


Tabela E3 - Identificação dos outliers dos valores do módulo tangente inicial $\left(E_{0}\right)$ para os corpos de prova ensaiados sem imersão prévia em água (KPa)

\begin{tabular}{|c|c|c|c|c|c|c|c|c|c|c|c|c|c|c|}
\hline cura & cal & esíduo & & corpo & le prove & & média & desvio & G & G & Gcrítico & $\mathbf{Y}$ & $\mathbf{Y}$ & Média \\
\hline (dias) & $(\%)$ & $(\%)$ & 1 & 2 & 3 & 4 & (KPa) & padrão & Maior & Menor & 0,95 & máx & Mín & adotada \\
\hline 0 & 0 & 100 & 16916 & 25644 & 16789 & 15179 & 18632 & 4741 & 0,728 & 1,479 & 1,15 & 24084 & 13180 & 16916 \\
\hline 0 & 3 & 97 & 18900 & 19785 & 17845 & 18986 & 18879 & 796,2 & 1,299 & 1,138 & 1,15 & 19795 & 17963 & 19785 \\
\hline 0 & 5 & 95 & 20402 & 18469 & 19777 & 20497 & 19786 & 934,4 & 1,41 & 0,659 & 1,15 & 20861 & 18712 & 20497 \\
\hline 0 & 7 & 93 & 22954 & 22900 & 22000 & 18234 & 21522 & 2235 & 1,471 & 0,641 & 1,15 & 24093 & 18951 & 22954 \\
\hline 0 & 10 & 90 & 25757 & 16460 & 22000 & 27881 & 23025 & 5006 & 1,311 & 0,97 & 1,15 & 28782 & 17267 & 27881 \\
\hline 3 & 0 & 100 & 37347 & 38000 & 43629 & 38000 & 39244 & 2939 & 0,645 & 1,492 & 1,15 & 42624 & 35864 & 38000 \\
\hline 3 & 3 & 97 & 21913 & 51942 & 53000 & 24897 & 37938 & 16831 & 0,952 & 0,895 & 1,15 & 57294 & 18582 & 38000 \\
\hline 3 & 5 & 95 & 58305 & 62757 & 48057 & 49000 & 54530 & 7174 & 0,902 & 1,147 & 1,15 & 62780 & 46279 & 54540 \\
\hline 3 & 7 & 93 & 58635 & 58000 & 50552 & 53023 & 55053 & 3911 & 1,151 & 0,916 & 1,15 & 59551 & 50554 & 58635 \\
\hline 3 & 10 & 90 & 55000 & 62670 & 60811 & 51376 & 57464 & 5210 & 1,169 & 1,00 & 1,15 & 63456 & 51472 & 60811 \\
\hline 7 & 0 & 100 & 58311 & 64667 & 65754 & 63200 & 62983 & 3286 & 1,422 & 0,843 & 1,15 & 66762 & 59204 & 65754 \\
\hline 7 & 3 & 97 & 83303 & 81000 & 38327 & 64084 & 66679 & 20753 & 1,366 & 0,801 & 1,15 & 90544 & 42813 & 83303 \\
\hline 7 & 5 & 95 & 71000 & 83000 & 65245 & 43482 & 65682 & 16545 & 1,342 & 1,047 & 1,15 & 84709 & 46655 & 83000 \\
\hline 7 & 7 & 93 & 80000 & 70275 & 84000 & 65000 & 74819 & 8722 & 1,126 & 1,053 & 1,15 & 84848 & 64789 & 84000 \\
\hline 7 & 10 & 90 & 81000 & $1 \mathrm{E}+05$ & 81000 & 85522 & 86964 & 9164 & 0,651 & 1,459 & 1,15 & 97503 & 76425 & 85522 \\
\hline 28 & 0 & 100 & 20910 & 37744 & 35902 & 49000 & 35889 & 11543 & 1,298 & 1,136 & 1,15 & 49163 & 22615 & 49000 \\
\hline 28 & 3 & 97 & 76279 & 85000 & 55882 & 89096 & 76564 & 14788 & 1,399 & 0,847 & 1,15 & 93570 & 59558 & 89096 \\
\hline 28 & 5 & 95 & 88000 & 86917 & 90228 & 64677 & 82456 & 11932 & 1,49 & 0,651 & 1,15 & 96178 & 68733 & 90228 \\
\hline 28 & 7 & 93 & $1 \mathrm{E}+05$ & $1 \mathrm{E}+05$ & 88000 & 100000 & 99749 & 9162 & 1,282 & 1,16 & 1,15 & 110285 & 89212 & 100616 \\
\hline 28 & 10 & 90 & 59000 & $1 \mathrm{E}+05$ & $1 E+05$ & 115000 & 96000 & 25232 & 1,466 & 0,753 & 1,15 & 125017 & 66983 & 115000 \\
\hline
\end{tabular}

\begin{tabular}{|c|c|c|c|c|c|c|c|c|c|c|c|c|c|c|}
\hline \multirow{2}{*}{$\begin{array}{c}\text { cura } \\
\text { (dias) }\end{array}$} & \multirow{2}{*}{$\begin{array}{l}\text { cal } \\
(\%)\end{array}$} & \multirow{2}{*}{$\begin{array}{c}\text { resíduo } \\
(\%)\end{array}$} & \multicolumn{4}{|c|}{ corpo de prova } & \multirow{2}{*}{$\begin{array}{l}\text { média } \\
(\mathrm{KPa}))\end{array}$} & \multirow{2}{*}{$\begin{array}{l}\text { desvio } \\
\text { padrão }\end{array}$} & \multirow{2}{*}{$\begin{array}{c}\text { G } \\
\text { Maior }\end{array}$} & \multirow{2}{*}{$\begin{array}{c}\mathbf{G} \\
\text { Menor }\end{array}$} & \multirow{2}{*}{$\begin{array}{c}\text { Gcrítico } \\
0,95\end{array}$} & \multirow{2}{*}{$\begin{array}{c}\text { Y } \\
\text { máx }\end{array}$} & \multirow{2}{*}{$\begin{array}{c}\text { Y } \\
\text { Mín }\end{array}$} & \multirow{2}{*}{$\begin{array}{c}\text { Média } \\
\text { adotada }\end{array}$} \\
\hline & & & 1 & 2 & 3 & 4 & & & & & & & & \\
\hline 0 & 0 & 100 & nd & nd & $\overline{n d}$ & nd & nd & nd & nd & nd & 1,15 & nd & nd & nd \\
\hline 0 & 3 & 97 & nd & nd & nd & nd & nd & nd & nd & nd & 1,15 & nd & nd & nd \\
\hline 0 & 5 & 95 & nd & nd & nd & nd & nd & nd & nd & nd & 1,15 & nd & nd & nd \\
\hline 0 & 7 & 93 & nd & nd & nd & nd & nd & nd & nd & nd & 1, & nd & nd & d \\
\hline 0 & 10 & 90 & nd & nd & nd & nd & nd & nd & nd & nd & 1,15 & nd & nd & nd \\
\hline 3 & 0 & 100 & nd & nd & nd & nd & nd & nd & nd & nd & 1,15 & nd & nd & nd \\
\hline 3 & 3 & 97 & 34819 & 18006 & 12000 & 7299 & 18031 & 12019 & 0,89 & 1,40 & 1,15 & 31853 & 4209 & 18006 \\
\hline 3 & 5 & 95 & 35000 & 22233 & 25503 & 27403 & 27535 & 5416 & 0,98 & 1,38 & 1,15 & 33763 & 21307 & 27403 \\
\hline 3 & 7 & 93 & 41180 & 30743 & 55000 & 31000 & 39481 & 11431 & 0,76 & 1,36 & 1,15 & 52626 & 26335 & 41180 \\
\hline 3 & 10 & 90 & 55087 & 45000 & 38888 & 14249 & 38306 & 17373 & 1,38 & 0,97 & 1,15 & 58285 & 18327 & 55087 \\
\hline 7 & 0 & 100 & nd & nd & nd & nd & nd & nd & nd & nd & 1,15 & nd & nd & nd \\
\hline 7 & 3 & 97 & 37130 & 40000 & 33348 & 29000 & 34870 & 4768 & 1,23 & 1,08 & 1,15 & 40353 & 29386 & 40000 \\
\hline 7 & 5 & 95 & 49777 & 51000 & 55237 & 43482 & 49874 & 4861 & 1,31 & 1,10 & 1,15 & 55464 & 44284 & 55237 \\
\hline 7 & 7 & 93 & 47000 & 17973 & 54173 & $1 \mathrm{E}+05$ & 55822 & 35814 & 1,06 & 1,35 & 1,15 & 97009 & 14636 & 54173 \\
\hline 7 & 10 & 90 & 75433 & 74358 & 79953 & 75000 & 76186 & 2550 & 0,72 & 1,48 & 1,15 & 79118 & 73254 & 75433 \\
\hline 28 & 0 & 100 & nd & nd & nd & nd & nd & nd & nd & nd & 1,15 & nd & nd & nd \\
\hline 28 & 3 & 97 & 71000 & 72749 & 86147 & 77842 & 76935 & 6793 & 0,87 & 1,36 & 1,15 & 84746 & 69123 & 78000 \\
\hline 28 & 5 & 95 & $2 E+05$ & 82402 & 82000 & $1 \mathrm{E}+05$ & $1 E+05$ & 72974 & 0,75 & 0,14 & 1,15 & 220831 & 52991 & 146884 \\
\hline 28 & 7 & 93 & $1 \mathrm{E}+05$ & 62095 & 92064 & 98000 & 88730 & 18287 & 1,46 & 0,77 & 1,15 & 109760 & 67699 & 102.759 \\
\hline 28 & 10 & 90 & $1 E+05$ & 113000 & 59918 & $1 \mathrm{E}+05$ & 97292 & 25689 & 1,45 & 0,70 & 1,15 & 126833 & 67750 & 108000 \\
\hline
\end{tabular}




\begin{tabular}{|c|c|c|c|c|c|c|c|c|c|c|c|c|c|c|}
\hline \multirow{2}{*}{$\begin{array}{r}\text { cura } \\
\text { (dias) } \\
\end{array}$} & \multirow{2}{*}{$\begin{array}{l}\mathrm{cal} \\
(\%) \\
\end{array}$} & \multirow{2}{*}{$\begin{array}{c}\text { resíduo } \\
(\%) \\
\end{array}$} & \multicolumn{4}{|c|}{ corpo-de-prova } & \multirow[t]{2}{*}{ média } & \multirow{2}{*}{$\begin{array}{l}\text { desvio } \\
\text { padrão }\end{array}$} & \multirow{2}{*}{$\begin{array}{c}G \\
\text { Maior } \\
\end{array}$} & \multirow{2}{*}{$\begin{array}{c}\text { G } \\
\text { Menor }\end{array}$} & \multirow{2}{*}{$\begin{array}{c}\text { Gcrítico } \\
0,95 \\
\end{array}$} & \multirow{2}{*}{$\begin{array}{c}\mathrm{Y} \\
\text { máx }\end{array}$} & \multirow{2}{*}{$\begin{array}{c}\text { Y } \\
\text { Mín } \\
\end{array}$} & \multirow{2}{*}{$\begin{array}{c}\text { Média } \\
\text { adotada }\end{array}$} \\
\hline & & & 1 & 2 & 3 & 4 & & & & & & & & \\
\hline 0 & 0 & 100 & 28,77 & 29,00 & 29,00 & 29,00 & 28,943 & 0,115 & 1,50 & 0,50 & 1,15 & 29,07 & 28,81 & 29,06 \\
\hline 0 & 3 & 97 & 30 & 29 & 24 & 36 & 30 & 4,795 & 1,16 & 1,28 & 1,15 & 35 & 24 & 30 \\
\hline 0 & 5 & 95 & 34 & 29 & 32 & 34 & 32 & 2,543 & 1,39 & 0,74 & 1,15 & 35 & 29 & 34 \\
\hline 0 & 7 & 93 & 35 & 37 & 40 & 40 & 38 & 2,568 & 1,30 & 0,82 & 1,15 & 41 & 35 & 40 \\
\hline 0 & 10 & 90 & 40 & 45 & 46 & 43 & 44 & 2,667 & 1,33 & 0,85 & 1,15 & 47 & 41 & 46 \\
\hline 3 & 0 & 100 & 38 & 35 & 40 & 40 & 38 & 2,578 & 1,37 & 0,79 & 1,15 & 41 & 35 & 40 \\
\hline 3 & 3 & 97 & 41 & 41 & 40 & 42 & 41 & 0,914 & 0,99 & 1,33 & 1,15 & 42 & 40 & 41 \\
\hline 3 & 5 & 95 & 46 & 40 & 40 & 43 & 42 & 2,741 & 0,79 & 1, & 1,15 & 45 & 39 & 43 \\
\hline 3 & 7 & 93 & 47 & 46 & 46 & 46 & 46 & 0,415 & 0,50 & 1,50 & 1,15 & 46 & 45 & 46 \\
\hline 3 & 10 & 90 & 55 & 57 & 51 & 57 & 55 & 2,674 & 1,39 & 0,75 & 1,15 & 58 & 52 & 57 \\
\hline 7 & 0 & 100 & 46 & 41 & 39 & 40 & 41 & 3,461 & 0,83 & $\overline{1,4}$ & 1,15 & 45 & 37 & 41 \\
\hline 7 & 3 & 97 & 46 & 52 & 52 & 40 & 47 & 5,781 & 1,29 & 0,8 & 1,15 & 54 & 41 & 52 \\
\hline 7 & 5 & 95 & 49 & 57 & 57 & 49 & 53 & 4,747 & 0,87 & 0,91 & 1,15 & 58 & 47 & 53 \\
\hline 7 & 7 & 93 & 66 & 58 & 54 & 57 & 59 & 4,974 & 0,89 & 1,43 & 1,15 & 64 & 53 & 58 \\
\hline 7 & 10 & 90 & 69 & 63 & 63 & 57 & 63 & 4,716 & 1,22 & 1,23 & 1,15 & 68 & 57 & 63 \\
\hline 28 & $\overline{0}$ & 100 & 58 & 52 & 46 & 49 & 52 & 5,157 & 1,01 & 1,33 & 1,15 & 57 & 46 & 52 \\
\hline 28 & 3 & 97 & 77 & 74 & 71 & 65 & 72 & 4,984 & 1,31 & 1,05 & 1,15 & 77 & 66 & 77 \\
\hline 28 & 5 & 95 & 83 & 82 & 82 & 82 & 82 & 0,329 & 1,33 & 1,10 & 1,15 & 83 & 82 & 83 \\
\hline 28 & 7 & 93 & 94 & 85 & 97 & 94 & 92 & 5,130 & 1,44 & 0,87 & 1,15 & 98 & 86 & 97 \\
\hline 28 & 10 & 90 & 108 & 113 & 112 & 114 & 112 & 2,807 & 1,38 & 0,88 & 1,15 & 115 & 108 & 114 \\
\hline
\end{tabular}

Tabela E6 - Identificação dos outliers do ensaio de resistência à tração por compressão diametral após imersão prévia em água

\begin{tabular}{|c|c|c|c|c|c|c|c|c|c|c|c|c|c|c|}
\hline $\begin{array}{c}\text { cura } \\
\text { (dias) } \\
\end{array}$ & $\begin{array}{l}\text { cal } \\
(\%)\end{array}$ & $\begin{array}{c}\text { resíduo } \\
(\%)\end{array}$ & $\begin{array}{c}\text { corp } \\
1 \\
\end{array}$ & $\begin{array}{c}\text { o-d } \\
2 \\
\end{array}$ & $\begin{array}{c}\text { e-pr } \\
3 \\
\end{array}$ & $\begin{array}{c}\text { ova } \\
4 \\
\end{array}$ & média & $\begin{array}{l}\text { desvio } \\
\text { padrão }\end{array}$ & $\begin{array}{c}\mathbf{G} \\
\text { Maior } \\
\end{array}$ & $\begin{array}{c}\text { G } \\
\text { Menor }\end{array}$ & $\begin{array}{c}\text { Gcrítico } \\
95 \% \\
\end{array}$ & $\begin{array}{c}\text { Y } \\
\text { máx } \\
\end{array}$ & $\begin{array}{r}\text { Y } \\
\text { Mín } \\
\end{array}$ & $\begin{array}{c}\text { Média } \\
\text { adotada }\end{array}$ \\
\hline 0 & 0 & 100 & 0 & 0 & 0 & 0 & 0,00 & 0,00 & 0,000 & 0,000 & 1,15 & 0,00 & 0,00 & 0 \\
\hline 0 & 3 & 97 & 0 & 0 & 0 & 0 & 0,00 & 0,00 & 0,000 & 0,000 & 1,15 & 0,00 & 0,00 & 0 \\
\hline 0 & 5 & 95 & 0 & 0 & 0 & 0 & 0,00 & 0,00 & 0,000 & 0,000 & 1,15 & 0,00 & 0,00 & 0 \\
\hline 0 & 7 & 93 & 0 & 0 & 0 & 0 & 0,00 & 0,00 & 0,000 & 0,000 & 1,15 & 0,00 & 0,00 & 0 \\
\hline 0 & 10 & 90 & 0 & 0 & 0 & 0 & 0,00 & 0,00 & 0,000 & 0,000 & 1,15 & 0,00 & 0,00 & 0 \\
\hline 3 & 0 & 100 & 0 & 0 & 0 & 0 & 0 & 0,00 & 0,000 & 0,000 & 1,15 & 0,00 & 0,00 & 0 \\
\hline 3 & 3 & 97 & 28 & 28 & 29 & 17 & 26 & 5,73 & 1,499 & 0,546 & 1,15 & 32,29 & 19,12 & 29 \\
\hline 3 & 5 & 95 & 29 & 24 & 29 & 29 & 28 & 2,62 & 1,494 & 0,571 & 1,15 & 30,64 & 24,61 & 29 \\
\hline 3 & 7 & 93 & 34 & 35 & 34 & 34 & 34 & 0,21 & 0,872 & 1,374 & 1,15 & 34,54 & 34,06 & 34 \\
\hline 3 & 10 & 90 & 46 & 46 & 45 & 45 & 46 & 0,24 & 1,158 & 1,158 & 1,15 & 45,86 & 45,31 & 46 \\
\hline 7 & 0 & 100 & 0 & 0 & 0 & 0 & 0,00 & 0,00 & 0,000 & 0,000 & 1,15 & 0,00 & 0,00 & 0 \\
\hline 7 & 3 & 97 & 35 & 29 & 29 & 32 & 31 & 2,99 & 0,805 & 1,282 & 1,15 & 34,49 & 27,62 & 32 \\
\hline 7 & 5 & 95 & 31 & 29 & 32 & 33 & 32 & 1,86 & 1,350 & 0,972 & 1,15 & 33,72 & 29,43 & 33 \\
\hline 7 & 7 & 93 & 35 & 35 & 29 & 40 & 34 & 4,61 & 1,261 & 1,186 & 1,15 & 39,72 & 29,11 & 35 \\
\hline 7 & 10 & 90 & 51 & 51 & 51 & 51 & 51 & 0,10 & 1,306 & 0,783 & 1,15 & 51,32 & 51,09 & 51 \\
\hline 28 & 0 & 100 & 0 & 0 & 0 & 0 & 0,00 & 0,00 & 0,000 & 0,000 & 1,15 & 0,00 & 0,00 & 0 \\
\hline 28 & 3 & 97 & 57 & 56 & 62 & 59 & 59 & 2,64 & 0,819 & 1,313 & 1,15 & 61,63 & 55,55 & 59 \\
\hline 28 & 5 & 95 & 65 & 71 & 66 & 69 & 68 & 2,71 & 0,898 & 1,303 & 1,15 & 70,93 & 64,70 & 69 \\
\hline 28 & 7 & 93 & 69 & 74 & 80 & 71 & 73 & 4,79 & 1,042 & 1,311 & 1,15 & 78,99 & 67,98 & 74 \\
\hline 28 & 10 & 90 & 83 & 82 & 85 & 94 & 86 & 5,44 & 0,738 & 1,448 & 1,15 & 92,37 & 79,87 & 85 \\
\hline
\end{tabular}


- ANEXO F -

ANÁLISE DE VARIÂNCIA 
Experimento fatorial para o ensaio de resistência à compressão simples

Fatores

\begin{tabular}{|c|c|c|c|c|c|}
\hline & & Níveis & & rição & Repetições $r=\mathbf{4}$ \\
\hline \multirow[t]{2}{*}{$A$} & Condição de ensaio & 2 & 0 & Sem imersão & \\
\hline & & & 1 & Com imersão & \\
\hline \multirow[t]{4}{*}{ B } & Tempo de cura & 4 & 0 & Imediato (0) & \\
\hline & & & 1 & 3 dias & \\
\hline & & & 2 & 7 dias & \\
\hline & & & 3 & 28 dias & \\
\hline \multirow[t]{6}{*}{ C } & Teor de cal & 5 & 0 & $0 \%$ & \\
\hline & & & 1 & $3 \%$ & \\
\hline & & & 2 & $5 \%$ & \\
\hline & & & 3 & $7 \%$ & \\
\hline & & & 4 & $10 \%$ & \\
\hline & & 40 & & & \\
\hline
\end{tabular}


Tabela F.1 - Análise experimental para o ensaio de resistência à compressão simples

\begin{tabular}{|c|c|c|c|c|c|c|c|c|c|c|}
\hline \multirow[b]{3}{*}{$\begin{array}{l}\text { Cond. } \\
\text { Exp. }\end{array}$} & \multirow{3}{*}{$\begin{array}{l}\text { (A) } \\
\text { Cond. } \\
\text { ensaio }\end{array}$} & \multirow[b]{3}{*}{ (B) tc } & \multirow[b]{3}{*}{$\begin{array}{c}\text { (C) \% } \\
\text { cal }\end{array}$} & \multicolumn{4}{|c|}{ RCS } & \multirow{3}{*}{$\begin{array}{c}\text { Total } \\
\text { parcial. } \\
\mathbf{T}_{(\mathrm{c})}\end{array}$} & \multirow{3}{*}{$\mathrm{Tc} / \mathrm{r}$} & \multirow{3}{*}{$\sum_{k=1}^{r} y_{k}^{2}$} \\
\hline & & & & \multicolumn{4}{|c|}{ Repetições } & & & \\
\hline & & & & y1 & y2 & y3 & y4 & & & \\
\hline 1 & 0 & 0 & 0 & 395 & 530 & 487 & 523 & 1935,59 & 483,8975 & 948217 \\
\hline 2 & 1 & 0 & 0 & 473 & 479 & 471 & 470 & 1892,82 & 473,205 & 895736 \\
\hline 3 & 0 & 1 & 0 & 529 & 495 & 522 & 493 & 2039,96 & 509,99 & 1041356 \\
\hline 4 & 1 & 1 & 0 & 585 & 659 & 538 & 624 & 2405,79 & 601,4475 & 1455107 \\
\hline 5 & 0 & 2 & 0 & 684 & 695 & 627 & 715 & 2720,88 & 680,22 & 1855071 \\
\hline 6 & 1 & 2 & 0 & 490 & 542 & 534 & 550 & 2115,34 & 528,835 & 1120841 \\
\hline 7 & 0 & 3 & 0 & 601 & 533 & 624 & 530 & 2287,57 & 571,8925 & 1315113 \\
\hline 8 & 1 & 3 & 0 & 603 & 612 & 579 & 583 & 2376,83 & 594,2075 & 1413092 \\
\hline 9 & 0 & 0 & 1 & 688 & 693 & 646 & 676 & 2702,82 & 675,705 & 1827615 \\
\hline 10 & 1 & 0 & 1 & 746 & 695 & 754 & 665 & 2860,01 & 715,0025 & 2050300 \\
\hline 11 & 0 & 1 & 1 & 544 & 615 & 554 & 561 & 2273,89 & 568,4725 & 1295631 \\
\hline 12 & 1 & 1 & 1 & 518 & 644 & 585 & 542 & 2288,87 & 572,2175 & 1318963 \\
\hline 13 & 0 & 2 & 1 & 613 & 606 & 606 & 602 & 2426,23 & 606,5575 & 1471704 \\
\hline 14 & 1 & 2 & 1 & 738 & 715 & 712 & 710 & 2875,46 & 718,865 & 2067580 \\
\hline 15 & 0 & 3 & 1 & 850 & 854 & 846 & 822 & 3371,88 & 842,97 & 2843014 \\
\hline 16 & 1 & 3 & 1 & 530 & 580 & 668 & 550 & 2328,62 & 582,155 & 1366717 \\
\hline 17 & 0 & 0 & 2 & 686 & 790 & 623 & 691 & 2790,19 & 697,5475 & 1960555 \\
\hline 18 & 1 & 0 & 2 & 810 & 772 & 799 & 795 & 3176,8 & 794,2 & 2523775 \\
\hline 19 & 0 & 1 & 2 & 899 & 858 & 851 & 856 & 3463,93 & 865,9825 & 3001144 \\
\hline 20 & 1 & 1 & 2 & 1026 & 1022 & 1013 & 1017 & 4078,93 & 1019,733 & 4159516 \\
\hline 21 & 0 & 2 & 2 & 0 & 0 & 0 & 0 & 0 & 0 & 0 \\
\hline 22 & 1 & 2 & 2 & 0 & 0 & 0 & 0 & 0 & 0 & 0 \\
\hline 23 & 0 & 3 & 2 & 0 & 0 & 0 & 0 & 0 & 0 & 0 \\
\hline 24 & 1 & 3 & 2 & 0 & 0 & 0 & 0 & 0 & 0 & 0 \\
\hline 25 & 0 & 0 & 3 & 0 & 0 & 0 & 0 & 0 & 0 & 0 \\
\hline 26 & 1 & 0 & 3 & 0 & 0 & 0 & 0 & 0 & 0 & 0 \\
\hline 27 & 0 & 1 & 3 & 302 & 342 & 349 & 303 & 1295,47 & 323,8675 & 421479 \\
\hline 28 & 1 & 1 & 3 & 338 & 323 & 353 & 384 & 1397,52 & 349,38 & 490321 \\
\hline 29 & 0 & 2 & 3 & 554 & 513 & 423 & 412 & 1901,63 & 475,4075 & 918367 \\
\hline 30 & 1 & 2 & 3 & 575 & 415 & 614 & 419 & 2024,27 & 506,0675 & 1056775 \\
\hline 31 & 0 & 3 & 3 & 0 & 0 & 0 & 0 & 0 & 0 & 0 \\
\hline 32 & 1 & 3 & 3 & 376 & 359 & 358 & 363 & 1455,24 & 363,81 & 529634 \\
\hline 33 & 0 & 0 & 4 & 357 & 395 & 504 & 350 & 1606,84 & 401,71 & 660588 \\
\hline 34 & 1 & 0 & 4 & 450 & 565 & 619 & 497 & 2131,71 & 532,9275 & 1152567 \\
\hline 35 & 0 & 1 & 4 & 627 & 616 & 630 & 653 & 2525,66 & 631,415 & 1595479 \\
\hline 36 & 1 & 1 & 4 & 0 & 0 & 0 & 0 & 0 & 0 & 0 \\
\hline 37 & 0 & 2 & 4 & 559 & 557 & 537 & 531 & 2182,72 & 545,68 & 1191661 \\
\hline 38 & 1 & 2 & 4 & 597 & 618 & 574 & 622 & 2410,48 & 602,62 & 1454044 \\
\hline 39 & 0 & 3 & 4 & 778 & 712 & 682 & 698 & 2870,6 & 717,65 & 2065456 \\
\hline 40 & 1 & 3 & 4 & 833 & 836 & 855 & 853 & 3377,64 & 844,41 & 2852492 \\
\hline & & & & & & & Total & 77592,19 & 19398,05 & $5 \mathrm{E}+07$ \\
\hline
\end{tabular}




$$
C=\frac{T^{2}}{N}=37628424,6812 \quad S Q_{\text {total }}=\sum_{c=1}^{m} \sum_{k=1}^{r} y_{c k}^{2}-\frac{T^{2}}{N}=12691485,6488
$$
A
média Desvio padrão

0

$655,14 \quad 4,253$

1

$314,75 \quad 4,253$

B

0

$274,85 \quad 6,015$

1

$474,07 \quad 6,015$

2

$523,90 \quad 6,015$

3

$666,95 \quad 6,015$

C

0

$270,41 \quad 6,725$

1

$443,62 \quad 6,725$

2

$482,31 \quad 6,725$

3

$573,47 \quad 6,725$

4

$654,91 \quad 6,725$

A B

$0 \quad 0$

$549,70 \quad 8,506$

$0 \quad 1$

$617,20 \quad 8,506$

02

$661,85 \quad 8,506$

03

$791,80 \quad 8,506$

10

$-0,00 \quad 8,506$

11

$330,95 \quad 8,506$

12

$385,95 \quad 8,506$

13

$542,10 \quad 8,506$ 


\begin{tabular}{|c|c|c|c|}
\hline $\mathbf{A}$ & C & & \\
\hline 0 & 0 & 540,81 & 9,510 \\
\hline 0 & 1 & 578,75 & 9,510 \\
\hline 0 & 2 & 626,19 & 9,510 \\
\hline 0 & 3 & 715,50 & 9,510 \\
\hline 0 & 4 & 814,44 & 9,510 \\
\hline 1 & 0 & 0,00 & 9,510 \\
\hline 1 & 1 & 308,50 & 9,510 \\
\hline 1 & 2 & 338,44 & 9,510 \\
\hline 1 & 3 & 431,44 & 9,510 \\
\hline 1 & 4 & 495,37 & 9,510 \\
\hline B & C & & \\
\hline 0 & 0 & 241,88 & 13,449 \\
\hline 0 & 1 & 236,62 & 13,449 \\
\hline 0 & 2 & 254,87 & 13,449 \\
\hline 0 & 3 & 300,75 & 13,449 \\
\hline 0 & 4 & 340,13 & 13,449 \\
\hline 1 & 0 & 264,50 & 13,449 \\
\hline 1 & 1 & 448,00 & 13,449 \\
\hline 1 & 2 & 471,87 & 13,449 \\
\hline 1 & 3 & 575,62 & 13,449 \\
\hline B & C & Média & Desvio padrão \\
\hline 1 & 4 & 610,37 & 13,449 \\
\hline 2 & 0 & 284,25 & 13,449 \\
\hline
\end{tabular}


21

22

23

24

30

31

32

33

34

A B C

$\begin{array}{lll}0 & 0 & 0\end{array}$

$\begin{array}{lll}0 & 0 & 1\end{array}$

$\begin{array}{lll}0 & 0 & 2\end{array}$

$\begin{array}{lll}0 & 0 & 3\end{array}$

$\begin{array}{lll}0 & 0 & 4\end{array}$

$\begin{array}{lll}0 & 1 & 0\end{array}$

$\begin{array}{lll}0 & 1 & 1\end{array}$

$\begin{array}{lll}0 & 1 & 2\end{array}$

$\begin{array}{lll}0 & 1 & 3\end{array}$

$\begin{array}{lll}0 & 1 & 4\end{array}$

$\begin{array}{lll}0 & 2 & 0\end{array}$

$\begin{array}{lll}0 & 2 & 1\end{array}$

$\begin{array}{lll}0 & 2 & 2\end{array}$

$\begin{array}{lll}0 & 2 & 3\end{array}$
$468,12 \quad 13,449$

$504,13 \quad 13,449$

$625,75 \quad 13,449$

$737,25 \quad 13,449$

$291,00 \quad 13,449$

$621,75 \quad 13,449$

$698,38 \quad 13,449$

$791,75 \quad 13,449$

$931,87 \quad 13,449$

$483,75 \quad 19,020$

$473,25 \quad 19,020$

$509,75 \quad 19,020$

$601,50 \quad 19,020$

$680,25 \quad 19,020$

$529,00 \quad 19,020$

$572,00 \quad 19,020$

$594,25 \quad 19,020$

$675,75 \quad 19,020$

$715,00 \quad 19,020$

$568,50 \quad 19,020$

$572,25 \quad 19,020$

$606,75 \quad 19,020$

$718,75 \quad 19,020$ 


\begin{tabular}{|c|c|c|c|c|}
\hline A & B & C & Média & Desvio padrão \\
\hline 0 & 2 & 4 & 843,00 & 19,020 \\
\hline 0 & 3 & 0 & 582,00 & 19,020 \\
\hline 0 & 3 & 1 & 697,50 & 19,020 \\
\hline 0 & 3 & 2 & 794,00 & 19,020 \\
\hline 0 & 3 & 3 & 866,00 & 19,020 \\
\hline 0 & 3 & 4 & 1019,50 & 19,020 \\
\hline 1 & 0 & 0 & $0,00 \quad 1$ & 19,020 \\
\hline 1 & 0 & 1 & $-0,00$ & 19,020 \\
\hline 1 & 0 & 2 & $-0,00$ & 19,020 \\
\hline 1 & 0 & 3 & $-0,00$ & 19,020 \\
\hline 1 & 0 & 4 & $-0,00$ & 19,020 \\
\hline 1 & 1 & 0 & $0,00 \quad 1$ & 19,020 \\
\hline 1 & 1 & 1 & 324,00 & 19,020 \\
\hline 1 & 1 & 2 & 349,50 & 19,020 \\
\hline 1 & 1 & 3 & 475,50 & 19,020 \\
\hline 1 & 1 & 4 & 505,75 & 19,020 \\
\hline 1 & 2 & 0 & $0,00 \quad 1$ & 19,020 \\
\hline 1 & 2 & 1 & 364,00 & 19,020 \\
\hline 1 & 2 & 2 & 401,50 & 19,020 \\
\hline 1 & 2 & 3 & 532,75 & 19,020 \\
\hline 1 & 2 & 4 & 631,50 & 19,020 \\
\hline 1 & 3 & 0 & $0,00 \quad 1$ & 19,020 \\
\hline 1 & 3 & 1 & 546,00 & 19,020 \\
\hline
\end{tabular}




$\begin{array}{lllll}\text { A } & \text { B } & \text { C } & \text { Média } & \text { Desvio padrão } \\ 1 & 3 & 2 & 602,75 & 19,020 \\ 1 & 3 & 3 & 717,50 & 19,020 \\ 1 & 3 & 4 & 844,25 & 19,020\end{array}$

SOMA DOS QUADRADOS

$\begin{array}{llllll}\text { A } & 4634546 & \text { AB } & 591255 & & \\ \text { B } & 3156055 & \text { AC } & 411899 & \text { ABC } & 295368 \\ \text { C } & 2702862 & \text { BC } & 723783 & & \end{array}$

Tabela F.2 - Análise do planejamento fatorial completo dos resultados de RCS

\begin{tabular}{ccccccc}
\hline $\begin{array}{c}\text { Fonte de } \\
\text { Variação }\end{array}$ & $\begin{array}{c}\text { Graus de } \\
\text { liberdade } \\
\text { (GL) }\end{array}$ & $\begin{array}{c}\text { Soma dos } \\
\text { quadrados } \\
\text { (SQ) }\end{array}$ & $\begin{array}{c}\text { Quadrado } \\
\text { médio } \\
\text { QM=SQ/GL }\end{array}$ & $\mathbf{F}_{\text {calculado }}$ & $\mathbf{F}_{\text {teórico }}$ & significativo? \\
\hline A & 1 & 4634546 & 4634546 & 3202,67 & 3,84 & Sim \\
B & 3 & 3156055 & 1052018 & 726,99 & 2,60 & Sim \\
C & 4 & 2702862 & 675715 & 466,95 & 2,37 & Sim \\
AB & 3 & 591255 & 197085 & 136,19 & 2,60 & Sim \\
AC & 4 & 411899 & 102975 & 71,16 & 2,37 & Sim \\
BC & 12 & 723783 & 60315 & 41,68 & 1,75 & Sim \\
ABC & 12 & 295368 & 24614 & 17,01 & 1,75 & \\
\hline Erro & 120 & 173651 & 1447 & & & \\
Total & 159 & 1.939 .356 & 55.410 & & & \\
\hline
\end{tabular}


Experimento fatorial para o ensaio de resistência à tração por compressão diametral

Fatores

\begin{tabular}{|c|c|c|c|c|c|}
\hline & & Níveis & & crição & Repetições $r=\mathbf{4}$ \\
\hline \multirow[t]{2}{*}{$A$} & Condição de ensaio & 2 & 0 & Sem imersão & \\
\hline & & & 1 & Com imersão & \\
\hline \multirow[t]{4}{*}{ B } & Tempo de cura & 4 & 0 & Imediato (0) & \\
\hline & & & 1 & 3 dias & \\
\hline & & & 2 & 7 dias & \\
\hline & & & 3 & 28 dias & \\
\hline \multirow[t]{6}{*}{ C } & Teor de cal & 5 & 0 & $0 \%$ & \\
\hline & & & 1 & $3 \%$ & \\
\hline & & & 2 & $5 \%$ & \\
\hline & & & 3 & $7 \%$ & \\
\hline & & & 4 & $10 \%$ & \\
\hline & & 40 & & & \\
\hline
\end{tabular}


Tabela F.3 - Análise do planejamento fatorial completo dos resultados de RCD

\begin{tabular}{|c|c|c|c|c|c|c|c|c|c|c|}
\hline \multirow[b]{3}{*}{$\begin{array}{l}\text { Cond. } \\
\text { Exp. }\end{array}$} & \multirow[b]{3}{*}{$\begin{array}{l}\text { (A) } \\
\text { Cond. } \\
\text { Ensaio }\end{array}$} & \multirow[b]{3}{*}{$\begin{array}{l}\text { (B) } \\
\text { Tc }\end{array}$} & \multirow[b]{3}{*}{$\begin{array}{c}\text { (C) } \% \\
\text { cal }\end{array}$} & \multicolumn{4}{|c|}{ RCD } & \multirow{3}{*}{$\begin{array}{l}\text { Total } \\
\text { parcial. } \\
\mathbf{T}_{(\mathrm{c})}\end{array}$} & \multirow{3}{*}{$T c / r$} & \multirow{3}{*}{$\sum_{k=1}^{r} y_{k}^{2}$} \\
\hline & & & & \multicolumn{4}{|c|}{ Repetições } & & & \\
\hline & & & & y1 & y2 & y3 & y4 & & & \\
\hline 1 & 0 & 0 & 0 & 29 & 29 & 29 & 29 & 115,77 & 28,9425 & 3350,7345 \\
\hline 2 & 1 & 0 & 0 & 30 & 29 & 24 & 36 & 118,59 & 29,6475 & 3584,8599 \\
\hline 3 & 0 & 1 & 0 & 34 & 29 & 32 & 34 & 129,5 & 32,375 & 4211,9604 \\
\hline 4 & 1 & 1 & 0 & 35 & 37 & 40 & 40 & 151,46 & 37,865 & 5754,8244 \\
\hline 5 & 0 & 2 & 0 & 40 & 45 & 46 & 43 & 174,7 & 43,675 & 7651,3606 \\
\hline 6 & 1 & 2 & 0 & 38 & 35 & 40 & 40 & 153,57 & 38,3925 & 5915,8715 \\
\hline 7 & 0 & 3 & 0 & 41 & 41 & 40 & 42 & 163,77 & 40,9425 & 6707,6621 \\
\hline 8 & 1 & 3 & 0 & 46 & 40 & 40 & 43 & 169,09 & 42,2725 & 7170,3939 \\
\hline 9 & 0 & 0 & 1 & 47 & 46 & 46 & 46 & 183,51 & 45,8775 & 8419,4967 \\
\hline 10 & 1 & 0 & 1 & 55 & 57 & 51 & 57 & 220,32 & 55,08 & 12156,679 \\
\hline 11 & 0 & 1 & 1 & 46 & 41 & 39 & 40 & 165,9 & 41,475 & 6916,6314 \\
\hline 12 & 1 & 1 & 1 & 46 & 52 & 52 & 40 & 189,89 & 47,4725 & 9114,8097 \\
\hline 13 & 0 & 2 & 1 & 49 & 57 & 57 & 49 & 210,51 & 52,6275 & 11146,211 \\
\hline 14 & 1 & 2 & 1 & 66 & 58 & 54 & 57 & 235,07 & 58,7675 & 13888,711 \\
\hline 15 & 0 & 3 & 1 & 69 & 63 & 63 & 57 & 251,31 & 62,8275 & 15855,914 \\
\hline 16 & 1 & 3 & 1 & 58 & 52 & 46 & 49 & 206,04 & 51,51 & 10692,908 \\
\hline 17 & 0 & 0 & 2 & 77 & 74 & 71 & 65 & 286,68 & 71,67 & 20620,862 \\
\hline 18 & 1 & 0 & 2 & 83 & 82 & 82 & 82 & 328,99 & 82,2475 & 27058,930 \\
\hline 19 & 0 & 1 & 2 & 94 & 85 & 97 & 94 & 368,73 & 92,1825 & 34069,398 \\
\hline 20 & 1 & 1 & 2 & 108 & 113 & 112 & 114 & 446,78 & 111,695 & 49926,726 \\
\hline 21 & 0 & 2 & 2 & 0 & 0 & 0 & 0 & 0 & 0 & 0 \\
\hline 22 & 1 & 2 & 2 & 0 & 0 & 0 & 0 & 0 & 0 & 0 \\
\hline 23 & 0 & 3 & 2 & 0 & 0 & 0 & 0 & 0 & 0 & 0 \\
\hline 24 & 1 & 3 & 2 & 0 & 0 & 0 & 0 & 0 & 0 & 0 \\
\hline 25 & 0 & 0 & 3 & 0 & 0 & 0 & 0 & 0 & 0 & 0 \\
\hline 26 & 1 & 0 & 3 & 0 & 0 & 0 & 0 & 0 & 0 & 0 \\
\hline 27 & 0 & 1 & 3 & 28 & 28 & 29 & 17 & 102,82 & 25,705 & 2741,3678 \\
\hline 28 & 1 & 1 & 3 & 29 & 24 & 29 & 29 & 110,5 & 27,625 & 3073,1634 \\
\hline 29 & 0 & 2 & 3 & 34 & 35 & 34 & 34 & 137,21 & 34,3025 & 4706,7773 \\
\hline 30 & 1 & 2 & 3 & 46 & 46 & 45 & 45 & 182,34 & 45,585 & 8312,1382 \\
\hline 31 & 0 & 3 & 3 & 0 & 0 & 0 & 0 & 0 & 0 & 0 \\
\hline 32 & 1 & 3 & 3 & 35 & 29 & 29 & 32 & 124,21 & 31,0525 & 3883,7819 \\
\hline 33 & 0 & 0 & 4 & 31 & 29 & 32 & 33 & 126,31 & 31,5775 & 3998,9873 \\
\hline 34 & 1 & 0 & 4 & 35 & 35 & 29 & 40 & 137,66 & 34,415 & 4801,3204 \\
\hline 35 & 0 & 1 & 4 & 51 & 51 & 51 & 51 & 204,82 & 51,205 & 10487,8356 \\
\hline 36 & 1 & 1 & 4 & 0 & 0 & 0 & 0 & 0 & 0 & 0 \\
\hline 37 & 0 & 2 & 4 & 57 & 56 & 62 & 59 & 234,37 & 58,5925 & 13753,2557 \\
\hline 38 & 1 & 2 & 4 & 65 & 71 & 66 & 69 & 271,26 & 67,815 & 18417,577 \\
\hline 39 & 0 & 3 & 4 & 69 & 74 & 80 & 71 & 293,95 & 73,4875 & 21670,367 \\
\hline 40 & 1 & 3 & 4 & 83 & 82 & 85 & 94 & 344,48 & 86,12 & 29755,259 \\
\hline & & & & & & & otal & 6540,11 & 1635,028 & 389816,78 \\
\hline
\end{tabular}

$$
C=\frac{T^{2}}{N}=267331,492576 \quad S Q_{\text {total }}=\sum_{c=1}^{m} \sum_{k=1}^{r} y_{c k}^{2}-\frac{T^{2}}{N}=122485,287424
$$




$\begin{array}{lll}\text { A } & \text { Média } & \text { Desvio } \\ 0 & 53,425 & 0,3583 \\ 1 & 28,350 & 0,3583 \\ \text { B } & & \\ 0 & 17,250 & 0,5068 \\ 1 & 35,575 & 0,5068 \\ 2 & 41,200 & 0,5068 \\ 3 & 69,525 & 0,5068 \\ \text { C } & & \\ 0 & 20,000 & 0,5666 \\ 1 & 38,156 & 0,5666 \\ 2 & 42,063 & 0,5666 \\ 3 & 47,250 & 0,5666 \\ 4 & 56,969 & 0,5666\end{array}$

AB

$\begin{array}{llll}0 & 0 & 34,500 & 0,7167 \\ 0 & 1 & 44,550 & 0,7167 \\ 0 & 2 & 52,750 & 0,7167 \\ 0 & 3 & 81,900 & 0,7167 \\ 1 & 0 & 0,000 & 0,7167 \\ 1 & 1 & 26,600 & 0,7167 \\ 1 & 2 & 29,650 & 0,7167 \\ \text { A } & \text { C } & \text { Média } & \text { Desvio padrão } \\ 1 & 3 & 57,150 & 0,7167 \\ 0 & 0 & 40,000 & 0,8013 \\ 0 & 1 & 47,500 & 0,8013\end{array}$




\begin{tabular}{|c|c|c|c|}
\hline 0 & 2 & 52,438 & 0,8013 \\
\hline 0 & 3 & 58,875 & 0,8013 \\
\hline 0 & 4 & 68,313 & 0,8013 \\
\hline 1 & 0 & $-0,000$ & 0,8013 \\
\hline 1 & 1 & 28,812 & 0,8013 \\
\hline 1 & 2 & 31,688 & 0,8013 \\
\hline 1 & 3 & 35,625 & 0,8013 \\
\hline 1 & 4 & 45,625 & 0,8013 \\
\hline B & C & & \\
\hline 0 & 0 & 14,500 & 1,1332 \\
\hline 0 & 1 & 14,875 & 1,1332 \\
\hline 0 & 2 & 16,125 & 1,1332 \\
\hline 0 & 3 & 19,000 & 1,1332 \\
\hline 0 & 4 & 21,750 & 1,1332 \\
\hline 1 & 0 & 19,125 & 1,1332 \\
\hline 1 & 1 & 33,250 & 1,1332 \\
\hline 1 & 2 & 35,000 & 1,1332 \\
\hline 1 & 3 & 40,250 & 1,1332 \\
\hline 1 & 4 & 50,250 & 1,1332 \\
\hline
\end{tabular}

A C

20

21

22

23

24
Média Desvio padrão

$20,750 \quad 1,1332$

$39,375 \quad 1,1332$

$42,125 \quad 1,1332$

$46,750 \quad 1,1332$

$57,000 \quad 1,1332$ 


\begin{tabular}{|c|c|c|c|c|}
\hline 3 & 0 & & 25,625 & 1,1332 \\
\hline 3 & 1 & & 65,125 & 1,1332 \\
\hline 3 & 2 & & 75,000 & 1,1332 \\
\hline 3 & 3 & & 83,000 & 1,1332 \\
\hline 3 & 4 & & 98,875 & 1,1332 \\
\hline $\mathbf{A}$ & B & C & & \\
\hline 0 & 0 & 0 & 29,000 & 1,6025 \\
\hline 0 & 0 & 1 & 29,750 & 1,6025 \\
\hline 0 & 0 & 2 & 32,250 & 1,6025 \\
\hline 0 & 0 & 3 & 38,000 & 1,6025 \\
\hline 0 & 0 & 4 & 43,500 & 1,6025 \\
\hline 0 & 1 & 0 & 38,250 & 1,6025 \\
\hline 0 & 1 & 1 & 41,000 & 1,6025 \\
\hline 0 & 1 & 2 & 42,250 & 1,6025 \\
\hline 0 & 1 & 3 & 46,250 & 1,6025 \\
\hline 0 & 1 & 4 & 55,000 & 1,6025 \\
\hline 0 & 2 & 0 & 41,500 & 1,6025 \\
\hline 0 & 2 & 1 & 47,500 & 1,6025 \\
\hline A & B & C & Média & Desvio padrão \\
\hline 0 & 2 & 2 & 53,000 & 1,6025 \\
\hline 0 & 2 & 3 & 58,750 & 1,6025 \\
\hline 0 & 2 & 4 & 63,000 & 1,6025 \\
\hline 0 & 3 & 0 & 51,250 & 1,6025 \\
\hline 0 & 3 & 1 & 71,750 & 1,6025 \\
\hline 0 & 3 & 2 & 82,250 & 1,6025 \\
\hline 0 & 3 & 3 & 92,500 & 1,6025 \\
\hline
\end{tabular}




\begin{tabular}{|c|c|c|c|c|}
\hline 0 & 3 & 4 & 111,750 & 1,6025 \\
\hline 1 & 0 & 0 & $-0,000$ & 1,6025 \\
\hline 1 & 0 & 1 & $-0,000$ & 1,6025 \\
\hline 1 & 0 & 2 & 0,000 & 1,6025 \\
\hline 1 & 0 & 3 & 0,000 & 1,6025 \\
\hline 1 & 0 & 4 & 0,000 & 1,6025 \\
\hline 1 & 1 & 0 & $-0,000$ & 1,6025 \\
\hline 1 & 1 & 1 & 25,500 & 1,6025 \\
\hline 1 & 1 & 2 & 27,750 & 1,6025 \\
\hline 1 & 1 & 3 & 34,250 & 1,6025 \\
\hline 1 & 1 & 4 & 45,500 & 1,6025 \\
\hline 1 & 2 & 0 & $-0,000$ & 1,6025 \\
\hline 1 & 2 & 1 & 31,250 & 1,6025 \\
\hline 1 & 2 & 2 & 31,250 & 1,6025 \\
\hline 1 & 2 & 3 & 34,750 & 1,6025 \\
\hline 1 & 2 & 4 & 51,000 & 1,6025 \\
\hline A & B & C & Média & Dévio padrão \\
\hline 1 & 3 & 0 & 0,000 & 1,6025 \\
\hline 1 & 3 & 1 & 58,500 & 1,6025 \\
\hline 1 & 3 & 2 & 67,750 & 1,6025 \\
\hline 1 & 3 & 3 & 73,500 & 1,6025 \\
\hline
\end{tabular}

SOMA DOS QUADRADOS
A $\quad 25150$
AB $\quad 1436$
B $\quad 56286$
AC $\quad 2330$
ABC 2015
C $\quad 23815$
BC 10375 
Tabela F.4 - Influência das variáveis do estudo sobre a resistência à tração por compressão diametral

\begin{tabular}{ccccccc}
\hline $\begin{array}{c}\text { Fonte de } \\
\text { Variação }\end{array}$ & $\begin{array}{c}\text { Graus de } \\
\text { liberdade } \\
\text { (GL) }\end{array}$ & $\begin{array}{c}\text { Soma dos } \\
\text { quadrados } \\
(\mathbf{S Q})\end{array}$ & $\begin{array}{c}\text { Quadrado } \\
\text { médio } \\
\mathbf{Q}=\mathbf{S Q} \text { /GL }\end{array}$ & $\mathbf{F}_{\text {calculado }}$ & $\mathbf{F}_{\text {teórico }}$ & significativo? \\
\hline A & 1 & 25150 & 25150 & 2448 & 3,84 & sim \\
B & 3 & 56286 & 18762 & 1826 & 2,60 & sim \\
C & 4 & 23815 & 5953 & 579,58 & 2,37 & sim \\
AB & 3 & 1436 & 479 & 46,60 & 2,60 & sim \\
AC & 4 & 2330 & 583 & 56,71 & 2,37 & sim \\
BC & 12 & 10375 & 864 & 84,16 & 1,75 & sim \\
ABC & 12 & 2015 & 168 & 16,35 & 1,75 & \\
\hline Erro & 117 & 1202 & 10,3 & & & \\
Total & 159 & 122622 & & & & \\
\hline
\end{tabular}


Experimento fatorial para as análises do módulo tangente inicial $\left(E_{0}\right)$

Fatores

\begin{tabular}{|c|c|c|c|c|c|}
\hline & & Níveis & & crição & Repetições $r=\mathbf{4}$ \\
\hline \multirow[t]{2}{*}{$A$} & Condição de ensaio & 2 & 0 & Sem imersão & \\
\hline & & & 1 & Com imersão & \\
\hline \multirow[t]{4}{*}{ B } & Tempo de cura & 4 & 0 & Imediato (0) & \\
\hline & & & 1 & 3 dias & \\
\hline & & & 2 & 7 dias & \\
\hline & & & 3 & 28 dias & \\
\hline \multirow[t]{6}{*}{ C } & Teor de cal & 5 & 0 & $0 \%$ & \\
\hline & & & 1 & $3 \%$ & \\
\hline & & & 2 & $5 \%$ & \\
\hline & & & 3 & $7 \%$ & \\
\hline & & & 4 & $10 \%$ & \\
\hline & & 40 & & & \\
\hline
\end{tabular}


Tabela F.4 - Análise do planejamento fatorial completo das análises do

$\left(E_{0}\right)$

\begin{tabular}{|c|c|c|c|c|c|c|c|c|c|c|}
\hline \multirow[b]{3}{*}{$\begin{array}{l}\text { Cond. } \\
\text { Exp. }\end{array}$} & \multirow[b]{3}{*}{$\begin{array}{c}\text { (A) } \\
\text { Cond. } \\
\text { Ensaio }\end{array}$} & \multirow[b]{3}{*}{$\begin{array}{l}\text { (B) } \\
\text { TC }\end{array}$} & \multirow[b]{3}{*}{$\begin{array}{l}\text { (C) } \% \\
\text { cal }\end{array}$} & \multicolumn{4}{|c|}{$E_{0}$} & \multirow{3}{*}{$\begin{array}{c}\text { Total } \\
\text { parcial. } \\
T_{(\mathrm{c})}\end{array}$} & \multirow{3}{*}{$\mathrm{Tc} / \mathrm{r}$} & \multirow{3}{*}{$\sum_{k=1}^{r} y_{k}^{2}$} \\
\hline & & & & \multicolumn{4}{|c|}{ Repetições } & & & \\
\hline & & & & y1 & y2 & y3 & y4 & & & \\
\hline 1 & 0 & 0 & 0 & 16916 & 25644 & 16789 & 15179 & 74528 & 18632 & $1,456 \mathrm{E}+09$ \\
\hline 2 & 1 & 0 & 0 & 18900 & 19785 & 17845 & 18986 & 75516 & 18879 & $1,428 \mathrm{E}+09$ \\
\hline 3 & 0 & 1 & 0 & 20402 & 18469 & 19777 & 20497 & 79145 & 19786,25 & $1,569 E+09$ \\
\hline 4 & 1 & 1 & 0 & 22954 & 22900 & 22000 & 18234 & 86088 & 21522 & $1,868 \mathrm{E}+09$ \\
\hline 5 & 0 & 2 & 0 & 25757 & 16460 & 22000 & 27881 & 92098 & 23024,5 & $2,196 \mathrm{E}+09$ \\
\hline 6 & 1 & 2 & 0 & 37347 & 38000 & 43629 & 38000 & 156976 & 39244 & $6,186 \mathrm{E}+09$ \\
\hline 7 & 0 & 3 & 0 & 21913 & 51942 & 53000 & 24897 & 151752 & 37938 & $6,607 \mathrm{E}+09$ \\
\hline 8 & 1 & 3 & 0 & 58305 & 62757 & 48057 & 49000 & 218119 & 54529,75 & $1,205 E+10$ \\
\hline 9 & 0 & 0 & 1 & 58635 & 58000 & 50552 & 53023 & 220210 & 55052,5 & $1,217 \mathrm{E}+10$ \\
\hline 10 & 1 & 0 & 1 & 55000 & 62670 & 60811 & 51376 & 229857 & 57464,25 & $1,329 \mathrm{E}+10$ \\
\hline 11 & 0 & 1 & 1 & 58311 & 64667 & 65754 & 63200 & 251932 & 62983 & $1,59 E+10$ \\
\hline 12 & 1 & 1 & 1 & 83303 & 81000 & 38327 & 64084 & 266714 & 66678,5 & $1,908 \mathrm{E}+10$ \\
\hline 13 & 0 & 2 & 1 & 71000 & 83000 & 65245 & 43482 & 262727 & 65681,75 & $1,808 \mathrm{E}+10$ \\
\hline 14 & 1 & 2 & 1 & 80000 & 70275 & 84000 & 65000 & 299275 & 74818,75 & $2,262 \mathrm{E}+10$ \\
\hline 15 & 0 & 3 & 1 & 81000 & 100333 & 81000 & 85522 & 347855 & 86963,75 & $3,05 E+10$ \\
\hline 16 & 1 & 3 & 1 & 20910 & 37744 & 35902 & 49000 & 143556 & 35889 & $5,552 \mathrm{E}+09$ \\
\hline 17 & 0 & 0 & 2 & 76279 & 85000 & 55882 & 89096 & 306257 & 76564,25 & $2,41 E+10$ \\
\hline 18 & 1 & 0 & 2 & 88000 & 86917 & 90228 & 64677 & 329822 & 82455,5 & $2,762 \mathrm{E}+10$ \\
\hline 19 & 0 & 1 & 2 & 110378 & 100616 & 88000 & 100000 & 398994 & 99748,5 & $4,005 E+10$ \\
\hline 20 & 1 & 1 & 2 & 59000 & 108000 & 102000 & 115000 & 384000 & 96000 & $3,877 \mathrm{E}+10$ \\
\hline 21 & 0 & 2 & 2 & 0 & 0 & 0 & 0 & 0 & 0 & 0 \\
\hline 22 & 1 & 2 & 2 & 0 & 0 & 0 & 0 & 0 & 0 & 0 \\
\hline 23 & 0 & 3 & 2 & 0 & 0 & 0 & 0 & 0 & 0 & 0 \\
\hline 24 & 1 & 3 & 2 & 0 & 0 & 0 & 0 & 0 & 0 & 0 \\
\hline 25 & 0 & 0 & 3 & 0 & 0 & 0 & 0 & 0 & 0 & 0 \\
\hline 26 & 1 & 0 & 3 & 0 & 0 & 0 & 0 & 0 & 0 & 0 \\
\hline 27 & 0 & 1 & 3 & 34819 & 18006 & 12000 & 7299 & 72124 & 18031 & $1,734 \mathrm{E}+09$ \\
\hline 28 & 1 & 1 & 3 & 35000 & 22233 & 25503 & 27403 & 110139 & 27534,75 & $3,121 \mathrm{E}+09$ \\
\hline 29 & 0 & 2 & 3 & 41180 & 30743 & 55000 & 31000 & 157923 & 39480,75 & $6,627 \mathrm{E}+09$ \\
\hline 30 & 1 & 2 & 3 & 55087 & 45000 & 38888 & 14249 & 153224 & 38306 & $6,775 E+09$ \\
\hline 31 & 0 & 3 & 3 & 0 & 0 & 0 & 0 & 0 & 0 & 0 \\
\hline 32 & 1 & 3 & 3 & 37130 & 40000 & 33348 & 29000 & 139478 & 34869,5 & $4,932 E+09$ \\
\hline 33 & 0 & 0 & 4 & 49777 & 51000 & 55237 & 43482 & 199496 & 49874 & $1,002 E+10$ \\
\hline 34 & 1 & 0 & 4 & 47000 & 17973 & 54173 & 104143 & 223289 & 55822,25 & $1,631 \mathrm{E}+10$ \\
\hline 35 & 0 & 1 & 4 & 75433 & 74358 & 79953 & 75000 & 304744 & 76186 & $2,324 \mathrm{E}+10$ \\
\hline 36 & 1 & 1 & 4 & 0 & 0 & 0 & 0 & 0 & 0 & 0 \\
\hline 37 & 0 & 2 & 4 & 71000 & 72749 & 86147 & 77842 & 307738 & 76934,5 & $2,381 E+10$ \\
\hline 38 & 1 & 2 & 4 & 236358 & 82402 & 82000 & 146884 & 547644 & 136911 & $9,095 E+10$ \\
\hline 39 & 0 & 3 & 4 & 102759 & 62095 & 92064 & 98000 & 354918 & 88729,5 & $3,249 E+10$ \\
\hline 40 & 1 & 3 & 4 & 101000 & 113000 & 59918 & 115248 & 389166 & 97291,5 & $3,984 \mathrm{E}+10$ \\
\hline & & & & & & & Total & 7335304 & 1833826 & $5,61 \mathrm{E}+11$ \\
\hline
\end{tabular}




$$
C=\frac{T^{2}}{N}=336291779828 \quad S Q_{\text {total }}=\sum_{c=1}^{m} \sum_{k=1}^{r} y_{c k}^{2}-\frac{T^{2}}{N}=224708220172
$$

A

0

1

B

0

1

2

3

C

0

1

2

3

4

A B

$0 \quad 0$

$0 \quad 1$

02

03

10

11

12

13

\section{Média Desvio padrão}

$54693 \quad 1840$

$36999 \quad 1840$

101842603

$36758 \quad 2603$

$57388 \quad 2603$

$79052 \quad 2603$

$19594 \quad 2910$

$41237 \quad 2910$

$54597 \quad 2910$

$54397 \quad 2910$

$59404 \quad 2910$

B

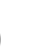

203693681

$48846 \quad 3681$

$71425 \quad 3681$

$78131 \quad 3681$

$0 \quad 3681$

$24671 \quad 3681$

$43350 \quad 3681$

$79973 \quad 3681$ 
A C

$0 \quad 0$

$39187 \quad 4115$

$0 \quad 1$

$50015 \quad 4115$

02

$55613 \quad 4115$

03

$62785 \quad 4115$

04

$65863 \quad 4115$

10

$0 \quad 4115$

11

$32459 \quad 4115$

12

$53580 \quad 4115$

13

$46008 \quad 4115$

14

$52946 \quad 4115$

B C

$0 \quad 0$

$9316 \quad 5820$

$0 \quad 1$

$9439 \quad 5820$

02

$9893 \quad 5820$

03

107615820

04

$11512 \quad 5820$

10

$19622 \quad 5820$

11

$27984 \quad 5820$

12

$41032 \quad 5820$

13

$47267 \quad 5820$

14

$47885 \quad 5820$

20

$31491 \quad 5820$

21

$50774 \quad 5820$

22

$57778 \quad 5820$

23

$65320 \quad 5820$ 


\begin{tabular}{|c|c|c|c|c|}
\hline B & C & & Média & Desvio padrão \\
\hline 2 & 4 & & 81575 & 5820 \\
\hline 3 & 0 & & 17945 & 5820 \\
\hline 3 & 1 & & 76749 & 5820 \\
\hline 3 & 2 & & 109683 & 5820 \\
\hline 3 & 4 & & 94239 & 5820 \\
\hline 3 & 5 & & 96646 & 5820 \\
\hline A & B & C & & \\
\hline 0 & 0 & 1 & 18632 & 8230 \\
\hline 0 & 0 & 2 & 18879 & 8230 \\
\hline 0 & 0 & 3 & 19786 & 8230 \\
\hline 0 & 0 & 4 & 21522 & 8230 \\
\hline 0 & 0 & 5 & 23025 & 8230 \\
\hline 0 & 1 & 1 & 39244 & 8230 \\
\hline 0 & 1 & 2 & 37938 & 8230 \\
\hline 0 & 1 & 3 & 54530 & 8230 \\
\hline 0 & 1 & 4 & 55052 & 8230 \\
\hline 0 & 1 & 5 & 57464 & 8230 \\
\hline 0 & 2 & 1 & 62983 & 8230 \\
\hline 0 & 2 & 2 & 66678 & 8230 \\
\hline 0 & 2 & 3 & 65682 & 8230 \\
\hline 0 & 2 & 4 & 74819 & 8230 \\
\hline 0 & 2 & 5 & 86964 & 8230 \\
\hline 0 & 3 & 1 & 35889 & 8230 \\
\hline 0 & 3 & 2 & 76564 & 8230 \\
\hline 0 & 3 & 3 & 82455 & 8230 \\
\hline
\end{tabular}


A B C Média Desvio padrão

$\begin{array}{lllll}0 & 3 & 4 & 99749 & 8230\end{array}$

$\begin{array}{lllll}0 & 3 & 5 & 96000 & 8230\end{array}$

$\begin{array}{lllll}1 & 0 & 1 & 0 & 8230\end{array}$

$\begin{array}{lllll}1 & 0 & 2 & 0 & 8230\end{array}$

$\begin{array}{lllll}1 & 0 & 3 & 0 & 8230\end{array}$

$\begin{array}{lllll}1 & 0 & 4 & -0 & 8230\end{array}$

$\begin{array}{lllll}1 & 0 & 5 & -0 & 8230\end{array}$

$\begin{array}{lllll}1 & 1 & 1 & 0 & 8230\end{array}$

$\begin{array}{lllll}1 & 1 & 2 & 18031 & 8230\end{array}$

$\begin{array}{lllll}1 & 1 & 3 & 27535 & 8230\end{array}$

$\begin{array}{lllll}1 & 1 & 4 & 39481 & 8230\end{array}$

$\begin{array}{lllll}1 & 1 & 5 & 38306 & 8230\end{array}$

$\begin{array}{lllll}1 & 2 & 1 & 0 & 8230\end{array}$

$\begin{array}{lllll}1 & 2 & 2 & 34869 & 8230\end{array}$

$\begin{array}{lllll}1 & 2 & 3 & 49874 & 8230\end{array}$

$\begin{array}{lllll}1 & 2 & 4 & 55822 & 8230\end{array}$

$\begin{array}{lllll}1 & 2 & 5 & 76186 & 8230\end{array}$

$\begin{array}{lllll}1 & 3 & 1 & 0 & 8230\end{array}$

$\begin{array}{lllll}1 & 3 & 2 & 76935 & 8230\end{array}$

$\begin{array}{lllll}1 & 3 & 3 & 136911 & 8230\end{array}$

$\begin{array}{lllll}1 & 3 & 4 & 88730 & 8230\end{array}$

$\begin{array}{lllll}1 & 3 & 5 & 97291 & 8230\end{array}$ 


\section{SOMA DOS QUADRADOS}

$\begin{array}{llllll}\text { A } & 1,2523 E+10 & \text { AB } & 5385706847 & & \\ \text { B } & 1,0361 E+11 & \text { AC } & 2330 & \text { ABC } & 7134309928 \\ \text { C } & 3,3407 E+10 & \text { BC } & 2,4249 E+10 & & \end{array}$

Tabela F.5 - Análise do planejamento fatorial completo das análises do $\left(E_{0}\right)$

\begin{tabular}{|c|c|c|c|c|c|c|}
\hline $\begin{array}{l}\text { Fonte de } \\
\text { Variação }\end{array}$ & $\begin{array}{c}\text { Graus de } \\
\text { liberdade } \\
\text { (GL) } \\
\end{array}$ & $\begin{array}{c}\text { Soma dos } \\
\text { quadrados } \\
\text { (SQ) }\end{array}$ & $\begin{array}{c}\text { Quadrado } \\
\text { médio } \\
\text { QM=SQ/GL }\end{array}$ & $F_{\text {calculado }}$ & $F_{\text {teórico }}$ & significativo? \\
\hline A & 1 & $1,2523 E+10$ & $1,2523 E+10$ & 46,22 & 4,84 & $\operatorname{sim}$ \\
\hline B & 3 & 1,0361E+11 & $3,4536 E+10$ & 127,47 & 4,84 & $\operatorname{sim}$ \\
\hline C & 4 & 3,3407E+10 & 835168237 & 6,63 & 3,98 & $\operatorname{sim}$ \\
\hline$A B$ & 3 & 5385706847 & 1795235616 & 5,40 & 4,84 & não \\
\hline$A C$ & 4 & 5847046984 & 1461761746 & 7,46 & 3,98 & $\operatorname{sim}$ \\
\hline $\mathrm{BC}$ & 12 & $2,4249 E+10$ & 2020747155 & 2,19 & 3,98 & não \\
\hline$A B C$ & 12 & 7134309928 & 594525827 & & & \\
\hline Erro & 120 & $3,2513 E+10$ & 270938982 & & & \\
\hline Total & 159 & $2,2467 E+11$ & & & & \\
\hline
\end{tabular}




\section{Experimento fatorial para o ensaio de CBR}

Fatores

Níveis

1

5

B Teor de cal

$\begin{array}{cccc} & \text { Níveis } & \text { Descrição } & \text { Repetições } r=1 \\ & 1 & 0 & \text { Sem imersão } \\ & 0 & 0 \% \\ & 1 & 3 \% \\ & 2 & 5 \% \\ & 3 & 10 \%\end{array}$

Tabela F.4 - Análise do planejamento fatorial completo das análises do $\left(E_{0}\right)$

\begin{tabular}{|c|c|c|c|c|c|c|c|c|c|c|}
\hline \multirow[b]{3}{*}{$\begin{array}{l}\text { Cond. } \\
\text { Exp. }\end{array}$} & & & \multicolumn{5}{|c|}{ CBR } & \multirow{3}{*}{$\begin{array}{c}\text { Total } \\
\text { parcial. } \\
\mathbf{T}_{(\mathrm{c})}\end{array}$} & \multirow{3}{*}{$\mathrm{Tc} / \mathrm{r}$} & \multirow[b]{3}{*}{$\sum_{k=1}^{r} y_{k}^{2}$} \\
\hline & & & & \multicolumn{4}{|c|}{ Repetições } & & & \\
\hline & \multicolumn{2}{|r|}{$\begin{array}{c}\text { (A) } \\
\text { Cond. } \\
\text { Ensaio }\end{array}$} & $\begin{array}{c}\text { (C) } \% \\
\text { cal }\end{array}$ & y1 & y2 & y3 & y4 & & & \\
\hline & 0 & 0 & 0 & 16 & & & & 16 & 16 & 256 \\
\hline & 0 & 1 & 0 & 54 & & & & 54 & 54 & 2916 \\
\hline & 0 & 2 & 0 & 56 & & & & 56 & 56 & 3136 \\
\hline & 0 & 3 & 0 & 65 & & & & 65 & 65 & 4225 \\
\hline & 0 & 4 & 0 & 71 & & & & 71 & 71 & 5041 \\
\hline & & & & & & & Tota & 262 & 262 & 15574 \\
\hline
\end{tabular}


- ANEXO G -

Envoltória de resistência de Mohr-

Coulomb 
Tempo de cura imediato sem imersẫo

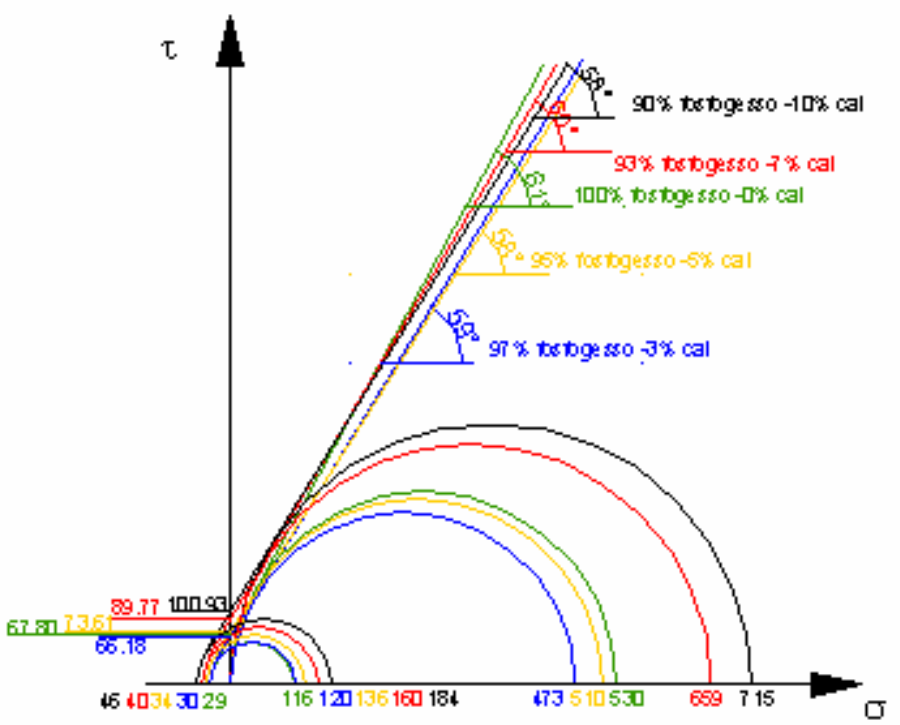

3 dias de cura - sem imersẫo

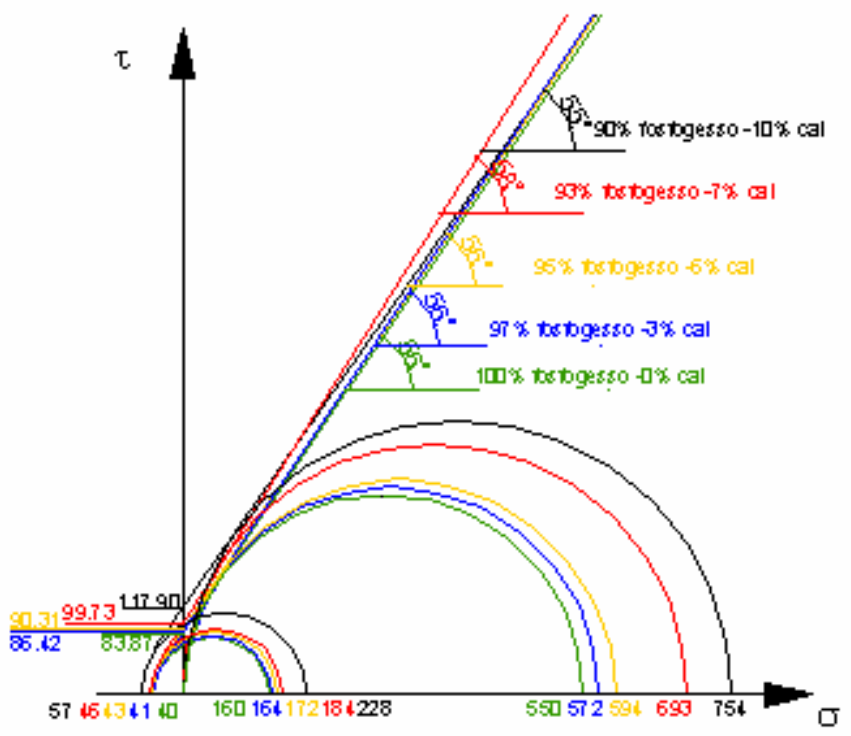


7 dias de cura - sem imersã̃o

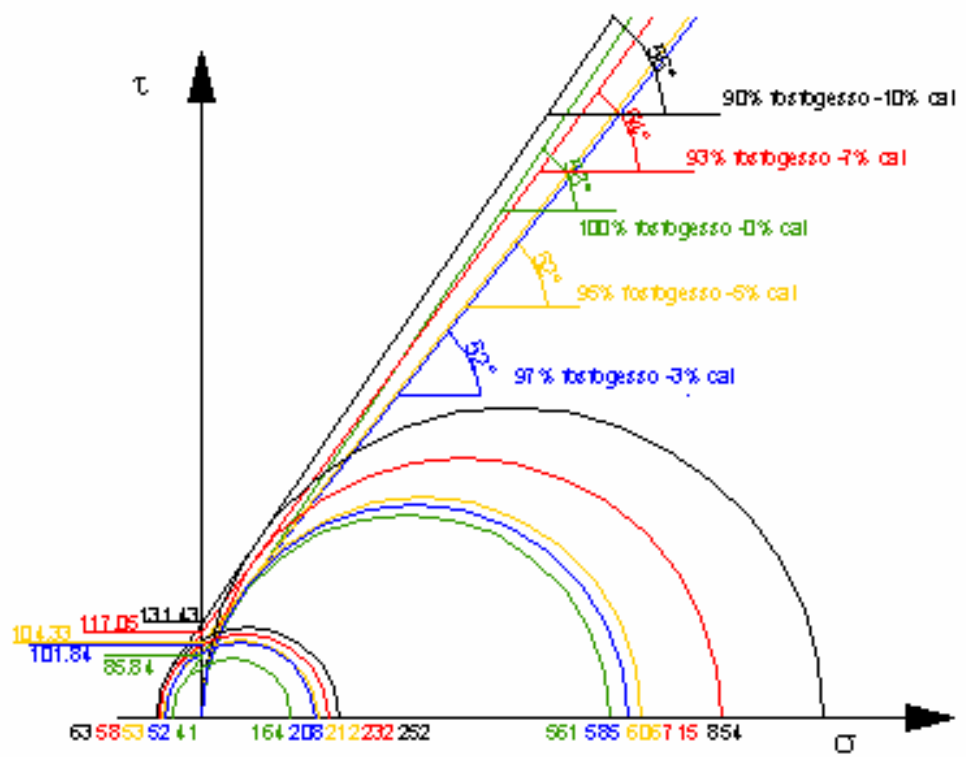

28 dias de cura - sem imersẫo

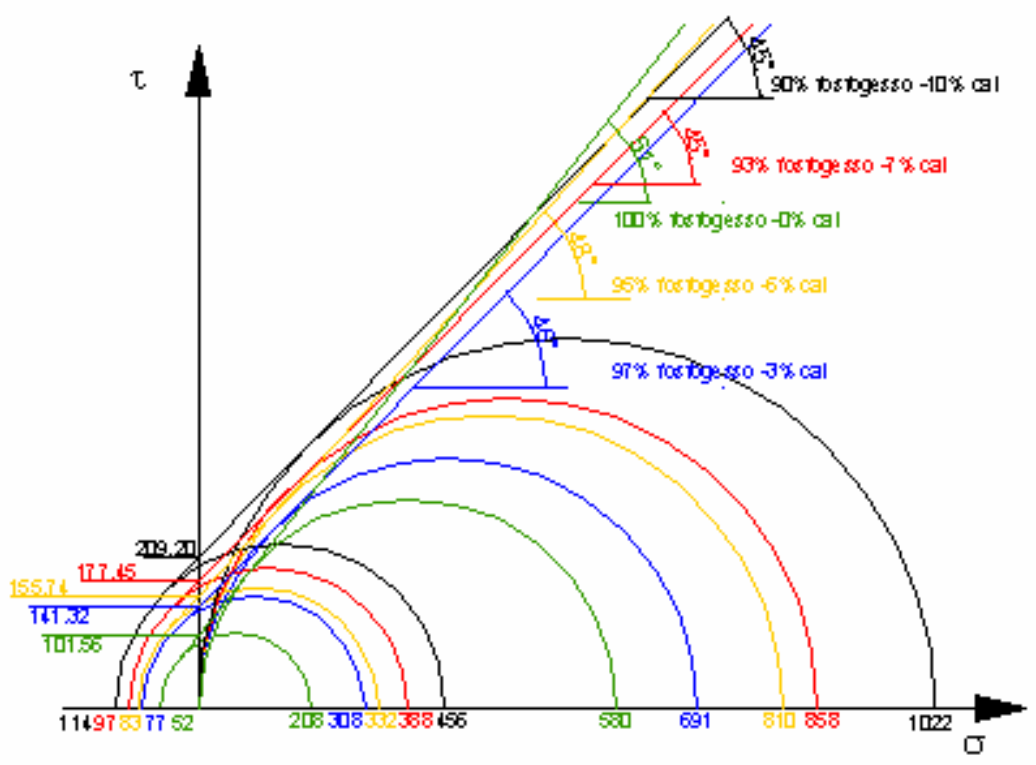


3 dias de cura - com imersẵo

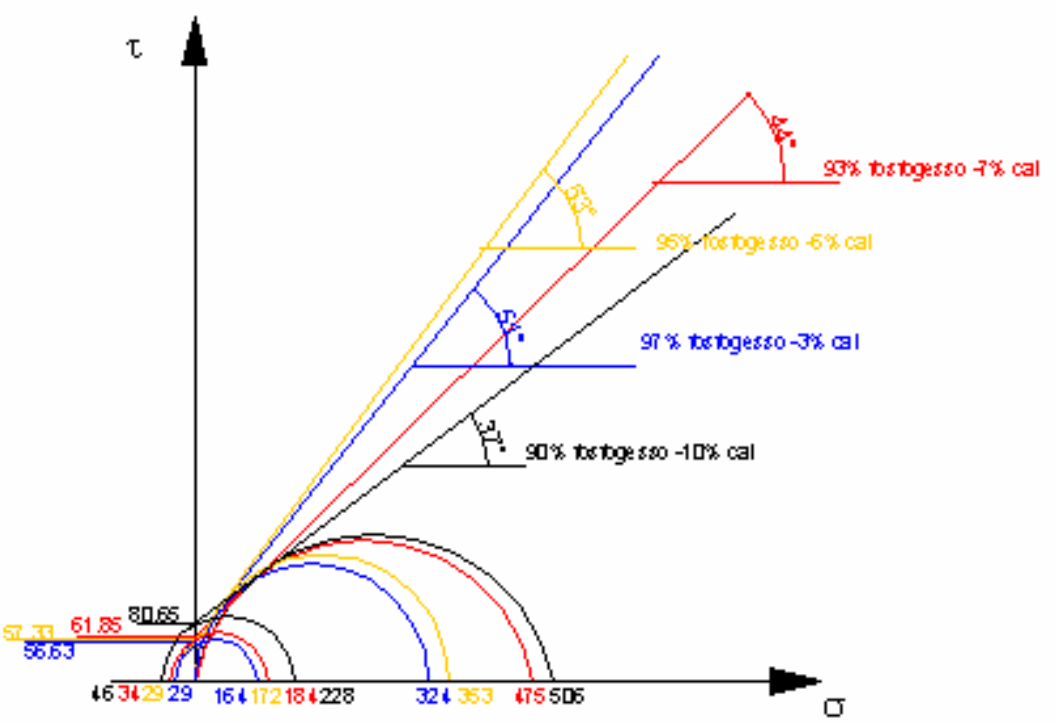

7 dias de cura - com imersẫo

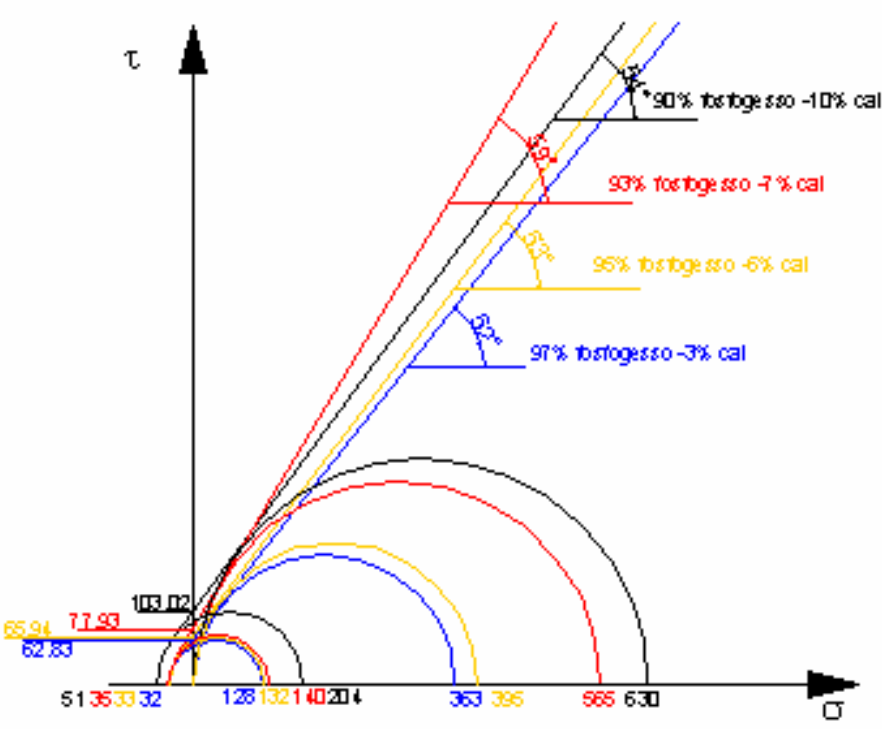


28 dias de cura - com imersẫo

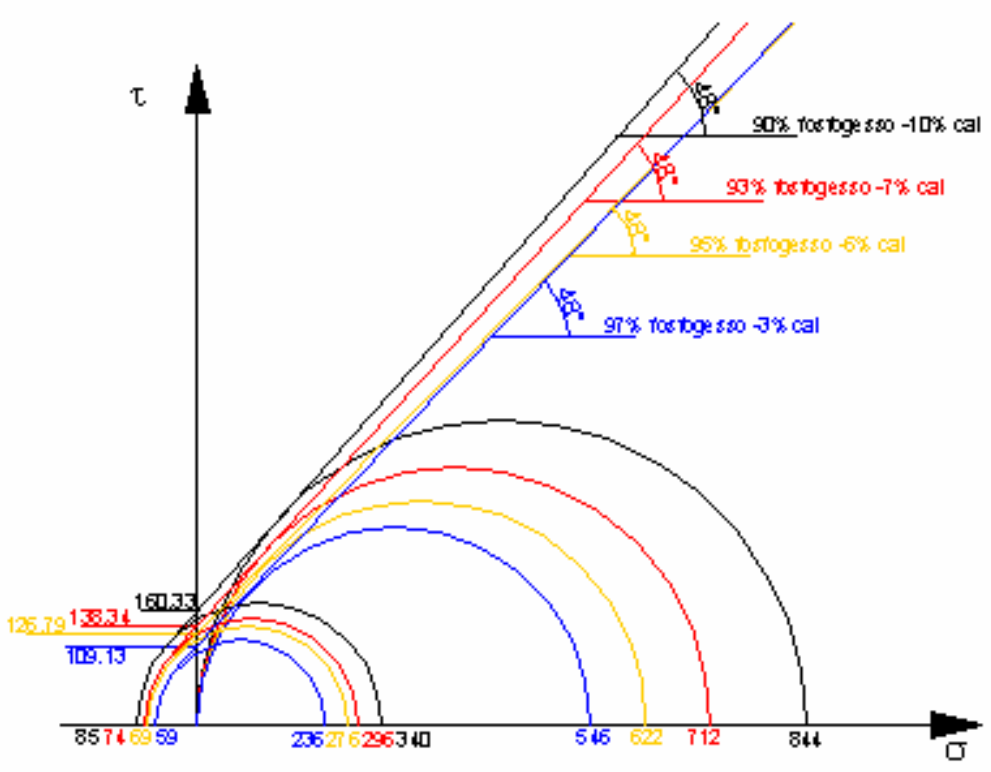

